\title{
THE STORY OF
}

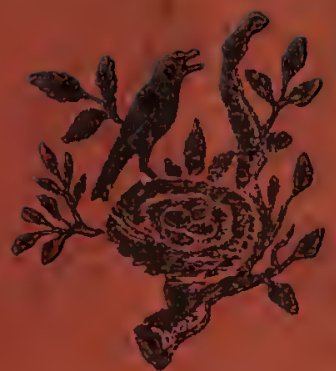

\section{OUR Museum}

AND

WHAT IT TAUGHT US
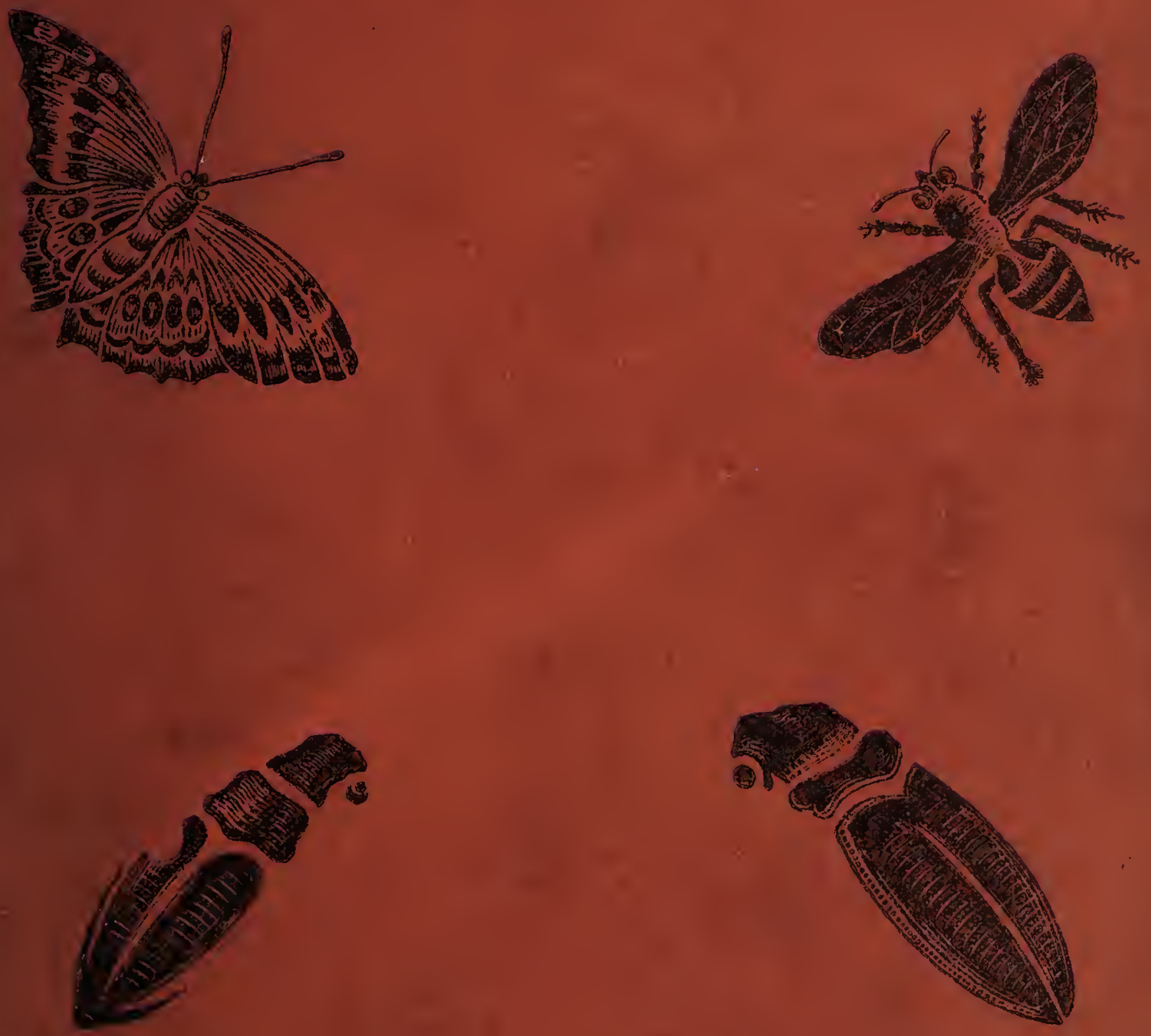


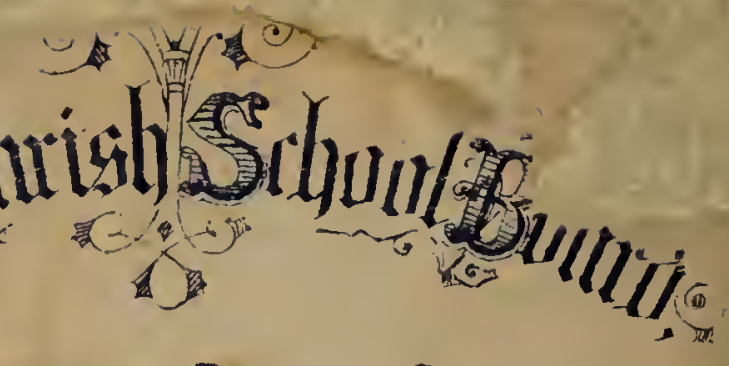

evace di: Publi School.

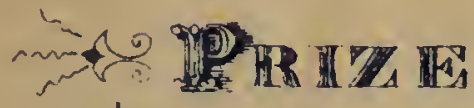

空

is ma Suide

ior

ch fidesum m d H $\Rightarrow d$ Master or

forw. It. ie 
<smiles>C1CC1</smiles> 

STORY OF OUR MUSEUM.

THE
STORY OF OUR MUSEUM.$$
\text { OUR MUSEUM. }
$$

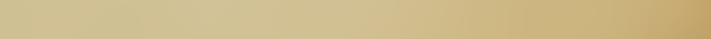

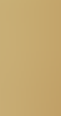

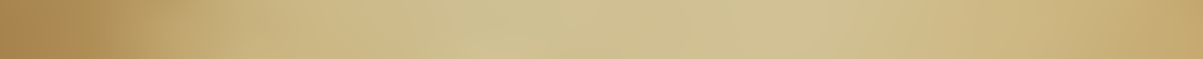

STORY OF OUI

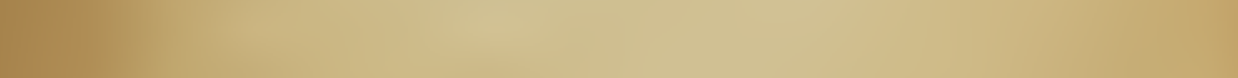

(5) 



\title{
THE STORY OF \\ OUR MUSEUM:
}

SHOWING

HOW WE FORMED IT, AND

WHAT IT TAUGHT US.

\author{
BY THE \\ REV. HENRY HOUSMAN, A.K.C., \\ LATE FELLOW OF THE GEOLOGical SOCIETy. MEMBER OF THE \\ CHICHESTER AND WEST SUSSEX NATURAL HISTORY \\ AND MICROSCOPICAL SOCIETY.
}

PUBLISHED UNDER THE DIRECTION OF THE COMMITTEE OF GENERAL LITERATURE AND EDUCATION APPOINTED BY THE SOCIETY FOR PROMOTING CHRISTIAN KNOWLEDGE.

\section{O N D O N :}

SOCIETY FOR PROMOTING CHRISTIAN KNOWLEDGE;

NURTHUMBERLAND AVENUE, CHARING CROSS, W:C.;

43, QUEEN VICTORIA STREET, E.C.

BRIGHTON : I35, NORTH STREET.

NEW YORK: E. \& J. B. YOUNG \& CO.

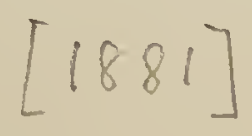



THE REVEREND JOHN ELLERTON, M.A., RECTOR OF BARNES,

This little Jook

IS AFFECTIONATELY DEDICATED. 



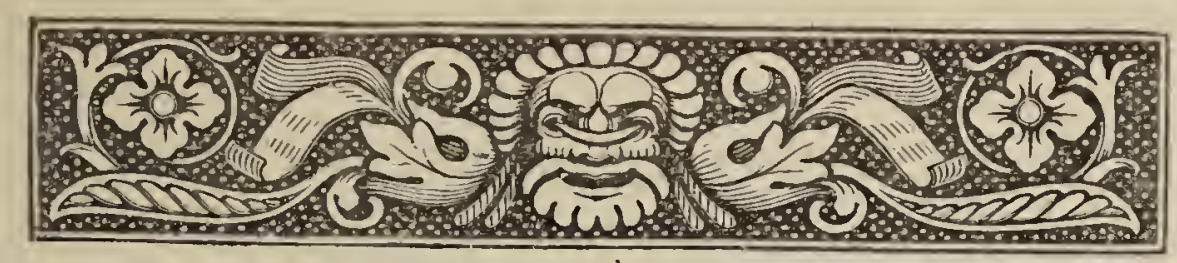

P R E F A C E.

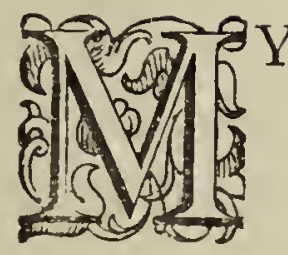

object in writing this book has been to point out the vast amount of pleasure and information which boys may obtain by forming a museum. Having myself formerly experienced the delight which such a collection is capable of affording, I am anxious to tell the boys of to-day how it was done, to encourage them to make a similar attempt. Many a schoolboy does not know what to do either with his spare time or pocketmoney, so both are wasted, and he becomes a man and takes his place among the toilers of the world with no hobby to turn to for relaxation in his leisure, with nothing to link him to the days of his youth, and to keep him fresh and young in heart as he combats with the anxieties of life. 
It has frequently surprised me to observe the amount of indifference to the things of nature which exists among the young men of the present day. The cause of this may be traced to the absence, in the days of their boyhood, of such pursuits as this little book records. Brought up with their eyes unopened to the wonders of nature, they pass through life in the same state of blindness; leisure often hangs heavy on their hands, the country-save for purposes of sport-is voted dull, travel is deprived of some of its greatest charms, and wisdom at many entrances quite shut out. How completely all this is reversed in the case of those who have early imbibed an enthusiasm for studying and collecting in any department of natural or historical science!

The following "Story of our Museum" is written, therefore, to show what can be done in the matter of collecting, when it is set about in earnest. The museum the history of which is herein recorded was commenced in the country and continued in London. It was formed by two brothers: the elder sleeps in a far-off land, under a monument on which public gratitude records how he served his country as "a good Citizen, a learned and incorrupt Judge ;" the younger tells this tale.

In conclusion, I beg to express the obligation 
I am under to several friends who have kindly assisted $m e$ in bringing the work up to the scientific standard of the day; to William Jeffery, Esq., late President of the Chichester and West Sussex Natural History and Microscopical Society, for revising the cnapters on Shells; to the Rev. James Fraser, M.A., for correcting some archaisms which had crept into the "Botanical Department;" and especially to Joseph Anderson, Esq., Jun., of Chichester, not only for bringing the chapters on Insects up to date, but alsc for writing an Appendix, full of valuable information, on butterfly hunting.

\section{H. HOUSMAN.}

Chichester,

October, r $88 \mathrm{I}$. 



\title{
CONTENTS.
}

\author{
$\rightarrow$ \\ CHAPTER I. \\ W OO DCHESTER.
}

Woodchester-Its situation-The vale of Rodborough-Site of the Roman villa-Was St. Paul at Woodchester?-The village-Character of its inhabitants . . Pages 17-23

\section{CHAPTER II. \\ OUR MUSEUM.}

Early passion for collecting-A museum begun-Its effects upon the character-Our books. Value of independent observation -Description of the museum--How fitted up and enriched

$24-29$

\section{CHAPTER III.}

\section{B I R D-S T U F F I N G.}

Results from shooting a Golden-crested Wren-Joe Wise, the village naturalist-We resolve to acquire the art of birdstuffing-A first attempt-Miserable failure-Sacrifice of the Golden-crested Wren-Light breaks in-Special difficulties - How to be overcome. 


\section{CHAPTER IV.}

\section{BIRD-STUFFING-continued.}

Attitude of stuffed birds-Grouping according to species-How we shot a Kestrel-Blackcock and Greyhen-GoatsuckerHow stuffed birds should be exhibited-List of our Stuffed Birds

\section{CHAPTER V. \\ BIRDS' EGGS.}

Charms of birds'-nesting-Not necessarily cruel-How to blow eggs-How to display them-Nests-Some of the most interesting .

\section{CHAPTER VI.}

\section{SIIRAWLEY.}

Shrawley Wood-A paradise for boys-Clearing out the welltrap-Horrible suffering caused by steel traps-Description of a Blackbird found in one-Importance of boys learning how to handle a gun-Fishing at Shrawley - The GroveLading the brook-The butterflies of Shrawley Wood 56-63

\section{CHAPTER VII.}

\section{"BIRDS OF A FEATHER FLOCK TOGETHER."}

A new acquaintance-His manifold acquirements-Story of the Hay hen-Learning to swim-Duties not neglected for pleasure-A happy boyhood . . . . . 64-68

\section{CHAPTER VIII.}

FISHING AND FISH-STUFFING.

The fishing at Woodchester-Reason of its excellence-Taught experience by a Jack-An invalid sleepy Jack-Strange conduct of a Carp-Hooking a large Perch-Charms of "The Boys' Own Book"-How we stuffed fish-The four orders of fishes: Placoids ; Ganoids ; Ctenoids ; CycloidsTheir appearance in geological time-List of Fish caught at Woodchester 


\section{CONTENTS.}

\section{CHAPTER IY}

\section{BUTTERFLIES AND MOTHS.}

Fate of most collections-Origin of our own-Fine huntingground for butterflies at Woodchester-Shelsley Hill-Scarce Copper-Moths-Death's-head Moths a nuisance-Setting butterflies and moths-The old method-A new one sug. gested-Its advantages-List of Butterflies and Moths in our museum

\section{CHAPTER $X$.}

SEA-SHELLS.

Curiosities in our museum-A valuable present-What we learned by arranging it-The six classes of MolluscaCephalopoda-Story of an Octopus-Gasteropoda-Abundance of genera-Pteropoda-Dearth of examples-Brachiopoda-Recent specimens why so scarce-Conchifera-The Pholas-Tunicata-Value of the study of Shells . 93-I07

\section{CHAPTER XT.}

FRESH-IVA'IER SHELLS.

Peculiar interest of land-shells-Twofold divisions of land and fresh-water snails-Cycladidæ-Peculiar feat of the Capped Cyclas-Unionidæ-Bede on British pearls-DreissenidæBritain invaded by a mollusc-Gasteropoda-Queer place to discover a Nerite in-Marsh-shells-Valve-shells-Planorbis -Bubble-shells-Fresh-water Limpets-How our British shells were displayed-What the collecting of them taught us-List of Fresh-water Shells in our museum . I08-II7

\section{CHAPTER XII.}

\section{LAND-SHELLS.}

Slugs not in favour-Testacella-How its character was vindicated-Danger of being found in bad company-Eleven genera of Snails-Amber-snails-Natural barometers-Glassy Snails-Their heartless behaviour-Snailets-An unenviable 
faculty-Snails-Mean conduct of an Apple-snail-The unloved one-Are Wood-snails and Garden-snails identical? -Why Southdown mutton is so sweet-How to find Pygmy Snails - Uses of collecting Snails-A pin's head in a passion ! -Bulimus - Frequent at Selborne - Marvellous power possessed by the Dull Twist-shell-Chrysalis Snails-Whorlsnails-Moss-shell-Close-snails-Varnished Shell-Agateshells-No accounting for tastes-Cyclostoma-Its beautyMethod of walking-Acme-Discovery of a new Snail-List of Land Molluscs in our museum . . Pages II8-I34

\section{CHAPTER XIII.}

THE BOTANICAL DEPARTMENT.

Why botany is repulsive-Best to begin with the Linnæan system-How to set about the study of flowers-Our plan of collecting-Specimens of each of the twenty-four classesThe Natural system-Exogens and Endogens-Some Linnæan classes identical with Natural genera-Course of study recommended-Geographical distribution of plants-Region of the Labiates-Suggestion for the title of an unnamed provinceHow to dry and preserve plants-List of some of our dried Flowers

\section{CHAPTER XIV.}

FOSSILS.

Abundance of fossils at Woodchester-Fossil-fever-Early inquiries-Publication of the "Gallery of Nature"-Wonderful revelations-Beginning to collect fossils-OldhamiaEozoön-Fossils of St. David's-Trilobites-Eye of Asaphus - Carboniferous flora - Liassic monsters - AmmonitesClimate of England in the Eocene period-Pairozoic fossils -Mesozoic-Tertiary-Prehistoric remains-Plan of collecting changed-Lingula - Rhynconella-Terebratula-Reading the past by the light of the present-List of our Recent and Fossil Brachiopoda . . . . . . I54-I 72 


\section{CHAPTER XV.}

MINERALS.

Of inferior interest to fossils - Rock specimens - Granites Basalt-Metamorphic rocks-Sandstones-Limestones--Coal -Metals-Copper-Tin-Bismuth-Precious metals-Lead - Sulphur - Rock-crystal - Agates - Precious stones-Hydrous silicates-Educational value of minerals-Mysteries of crystallization . . . . . . Pages 173-I84

\section{CHAPTER XVI.}

AUTOGRAPHS.

Autographs in British Museum-Royal autographs-Dr. ParrJohn Wilkes-Sir Joseph Jekyll-Scale of speakers in Parliament, 1826-Lord Erskine-James Stanhope-Amusing letter from Campbell-Mendelssohn-Nelson I85-197

\section{CHAPTER XVII.}

\section{POSTAGE STAMPS.}

Educational importance of a collection of postage stampsTheir introduction-Best way of arranging them . 198-200

\section{CHAPTER XVIII.}

\section{ROMAN AN'TIQUITIES.}

Woodchester classic ground--Site of the Roman villa-Early excavations-Lysons' explorations-Description of the villa -Opening of the remains-Description of the pavements - Roman antiquities in our museum-Influence of their study cn our education

- $20 \mathrm{I}-2 \mathrm{I} 2$

\section{CHAPTER XIX.}

OUR COINS : BRITISH AND ROMAN.

Discovery of a Roman coin-Method of collecting coins-Two ways of looking at coins-The artistic-Fluctuations in the art of coinage-The historical-British coins-Disputed passage in Cæsar-Roman-British coins-Series of the Emperors who had visited Britain-Of the usurpers--Story of Carausius -The Constantine family-The later usurpers . 213-230 
CHAPTER XX.

OUR COINS : SAXON AND ENGLISH.

Minimi-Sceattas-Stycas-Saxon coins-English coins-What does "s" in Paxs mean?-The Norman series-Discovery of Henry I. penny-Uninteresting character of groats-The Tudor series-Stuart and Hanover coins-How we collected coins-Their educational value-The lessons our museum taught us . . . . . . . Pages 23I-242

\section{CHAPTER XXI.}

CONCLUSION.

Review of the subject-Failure of our attempts to stuff quadrupeds-Our Fox-Lessons to be learned from collectingHints to boy-collectors-Exchanges-Hunting in old curiosity shops - Caution not to collect too widely - Is a little knowledge a dangerous thing?-Importance of studying a new acquisition at once-Value of a microscope-Generosity in collecting-Importance of accurate observation-Reverence to be cultivated-Duty before pleasure-Effects of studying nature upon the character . . . . . 243-254

Appendix A.-On the Arrangement of Natural History Collections . • • • • • • . 255-264

Appendix B.-How to collect Butterflies and Moths, with Notes on Preserving Larvæ . • • . 265-272

$\operatorname{INDEX} \cdot \quad \cdot \quad \cdot \quad \cdot \quad \cdot \quad \cdot \quad \cdot \quad \cdot 273$

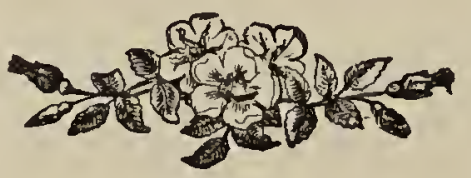




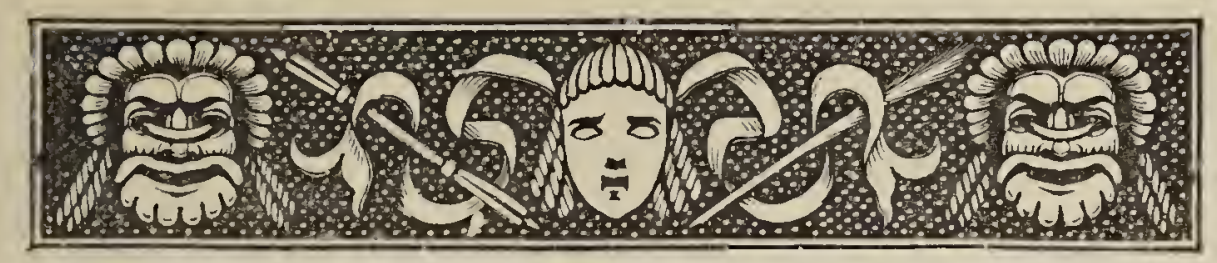

\section{THE STORY OF \\ OUR MUSEUM. \\ C H A P T ER I. \\ WOODCHESTER.}

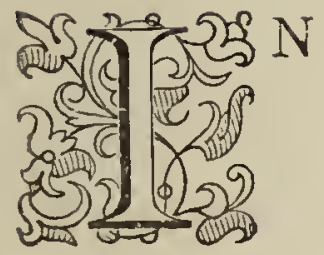

the spring of 1840 we returned, after an absence of some years, to Woodchester. This, like many another country village, is better known in these days than it was forty years ago. Now it has a railway station of its own, whereas at that time the Great Western had not got farther than Faringdon, in Berkshire, and when we travelled from London, the remainder of the journey from that town had to be posted. Now, too, it can boast of a post-office; then the letters used to be brought from Stroud, some two miles and a half off, by an old woman, who, with the exception of a few carriers' waggons, formed our 
only medium of communication with the outer world. Yet even then Woodchester was not nearly so obscure a village as many a larger one, for it was celebrated both for its cloth manufactories, to which George III. himself had once paid a visit, and for the remains of its Roman villa - the finest of its kind in the kingdom.*

The conformation of this part of the Cotswolds, with its regular succession of hills and valleys, reminds one of a series of vast Atlantic billows suddenly arrested and transformed into fertile dry land. One of these depressions, running nearly north and south, forms the beautiful vale of Rodborough, through which passes the main road from Stroud to Bath; and cn its western slopes, about half way between. the former town and Nailsworth, lies the village, or rather since it is in two divisions, the villages, of Woodchester. Stroud, the capital of the cloth manufacture of Gloucestershire, stands on a hill which forms the northern termination of this valley, and although a large and busy town, a short time suffices for a pedestrian to exchange the bustle of its streets for the quiet of the country. The Bath road, leading as I have said through the vale of Rodborough, is

* Whether the lately discovered villa at Brading, now in course ol excavation, will surpass it in magnificence, remains to be seen. 
of singular beauty. At first it winds under Rodborough Hill, crowned with its useless though picturesque fort-built, I believe, at the time when all England was daily expecting a Napoleonic invasion-while to the right runs a stream, too small to be named, but large enough to be useful, as the various manufactories which have sprung up on its banks testify. It is bluebluer at times than the Mediterranean itself, but not from the same cause, since it is less indebted to the reflection of an azure sky than to the indigo and other refuse dyes of the cloth mills, which have so poisoned its waters that the trout, with which tradition says it formerly abounded, have long since disappeared, leaving their place to be filled by roach and eels, whose less delicate constitutions do not mind such trifles.

About two miles from Stroud a side road crossing this stream by a small bridge forms the directest approach to Woodchester; and after passing a little brook which comes rushing down from the hills on the right, the visitor soon finds himself on a gentle eminence, close by the old parish church, and surrounded on all sides by enchanting views. This is classic ground, for he is now standing on the site of the famous Roman villa, where it is not impossible the Proprætor may have dwelt, and from whence he governed the whole island. Some, indeed have 
gone so far as to hint that the Emperor Hadrian himself made it his palace, but one always observes that no Roman site is ever allowed to lose prestige for lack of conjectures, on the part of local enthusiasts, as to the celebrities who may have paid it a visit. In fact, our dear old Rector had quite convinced himself, if nobody else, that St. Paul had preached, if not exactly in, yet at all events on the site of, his own church. "For," he would argue, "does not Clement of Rome say that the great Apostle went to 'the utmost limit of the West'? and was not Britain that utmost limit? Therefore St. Paul came to Britain. But if he came to Britain, he would be sure to visit the Roman governor; and since he lived at Woodchester, St. Paul would come to him here also; and if he came, it would be for the purpose of preaching the gospel. Therefore at Woodchester, in the Proprætor's palace, on the site of which now stands the church, has St. Paul most undoubtedly preached!" It was an innocent dream of the good old man's, and harmed no one, and I never heard that anybody was cruel enough to try to dispel it.

Leaving the old parish church, the road, bearing to the left and skirting the rectory gardens - noted for their fine ornamental trees-takes a turn to the right, and if followed straight 
on up the hill would lead to an extensive plain, called Shelsley Hill, noted for its large quarries of building stone abounding in Inferior Oolite fossils, and for the magnificent view from the farther side, overlooking the valley of the Severn, and extending to the Malverns, and even to the Welsh mountains beyond. The finest point to enjoy this is an artificial mound locally called "The Tump," which, from its position and shape, I have no doubt is the burial-place of some Saxon chief. If, however, instead of following this road up the hill, we take the first turning to the left, after passing the cottages and schools which form a considerable part of this northern division of the village, of "Near Woodchester," as it is called, we soon find ourselves in the fields again. Just on entering them there is a spring of clearest water, which gives the name of Frogmoor to the meadow, while on the left-hand side of the path stands the new parish church, conveniently situated midway between the divided districts of the parish. A little further on the road dips into a little valley-it would be a combe in Sussexrunning up into a wooded hollow on the right. At the bottom we cross a bright little trout stream, coming down from the head of the valley, and forming a fine mill-pond on the left - of which more by-and-by, when we come to talk about 
Roach and Jack. Immediately after crossing this stream, the path takes a steep ascent, at the top of which stands our old home, Woodchester House, nestling in its shrubberies and gardens. Skirting the front lawn, we soon find ourselves in "Far Woodchester," the southern and more populous of the two divisions of the village. Here is the post-office, the dissenting place of worship, and the big shop of the village, with its groceries, medicines and tobacco, butter, cheese, and other necessaries for the inner man on the one side; and blankets, dresses, gorgeous neckties, and such like comforts for the outer man on the other. Still keeping to the right, after passing this universal store, as it would be called in America, the houses become fewer and farther apart, until they cease altogether, and we come to a seciuded demesne, called Atcombe, lying, as its name implies, in a combe, down which runs a rivulet which forms the Atcombe ponds, our favourite perch preserves, and whose banks, fragrant with water-mint, afforded a congenial home to the moorhen and the kingfisher. The path, which passes between the head of the upper pool and the tail of the lower, joins a lane which, after wandering for a mile or two amid charming scenery of the truest rural type, leads to Woodchester Park, in our day belonging to Earl Ducie, but which has long since 
changed hands, and become a stronghold of the Romanists.

Just before reaching the park gates, there used to stand-its very ruins are now indistinguishable - a tumble-down cottage, with a garden, in which was a little pond growing the finest watercresses in the parish. Here lived a venerable old couple named Dix. William was ninety, and Penelope his wife-we were very fond of grand names in Woodchester-was five years older. Nothing pleased these dear old people so much as to pay them a visit, to taste their watercresses; and when we went and took a cup of tea with them on a summer evening, their joy was touching to see. Then old William would take down his shears and hobble to the pond, and cut such a dish of cresses as I have never seen or tasted since; while poor old Penelope, deaf as a post, would lay her quaint old china on the clean coarse cloth, and think no honour she could bestow adequate to the occasion.

Such is, or perhaps I must say was, Woodchester; of more varied beauty even than Selborne, lovely as that is, and far exceeding it in the interest of its antiquities; while for genuine warm-heartedness its inhabitants could not be surpassed by any rustic population-its very labourers were gentlemen. 


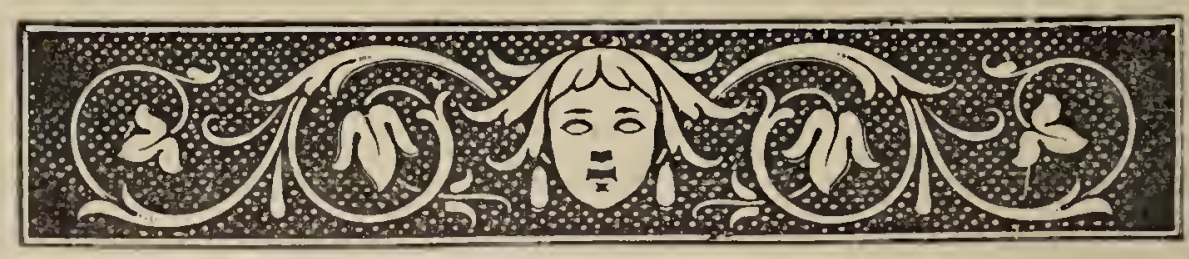

\section{$\mathrm{C}_{1}$ HAPTER II.}

OUR MUSEUM.

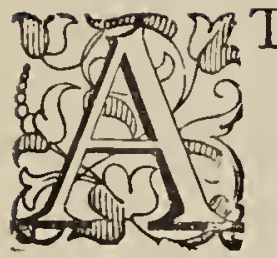

T the time of our return to Woodchester, I was eight, and my brother Frank three years older. What it was that awoke within us a passion for collecting and studying the natural history and antiquities of the neighbourhood I cannot say-it must have been born in us, I suppose. Still, it would have been almost impossible for any lads of ordinary intelligence to have suddenly found themselves in a lovely country, abounding with birds, butterflies, fossils, flowers, and Roman remains, without taking some interest in them. This, however, I can say, that the ruling passion grew within us quite spontaneously, without any forcing or encouragement from without, one thing leading to another, until we found ourselves in possession of an assemblage of objects, which we called our 
"specimens," and everybody else our " messes." These, however, soon became so intolerable, and interfered so decidedly with the cleanliness and tidiness of the house, that, as a compromise, a room was assigned to us, with the understanding that we should keep ourselves to it, but that if fossils or dead birds, etc., were found in the drawing-room or elsewhere, they would be instantly confiscated.

Willingly agreeing to such terms, we took possession of our room at the top of the house with infinite satisfaction, and began to fit it up with home-made shelves and transformed packing-cases, and stuck over the door a card, on which was inscribed in capitals of the boldest description-MUSEUM. All our spare time -that is, when we were not out of doors occupied in hunting for new specimens, or in fishing, in which we were great adepts-it was our delight to spend here, stuffing birds, arranging, dusting, label-writing, catalogue-making, or reading. On looking back in after years to this period of our boyhood, I am sure neither of us has ever regretted the time thus spent. We may not have got through our Latin and Greek as fast as many other boys of our age-that we made up for afterwards; but we were learning to observe, to use our eyes and ears, and to acquire that indefinable love for all living crea- 
tures and that sympathy with the past which, once gained, never leaves a man. Between us we have since visited every quarter of the globe, and, speaking for myself, I can truly say that one of the greatest charms of foreign travel has been that of carrying with one, into new fields of observation, the interest and the understanding of natural objects gained in the years of boyhood.

The stock of books on our favourite subjects was, as may well be imagined, but scanty. It contained six volumes of the Naturalist's Library, viz., "British Birds," "Butterflies," and "Moths ;" White's "Selborne ;" Mudie's "British Naturalist;" and Walton's "Angler ;" to which in course of time we added Waterton's "Wanderings," and his delightful "Essays." We had also Mrs. Trimmer's two amusing little volumes on natural history. In the rectory library was an old edition of Buffon, which we sometimes borrowed when our own resources failed. On mineralogy and geology we had some cheap handbooks of the day, not very advanced indeed, and containing information which would be laughed at nowadays; but we made the best use of what we had, and in course of time corrected and enlarged our knowledge as better works came within our reach. The appearance of Milner's "Gallery of Nature," which came out in numbers in 1846 , was an 
event in our lives, and from the latter chapters on geology we gathered our first definite idea of the wonderful interest and geological value of fossils. For flowers our only books were that charming work by Caroline A. Halsted, entitled "The Little Botanist," which to this day is quite unsurpassed as an introduction to the Linnæan system, and Hooker's "British Flora." As to shells, and especially the relation of the fossil to the recent species, we were entirely in the dark until the publication of Dr. S. P. Woodward's invaluable "Manual of the Mollusca." Upon the subject of coins and antiquities we had no books whatever, and had to be content with what light we could extract from our school histories. Such works as Wright's "The Celt, the Roman, and the Saxon," with its full description of our own Woodchester; or Humphrey's "Coin Collector's Manual," had they been published in our day, would have turned our heads with joy, and given us no rest until we had devoured and digested every word of them. Boys of the present day have knowledge made easy for them, and are wellnigh overwhelmed with facilities for acquiring information such as were never dreamed of in our youth. At the same time, if knowledge is got too easily, it is neither so much valued nor so lasting as when it is self-acquired by excrtion 
and independent observation. Besides, it gets lads into the habit of flying to books in the first instance for information, instead of hunting it out for themselves in the woods and fields. This weakens the power of original observation, and engenders a feeble leaning on second or third hand authority instead of carefully trusting to themselves to discover it. But provided the beautifully illustrated natural history books and periodicals of the day are judiciously used, and are not made the means of substituting a superficial smattering for a thorough grounding in the principles of science, the boy of the present day may make more progress in a month than we did in a year.

On entering our museum, the chief object that met the eye was the large glazed case, four feet wide and five high, fitted with shelves, and full of stuffed birds. This was fixed on the wall about five feet from the floor, and under it were three shelves covered with paper trays, containing fossils and general curiosities. Beneath were the butterfly cases. On the other walls were fixed cases of birds. There was a bookshelf, with our books on natural history, and under it a shelf for the dried flowers and autographs. The shells were in boxes on the floor. A disused workbox filled up with pierced trays held the coins; and the birds' eggs were kept in some 
large shallow boxes, two of each sort in a paper tray. The stuffed fish were displayed on thick cards hung upon the wall, and the Roman remains had a shelf to themselves.

All the fittings of the room were made by ourselves, with the exception of the large birdcase, which was the result of a long and careful saving of pocket money, birthday presents, and Christmas-boxes. It was always a proud day for us when any visitor came and took the trouble to look at our collection, whilst our satisfaction in showing and explaining everything was unbounded; and we always learned something by the remarks made during such visits, and not unfrequently received the present of a coin, an autograph, or some other valuable, and thus our museum grew.

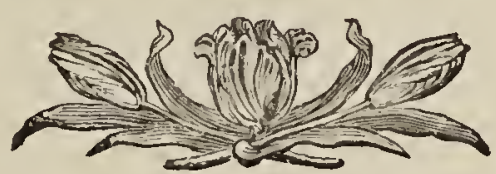




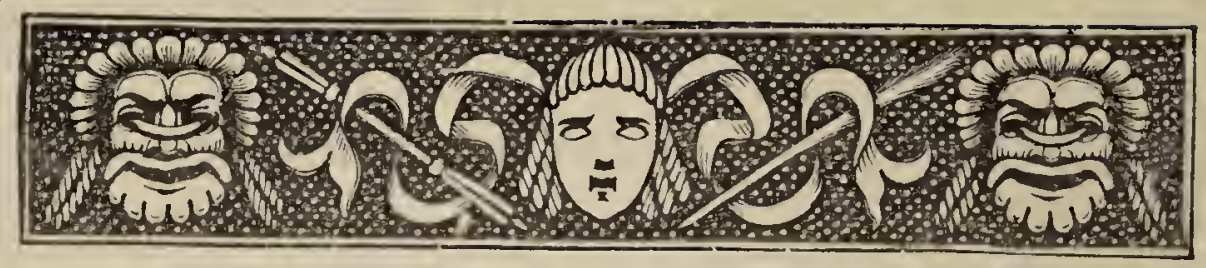

CHAPTER III.

BIRD-STUFFING.

4 S I have said, our museum took its is rise from very small beginnings; in fact, I think it may be traced to a Golden-crested Wren-the smallest of British birds - which our eldest brother, when at home during a winter vacation, shot in one of our fir trees. The little victim was so pretty, that it struck us it ought to be stuffed; but who could perform the operation? Now it so happened that among the lads of the village was one Joe Wise, a "pointer" at the neighbouring pin manufactory, a curly-haired, merry young fellow of eighteen, with laughing blue eyes full of mischief and merriment, who was the naturalist of the neighbourhood, loving the woods and all that was in them, and spending his whole time when not at work in shooting birds and stuffing them, To this congenial 
spirit therefore we betook ourselves with our Golden-crested Wren, and perhaps it was the sight of Joe's room, hung round with cases of beautifully mounted specimens, that inflamed the desire already kindled in us to make a collection of stuffed birds. From that day we began in earnest. Seeing that birds could be stuffed, why should not we try to stuff them ourselves? for to give eighteen pence, which the stuffing of the Wren cost, for every bird we intended to possess, was obviously out of the question. Had the "Hunting of the Snark" been out in those days, we should certainly have applied to bird-stuffing the words with which the butcher braces himself to the enormous task of adding two to one-

" 'The thing can be done,' said the butcher, 'I think. The thing must be done, I am sure.

The thing shall be done! Bring me paper and ink, The best there is time to procure; '"

and, like the undaunted butcher, we set about our task in the most difficult way possible. Instead, however, of paper and ink, we got turpentine and some coarse copper wire which a bellhanger had left in the house, and proceeded to operate upon an unfortunate Wood-pigeon we had contrived to shoot. Every stage of the process bristled with peculiar and unheard-of difficulties. First, we essayed to skin the crea- 
ture by making an incision down the middle from stem to stern, beginning at the beak, then down the neck, along the breast and stomach, till we could get no further. So far so good; but the feathers would come off at every turn, and those that were left soon got hopelessly sodden and caked together with the blood, fat, and contents of the stomach into which the knife had dug. Still, nothing daunted, we went on, pulling the skin away from the flesh until we came to the legs. How to get them out was the question, but by our united efforts it was accomplished, first cutting them through at the hip, and then pulling the skin of the thigh from the flesh right down to the knee-joint, which we severed, taking away the whole of the thigh, bone and all. Both legs being thus served, we came to the tail, which puzzled us even worse than the legs. At last, getting desperate, we cut right through the abdomen, as low down as possible, and a precious mess was the result. We then tied a string round the half-stripped carcass, and securing the other end of it to the door handle, we tugged the skin off the back, and so came to the wings. These we treated as we had done the legs, only the difficulties were greater, owing to the number of joints and turns which had to be surmounted before we arrived at the meatless region, and in accomplishing this some of 
the long feathers came out, the others resolutely fixing themselves the wrong way. Skinning the neck was easy, seeing that the whole length of the throat had been cut open; but the head was worse than all the rest put together. In skinning the eyes they burst, and deluged all the head-feathers with a liquor composed apparently of dirty gum and frog-spawn. At last, a vigorous cut right through the base of the beak, causing the upper and lower mandibles to fall asunder, completed the first part of the operation.

By this time we felt the profoundest respect for the character and attainments of Joe Wise. Melancholy and abject in the extreme was the spectacle which that skin presented! Without, however, stopping to cry over it, we entered upon the second stage of the process. How was the skin to be preserved? Pepper and salt had been the original idea, but on reflecting that insects abhorred turpentine, we inferred that this would prove still more effectual. Whereupon we began to lay this on and rub it in as thick as we could, until not our room only but the whole house reeked with the smell, and in fact hints were thrown out that day at dinner, that if we were to transfer the scene of our industry to the toolhouse at the farther end of the garden- - We changed the subject.

The anointing accomplished, next came the 
crowning difficulty-how to get some appearance of life, however remote, into this miserable, sodden, half-naked skin. We began by cutting six lengths of copper wire, and thrust two up the legs, two through the head and tail respectively, and one through each wing, and with much ingenuity and labour contrived, with the aid of a pair of pincers, to twist the interior ends into a knot in the middle, and the creature once again stood on its legs. Then we stuffed tow into the skin, and when it would hold no more began to sew it up, beginning under the chin and continuing down to the tail. We then walked over to Stroud, and bought a pair of glass eyes, but found it no easy matter to induce them to stop in their places when we had got them. One would seem tolerably firm in its socket, but the instant we began to insert the other it seized the opportunity of tumbling out again; but by dint of perseverance and gum, we at last persuaded both to stick in. The various wires were then bent into position, and finally, fastening the ends of the wire which protruded through the soles of the feet on to a piece of board, enjoyed our triumph. But we could not conceal from ourselves it was a pitiable object to behold. What few feathers had survived the operation, were either blood-stained, greasestained, or turpentine-stained; the head would 
not stay at the end of its wire, but dropped down to the breast; no art could hide the gash from chin to tail; the skin of the thighs clung tightly to the wires, and no persuasion of ours had any effect in inducing the ruffled plumage to lie down, the quills of the wings setting the example by sticking straight out; the expres-

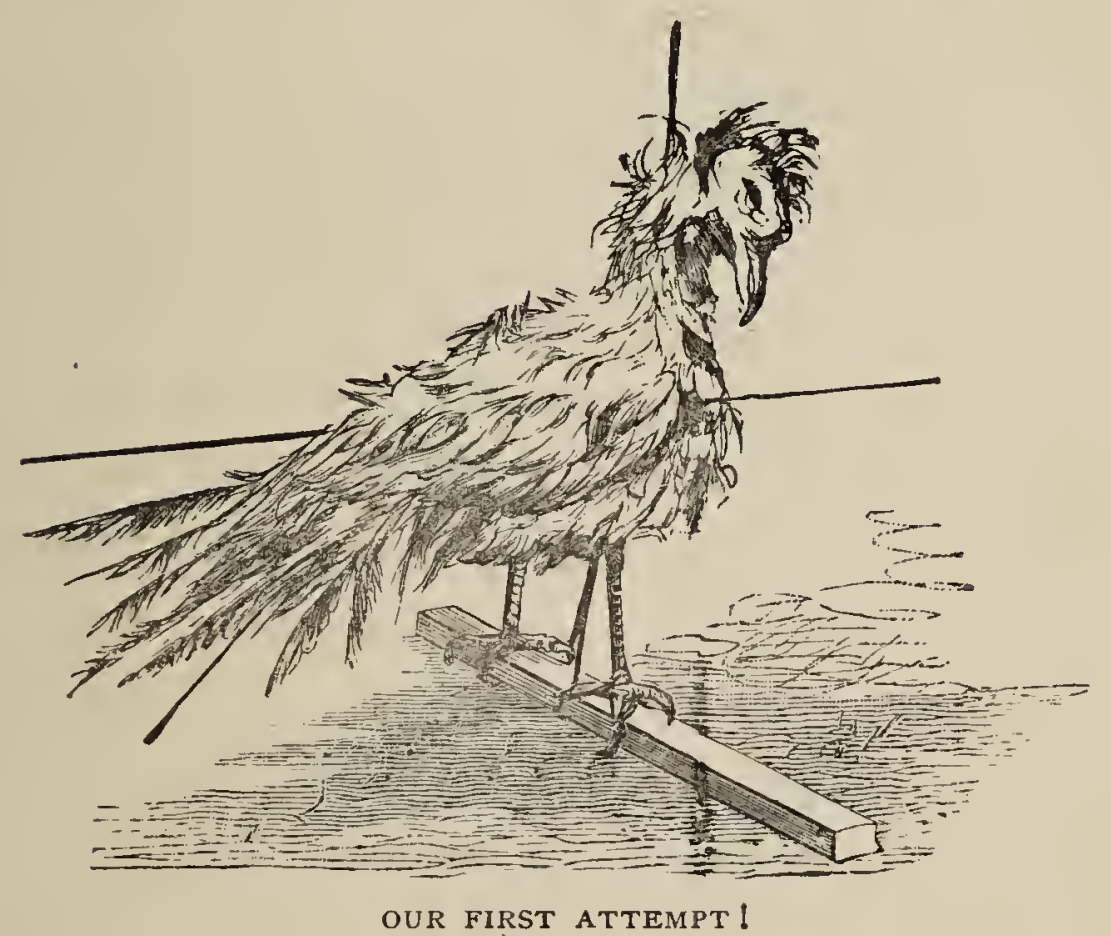

sion of the eyes was ghastly. We considered Joe Wise altogether a superior being.

Such was our first essay in taxidermy, but at all events, it taught us what a difficult art it is, and how much we had to learn before we could hope to succeed in it. We should have liked to have had lessons from Joe Wise, but he did not choose to disclose the secrets of an art which brought him in considerable profits, so there was 
nothing for it but to go on trying until we did succeed. Suddenly a brilliant thought struck my brother Frank. "Let us cut open the Golden-crested Wren, and see how it has been stuffed!" No sooner said than done. We carefully detached it from its spray, and then unstuffed it. It was about the best lesson we could have had, for are not all the fine arts learned by studying masterpieces? It showed us many of our mistakes. We observed in the first place that, in the skinning, the incision had not gone higher than the top of the breast, the neck not having been opened at all. Next, that the interior ends of the wires were not fastened by twisting together, but by being firmly imbedded in a neat, semicircular piece of cork. This had been done by the wire being pushed through the cork, the end turned into a hook and drawn back; the skull had been left in, with the exception of the hinder part where it had joined the neck, and the cavity where the brains had been, filled with a piece of cork, so that the wire passing through it held the head firmly in any required position. Then, again, the thigh-bones had been left in, and an artificial thigh made by winding a little cotton wool round the bone; and finally, that fine cotton wool, not coarse tow, was the material employed for stuffing; and that arsenic, not turpentine, was the preservative agent. Happening 
to be in Joe Wise's room soon after this, we observed that his newly stuffed specimens were all carefully bound round with thread, so that every feather was brought into its proper position, and kept there till dry.

Our next attempt, which was upon a Starling, was much less unfortunate; the sacrifice of the Golden-crested Wren had not been in vain, and by carrying into practice the lessons it taught us, our progress became rapid. Later on, we attempted Waterton's method, which dispenses with wires altogether, but could make nothing of it; the skin without such supports becoming a bag, which no art of ours could transform into a bird. One thing, however, we learned from his "Essays," namely, to use a solution of corrosive sublimate dissolved in spirits of wine instead of arsenic or arsenical soap, and the specimens so treated still retain their original beauty, whilst those for which arsenic was employed soon became meat for moths.

After all, perhaps the most difficult thing about bird-stuffing is the skinning; which requires a vast amount of practice to do properly. Almost every species presents special difficulties of its own. In some, like the Tree-creeper, not only do the feathers come off almost if you look at them, but the skin is so excessively delicate that it tears like wet tissue paper. It 
takes much practice to skin a Bullfinch without the white feathers over the tail coming off in your hand. The head of the Owl is so large that the neck must be slit up, which seriously endangers the success of the operation. The plumage of water-fowl and all sea-birds is apt to get oily, and the utmost care must be taken to prevent a single feather touching the flesh or the inside of the skin. This, indeed, is necessary for all birds, as the awful spectacle of the Woodpigeon taught us, and we soon learned the necessity of inserting plenty of cotton wool as fast as the skin is separated from the flesh. Then, again, it takes some time to skin the eyes, so as neither to allow the eyeball to break, and the crystalline humour to wet the plumage of the head, nor to cut the eye-hole so as to make it larger than nature intended.

These and a hundred other points can only be taught by experience, but the art is in itself so fascinating in its results, that it is worth any amount of toil and perseverance to acquire. It has besides another advantage, that of teaching a boy to use his fingers with skill, strength, and delicacy. If any boy should feel inclined to stuff birds, he should begin on the easiest, those of a good size, and which have strong skins and firmly attached plumage, like starlings or the thrush family; and if he is resolved not to be discouraged 
by any number of failures, and to take every opportunity of learning what museums or other collections afford, he may be assured of success, and that before long he will be surrounded by an assemblage of beauties, each with its own little history, which, it may be, will be the ornaments of his home and the companions of his leisure hours, when the days come in which the real business of life will no longer leave him leisure to roam the woodlands and observe his feathered favourites in their natural haunts.

Books. - I do not know any book on Birdstuffing; in fact, it is an art which can hardly be taught, save in its first principles, by a book. "Notes on Collecting and Preserving Natural History Objects," edited by J. E. Taylor, F.L.S., F.G.S. (Bogue), is full of general information, but it does not include taxidermy.

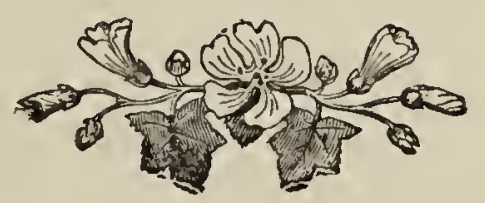




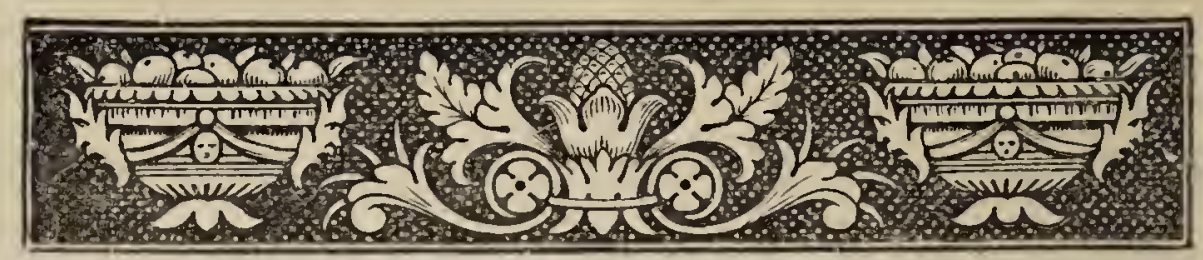

CHAPTER IV.

BIRD-STUFFING-continued.

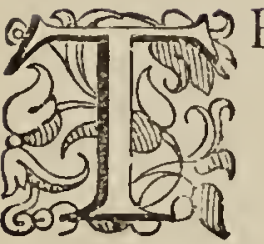

HE poetry of bird-stuffing consists in setting up the specimens in proper attitudes, such as represent faithfully their natural instincts and habits. Formerly, the operator-I will not call him artist - thought his task accomplished when his specimens, whether Hawks, Woodpeckers, or Swallows, stood on a spray of wood or a bit of board, with their heads turned regardant to the spectator. Such abominations the national and most of our local museums * have by the mile, though many exquisite examples of a higher art are gradually being introduced.

From the first we conceived a horror at giving our birds the conventional attitude, and would no more have thought of making climbers, like Woodpeckers, the Nuthatch, or the Tree-creeper

* See Appendix A. 
stand on a spray like a Sparrow, than we should of representing a Moorhen in the act of running up a tree, or a Dove eating a mouse. We acquired sufficient knowledge of carpentering to make our own cases, and Tom Collett, the village glazier, one of our firmest friends, put in the glass. As far as was practicable, we put birds of the same genus together. The Tomtits made a very pretty family group. In one corner was the nest of the Long-tailed Titmouse, which had been cut, branch and all, out of a hawthorn bush. One of the old birds was in the act of entering the nest, while the other had apparently just arrived with a grub in her mouth, thus suggesting that the nest contained the young. A pair of the Great Titmouse were conspicuous in front, and a pair of Coles on one side, while a couple of Blues were busy searching for insects on a mossy branch of apple tree on the other. The Bearded Titmouse was the only one of the family we never saw at Woodchester. We were rather proud, too, of the Finch case, containing the House Sparrow, Mountain Sparrow, Chaffinch (and nest), Mountain Finch, Goldfinch, Siskin, two of the Redpoles, and Mountain Linnet. The Wagtail group was another success, and likewise the Buntings. But the chef d'cuvre of all was unquestionably the pair of Kestrels which occupied the place of honour in the middle of our 
museum table. The male bird sat upright on a thick branch, sleek and satisfied; while just below, on the ground, the female-the larger of the two-was tearing up a mouse, whilst the ground was strewn with pellets cast up after former meals. I forget how we came by the male bird, but the capture of the female was a triumph. On the southern side of the Atcombe valley was a fir wood wherein, according to tradition, flocks of Crossbills had from time to time been seen in former days. Exploring this wood one day, we discovered at the farther end of it a cave, and in this cave evidences that it was the roosting-place of a Kestrel. Below the ledge on which the bird passed his nights, the ground was strewn with pellets such as all birds of prey throw up. They consisted of the fur and bones of mice, and shards of beetles, and other indigestible substances, while the loose feathers lying about revealed plainly enough what particular bird of prey it was which had chosen this cave for its home.

It was one thing to discover the Kestrel's lair, but quite another to catch the Kestrel himself. After much deliberation, we agreed to lay the gun on a couple of forked sticks fixed in the ground, and pointed so as to cover the spot where the bird roosted, and then, by means of a long string tied to the trigger, to fre it when 
he had gone to roost. No time was lost in putting this barbarous gunpowder plot into execution. A calm evening-it was winter-timewas chosen, the stakes were fixed, the gun laid upon them accurately pointed, the string tied to the trigger, and we, with the other end of it in our hand, concealed ourselves behind a bush. We had not lain there long before there was a sudden rush of wings, and the bird swift as lightning darted into the cavern. Now was the time; but, cautious as we were, the movement of the string was perceived, and the suspicious bird flew out again. Frank then, taking the gun into his hands, crouched behind a tree nearer the entrance to the cave, while I stopped where I was. We had a long time to wait, but at last the bird glided again into the cave. Frank rushed from behind the tree; the startled bird again flew out. Frank fired, and although the Kestrel was just disappearing in the twilight over the firs above the cave, we saw it was hit. Putting down the gun, Frank dashed after his game, and in a few minutes I heard the joyful cry, "I've got him," and he soon reappeared, struggling through the bushes with the bird in his hands. A single shot only had struck it, but that had broken its wing. For a lad of fourteen, it was a wonderful feat; but I had seen him, some time before this, take 
the great heavy double-barrelled gun out of the hands of John Wormington, the head keeper at Shrawley, and bring down a swallow which was circling far overhead, in a style that made the good man stare.

All our skill was exerted in the stuffing of a specimen obtained with such difficulty, and Joe Wise himself gave the finishing touches. It was a female, and, as I said, was placed in the act of tugging, with half-spread wings, at. a mouse, while her mate was sitting by.

Receiving one day a present of game from the moors, we were allowed to operate upon a splendid Blackcock and Greyhen. These, the cock standing up on the look out for danger, the hen sitting on the grass beside him, made a noble pair, and matched a brace of Partridges placed much in the same attitude. Once, while visiting my eldest brother in Kent, I found, not the nest indeed, for the bird makes none, but the two eggs of a Goatsucker, or Nightjar, laid on a smooth spot amongst the stones which they so much resemble, under a bush in an oak wood. Soon after I got the parent bird, which became one of the ornaments of our museum, as she crouched along, not across, a thick branch, with her vast mouth shut-not open for visitors to look down her throat, after the manner of the bird-stuffers. These two points I had particu- 
larly noticed, namely, that when at rest on a tree, this bird sits upon the branch lengthwise, and not crosswise, and that she does not sit, like an idiot, with her mouth open; yet in every museum I have seen, the reverses of these two acts are insisted on. As to the Swallow tribe, they had for convenience' sake to stand, which, though not the attitude most suggestive of their habits, is allowable, since they do perch occasionally, especially when making arrangements for their autumn migration. With the Swift it is otherwise; he never sits either on ground or tree, and we accordingly had to represent him in the act of flying, by passing a strong wire from the extremity of the wing into the side of the case.

This setting-up of birds naturally is, as I began by saying, the very poetry of the art. It must be learned direct from nature. The most skilful bird-stuffer, if he does not follow the birds into their haunts, and observe them there, will fail in the most important point of all. Hence it is that most London-stuffed birds, though often marvels of mechanical skill, are seldom pleasing to look upon. The artists have no time for the woods and mountains, and so can only place their specimens in conventional attitudes. Then there is another thing required for carrying out this principle 
thoroughly, and that is space. If every species is represented, as in theory it ought to be, by the male and female, nest and eggs, with appropriate surroundings, it would require a large apartment to exhibit even the British series, and many a gallery to illustrate the ornithology of all countries. Cases against the wall are the worst possible places to exhibit such a collection in ; the specimens ought to be in glass cases, round which the visitor can walk, and study them from every point of view. But as I am not writing to tell other museums what they might do, but only to record what we did in our own little museum, [ must stop, especially since I have said more on this subject in another place.*

The following is a list, so far as I can remember it, of the birds we had in our museum. The asterisk marks the species of which we had eggs.

\begin{tabular}{|c|c|c|}
\hline English Name. & Latin Name. & Locality. \\
\hline $\begin{array}{l}\text { Peregrine Falcon... } \\
\text { Hobby ................ } \\
\text { * Kestrel............... } \\
\text { * Sparrow-Hawk..... } \\
\text { Long-eared Owl ... } \\
\text { Short-eared Owl .... } \\
\text { * Barn or White Owl } \\
\text { * Red-backed Shrike } \\
\text { * Spotted Flycatcher } \\
\text { * Blackbird ............. } \\
\text { * Ring-Ousel........... } \\
\text { Missel-Thrush....... }\end{array}$ & 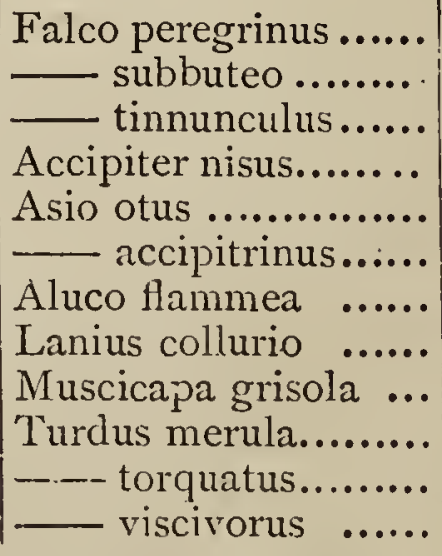 & $\begin{array}{c}\text { Caldy Island } \\
\text { Shrawley } \\
\text { Atcombe Wood } \\
\text { Woodchester } \\
\text { ", } \\
", \\
", \\
", \\
\text { Yorkslire } \\
\text { Woodchester }\end{array}$ \\
\hline
\end{tabular}

* See Appendix A. 


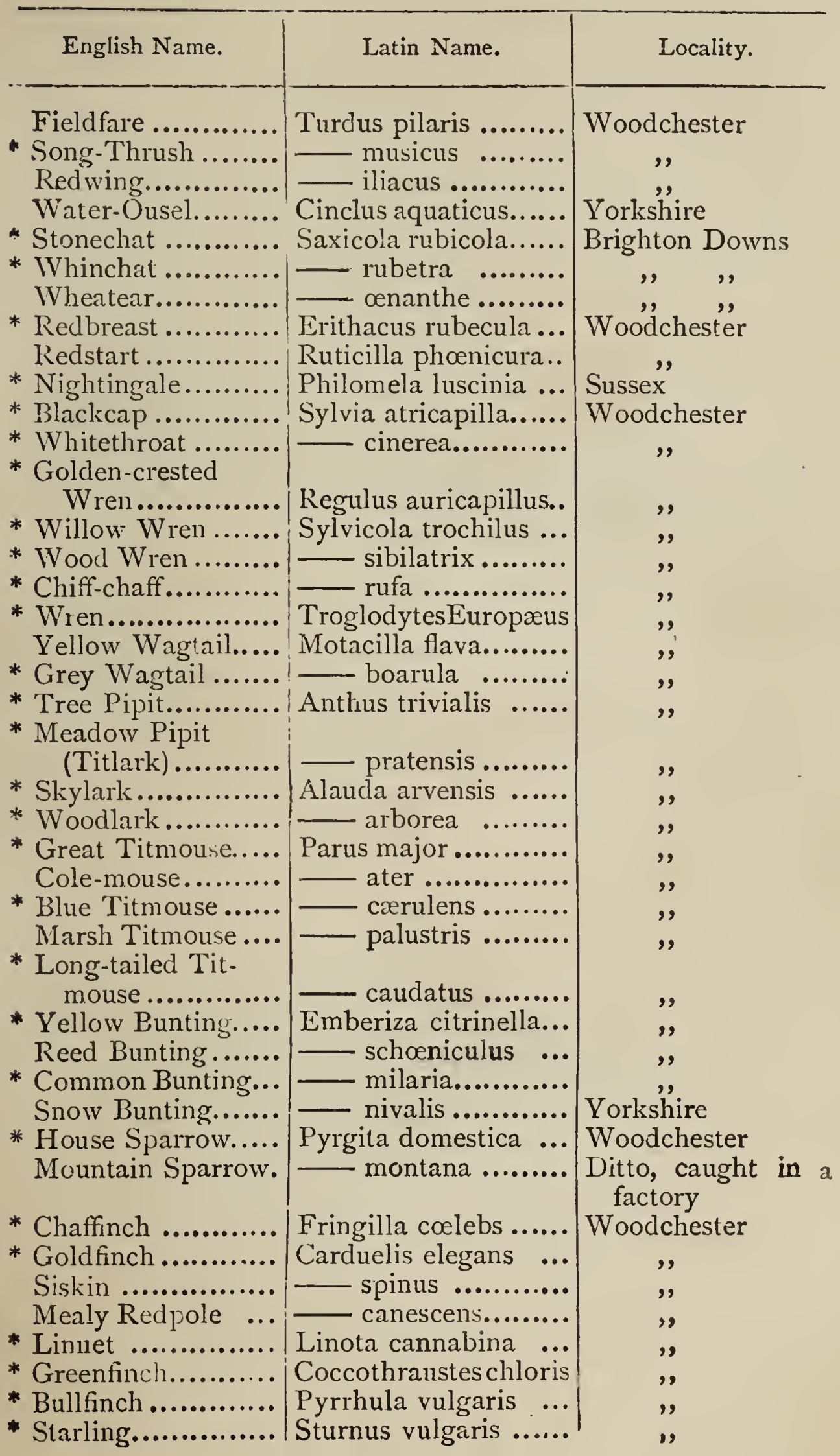




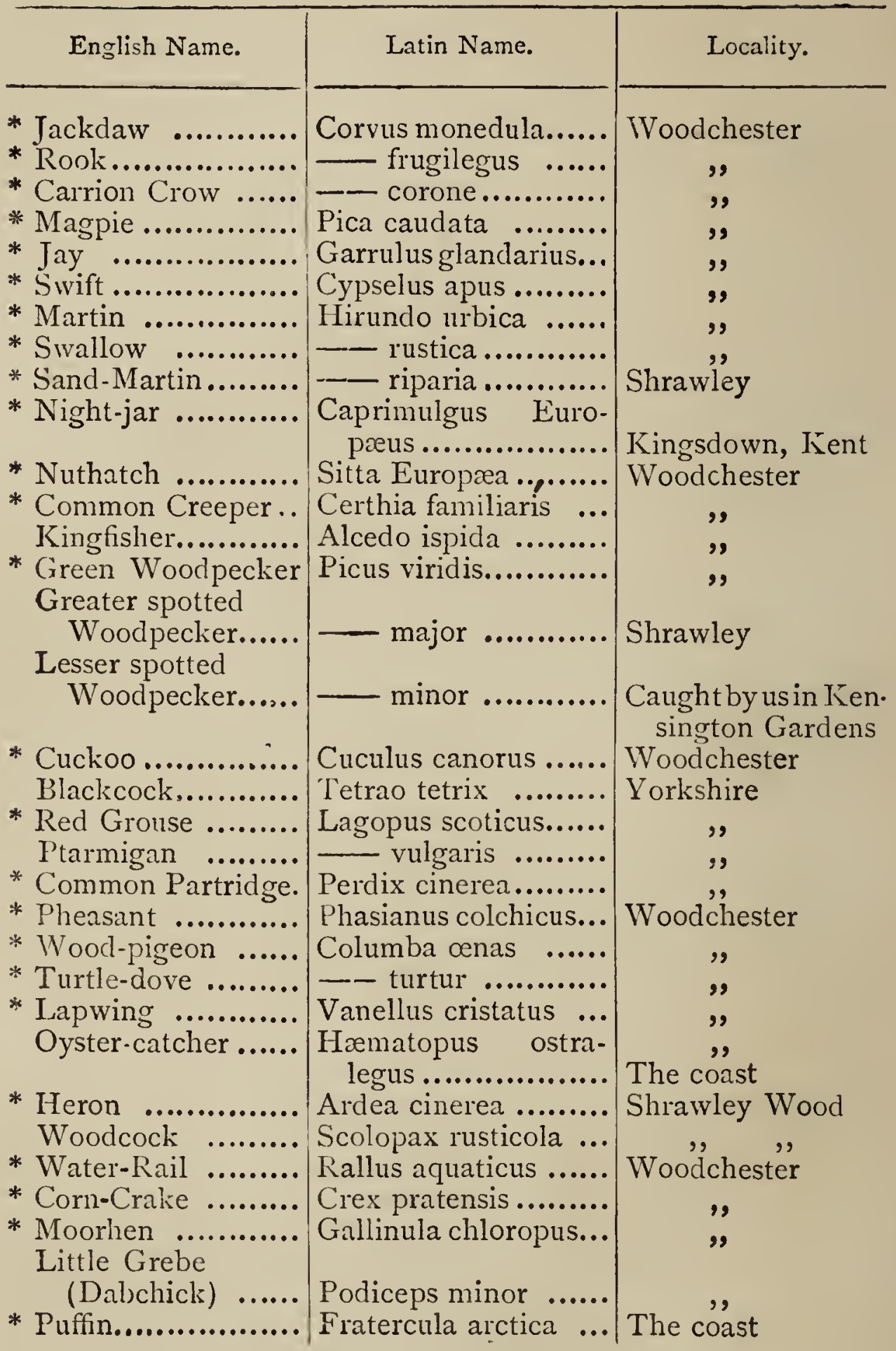

Considering we had no opportunity of getting sea-birds, and but very few of the marsh or water-fowl, this list is not so bad. Now and 
then we had a present from a distance, as the Grouse, Ptarmigan, and Ring-Ousel from the Yorkshire moors testify, as well as the Puffin, which came somewhere from the coast. The Selborne list contains one hundred and fiftyone species, whilst ours only shows eighty-eight ; but White's ground being so much nearer the sea, and the South Downs being in the direct line of migration, may well show a more extensive fauna. That district, moreover, has long been watched by experienced naturalists, whereas the above list is only the result of the leisure hours of a couple of schoolboys.

Books. - "British Birds in their Haunts," by the late Rev. C. A. Johns, B.A. (S.P.C.K.).

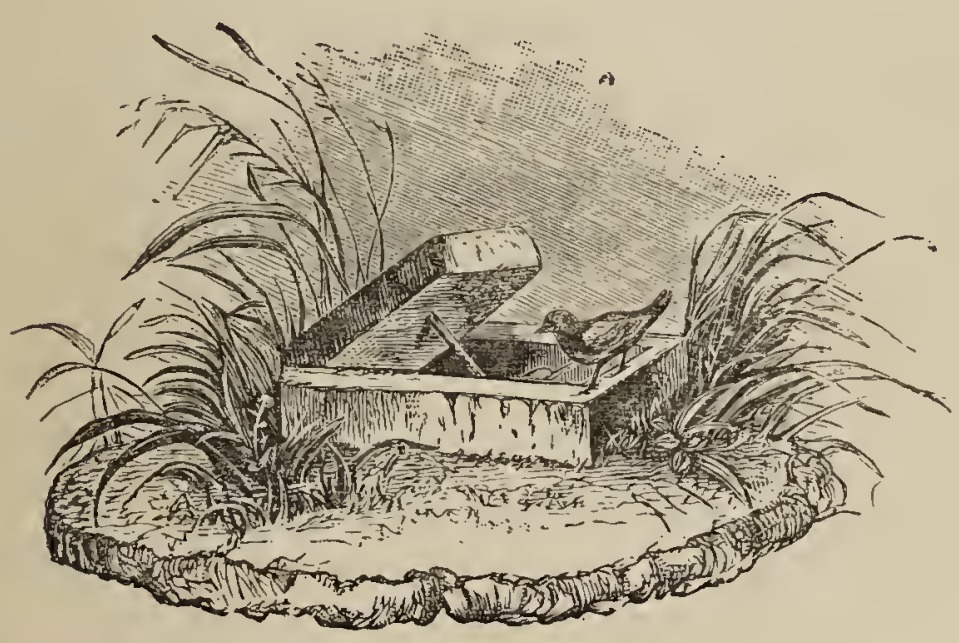




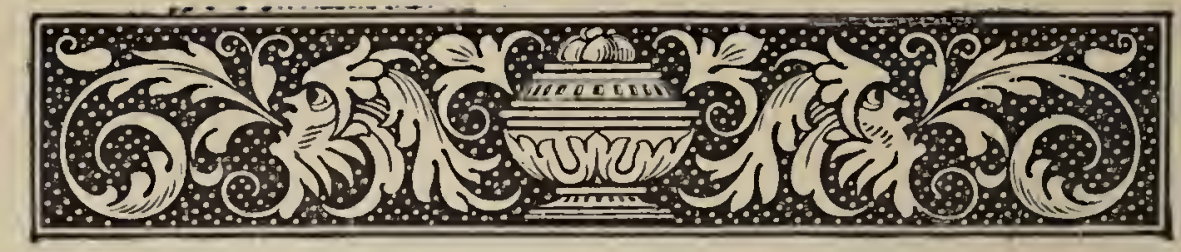

\section{CHAPTER V:}

\section{BIRDS' EGGS.}

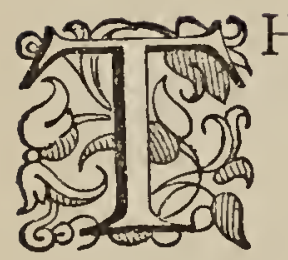

HERE may be some lads who have not collected butterflies, but there can be but very few indeed, if they have lived any time in the country, who have not made some collection, however small, of birds' eggs. Birds'-nesting-by which I mean finding nests, not pillaging, and destroying them-has an irresistible charm for any boy of average pluck and intelligence. The season for it is the loveliest of the year. Everything has just awakened from the winter sleep-

"For, lo, the winter is past ;

The rain is over and gone:

The flowers appear on the earth ;

The time of the singing of birds is come;

And the voice of the turtle is heard in our land; "*

and the boy as he plunges, released from his

* Song of Solomon ii. II, I2 
books, into the budding woods or sunny meadows, finds himself in strange harmony with the world thus awakening to love and joy around him. He feels almost a bird himself, and if he cannot fly he can sing, and add his voice to the general chorus. This is the time for birds'-nesting, and a pleasant thing it is for him to match his wits against the instincts of his feathered fellow-creatures. It is worth while lying a long time among the furze, to wait till the shy, ever-suspicious Stonechat or Yellowhammer unconsciously betrays the secret of her newly-built nursery, or to watch for the Starling to point out which of all the many holes in the tall elm she has taken possession of for the season. The charge of cruelty against birds'-nesting is utterly unfounded-provided, of course, that you pursue it as every brave and tender-hearted English boy should. Remember that one pair of eggs is as good as fifty to illustrate most species, and look much better; and if you take them out of different nests, or even out of the same if there are four or five in it, the parent birds will be neither the wiser nor the worse. It is not the loss of her eggs but of her young which fills a poor bird's heart with terror and despair. You may take an egg out of the nest of a hen without exciting any resentment. but just try to rob her of one of 
her chicks! It is only coarse-hearted blackguards that will think of tearing a nest of eggs, or, worse still, of young ones, out of a bush ; and such young tyrants deserve a sound thrashing for their pains. Would that they always got it! Such a hard-fisted young Roman ploughboy it was that Virgil makes the author of the poor nightingale's lament:-

"Qualis populeâ mœrens Philomela sub umbrâ Amissos queritur foetus, quos durus arator Observans nido implumes detraxit; at illa Flet noctem, ramoque sedens miserabile carmen Integrat, et mœstis latè loca questibus implet."

$$
\text { "Georg.," iv. 510-514. }
$$

"Thus Philomela, lamenting beneath the sad shade of the poplar, All her young ones bewails, which the hand of the hard-hearted ploughboy,

Spying, has ruthlessly torn still unfledged from their nest; but the mother

Weeps the long night, and pours from her seat in the thickspreading covert

Notes of despair which fill all the vale with tuneful complainings."

Happily there is no necessity for causing grief such as this, even in the bosom of a bird, in order to form a collection of birds' eggs. It need involve no cruelty, while it calls forth just those qualities every boy should possess-a keen eyesight to detect the whereabouts of a supposed nest, patience in waiting for the old birds to return and reveal the exact spot, and selfrestraint in helping himself to the treasure when 
actually within reach. Great care is necessary in taking the eggs home and blowing them, and for the following recipe, embodying the latest ideas on the subject, I am indebted to a friend. If you have to climb a tree for eggs, the safest way to descend with them is to have a box with compartments - a cocoa-nut cut in two and hinged with a piece of leather, slung round your neck, makes a capital contrivance. The eggs are dropped into the spaces singly, and secured with cotton wool.

If, after blowing, the egg does not lock quite clean, as often happens if it is a little set, inject with a small syringe a few drops of camphor-water, and shake out the contents when dissolved.

The best way to blow eggs, large or small, is to use the "drill," * after making a small hole in the side with a needle, and then suck out the contents. In case, however, they are a little set, use the blow-pipe in the following way.

First pierce a hole in the side with a needle, and pick away the white membrane, which otherwise will hinder the operation. Hold the egg, hole downwards, between the finger and thumb of the left hand, when some of the white will ooze out. Then put the blow-pipe to your mouth, and blow a strong current of wind just

* To be bought at the naturalists' mentioned at p. 9 I. 
underneath the hole, which will bring out the contents.

If the egg has got dirty by staying in the nest and by coming in contact with the feet of the bird, wash it well with soap and waterusing a nail-brush, if necessary-when it will become as clean and pure as when laid.

With regard to the arrangement of eggs; in large museums, where space is no object, there ought to be no separate collection of them at all. Each species of bird should be arranged naturally, ${ }^{*}$ in company with its nest and eggs; but in small private museums this, of course, is seldom feasible. We made paper trays, fitting into drawers, each tray containing two eggs, the name and locality being neatly written on a separate slip of paper pasted against the farther side of the tray. We never attempted to collect nests-which large museums should do-with the exception of those of one or two species, namely, that of the Long-tailed Titmouse and of the Golden-crested Wren. These were small enough to go in the case with the birds themselves, and formed, with them, charming groups of family bird-life. We often wished for a Kingfisher's nest, which is constructed of bones of the fish upon which the parent birds have preyed; but we wished in vain, for it is an

* See Appendix A. 
exceedingly difficult matter to dig it out uninjured from the hole in the bank where it is built. Some of the nests of foreign birds are most remarkable and curious, such as those of the Tailor-bird and of the Bower-bird; but these did not come within our range. The nests of Humming-birds are also most lovely, and perhaps the very perfection of beauty of bird-preserving would be attained by representing a group of these little winged jewels sitting upon and fluttering around a well-made imitation of some tropical flowering shrub, containing their nests with the eggs.

In the catalogue of our stuffed birds, pp. 4648 , those of which we had the eggs are marked with an asterisk, so that it is unnecessary to draw up a fresh list.

As to books on birds' eggs, it is obvious that any good work upon birds must of necessity contain a description of their nests and eggs, making any work specially on the subject totally unnecessary. There is, however, a little book called "Nests and Eggs of Familiar Birds," by H. G. Adams, which contains good coloured illustrations.

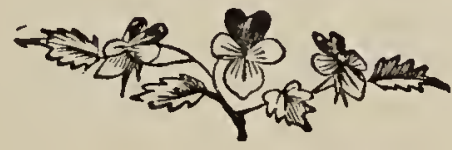




\section{CHAPTER VI.}

\section{SHRAWLEY.}

Fore many of the events of our boy of days, when we were forming our 21. 3 museum, were inseparably connected with Shrawley and its glorious wood, that some account of these is necessary to make my narrative complete. To look forward to a visit to our grandmother, at Shrawley, was the supreme, the crowning happiness of our lives. Her house, the "Wood House," as it is called, stood in a small park on the edge of Shrawley Wood-a forest of between four hundred and five hundred acres, abounding in noble oak trees, with an undergrowth of the small-leaved lime. Imagine what it must have been for a couple of boys like us to have such a domain to roam in! John Wormington, the head keeper, was our firm ally, and one of our choicest pleasures was to accompany him in his rounds, and listen to his innumerable stories about the wood and 
its inhabitants. Next to Joe Wise, we considered him the most remarkable man in the world-as he was, and doubtless is (for he still holds the situation of head keeper), one of the kindest. It was a great thing to see him clean out the well-trap. This is a pit some three feet deep, lined with brick, dug at the junction of several lines of fencing extending a hundred yards or more in various directions into the wood. The pit is covered by a double lid, each half so nicely balanced that the moment any animal, finding itself in a corner, essays to proceed through the narrow alley which it sees before it, it must needs pass over the apparently safe surface of the trap-door. The consequence may be guessed; and scarcely a day came but some wanderers of the previous night were in the well, awaiting the tender mercy of the keepers. Small, indeed, was the measure in which it was meted out to them. Hedgehogs, weasels, stoats, rabbits-it was all the same; and Dante's famous inscription over the gates of Tartarus would have been equally appropriate over that deceitful pitfall :-

"Lasciate ogni speranza, voi ch' entrate."

"All hope abandon, ye that enter here."

And even in these days the result would be the same, for not one keeper in a thousand knows his friends from his foes, and both alike 
perish in one blind and indiscriminating condemnation. The only animals that ever did receive their liberty after making acquaintance with the bottom of that snare were the foxes which occasionally blundered into it. They, of course, were turned down again, for Shrawley Wood was a famous fox cover; and although the hounds, owing to its vast extent, could seldom get them out of it, it was of course a consolation to the county in general, and ourselves in particular, to know they were in it. I only wish that these well-traps were in more general use, and that every gamekeeper could be fined five pounds, plus costs, for every time he was discovered setting or causing to be set one of those abominable contrivances called steel traps. The torture inflicted by this suggestion of Satan is terrible, yet, as it goes on in lonely corners and unfrequented woods, no notice is taken of it. But those who have found, as I have, some poor creature held fast by a couple of broken legs, struggling in vain to tear itself away from the agony of those iron teeth, can form some idea of the anguish endured. The refinement of this cruelty consists in the length of time the victim may be enduring it, for it may be days before the keeper happens to visit that trap in his rounds; and till he does come the miserable creature has to suffer on in its agony, aggravated 
by the inflammation which must accompany the terrible laceration of the trap, and accompanied, no doubt, by the fever-thirst which always sets in under such circumstances. There is not a more glaring inconsistency in the whole administration of justice, than that the law should be down on a man for carrying a fowl heels up, or for driving a donkey with a sore back, and yet take no notice whatever of the immeasurable amount of torture endured every day in the year, all over the country, by the innocent victims of these infernal contrivances.

Not very long ago, in a cover near Lyme Regis, I discovered a poor little hen Blackbird in one of these rat-traps. She was seized by the thighs, both of which were smashed to a mass of inflamed quivering jelly, her beautiful eyes saying as plain as any words, "What have I done to deserve this terrible torture which I have been enduring so many, many long hours ?" I wrote to one of the daily papers on the subject, hoping that the Society for the Prevention of Cruelty to Animals would take it up, but they did not. If vermin has to be destroyed, in the name of mercy let it be caught in a trap that kills outright, or in one in which it can live without pain till knocked on the head; but to allow traps which keep it for an indefinite time in agony is a shame and a sin. 
We were also very fond of going out shooting with our uncle, the Rector, just the man a boy loves to be with, full of spirit and fun, and from him we learned our wood-craft-how to draw the most suspicious Hawk within shot by imitating the cry of its young; how to stalk the watchful Heron as he stood knee-deep in the Lower Pool; how to handle a gun-a most important matter with boys, who ought never to touch one until they have received such training. He showed us the best places for fish and how to catch them, and if we happened to be there in winter, he would generally find us a mount when the hounds met at the Wood House; and knowing, as he did, every inch of the country, by keeping close to him, and following him either over or through everything, we were seldom far off at the finish.

The fishing about Shrawley was superb, and I believe it is still better now, a fine new lake covering many acres of ground having of late years been made in the wood. A rivulet enters the wood at the northern end and forms the Upper Pool; leaving this, and wandering for some distance through ozier beds, it spreads out into the Lower Pool, and then, turning eastward, finds its way to the Severn, which forms the eastern boundary of the wood.

The Upper Pool was our special favourite, for 
it abounded with Perch, which, as everybody knows, are not particular as to who catches them, or how they are caught. Our uncle had a spot cleared for us in the underwood under the oak trees by the edge of the pool. and here we used to spend the summer afternoons, nestling among the ferns and flowers, and pulling the Perch, both large and small, out of the water. If we wanted Jack, we went to the Lower Pool, but they did not run large -about five pounds was the usual weight. But a neighbour kindly gave us leave to fish in his large Pike pools, where we could drift among the acres of water-lilies in a punt, and troll all day. Once I caught a Perch there weighing over two pounds. Better still, however, than fishing. was the sport of lading the brook. Adjoining the gardens of the Wood House was the grove, one of those delicious spots where the foreign Rhododendron, the exotic Pine, and Laurel luxuriate in company with the native Oak, Beech, and Birch. To wander here in May, when the ground was gemmed with Bluebells and Primroses, and the air sweet to the nostril with the scent of Hawthorn blossom, and to the ear with the note of the Cuckoo, Thrush, and Chiff-chaff, was to experience a joy that can never be forgotten. At the head of the grove was a trout pond, fed by a merry, warbling little stream, 
that, on leaving it, wandered a winding way through the grove till it passed into the great wood beyond. It was full of Trout, which ought by rights to have been in the pool above, and once a year or so they had to be caught and returned to their proper home. This was grand fun. Attended by two or three keepers armed with spades and buckets, we, that is, our uncle and our two selves, made our way to the stream. Selecting some bend where there was a likely hole, a stank* of clods was thrown across the stream just above, and another just below. Then we set to work to bale the water out of the hole. Presently the speckled fins of the Trout would be seen as they shot wildly about in terror at the unwonted liberty which was being taken with their privacy, and with gentle yet firm grasp we caught them one after another in our hands and transferred them to the bucket, which, when full, was emptied into the pool above. The Eels were the greatest fun, for to catch an Eel in your hand in the water is a feat which requires practice, but we soon learned the art of passing the middle finger over them and then holding tight, for if you attempt to grasp them in the hand, they are sure to wriggle

* This local term, though not in Walker, is a genuine word, and is probably cognate in its origin with "stand," "stick," "stack," etc. 
out again before you can land them. When one hole was exhausted, the stanks were cut through, and we went on to another. The sport had its penalties notwithstanding, for the nettles stung furiously and the briers tore fiercely; but who cares for such trifles as these? It is astonishing what large Trout are sometimes found in a little stream, where one would think they had not room to turn. I once caught one in this way which weighed two pounds and a quarter: he did not revisit his native pool.

Another great charm which the wood had for us was its butterflies. To see the great Fritillaries, both dark-green and silver-washed, sailing from flower to flower in the open spaces, added yet another charm to this enchanting woodland. The part where they used to be most abundant is now covered by the new lake, and whether the plant they used to feed on in their caterpillar state has disappeared in consequence, or any other misfortune has befallen them, I cannot say, but upon my visits to the same locality of late years not a Fritillary was to be seen. But in those days, when we returned to Woodchester after a summer holiday at Shrawley, we were sure to have many new butterflies, as well as birds, to add to our museum. 


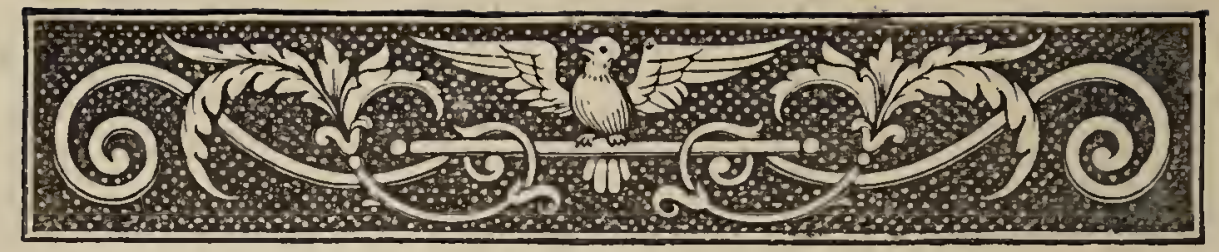

\section{CHAPTER VII.}

“BIRDS OF A FEATHER FLOCK TOGETHER."

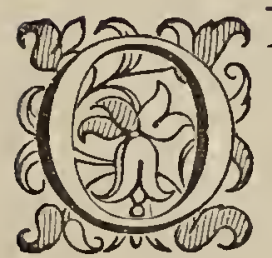

NE summer evening during our first year at Woodchester, as Frank and I were catching roach in the brook -the mill-stream, that is, running along the bottom of the Rodborough Valleya young man of about sixteen, with a younger brother, were fishing on the opposite bank. We struck up an acquaintance, which soon deepened into a friendship. His name was John $\mathrm{H}$ - , and he lived at the picturesque old house close to the church, called the Priory. Before we parted for the evening, he invited us to fish in the Priory pond, the best Trout preserve in those parts. John was a keen lover and observer of nature, and being older than ourselves by several years, was able to help us a good deal in our museum. In bird-stuffing 
" BIRDS OF A FEATHER FLOCK TOGETHER." 65

he was a pupil of Joe Wise, who had made an exception in his favour to his usual rule of not giving lessons. For the next few years we three were the closest of friends, rambling together, gun in hand, over the country, shooting specimens to stuff, and always ready for any adventure which had a spice of risk or danger in it. It was a treat to see John stuff a bird! Although a strongly built, powerful young man, he had a touch more light and delicate than any woman's; in fact, I have often observed that exquisite delicacy of touch is only acquired by the really strong-weak muscles have not the necessary self-control. With him the bird he was stuffing seemed to understand just what was required of it, and to do its best to please him, while with us it did everything it could to oppose and aggravate us. Skilful also was he as a carpenter, and he never begrudged any time spent in helping us to transform rough packing-cases and boxes into shelves and cabinets for our museum.

John dearly loved a joke. One day he came into the museum with a grave and important look, as though he had just made some astonishing discovery. "Just look at this," he said, uncovering a newly-stuffed bird: "did you ever see anything like it?" No, we never had seen anything like that, and we proceeded to 
compare it with the plates in the "Naturalist's Library." There was nothing in the least like it there, so it was evident that John had discovered an entirely new British bird! How we envied him the glory, making particular inquiries as to the precise locality where it was shot, in order that we might search it, in the hopes of shooting the mate! It was about the size of a Hedgesparrow, in fact, a good deal like a Hedge-sparrow about the head and body, but then the tail was so extraordinary-it was bright red. We then turned to Eyton's “ Rarer British Birds," which had been lately invested in; but no, there was nothing like it there. John proposed to call it the Hay-hen, because it was shot near a hayrick; and then, with a glow of pleasure at the thought of our giving its scientific name to a new British bird, we further insisted that it should be proclaimed to the ornithological world as Accentor Fohnii. At this John could contain himself no longer, but, bursting out laughing, gave the tail a touch, and off it fell. In an instant we saw the trick; the rascal had stuck a Redstart's tail on to a Hedge-sparrow's body, and then called the mixture a Hay-hen! Still, no wonder we were puzzled, but I don't think we should have been caught in the same trap twice, and for some time afterwards we regarded with suspicion birds new to us, and took care 
“ BIRdS Of a feather flock together." 67

that their tails were tight before accepting them as genuine.

It was John who taught us to swim-an accomplishment we were not long in acquiring, for we took to the water like young Moorhens, and often in summer time we would go off in a party before sunrise to the splendid pools-one might almost call them lakes-in Lord Ducie's park, and after revelling in the clear deep water, be back in time for breakfast and school. For let not any boy that reads this book think that we did nothing else besides roaming about the country, or that our education was allowed to be neglected for fishing or shooting and bird-stuffing. Nothing of the sort. We were hard at work at our lessons from nine till one every day in the week except Sunday, and no museum or anything else was thought of until the first duties connected with school had been done. However, this arrangement gave us the early mornings, the whole of every afternoon, and generally some time in the evening, after the lessons had been prepared for the next day. Of course there were occasional whole holidays, which we appreciated thoroughly, and the museum was always the richer for them.

And with this union of moderate work and not immoderate recreation, our boyhood sped 
on towards manhood, just as a river speeds towards the sea; in fact, boyhood is to manhcod very much indeed what the river is to the ocean. The merry stream, shallow it may be, but very pure and sweet, flows gaily along through its restraining banks, rejoicing in the rough turbulence and excitement of its ever - varying career, now for a while pursuing a quiet course under the shadow, now bursting out into the joy of fretting rapid and plunge of waterfall, until, as it goes forward it calms down, the banks get less flowery, its waters are taught to bear burdens, and it begins to find it has a work to do in the world-that it is made for other purposes than only to sparkle and warble and be played with. And then at last it finds itself a part of the great ocean, with still heavier burdens to bear, and other storms to endure and larger liberties, kept pure no longer by innocence and ignorance of evil, but by the mysterious gift of salt of a higher and more enduring power.

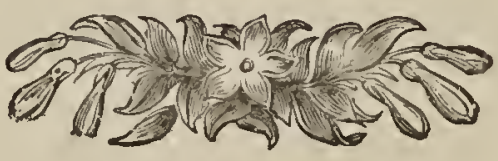




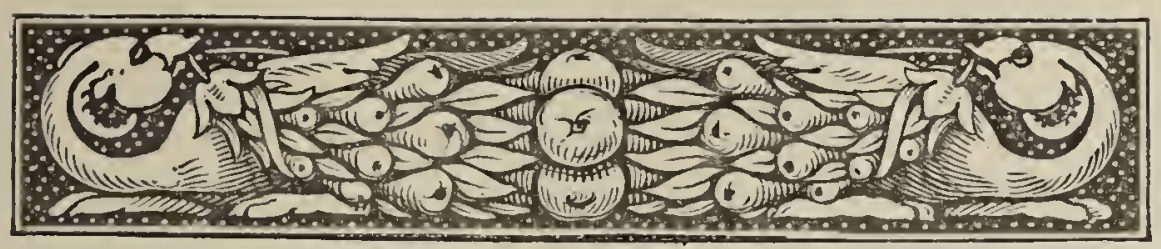

\section{CHAPTER VIII.}

\section{FISHING AND FISH-STUFFING.}

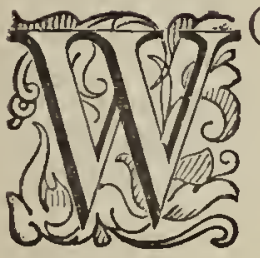

ODCHESTER is, or at all events was, a fine place for fishing, and with the exception of Salmon, most of the ordinary fresh-water fish were to be found within the limits of the parish. This abundance of fishing water was owing to the number of cloth and other mills in the neighbourhood; for each of these had its own mill-pond, and these mill-ponds, being fed by some clear little stream making its way down the hillside to the larger brook in the valley, became admirable preserves. Had any pains been taken with them, these ponds might have abounded with Trout; but they were left to take care of themselves, and, in consequence, the coarser fish, such as Roach and Perch, obtained an easy victory over the shy and fastidious Trout. In fact, as I have already said, there was 
only one Trout pond in the parish-that in the Priory fields-and this did not keep its name long, for Tench and Gudgeon managed to find their way into it, and when the water was let out at last, there were only two or three Trout left. Still, there were plenty of small Trout in the streams, but they were more easily caught with the hand than the hook. There were Pike in some of the ponds, but we did not trouble them, at all events at first, and for a long time our ambition did not soar beyond Roach and Perch.

Just below the orchard in front of our house, to the left, was a deep quiet pool, stocked a little too liberally with Pond-weed, and fringed with Elms and underwood, among which a tangled path ran round it. This, being so near home, became our usual fishing ground, and a pleasant thing it was on a sunny spring day to sit among the Primroses and May blossom, and watch our floats pulled under water by the shy game. At first, as I said, the Roach with which this pond abounded were the objects of our humble ambition, but one day an event occurred which gave us loftier aspirations. While fishing for Roach with our usual caddis bait, we observed a small Jack lying motionless in the water close by. Without considering the weakness of our tackle, we took off the caddis worm, and substituting 
a Stickleback - bamie in the Gloucestershire dialect -- swam it in front of the Jack's nose. There was a dash-a splash-a crash-and we found ourselves standing disconsolate, with a broken rod, minus the line! But "experience teaches," as the proverb says, and thus we discovered that what will hold a Roach won't hold a Jack. In course of time we became ardent Pike-fishers, though I cannot remember catching one weighing over five pounds. One was caught not very far from us which weighed eighteen pounds, and that is the largest I ever heard of in the locality.

Talking of Jack, I once caught one under very curious circumstances at Shrawley. In the lower Shotgrove pool, seeing a long thin Jack lying just under the surface of the water, I tried him with a live Roach, and passed it temptingly before his nose, of which allurement he took no manner of notice. Concluding he was a sleepy Jack, I thought of another way of waking him up, so putting a large Salmon-hook on the line, I threw it over him, and when it touched him struck sharply. Up he came, tail foremost, but making a very feeble resistance, when, to my surprise, I discovered he was totally blind, his eyes having the appearance of being withered away. Whether he had been bullied by a Frog, like the one mentioned by Walton, 
which the Bishops Dubravius and Thurzo saw with their own eyes operated upon by this pitiless Batrachian, I cannot say, but he was as blind as a brickbat, and apparently in the last stage of consumption. Another curious circumstance happened to me when fishing in the Upper Pool at the same place. As the water was weedy, I was using particularly strong snap tackle, with a Roach as bait. Suddenly something seized the bait, and, after a short tussle, I numbered this something among the "landed gentry," when it turned out to be a Carp, weighing over four pounds! It is the only instance I ever knew of a fish, generally so shy, to forget itself and the capabilities of its soft, toothless mouth, so far as to try flesh diet: it must have been uncommonly hard up for a change. The bait, I well recollect, had been taken in good earnest, for the hooks were firm in the back of its mouth, so that it was not a foul-an accident which may befall any fish of an inquiring disposition. So it happened to the largest Perch I ever caught. While spinning with a Minnow, a dead weight, which at first I took for a sunken bough till it began to move away, was suddenly felt on the line. After a long play, I got my friend at last to the surface, when the facts of the case were revealed-it was simply a big Perch hooked by the dorsal fin. I suppose he had come out to 
inspect the Minnow, and, disliking its looks, turned back again, but not allowing for outside hooks, managed to get one of them into his back. It is astonishing the difficulty there is in playing a fish hooked foul in this way; one seems to have no power over him, while his power over you is increased tenfold; it is like riding without reins, the propelling power being unfettered, with the guiding apparatus gone.

At this period of our lives "The Boys' Own Book" was our favourite oracle, and the chapter on fishing, with the correct portrait of every catchable fish, afforded us all the information we wanted, besides a good deal we didn't want. Still, it is just the book which a boy loves for a companion, and he sleeps all the better knowing it is tucked under his pillow, ready at hand should he awake too early. After the fishing department of the book, the swimming came next in our affection. All was eagerly devoured, including even the very indigestible statement that you cannot open your eyes when diving, owing to the pressure of the water; and although our own experience did not confirm this, like all boys, we attributed it to something wrong either with our eyes or the water we swam inas, of course, everything so seriously stated in a printed book must be right.

Our fishing did not contribute much to the 
treasures of our museum, still it did contribute something. Fish are not difficult to stuff, and we soon managed to do it, after our manner, which was as follows:-Having settled which side of the fish we wished to preserve, we turned it over, and made an incision, following the lateral line, on the other side, separating the skin from the flesh, as with a bird. The head had to take its chance, for no art of ours could prevent it assuming the appearance of something between a mummy and a ham. When the first part of the operation was over, with a pair of scissors we cut away all the skin on the side where the incision had been made, so that only half the head and of the skin remained. This, having plentifully deluged it with the solution of corrosive sublimate, we sewed to a piece of stiff cardboard, stuffing the inside with cotton wool as the sewing proceeded. When dry, it was varnished, and the name and place of capture were written underneath, and the specimen hung up in our museum. Perhaps the card might be further adorned with some appropriate painting and dried grasses, but we hal not time for everything. This way of preserving fish, though of course not to be compared with the beautiful works of the art one sees in the fishing-tackle shops, is effective, and quickly and easily done. One thing, however, must not 
be foryotten, and that is, before beginning operations, to cover the side to be preserved with tissue-paper. It sticks firmly as the fish dries, and prevents the scales coming off-which, in the case of the Cycloids, like Carp and Roach, they will do at a touch. When the sewing to the card is finished, the thin paper is easily sponged off, leaving your specimen as perfect as when taken out of the water. The colour on the fins of some species, like the crimson on the ventral fins of Roach, may be touched up with advantage by means of a little paint.

I mentioned just now the word Cycloids, and as I always recommend boys, and girls too, never to pass over a difficult word when reading without thoroughly understanding it, since they may not know exactly what it means, I will explain it.

There are four orders of fishes, determined by the form and structure of the scales. This is the arrangement of Agassiz, and I don't think it will be easily improved upon. His fodr orders are :-

I. PLACOIDS, from $\pi \lambda \grave{a} \xi$ (gen. $\pi \lambda a k o ̀ s$ ), "a broad plate." "The fishes of this order," says "The Gallery of Nature," "are irregularly covered with large or small plates of enamel, sometimes reduced to mere points, like the shagreen on the skin of the Shark, and the prickly, tooth- 
like tubercles of the skin of the Ray." The next time you pick up a dead Dog-fish on the sands, examine its scales, and then you will know what a Placoid is like.

II. GANOIDS, from rávos, "splendour." Fishes of this division have massive, tile-like scales, brilliantly enamelled outside. Fishes of this and the foregoing order may be said to wear their bones outside instead of inside, for their interior skeletons are of cartilaginous rather than of bony structure. In earlier geologic times they were very abundant, but have now almost died out. Sometimes, however, in museums you may see the Bony Pike from North America, which is one of few surviving members of this second order. It looks as if it were enamelled, or covered with hard, shiny tiles.

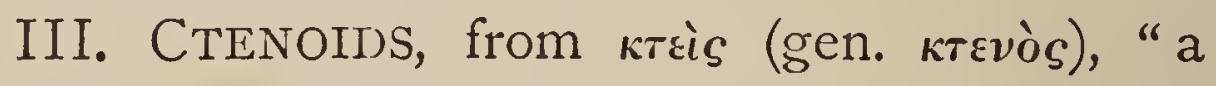
comb." Look at one of the scales of the next Perch you catch, and observe its serrated or toothed outer margin, and you will at once understand the force of the term Ctenoid.

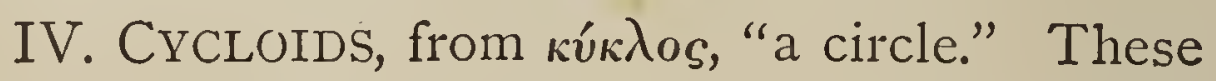
scales are smooth on the exterior edge, and generally very loosely attached to the skin, as you must have found out whenever you caught a Carp or Roach.

These, then, are the four orders of fishes, and it is not a little curious that they severally appear 
to have been introduced into creation in the order in which Agassiz has arranged them. As Hugh Miller so charmingly writes:- "The earliest fishes-firstborn of their family-seem to have been all Placoids. The Silurian system has not yet* afforded trace of any other vertebral animal. With the Old Red Sandstone $\uparrow$ the Ganoids were ushered upon the scene in amazing abundance; and for untold ages, comprising, mayhap, millions of years, the entire Ichthyic $\ddagger$ class consisted, so far as is yet known, of but these two orders. During the times of the Old Red Sandstone, of the Carboniferous, of the Permian, of the Triassic, and of the Oolitic systems, all fishes, though apparently as numerous individually as they are now, were comprised in the Ganoidal and Placoidal orders. The period of these orders seems to have been nearly correspondent with the reign, in the vegetable kingdom, of the Acrogens and Gymnogens, and with the intermediate classes, their allies. At length, during the ages of the chalk, the Cycloids and Ctenoids were ushered in, and were gradually developed in creation until the human period, in which they seem to have reached their culminating point, and they now many times

* This still holds good, A.D. IS8I.

$\uparrow$ Now called the Devonian system.

$\ddagger$ I.e., composed of fish, from i $\chi \theta \dot{v} s$, "a fish." 
exceed in number and importance all other fishes. We do not see a Sturgeon (our British representative of the Ganoids) once in a twelvemonth; and though the Skate and Dog-fish (our representatives of the Placoids) are greatly less rare, their number bears but a small proportion to that of the fishes belonging to the two prevailing orders, of which thousands of boatloads are landed on our coast every day." *

Fish caught at Woodchester or its neighbourhood, most of which were preserved in our museum-

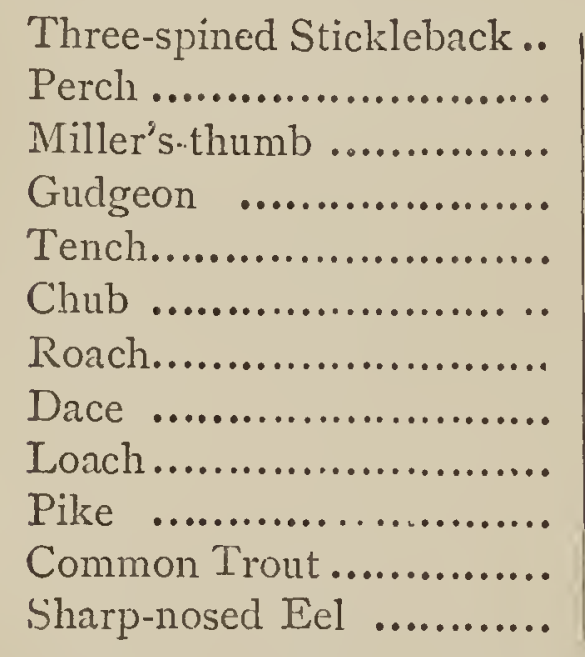

Gasterosteus spinulosus † Perca fluviatilis

Cottus gobio

Gobio fluviatilis

Tinca vulgaris

Cyprinus cephalus

Leuciscus rutilis

- vulgaris

Cobitis barbatula

Esox lucius

Salmo fario

Anguilla acutirostris

Books. - "The Natural History of British Fishes," by Frank Buckland (S.P.C.K.), is by far the best introductory book on the subject. It is full of information most pleasantly told, and every fish is illustrated by a capital woodcut. Crouch's "British Fishes" is a luxury.

* "Testimony of the Rocks," p. 60.

+ Yarrell's nomenclature is given. 


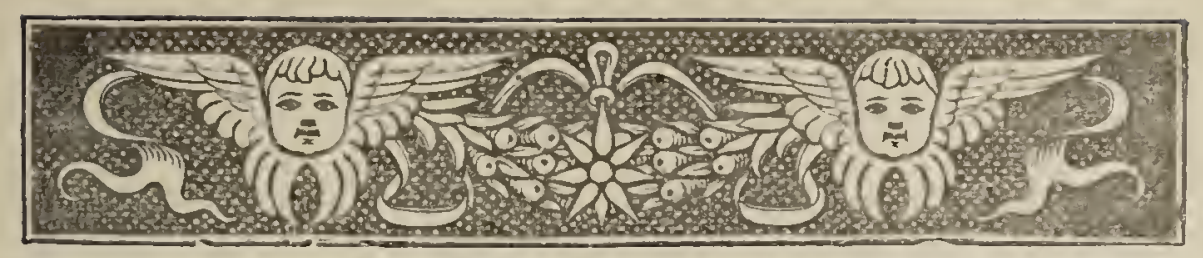

\section{CHAPTER IX.}

BUTTERFLIES AND MOTHS.

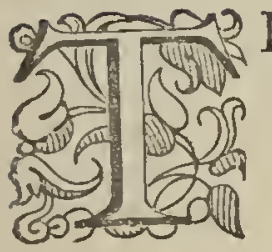

$\mathrm{HE}$ pursuit of butterflies offers so irresistible an attraction, they are so easily kept, and so pretty, that most boys have at some time or other begun to collect them. The end of such coliections is generally much the same. Unless there are proper cabinets to keep them in-and these are expensive-the poor creatures in their boxes and drawers soon get dusty and dilapidated. First the antennæ get broken off, then the wings, the bodies become infested with mites, and at last they are thrown away in disgust.

We were fortunate in inheriting a collection from our eldest brother, who died a few years before our return to Woodchester: it consisted of two cases-one containing butterflies and moths, the other beetles and flies. Still, as our meadows 
and hills furnished a rich variety, we went on making our collection as full and complete as possible. Some species, indeed, we were never lucky enough to catch or even to see on the wing, such as the Bath White, Purple Emperor, Camberwell Beauty,* and White Admiral, $\uparrow$ but most of the not very uncommon species we caught either at Woodchester or Shrawley.

Our collection was headed by a Common Swallow-tail-called common, I suppose, by way of a joke, for it is one of the most local of British insects. I never saw one on the wing in England, though I have caught the Scarce Swallow-tail in abundance, both in the neighbourhood of Quebec and in the south of France, where it is called Le Flambe. The Clouded Yellow, being generally found near the coast, we never observed at Woodchester, though we once caught a fine specimen so far inland as Buckinghamshire. Our own gardens supplied us with most of the Whites, such as the Large, Small, and Greenveined; and our dear old gardener, John Lynn, $\ddagger$ would forgive us rushing through his cabbages if

* When visiting Canada, in $\mathrm{x} 863$, I found the city of Toronto positively swarming with Camberwell Beauties in the month of July, the chrysalises being on every hedge and paling. I have also frequently seen them at Barcelona, and in Switzerland.

+ Since found in abundance in Sussex.

$\ddagger$ The most faithful and affectionate of servants. He died in 1860. 
we were hunting Whites-he well appreciated the attention their caterpillars paid to his vegetables! The Orange-tip, though not by any means common, occasionally made its appearance, and was always looked upon-more especially the female - in the light of a prize. Our single specimen of Wood White, rarer still, was caught in Shrawley Wood. One season the meadows by the brook on the road to Stroud quite swarmed with the Black-veined White, or Hawthorn butterfly, but I never saw it either before or after that one season. Of the showy Fritillary genus we had six species-Greasy, Glanville, Pearl-bordered, Queen of Spain, Dark-green, and Silver-washed, all the larger ones from Shrawley Wood. Our set of the Vanessa group was complete, with the exception of the Purple Emperor; the White Admiral was in our brother's collection, and it was not until last year (I880) that I ever caught or even saw a living specimen.

I have already said that through the northern division of the village a road runs at right angles from the main road in the valley, past the rectory, and straight up the hill, through extensive beech woods, till it opens on to the breezy expanse of Shelsley Hill. These woods, especially the one on the right, afforded famous butterfly hunting, and here we used to find the smaller Fritillaries, Marbled White, Speckled 
Wood, and some of the Skippers. Shelsley Hill itself was an elevated table-land, abruptly terminating on its western side in a steep cliff overlooking the wide valley of the Severn. The whole plain, with the Tump on the edge of the western cliff, reminded one of Cæsar's description of the scene of his parley with Ariovistus, "Planities erat magna et in ea tumulus terrenus satis grandis;" * but the tumulus was precious in our eyes as affording at the proper season a certain find for the Grayling butterfly, besides being a favourite haunt of that world-wide species, the Painted Lady, while both large and small Heaths were plentiful all over the plain. Of the Hair-streaks we had the Brown, Purple, and Green; but the only member of the Lycæna family we ever possessed was the Common Copper. It is thirty-six years, I believe, since the Scarce Copper was captured in England, so it may fairly be counted as extinct, and the foreign specimens which are sometimes purchased as British by unwary buyers, may be distinguished by the form of the orange band in the hind margin of the under side of the lower wings. This, in the true English Copper, is of the same breadth throughout; in Continental specimens it tapers to a point. Our other hills afforded

* "There was a large plain, and in it a mound of earth of considerable size." - "Bell, Gall.," i. 43. 
the more common of the Blues, as well as the Brown Argus, and that little creature with the large name, the Artaxerxes butterfly. So we had every opportunity, with such a neighbourhood for hunting, supplemented by the glorious woods of Shrawley, of making a very fair collection of the British species.

Of the larger and more showy moths we had a tolerable number, but of the little ones, the Tineæ and Tortrices, we knew nothing. They have come into notice since our day, owing to the admirable works of Stainton and Wilkinson on the subject. We had several of the Hawkmoths, including the Eyed, Poplar, Lime, Privet, Elephant, and Humming-bird. I recollect being taken when a very small boy to the studio of Sir Francis Chantrey, in Pimlico, to see a monument to one of my aunts. While the great sculptor was showing his work to the rest of the party, I had espied a Lime Hawk-moth asleep upon a block of marble, and confess, with compunction, that the capture of the insect afforded me far more delight than all the treasures of that wondrous studio.

The Death's-head was a species we never found in those days, though they are by no means uncommon in some localities, and in certain seasons. I know a house in Dorsetshire where the inmates are sometimes positively 
annoyed by the fluttering of these tremendous insects under the verandah on an autumn evening.

As boys, we were of course contented with the ordinary method of laying out and displaying butterflies and moths, but 1 have long been convinced that the method is wrong-wrong because unnatural. We used to go out butterflying armed with a net, a box or two lined with cork, and some pins. Having secured a victim in the net, we gave its body a pinch-two or three if the first did not do the business, rubbing off the down more or less by the process, and as likely as not some of the legs. Then sticking a pin sideways through the thorax, it was transferred to the Dox, and so with the others we caught; and if the pins ran short, two or three butterflies had to share the same one On reaching home, we set them by first pinning them through the back to a piece of grooved cork, and then spreading the wings out and fixing them down to the cork by slips of cardboard, broad at one end and tapering to the other. In this position the insect remained till dry, when it was transferred to the cabinet, and set in a row with others of the same sort.

Now, it is only necessary to observe a butterfiy alight on a flower or on the ground, to convince any one that such a method of display is glaringly unnatural. A butterfly never lies 
on a flower on its stomach, as it is made to do in a case, but stands delicately on its feet, and it is just this standing on its legs which in a dead specimen gives all the appearance of life. Then again, in nature, the wings are never or seldom stretched rigidly out, parallel to the ground, but are raised or deflected at different angles; sometimes-always when at rest-closed outright, showing only the lovely under surface. Lastly, butterflies do not, so far as I have observed, pitch on a smooth piece of cork covered with paper, but on flowers and leaves. So then there are three points to be observed if we are to transfer the insect in all its charms from the forest to the museum: I, it must stand on its legs ; 2 , it must stand with its wings in a natural position; and 3 , it must stand on some object consistent with its habits-all which points can be gained with a little attention and trouble.

First, as to the killing. Give up the fingerand-thumb business altogether, and when you have got your prize in the net, transfer it alive into one of those round chip boxes which you can buy for a few pence the dozen at the chemists'* Directly the lid is put on, and the poor thing finds itself in the dark, it will remain

* For this recipe, and many other valuable hints respecting the preservation of insects, I am indebted to my friend Joseph Anderson, Esq., jun., of Chichester, a distinguished collector. 
perfectly quiet till you get home. Then dip a camel-hair brush in chloroform; just raise the lid, insert the brush for a second or two, close the box for two or three minutes, when the insect will be quite stupefied; remove it to a bottle half filled with sesquicarbonate of ammonia, where it must be left for five or six hours, or even longer if very large. If killed by chloroform only, the limbs becomes rigid so quickly as to hazard the laying it out properly; while if killed with the ammonia, you can leave the specimens all night if you like, and put them in position next day, when they will still be perfectly fresh and limp.

Then as to the setting up. Have nothing to do with slips of card. Having carefully transfixed the butterfly with a long "entomological" pin, fix the pin deeply in a cork setting-board, about three, or for large specimens four, inches square; raise the body of the insect so far up the pin that the regs may stand in a natural manner on the board. Then place four large pins into the cork, as represented in the cut, and from the pin behind to the corresponding one in front attach two threads (i.e., one thread doubled), one passing under the wings, the other over, By raising or depressing the pins, the wings are easily brought to any required angle, and by these means you can impart to the insect the 
exact position and appearance of life. The legs are more difficult to manage than the wings, and

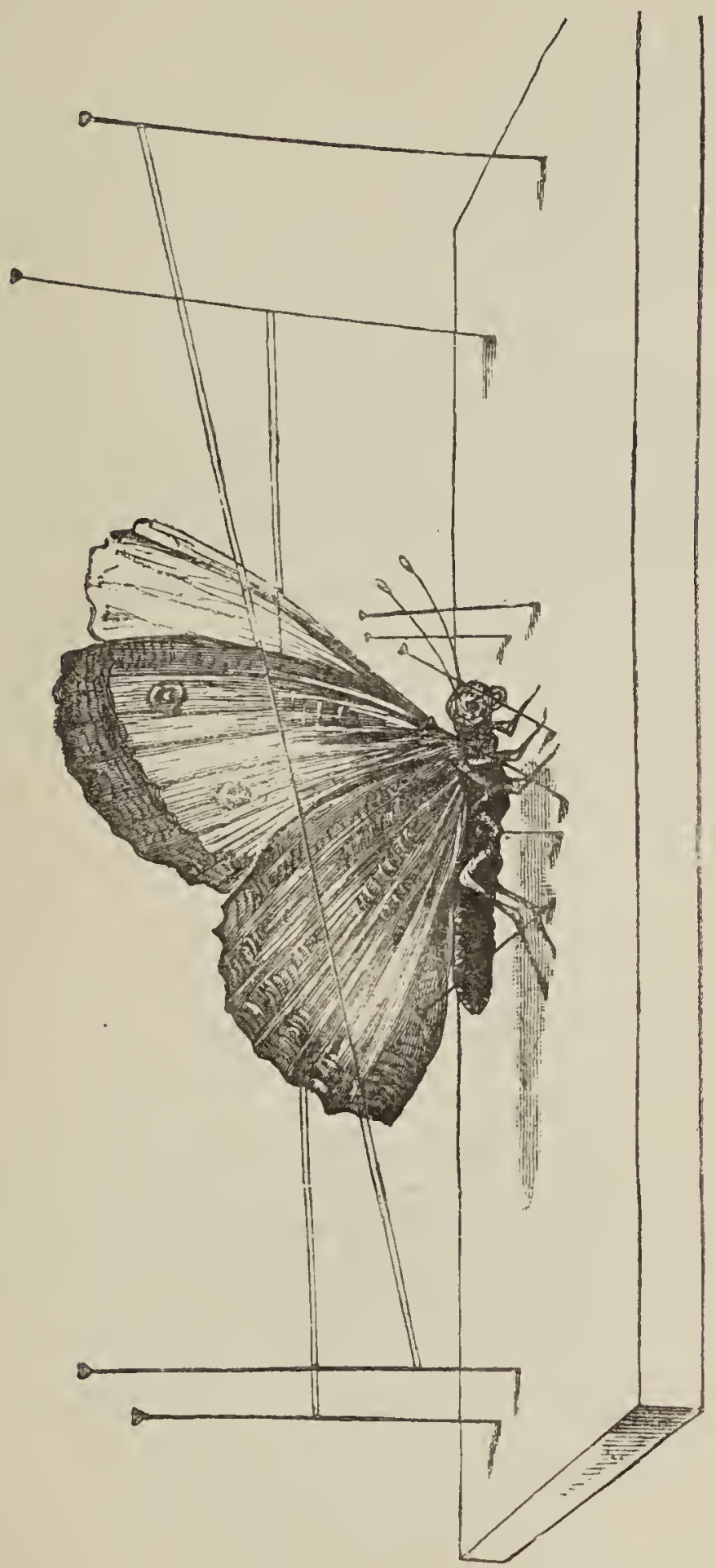

if not moved gently, may come off, and then the specimen is spoilt. 
When the insect is perfectly dry, you can proceed to the third and last stage of the operation, which is to take away the threads and setting pins, and fix the pin which passes through it firmly in an artificial flower or leaf, and then, with a sharp pair of pliers, to nip off the pin as close as possible to the body of the insect. You will then have "a thing of beauty," which, if carefully guarded under a glass shade, will be "a joy for ever." The only objection I can anticipate to this method is the obvious difficulty it leaves in the transfer of a specimen from one collection to another. The flower, or whatever else it may be placed on, must go with it; still, this drawback is small compared with the immense advantage of preserving the insect in its natural attitude. A group of butterflies of the same class, say the Fritillaries, or the Blues, on a group of suitable flowers, some with expanded wings as if drinking in the sunshine, others with them closed as if wishing to escape observation and so showing the under side, has a most charming effect, and would be as suitable for a drawing-room as for a museum. To make such a group entomologically perfect, the caterpillars of the various species should be exhibited upon the plant which they feed on, and the chrysalises suspended in appropriate positions. Any one who has once seen a group 
of butterflies thus arranged will not easily return to the old rank-and-file arrangement, the only plea for which is that it takes up less space. It would be impossible, moreover, to give the minute species-the Tortrices and Tineæ-the benefit of such a natural arrangement. Of the preserving of caterpillars I know nothing, but that it can be done was abun. dantly proved at the Entomological Exhibition at the Royal Aquarium in I878, when most of the butterflies exhibited by Lord Walsingham were accompanied by the caterpillar exquisitely preserved and placed on the leaf which fo: med its food when living.*

\section{LIST OF OUR BUTTERFLIES.}

Swallow-tail

Brimstone

Clouded Yellow ............

Pale Clouded Yellow...... Black-veined, or Hawthorn

Large White .............

Small White ...............

Green-veined White ......

Orange-tip .................

Wood White

Marbled White

Speckled Wood

Wall

Grayling

Meadow Brown.

Large Heath

Ringlet.
Papilio machaon

Rhodocera rhamnj

Colias edusa

- hyale

Aporia cratægi

Pieris brassicæ

— rapæ

- napi

Euchloë cardamines

Leucophasia sinapis

Arge galathea

Pyrarga egeria

— megæra

Satyrus semele

Epinephele janira

— tithonus

- hyperanthus

* See notes on preserving larvæ, p. 27 I. 
Small Heath ..............

White Admiral ...........

Painted Lady

Red Admiral ..............

Peacock

Large Tortoiseshell .....

Small Tortoiseshell ......

Comma....

Silver-washed Fritillary ..

Dark-green Fritillary ...

High-brown Fritillary ...

Queen of Spain Fritillary

Pearl-bordered Fritillary..

Glanville fritillary .........

Pearl-bordered Likeness..

Greasy ......................

Duke of Burgundy Fritillary .......................

Brown Hair-streak.........

Purple Hair-streak.........

Green Hair-streak .........

Small Copper ..............

Azure Blue .................

Little Blue .................

Chalk-hill Blue ............

Common Blue..............

Silver-studded Blue ......

Brown Argus ...............

Artaxerxes
Cænonympha pamphilus

Limenitis sybilla

Pyrameis cardui

- atalanta

Io

Vanessa polychloros

— urticæ

Grapta C. album

Argynnis Paphia

— Aglaia

- Adippe

_ Lathonia

_- Euphrosyne

Melitæa cinxia

- Athalia Artemis

Nemeobius lucina

Thecla betulæ

- quercus

- rubi

Polyommatus phlæas

Lycæna argiolus

_- alsus

—_ Corydon

Alexis

- Egon

- Agestis

- Artaxerxes

Grizzled Skipper ......... Hesperia alveolus

Dingy Skipper ........... — tages

Chequered Skipper ..... - paniscus

Small Skipper ........... - - linea

Large Skipper ..........

The first book for a beginner to get is " British Butterflies," by W. S. Coleman (Routledge), price one shilling. While mastering this, he can be saving up his pocket money for that admirable 
work, Newman's “History of British Butterflies and Moths." Dr. Knagg's "Lepidopterist's Guide," one shilling, is a very useful little book, full of information for young collectors. Entomological pins and all other materials necessary for making a collection of insects can be bought at any naturalist's shop. Messrs. Watkins and Doncaster, Charing Cross, or Messrs. Cook and Son, Museum Street, can be confidently recommended.

\section{MoTHS.}

Green Forester

Six-spotted Burnet-moth ...

Narrow - bordered Fivespotted Burnet-moth ......

Eyed Hawk...................

Poplar Hawk ................

Lime Hawk....................

Privet Hawk

Elephant Hawk

Humming-bird Hawk .....

Broad-bordered Bee Hawkmoth

Goat-moth

Wood Leopard

Buff-tip.

Puss-moth

Emperor

Drinker

Lappet-moth

Scarlet Tiger-moth............

Clouded Buff

Cream-spot Tiger-moth......

Wood Tiger-moth ............

Ruby Tiger-moth ............

Cinnabar-moth

Crimson speckled Footman.
Procris statices

Zygæna filipendulæe

- loniceræ.

Smerinthus ocellatus

- populi

— tiliæ

Sphinx ligustri

Chœrocampe celerio

Macroglossa stellatarum

— fuciformis

Cossus ligniperda

Zeuzera æesculi

Pygæra bucephala

Dicranura vinula

Saturnia carpini

Odonestis potatoria

Lasiocampa quercifolia

Callimorpha dominula

Euthemonia russula

Chelonia villica

Arctia fuliginosa

_- plantaginis

Euchelia Jacobææ

Deiopeia pulchella 
Broad-bordered Yellow Underwing

Large Sword-grass moth ... Buff Arches

Herald-moth

Angle Shades

Gamma-moth

Burnished Brass moth ......

Red Underwing . .

Brimstone-moth

Swallow-tail moth ............

Magpie or Gooseberry moth.

Green Silver-lines

Scarce Silver-lines

White-plumed moth
Triphæna fimbria Calocampa exoleta Gonophora derasa Gonoptera libatrix Phlogophora meticuiusa Plusia gamma

- chrysitis

Catocala nupta

Rumia cratægata

Uropteryx sambucaria

Abraxas grossulariata

Halias prasinana

- quercana

Pterophorus pentadactylus

Books.-The Rev. J. G. Wood's "Common British Moths" (Routledge), price one shilling, is a good book to begin with. The young collector can afterwards go on to Newman's work.

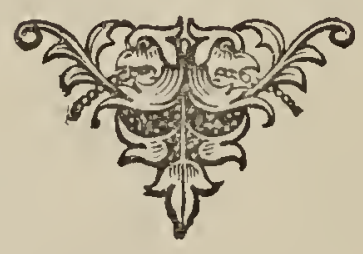




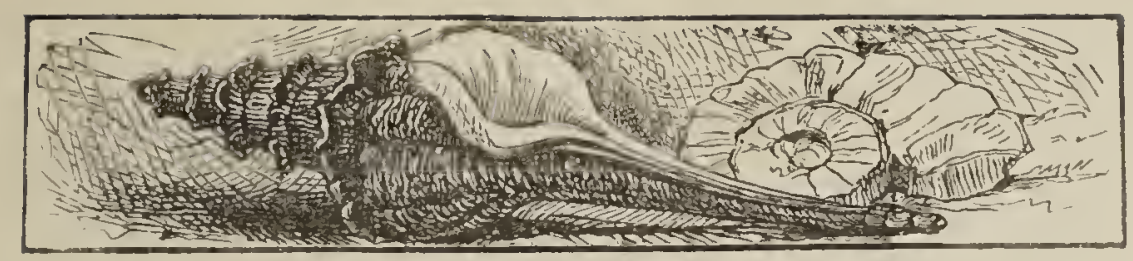

\section{CHAPTER $\cdot \mathrm{X}$.}

\section{SEA-SHELLS.}

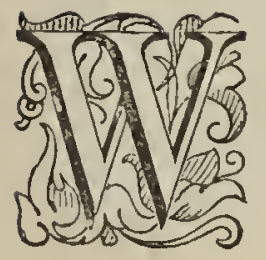

HEN boys are making a collection in earnest, not for the sake of hoarding, but of acquiring information, it is surprising how much kind help they receive from their friends. Everybody has something or other of little interest or value to the owners, but which, if transferred to a boy's museum, becomes of real educational importance. We were continually receiving presents of various kinds, and although we set no great store on what are called "curiosities," we found a place for them if offered, and learned what we could from them. We had a piece of mummy cloth, some wheat, and a bit of bread -rather stale, by the way-taken out of an Egyptian tomb believed to be of the time of 
Joseph; things valueless enough in themselves, but of interest to us, as helping to make the history of that patriarch, and of the sojourn of his family in the house of bondage, a tangible reality, and not merely a bare fact of Bible history. Some flint arrow-heads from the field of Marathon gave us an interest in that splendid victory of Miltiades which our school-books would never have done. An engraved cornelian seal, found among the ruins of Nineveh, was a connecting link between us and the city of Jonah's visit. A model of a North American canoe and of a pair of snowshoes helped us through the geography of the West. So also some bark of the Lace tree: a Vegetable-ivory nut, a fruit of the Mahogany tree, pieces of Coral, and many such like "curiosities" - each taught us something, and served to give some distant part of the world a new interest in our eyes, and increase our little store of knowledge.

But the most valuable present we ever received for our museum was a choice collection of shells from Mauritius. To sort and arrange these was a delightful work for winter evenings, and with the help of Dr. Woodward's invaluable "Manual of the Mollusca," we at length got them into order.

Perhaps from not having had any share in the 
collecting of these shells, perhaps also from the little real information that a mollusc's vacated home of itself conveys, this department of our museum did not hold the first place in our affections. To us they were curiosities, admirable for their beauty of form and colour, rather than a part of the great world of life around us with which we could sympathize, and which had lessons to teach ; and I can truly say that it was not until we were captivated by the study of geology that we began to understand the true place of recent sea-shells in the system of nature. I would advise every young student of natural history to begin with geology, and let the other branches spring from it. On this point I shall have more to say when I come to speak of our fossils; at present I will confine myself to recording what the arranging a quantity of foreign shells taught us.

I must begin, then, by confessing that before the arrival of this collection we were as ignorant of even the rudiments of conchology as of Chinese. The first discovery we made was that the study of shells, apart from their occupantsconchology, in fact-was no longer esteemed a science at all, and that the best authors, such as Dr. Woodward, look upon a shell as part of an animal, and therefore aim at describing, where inssible, the whole animal, and not merely its 
protccting case. Hence the title of his book is not "A Manual of Shells," but of " the Mollusca," giving, in fact, greater prominence to the living inhabitant than to the mere shell, however curious or beautiful it may be. So it was a true instinct after all which induced us to think but lightly of a collection of vacant abodes so long as we knew nothing about the creatures which formed them for their habitation and defence.

We then learned that the molluscan world is arranged in six classes-I., Cephalopoda; II., Gasteropoda; III., Pteropoda ; IV., Brachiopoda; V., Conchifera; VI., Tunicata. Starting from this, we began to sort our collection into six boxes; but when this was done, we were surprised to find the boxes intended to contain Classes III. and VI. empty, one specimen onlyr in box No. IV., only three or four in box No. I., while boxes II. and V. (the former especially) were overflowing. On turning to Dr. Woodward's Manual, we soon discovered the reason, namely, that the Tunicates (Class VI.) have no solid outside shell at all; that the Pteropods (Class III.) are scarcely ever found except floating on the open ocean ; that the Brachiopods (Class IV.) have well-nigh died out of the living creation; and that the Cephalopods (Class I.) have, with a few exceptions, things for shells which we had not recognized as shells at all, but taken them 
for some foreign "curiosities," which had slipped into the collection by accident.

Enlightened by these discoveries, we began to feel our way onward, guided by the meaning of the words employed to distinguish the classes, finding for the first time, the practical value of what little Greek we knew.

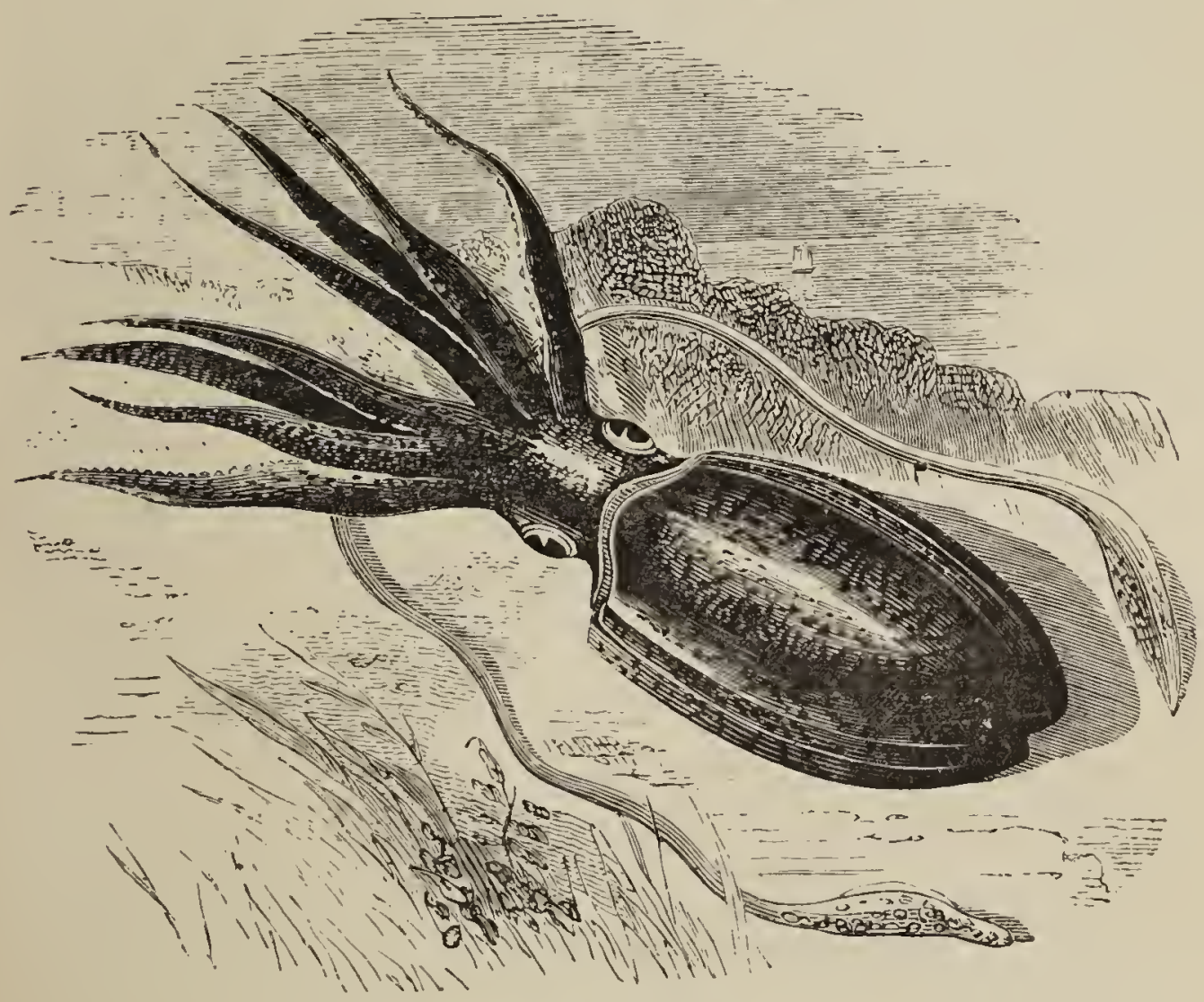

Cuttle-fish.

I. Cephalopoda. Derived from $\kappa \varepsilon \phi a \lambda \eta$, " the

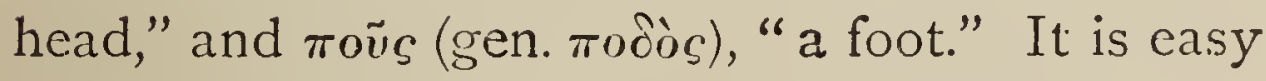
enough to comprehend that this class contains such of the mollusca as have their feet, i.e., their walking and swimming organs, attached to their head. Any picture of a Cuttle-fish explains this 
at once. They possess the further peculiarity of wearing their shells not outside, but inside their bodies, in the shape of a bone. The only members of the family who rebel against this fashion are the Nautilus and Argonaut, who prefer the more general custom of wearing their shells outside, on the decus et tutamen ${ }^{*}$ principle. The Cephalopods have other and most interesting peculiarities. Their powerful feet, or rather arms, are provided with suckers, from which there is no escape save by cutting them away bit by bit; and in some species the head, with its two great eyes, is armed with a beak like a parrot's, capable of inflicting serious wounds on any creature unhappy enough to be seized in that terrible embrace. When I was at Gibraltar in 1867 , a story was told me of a soldier who, while bathing, saw a large Octopus floating into Rosia Bay, and, for the fun of the thing, dived under it, and came up with the beast on his shoulders. In an instant he was clasped by its horrible arms, while the beak began to dig into his flesh. It was with difficulty that he got to land, and the creature had to be cut away piece by piece before the rash -experimentalist could be freed from its embrace. He never played tricks with an Octopus again.

* The motto suggested by Evelyn to prevent the clipping of the larger coins of Charles II., the words being at once an "srnament and protection" to the pieces. 
Our only representatives of this class were some Cuttle-fish bones, a Nautilus, and some odd-looking coiled shells, which we could not make out for a long time, until we discovered they were the interior shells of a species of Cuttle called Spirula lavis.

II. Gasteropoda. Here again the derivation

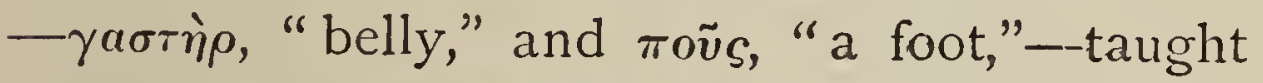

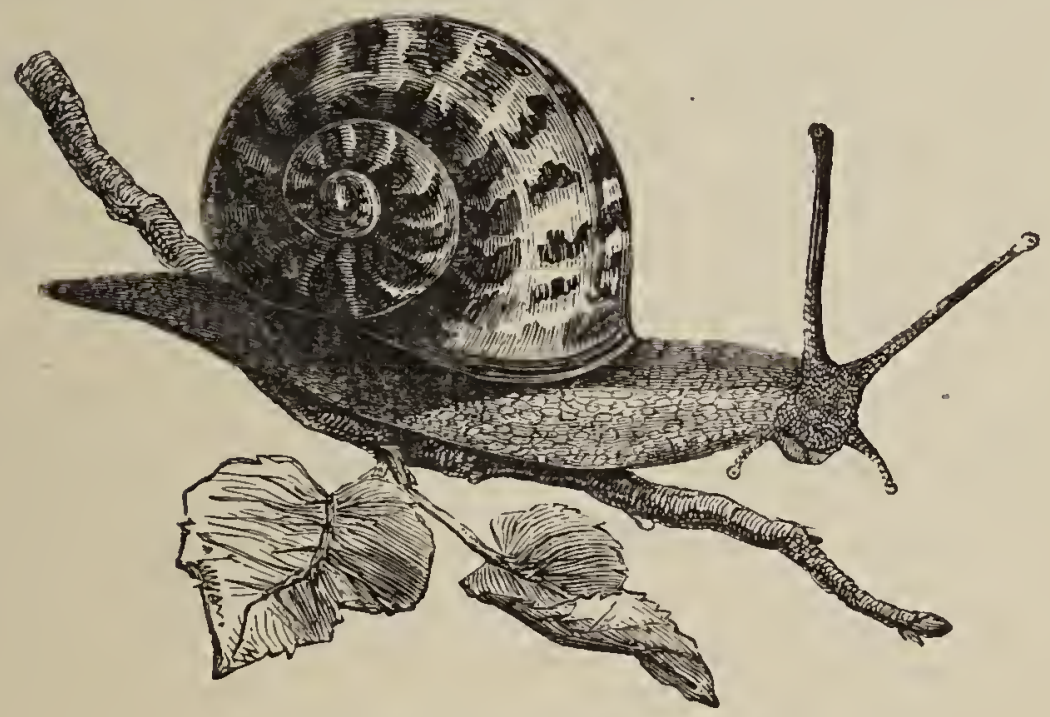

A Gasteropod (Common Snail).

us that molluscs of this class crawl on their stomachs - a performance which the first Snail we could catch in the garden was ready to go through, though more for its own safety perhaps than for our instruction. This class includes all the spiral shells of which we found the greater and by far the most showy part of our collection to consist. We discovered Strombs, though not the large species so dear to lodging-house keepers, but some delicate Seraphs, and a pair 
of Scorpion-shells; some Murices, including a perfect Murex temispina; a Frog-shell; some Spindle-shells, amongst them the long-beaked species, Fusus colus; many Buccina or Whelks, a pair of Auger-shells to wit; plenty of Purples, a Helmet-shell, two lovely Harp-shells, and a grand display of Olives of all shades of colour and variety of pattern. We found also a quantity of Cones, but not a single Pleurotomaria. There are only three specimens known, as we afterwards learned, of recent Pleurotomaria, one of which, "found dead," was shown me by a well-known geologist in his private collection at Scarborough. We had Volutes, Boat-shells, Mitre-shells; Cowries in abundance, including, of course, the common Money Cowry of the Pacific and Eastern seas, of which Dr. Woodward says sixty tons were imported into Liverpool in 1848 , to be again exported for barter witin the natives of Western Africa. Naticæ had we, and Pyramids, Cerites, Melaniæ, and a quantity of Turritellæ; Topshells also, and the pretty Trochi, or Hoopshells, which are world-wide in their distribution. Conspicuous, too, were a pair of Ear-shells-the Ormer of the Channel Islands-with their exquisitely iridescent interiors. There were also many Violet-shells, though, from their extreme fragility, most of them were broken; Limpets 
large and small; and that strange compound shell composed of eight plates, the Chiton, included by Dr. Woodward among the Mollusca. Nor must I forget the Tooth-shells (Dentalium), which, in our ignorance, at first we labelled "teeth of some marine animal."

I shall reserve the land snails, or air-breathing molluscs, for the next chapter, as they formed a distinct branch of our museum.

III. Pteropoda. After hunting through our collection, we could not find a single shell we could conscientiously exhibit as a representative

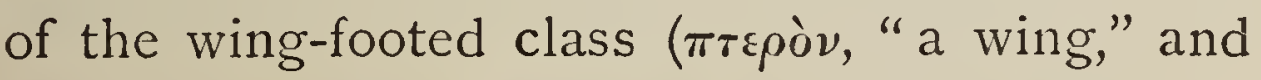

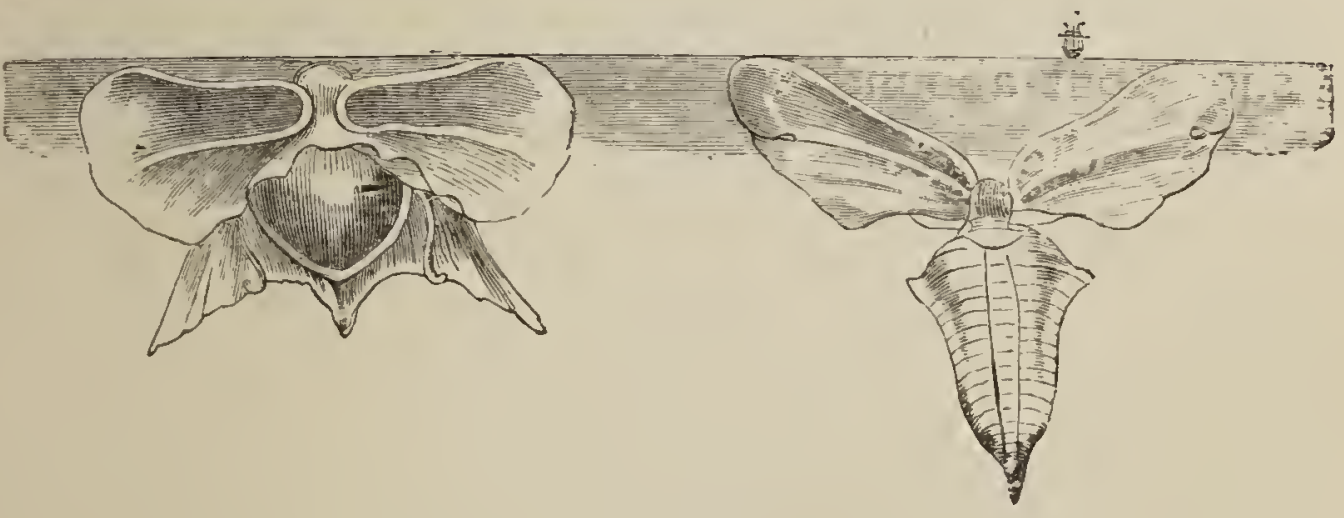

Pteropods.

moṽs). The reason, however, became clear as we read in the "Manual:" "This little group consists of animals whose entire life is passed in the open sea, far away from any shelter, save what is afforded by the floating Gulfweed, and whose organization is specially adapted to that sphere of existence. In appearance and habits they strikingly resemble the 
fry of the ordinary Sea-snails, swimming like them by the vigorous flapping of a pair of fins. To the naturalist ashore they are almost unknown; but the voyager on the great ocean meets with them where there is little else to arrest his attention, and marvels at their delicate forms and almost incredible numbers. They swarm in the tropics, and no less in Arctic seas, where by their myriads the water is discoloured for leagues. They are seen swimming at the surface in the heat of the day, as well as in the cool of the evening. ... In high latitudes they are the principal food of the whale, and of many sea-birds. Their shells are rarely drifted on shore, but abound in the fine sediment brought up by the dredge from great depths." * This description explained the absence of these fragile ocean wanderers from our collection, so we passed on to discover what illustrations it contained of the succeeding class.

IV. BRACHIOPODA (from $\beta \rho a \chi^{\prime} \omega \boldsymbol{v}$, the upper part of the arm, and $\pi$ ov s). Had it not been for one solitary specimen, this division would also have been, like the bellman's map, "a perfect and absolute blank" in our museum. The one shell which represented it was unlike any other in the whole lot, both as to shape and substance. In shape it was like an elongated spoon growing * Woodward's "Manual of the Moliusca," p. 202. 
on a footstalk which, in its dried condition, looked like a withered tendon; in substance it seemed made of horn rather than of shell.* By-and-by, when we began to take up geology, we looked upon this strange form with more reverence than at first, for we discovered it was one of the last lingering representatives of the family which of all shell-fish was the first to appear in creation-a family which had survived every geological change which had taken place from the inconceivably remote ages when the first fossiliferous rocks in Britain were deposited, to the present day; it was the Lingula anatina of the Indian seas. Afterwards we obtained a few other recent Brachiopoda, of which more by-and-by when we come to the fossils.

V. CONCHIfERA. Why this class should alone be called "the shell-bearers" (ко́ $к \eta$, "a shell," and pépw, "to bear"), seeing that all the other classes, save the sixth, do the same, we did not at first understand. I suppose, however, that it is because they are bi-valve, i.e., have two shells, whereas all the others have but one. The oyster is a familiar illustration of a bivalve. In this class we found our collection could amply compensate for its meagreness in the last two; at the same time, these Bivalves were seldom so interesting or so beautiful as the $\dot{G}$ asteropods.

* See fig. p. I67. 
The most attractive were the shells of the Pearl-oyster, which, by the way, is no oyster at all, but an Avicula; and the Pectens, "the butterlies of the sea," of different sizes, some of most beautiful colours; some fine Pinnæ, with the byssus attached, out of which substance a pair of gloves, in the British Museum, has been

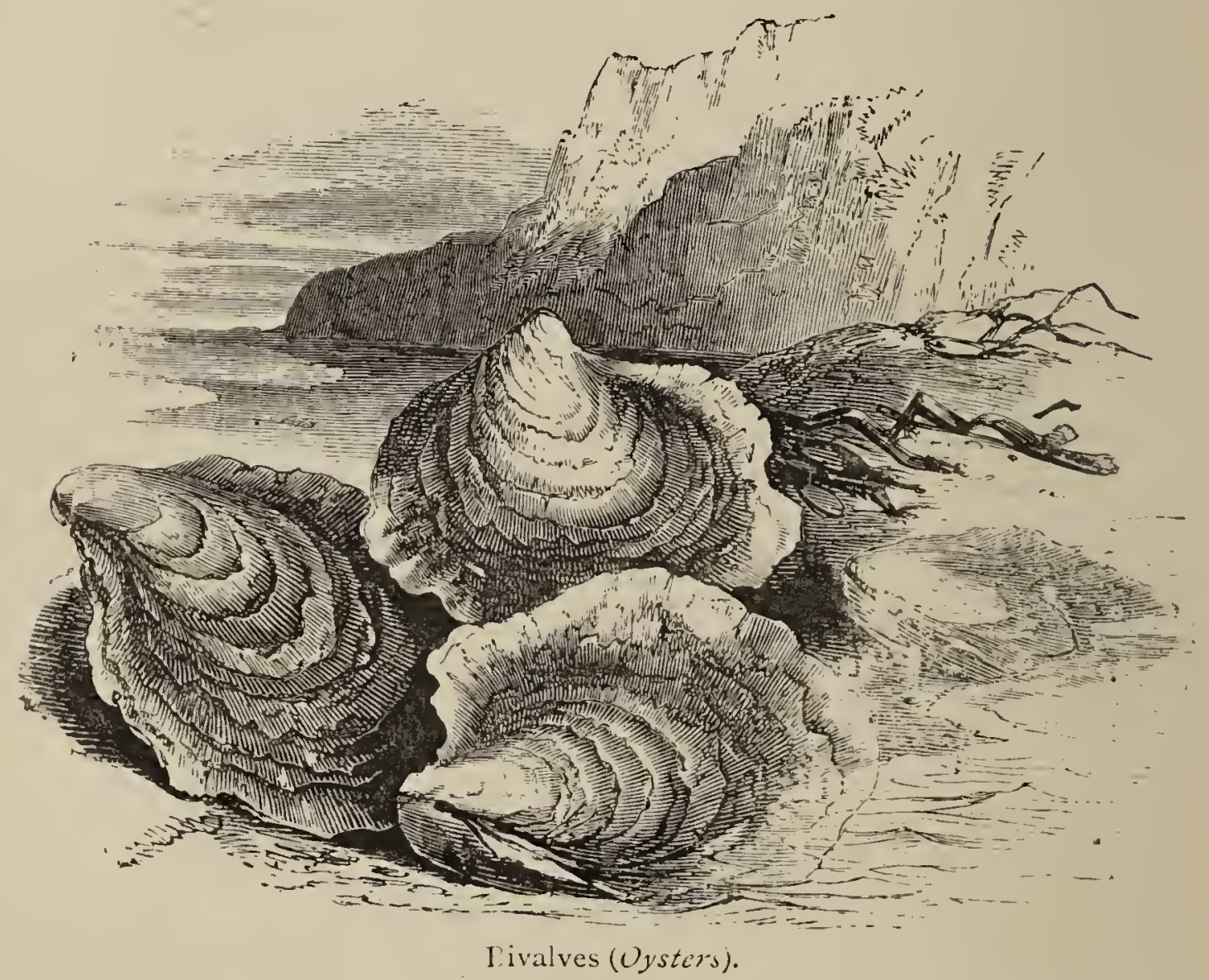

made. We had a splendid Ark-shell, Cockles Venuses, Mactræ, Tellens, Razor-shells, and Pholascs, ${ }^{*}$ whose method of boring into hard rock so long puzzled the naturalist. It is now ascertained that the animal performs the feat by rasping the rock with its shell.

* See fig. p. I05. 
VI. TUnicata (tunica, "a tunic"). As crea tures of this class have no shell whatever, either inside or out, they were not to be looked for in a general collection like ours. I suppose glass models could be made of them, but the only place to gain a good idea of them is an aquarium, where they are most interestisig objects, and might well be taken, without any violent stretch of the imagination, for the pitchers of the water-fairies hung upon the walls of their deep-sea caves, save that the stream of water issuing from the orifices shows that they are sharers with ourselves of the breath of life.

The study of shells is admirably calculated to edify (adificare) the faculty of patient, accurate obser-

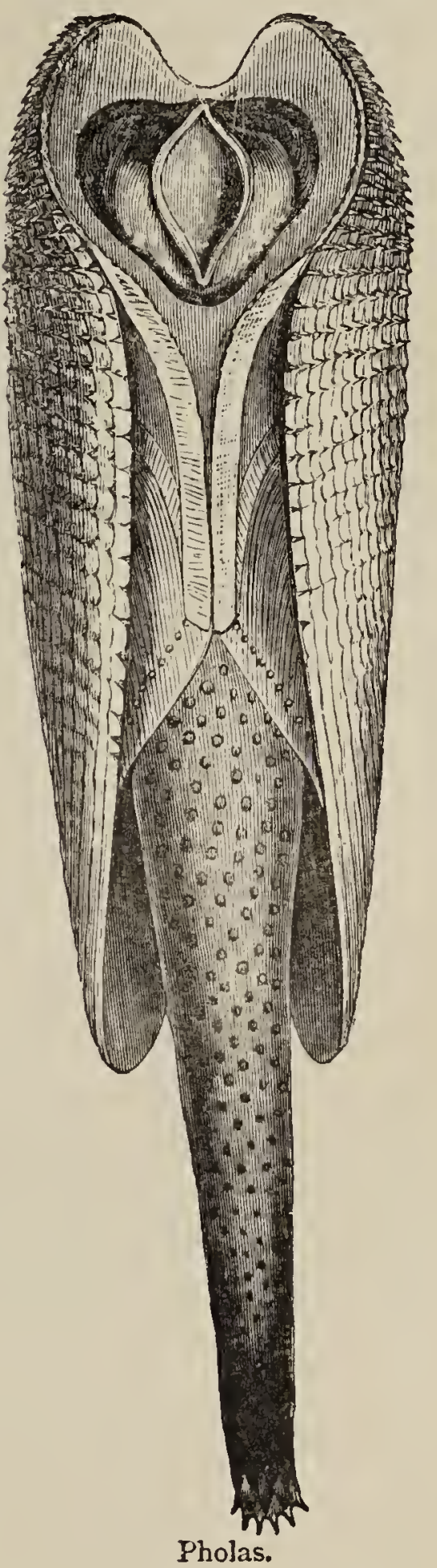
vation and comparison. The points distinguishing one species from another are often so minute 
and delicate, as for instance, the foramina of the Brachiopods or the hinge-teeth of the Bivalves, that the habit of looking for minutest shades of difference calls forth that nicety of observation without which it is impossible to make real advance in any branch of natural science. Then, again, it sweetens geography. Distant localities will no longer appear to the schoolboy a catalogue of dry names, if they are associated with his shells. Let him be given a Paper-nautilus from Amboyna, and if he is a boy worth his salt, he will not go to bed that night until he has hunted Amboyna out in his books, and learned all he can about the island his beautiful treasure comes from. And I can assure him that in the course of arranging and cataloguing our shells, many a distant little island or seldomheard-of sea became as familiar to us by name as the ponds of our own parish. The information thus acquired lies deep and indelible in the memory, while much that is obtained by painful and laborious processes fades away with disappointing swiftness.

Books.-There are, I believe, several useful little books introducing the subject of sea-shells to the beginner. Professor Duncan's "The Sea-Shore" (S.P.C.K.) is sure to be good, but I have not read it. Gosse's "A Year at the Shore" is 
charming; but I should advise all beginners to start at once with Dr. Samuel Woodward's "Manual of the Mollusca." This work, as its author tells us, was six years in compiling, and it is a perfect treasury of molluscan and geological knowledge. Once, when fossil-hunting in Catalonia-examining, in fact, the Turritella beds of Montjuich, at Barcelona, I found a couple of Spaniards similarly engaged, and comparing their specimens with a book they carried with them. Entering into conversation with them, they showed me both fossils and book, when, to my surprise, I found the latter was the French edition of my late friend's Manual.

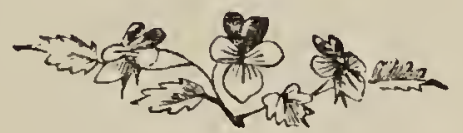




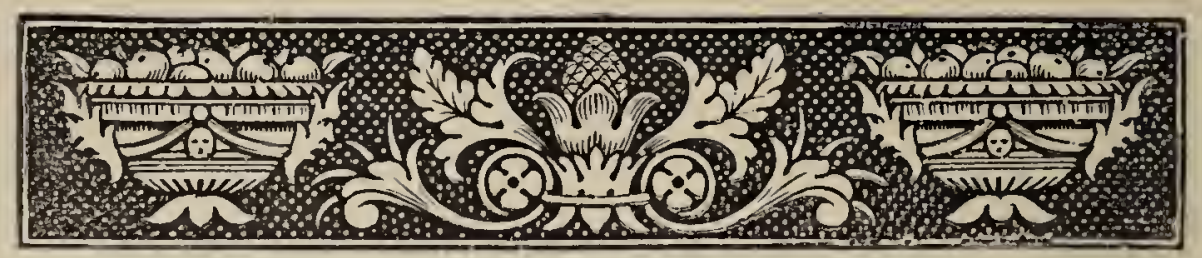

CHAPTER XI.

FRESH-WATER SHELLS.

की man 0 ORGEOUS as many of our foreign sea-shells were to look upon, we really took more interest in the humble land-shells of our own district ; for these our own eyes had discovered, our own fingers had captured, and our own observation had taught us something about the manners and customs of the beings who lived in them. A calcareous district like the Cotswolds was amply provided with snails-too much so, John Lynn, our gardener, thought; but to me at that time, as well as in later life, they proved an unfailing source of interest, and the object of many a pleasant ramble among the hills and woods. When summer days are gone, summer birds departing, and summer flowers fading; when butterflies are getting scarce, and fish ceasing to bite; then it is that snail-hunting begins. 
In the autumn the snails have completed their year's growth, and are at their full size and beauty. One advantage of hunting for them is that it goes hand-in-hand with other pursuits, and fills up any odd time not better engaged. It gives an additional object for country walks, and you cannot go fossil-hunting or fern-hunting without being drawn into the very localities where the best land-shells are found. Sometimes, too, when travelling, if one has to wait at some out-of-the-way junction or station, the time passes more quickly and profitably if spent in a search in some neighbouring lane or pond for molluscs, than in dawdling upon the platform, reading the advertisements.

The science of snails is not difficult. They lie in two self-evident divisions- $A$, the water molluscs, and $B$, the land molluscs.

A. The first class of the fresh-water shellfish belongs to the Conchifera, or Bivalves; the second to the Gasteropoda, or Univalves. The former are further arranged in three families: I., the Cycladidæ (Sphæriidæ of Scopoli)-both terms referring to the subglobular form of the shell ; II., the Unionidæ, or fresh-water Mussels ; III., the Dreissenidæ.

I. Cycladide. No one need have any difficulty in finding the Horn-coloured Cyclas (Cyclas cornea); the difficulty would rather be to 
find a pond or stream which does not contain it. The Capped Cyclas (Cyctas lacustris) is almost as common, and in confinement it has been observed to sink from the surface of the water to the bottom, " not suddenly, but gradually, as if it were lowering itself by a thread attached to the surface of the water." In fact, it appears to be a family feature of the Cycladidx to spin a thread or filament in order to moor themselves to the water plants among which they spend their lives. Sometimes, when looking for a Cyclas, which is about half an inch long, one meets with a shell of much the same appearance, only about half the size. This is the Peashell (Pisidium), a division of the Cyclas family, of which there are six British species; the distinction between the two genera being that Cyclas has only one respiratory syphon, while Pisidium has two.

II. UNIONIDE. The shells of Unios, and the closely allied Anodons, made a grand show in our museum, especially those of the Swan-mussel, which is sometimes eight or even more inches in breadth, and from four to five inches long. The interior has all the charming iridescence of mother-of-pearl. One of the Unios, Unio margaritiferus, is the Pearl-oyster of Britain: it is, however, a northern species, and we never recognized it in Gloucestershire. Bede, in the 
description of Britain with which he prefaces his "Ecclesiastical History," says of our island : "It has the greatest plenty of salmon and eels; seals are also frequently taken, and dolphins, as also whales; besides many sorts of shell-fish, such as muscles, in which are often found excellent pearls of all colours-red, purple, violet, and green, but mostly white. There is also a great abundance of cockles, of which the scarlet dye is made; a most beautiful colour, which never fades with the heat of the sun or the washing of the rain, but the older it is, the more beautiful it becomes." * We can only conclude either that the true breed of these muscles was exterminated for want of an Anglo-Saxon "Pearl Preservation Society," and met the fate which threatens our own prized "natives," or that we have lost the art of producing "excellent pearls," for British pearls nowadays are not worth the fishing for.

III. DREISSENIDA. This family, named after M. Dreissens, a Belgian druggist, has only one representative in this part of the world, but that one is a tyrant and usurper. He has come and quartered himseif upon us without the slightest invitation, having got his passage from Eastern Europe by some low, underhand contrivance. It is believed that he came as a stowaway in a timber ship, and having once obtained a * Bede's "Ecci. Hist.," Bk. I. cl. i. (13ohn's translation). 
footing in our docks and canals, has treated them as if they were exclusively his own. As the presence of this invader was not noticed till the year I 824 , it may be his migration took place shortly before that period; but once arrived, he proceeded to colonize the country he had usurped with the utmost alacrity. By 1833 he had penetrated into Scotland, four years later had got as far west as Birmingham, and then may be said to have fairly conquered Britain. Not content with lining the beds and sides of our canals and reservoirs-a liberty which might have been pardoned, seeing it did no great harm to any one-he must needs intrude into the very water-pipes and cisterns, and has even been found in the streets of London after they have been flushed with water from the New River.* The only invasion which can at all be compared with this is that of the infamous Canadian Waterweed, Anacharis alsinastrum, which, introduced as an honoured guest into our aquaria, proceeded to choke up our canals and ponds, and make itself a national nuisance.

B. The second class of our fresh-water shellfish belongs, as I said, to the Gasteropoda, or Univalves, and is arranged in two orders- $(\alpha$ the Comb-gilled (Pectinibranchiates), and (b) the Lung-gilled molluscs (Pulmonobranchiates).

* Jeffrey's "British Conchology," vol. i. p. 48. 
(a) I. Of the former there are three families-.. the Nerites (Neritida), the Marsh-shells (Paludinide), and the Valve-shells (Valvatidee). The River Nerite is a lovely little object, and more like a. sea-shell than any other inhabitant of our rivers. Our specimens came from the Thames at Richmond, though I discovered my first specimen in, of all places in the world, a London drawingroom! As I was leaning out of the open window, I saw in the stucco, which happened to be a little broken, something which looked like a shell. A few digs with a penknife separated it from the sand and lime in which it was embedded, and I then found that it was a Nerite. This happening in London, I concluded that the sand must have been taken from the Thames, whereupon the next time I was at Richmond I searched in the bed of the river close by the bridge, and there I found enough Nerites to: make a good series for our museum. In displaying them, the operculum, after taking out the animal, was restored to its original position in some of the specimens; in others it was gummed at the side of the shell to which it had belonged, the under side up, so as to show the process by which it is attached to the animal.

2. The marsh-shells (Paludina) are easily found, especially the Common Marsh-shell (Palidina vivipara), which might almost pass for a 
Periwinkle, save that the shell is much thinncr. Our series, ranging from the youngest to the

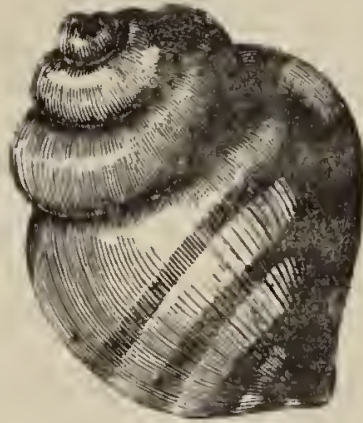

Paludina vizipara, and Operculum.

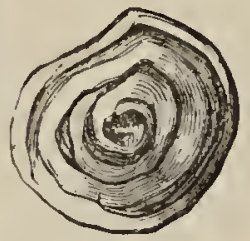
fully grown quite an inch and a half long, made one of our prettiest cards. We had also a card of the Tentacled Bithinia ( $\beta$ utòs, "a deep pool"), obtained from the same ditches as the Marsh-shells, and resembling them, except that they are not one-tenth their size.

3. The Valve-shells (Valvatide) are also a very common species of water-snail, and may be found in most fish-ponds. They are rounder and more like land-snails than the two preceding. There are two native species.

(b) Passing to the lung-gilled molluscs (Pulmonifera), the first genus that we meet with is that comprising the curious Coil-snails (Planor-

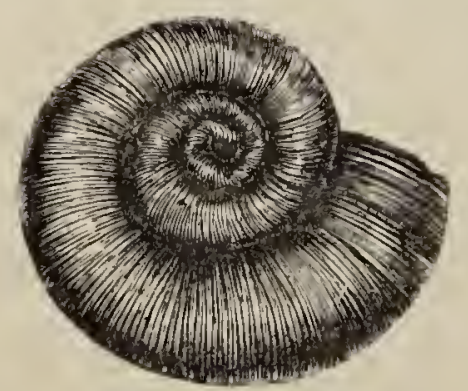

Planorbis corneus. bis), of which no less than eleven species are British, though we had only the common ones - the large Horny Coil-shell (Planorbis corneus), the Flat Coil-shell $(P$. vortex $)$, and the Round-spired Coil-shell (P. spirorbis). The first of these is an exceedingly showy water-snail, and looks well in an 
aquarium. After these come the Bubble-shells

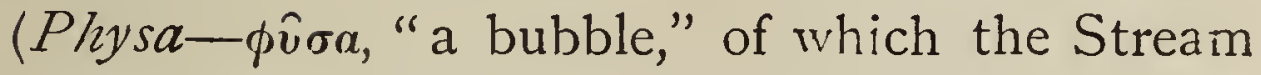
Bubble-shell (Physa fontinalis) is one of the commonest of all our water-snails. These are followed by the Pond-snails (Limncea- $\lambda i \mu \nu \eta$, "a pond"), comprising eight species, of which we had the two commonest-the Wandering Mud-shell (Lim-

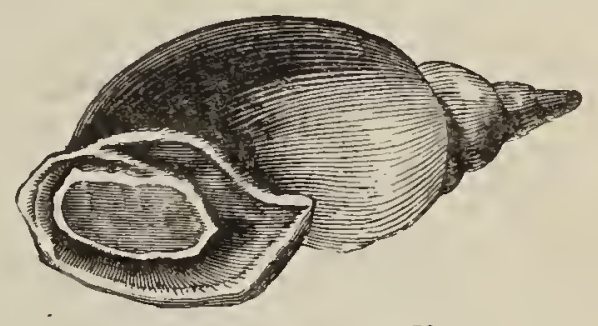

Limnaa stagnalis. nea peregra) and the Lake Mud-shell (Limnea stagnalis). The group is closed by the fresh-

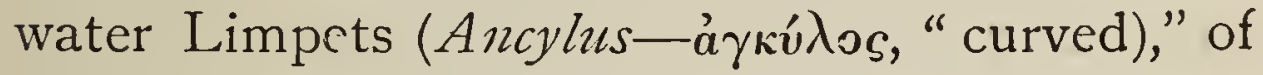
which hundreds may be found in most brooks, sticking to the stones, just as their sea cousins stick to the rocks of the shore. They are complete miniatures of the marine species.

This closed our list of fresh-water shells, but the knowlecige of their presence lent an additional attraction to the streams and ponds of our district. Sometimes, when the fish were sulky and would not bite, we would put up our rods and take home a harvest of water-snails, and, by practice, were soon able to detect the presence of a species new to us, or any unusual variety.

In displaying our British shells we used pieces of cardboard four and a half by three and a half inches. This is quite large enough for all ex- 
cept the very largest, such as the Unios, and some few of the land-snails, to which it is easy to give a tablet just double the size. These cards or tablets fitted into drawers, and made an imposing appearance; and I am sure that many, who laughed on hearing we were fond of snails, when they saw our neat and orderly collection, comprising as it did more than onehalf of the British species, exchanged their look of ridicule for that of surprise and admiration. While as for ourselves, if the pursuit of these humble creatures did nothing else, it taught us to take an interest in the lower grades of animal life as well as in the higher, and to look for beauty and perfection wherever the humblest fellow-sharer of the breath of life was to be found.

List of Fresh-Water Shells in our Museum.

Conchifera, or Bivalves.

Horn-coloured Cyclas ... Cyclas cornea

\begin{tabular}{ll|l} 
Capped Cyclas & ............ & $\frac{\text { lacustris }}{\text { River Pisidium }}$ \\
Pisidium amnic.......
\end{tabular}

Pisidium amnicum

Swollen Mussel

Unio tumidus

Painters' Mussel ............

Swan Mussel

- pictorum

Zebra Mussel

Anodon cygnea

Dreisséna polymorpha

Gasteropoda, or Univalves.

River Nerite

Common Marsh Shell ...

Tentacled Bithinia

Stream-valve Shell
Neritina fluviatilis

Paludina vivipara

Bithinia tentaculata

Valvata piscinalis 


\begin{tabular}{l|l} 
Horn coloured Coil Shell & Planorbis corneus \\
Flat Coil Shell ........... & - vortex \\
Flattened Coil Shell ...... & marginatus \\
Keeled Coil Shell ........ & - carinatus \\
Round-edged Coil Shell... & - spircrbis \\
Stream Bubble Shell ...... & Physa fontinalis \\
Moss Bubble Shell........ & - hypnorum \\
Wandering Mud Shell ... & Limna peregra \\
Ear-shaped Mud Shell ... & - auricularia \\
Lake Mud Shell ........... & - stagnalis \\
Marsh Mud Shell ........ & - palustris \\
Truncated Mud Shell...... & - truncatula \\
River Limpet ............... & Ancylus fluviatilis \\
Lake Limpet .............. & - lacustris
\end{tabular}

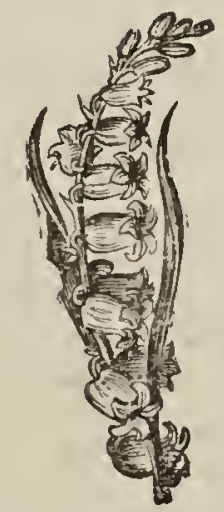




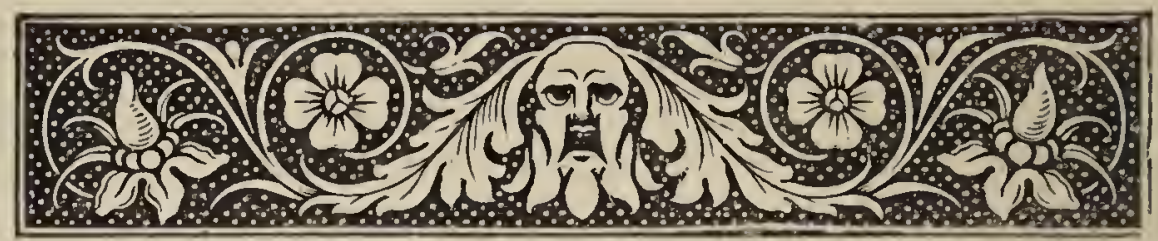

\section{CHAPTER XII.}

\section{LAND-SHELLS.}

(4) $\mathrm{N}$ another box, fitted with shelves, we kept our land-sheils, which made an impressive display. The first of the five families into which these are grouped for the convenience of classification is : I., Limacidæ, the Slugs. These we did not profess to cultivate, but we had a tablet of the shells of that remarkable link between them and the snails - the Testacella. One day, the post brought us a boxful of these creatures from the neighbourhood of London, and it was the first time we had seen them. They might easily be mistaken at first sight for Slugs, but a closer inspection reveals a little apology for a shell on the end of their tails, an adornment of which no thorough-bred Slug can boast. It reminds one of those little bonnets which a few years 
ago ladies used to stick on the extremity of their chignons. They differ from the true Slugs, moreover, in another important feature, in that they are exclusively carnivorous in their diet, whereas Slugs are staunch vegetarians, as every gardener knows to his cost. Not very long ago a gentleman assured me he had caught these same Testacellas devouring his plants, and, when I expressed astonishment at the news, offered to convince me by ocular demonstration. Whereupon, the next nice moist evening, we sallied forth into his garden, armed with lanterns and scissors. Common Slugs were met with and snipped asunder in plenty, and at last my friend exclaimed, "Here is one of your Shell-slugs eating the Pyrethrum!" Hastening to the scene of the robbery, sure enough there was a big Testacella, half on the plant in question and half on the ground. "Now, are you convinced ?" said my friend, triumphantly. "Not quite," I answered, taking up the supposed culprit, when, to my friend's amazement, we saw that the tail of the Testacella was upon the Pyrethrum, and his head in the earth, and drawing this out, there in his mouth was a good-sized worm, which he had half swallowed! His character was cleared! At the same time, if Testacellas will look so very much like Slugs, and will go hunting in their 
sompany after dark, even though it be after different game, they must not be surprised if they share their fate. As for the specimens sent us, we killed the animals and kept the shells, which is the only thing to be done with such creatures. Perhaps it would have been better to make wax models of the animal, and then stick on the shell in its natural position; but this was beyond our powers.

Leaving the Slugs, we come next to the Snails comprised in the second family, Helicidæ. It is divided into eleven genera, viz. I., Succinea; II., Vitrina; III., Zonites ; IV., Helix ; V., Bulimus ; VI., Pupa; VII., Verti'go; VIII., Balia ; IX., Clausilia; X., Cochli'copa ; XI., Achatina.

I. The Amber-snails, Succinea (from succincus, of or belonging to succinum, "amber"). These are generally to be found on the leaves of bulrushes and other aquatic plants, about a foot from the surface of the water; and it is said that they ascend or descend the leaves according to the rise or fall of the water, and so always live at the same distance from it. It is also said that they regulate their movements according to the weather, and therefore act as natural barometers, ascending high upon the leaves of the water plants at the approach of fine weather, and descending close to the water when rain is coming. How far either of these statements is 
in accordance with facts, is an interesting subject for further observation. The shell is a most delicate and beautiful object, semi-transparent, and as fragile as the thinnest glass. There are three species, of which we had the two commoner. The Oblong Amber-snail (Succinea oblonga) is rare.

II. The Glassy Snails, Vitrina (vitrum, "glass"), have a beautiful greenish glassy shell, very delicate, easily distinguished by the absence of the umbilicus, or central cavity, which most of the spiral shells possess. They are said to be not only carnivorous on occasions, but fierce. Mr. Tate, in his useful little manual, mentions the experiments of M. le Dr. Baudon, who observed them attack and devour some fellowsnails, kept under the same bell-glass, in the most heartless manner. The only apology I can think of for such conduct is, as Waterton has remarked, that you cannot judge of the real habits of an animal from its conduct in captivity; but this I am afraid will fail, for Mr. Gwyn Jeffreys says he once saw no less than seven green Glass-snails (Vitrina pellucida) "busily engaged in feeding on a scarcely dead worm, which was faintly writhing about, and endeavouring in vain to get rid of its tiny assailants." Although spoken of as a common Snail, I can only remember once meeting with 
it, so I conclude I did not know where to look.

III. The Snailets, Zonites or Helicella. Of this family, which is still more nearly allied to Helix than the last, there are nine species, of which we possessed the Cellar Snailet (Zonites cellarius); the Garlic Snailet ( $Z$.alliarius), which possesses the unenviable faculty of emitting a garlicky odour when irritated; and the very common Dull Snailet ( $Z$. nitidulus).

IV. The true Snails, Helix ("a coil"). This is the largest and most flourishing family of all the land-shells, comprising no less than twenty-four species, and among them our old friend of the gardens, better known than loved. Among the more interesting of those which adorned our

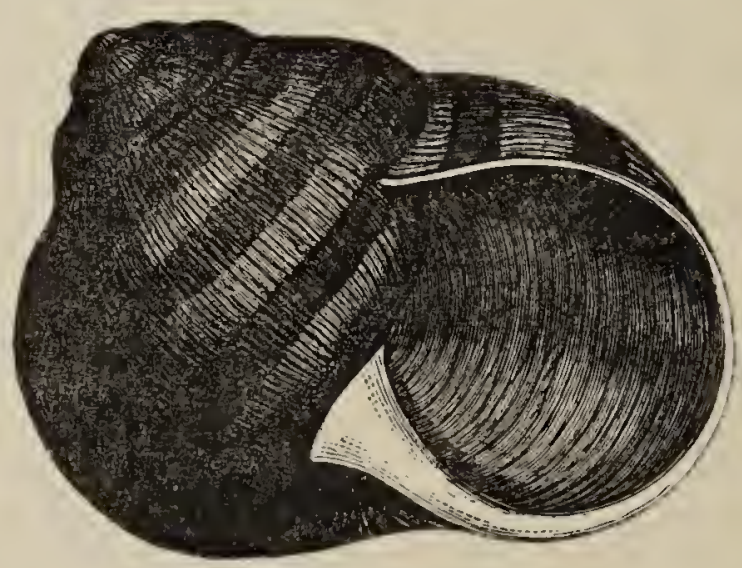

Apple-snail:

museum were: I. The Apple-snail (Helix pomatia), so called from its apple-like shape, its specific name not being derived from pomum, "an apple," but from $\pi \tilde{\omega} \mu a$, "a lid or cover," having 
reference to the remarkably strong and solid plate which it secretes to keep out the weather during its winter sleep. This is the largest of our native Snails, and makes a favourite dish in some parts of the Continent, but I have never seen it in the markets, either in France or Spain, even where other sorts were exhibited for sale in abundance. Our specimens came from Dorking, in Surrey, and one fine fellow, we kept alive for a long time; but one day in spring, thinking a feast would do him good after his winter sleep, we left him in a lettuce bed by himself, but he took a mean advantage of his parole, and when we went to fetch him in, he had vanished and left no sign. 2. The -Common Snail (H. aspersa). He requires no introduction, being known only too well. It is not, however, so well known what a curious way he has of showing his regard to his female acquaintances. He stabs them with one or more love-darts, as they are called, a crystalline spike about half an inch in length; and if you happen to discover a pair of these Snails amorously inclined, ten to one but what you will find these "affection's offerings" deeply embedded in the skin of the fair one. A tablet of these creatures, from the smallest newly-born shell to the fully grown, accompanied by a few of these love-darts, is by no means unworthy a place in any museum. 
I 24 THE STORY OF OUR MUSEUM.

3. The Wood-snail (H. nemoralis); and 4. The Garden-snail ( $H$. hortensis). Authorities differ as to whether these are distinct species, or merely varieties of the same. The former has the rim of the mouth of the shell dark, the latter white. They exhibit an endless variety of colour and markings, and form by far the showiest tablets in a collection of land-shells. M. Albin Gras, a French conchologist, has enumerated no less than one hundred and ninety-eight varieties of the Wood-snail; and M. Moquin Tandon fortysix of the Garden-snail. How the dispute as to the identity or otherwise of the two will be settled one cannot say, but considering that they are connected by an intermediate variety (H. hybrida), it looks as if Linnæus was right in uniting them. Mr. Gwyn Jeffreys quotes a passage, showing that in Southey's days the schoolboys used to back the "black mouths" against the "white mouths" in trials of strength, just as nowadays they do walnut-shells. 5. The Kentish Snail (H. Cantiana) is a very pretty shell, of the most delicate pink brown. It must be collected rather late in the autumn, as the mouth will not be fully formed till then. 6. The Zoned Snail (H. virgata) is an upland species, and is often to be met with in incredible numbers on heaths and downs, more particularly near the sea; in fact, it is said that Southdown 
and Dartmoor mutton owes its sweetness to the quantity of these little snails which the sheep unwittingly eat with the grass. 7. Its big brother, the Heath-snail (H. ericetorum), is easily distinguished by its greater size and large umbilicus. It is common enough on the Cotswolds. 8. The Pygmy Snail (H. pygmaa). This is not a particularly happy name for the Snail in question, the Pygmies, that valiant African people who fought with the Cranes, being a cubit $(\pi v \gamma \mu \eta \dot{\eta})$ in height, whereas these Snails are not much bigger than a pin's head. They stick to tufts of dry grass among rocks or on walls, and the way to find them is to pull up some likely tufts and shake them over a newspaper, when the snails, if there are any in, will tumble out. A tablet of the size we used will give room for four or five rows, and they look very well so arranged, though visitors often amused us by expressing their wonder how we could ever find such mites. One of the main uses of collecting Snails is to teach one to use one's eyes, and we certainly never saw anything wonderful in the feat. 9. The Pretty or White Snail is just as minute, and yet books on Snails not only describe the striated horny jaw of this little beauty, but even tell us that it has 1860 teeth, which shows that somebody must have counted them. Nay, more, a French naturalist has discovered that the 
Pygmy Snail has got an exceedingly bad temper of its own, and displays considerable irritation when interfered with. Fancy a pin's head putting itself into a passion! IO. The Rocksnail (H. lapicida) is unlike any other British species, and has a very foreign appearance. It is common enough, and only last year (I880) I gathered a handful of them and the large Bulimus on the beech trees of Selborne Hanger. I I. The last I need mention is the Cheese-snail (H. obvoluta), still more foreign-looking, owing to the indented form of the mouth of its shell. It is scarce, in fact only to be found on the north side of the chalk escarpment of the South Downs from Buriton in Hampshire to Graffham in Sussex. We had only two specimens, and they were "dead" ones, given us by a friend in Sussex.

V. After Helix, or Snails proper, comes the genus Bulimus, a word, it is said, of African origin, of which no one seems quite to know the meaning. There are three native species, all of which we possessed. I. The Banded Twistshell (Bulimus acutus), a grey spiral shell, about half an inch in length, only to be found in the neighbourhood of the sea. At St. Jean de Luz, south of Biarritz, I have seen the samphire bushes on the shore laden with them. 2. The Mountain Twist-shell (B. montanus) - the species I found on Selborne Hanger in compary with 
the Rock-snail. It is the largest and handsomest of the trio, being nearly an inch in length and of a deep amber colour. It is very common on the beech trees about Woodchester. 3. The Dull Twist-shell ( $B$.obscurus) is a snail which always excites my astonishment, from the power it possesses of coating its shell with substances similar to what it is clinging to. The Rev. Revett Sheppard * has observed the same phenomenon. "These shells," he says, "particularly in their young state, show great sagacity and ingenuity by covering themselves with an epidermis adapted to the different situations in which they are found; and when so covered, it is almost impossible for any other than a conchological eye to detect them. If its abode be upon the trunk of a tree covered with Lichens, then is the epidermis so constructed as to cause the shell to resemble a little knot on the bark covered with such substances. If on a smooth tree, from whose bark issue small sessile buds, as is frequently the case, $\dagger$ it will pass off very well for one of them; and on a dry bank, or the lower part of the body of a tree splashed with mud, its appearance will be that of a little misshapen pointed piece of dirt." How it manages to do this is the wonder; why it does is plain enough, viz., to escape the quick eyes of birds.

" Quoted by Mr. Giwyn Jeffreys, "British Conchology," volı ı. p. 23 E.

+ l.s.. with the Beech tree. 
VI. The Chrysalis Snails (Pupa) come next, the family containing four species. They are all very small, and it requires a practised eye to detect the differences which mark one species from another. We had only two sorts-the Umbilicated (Pupa umbilicata) and the Margined ( $P$. marginata), distinguished from it by the thickened margin of the lip. They are to be looked for under stones in woods, or clinging to rocks.

VII. Smaller still are the Whorl-snails (Vertigo), possessing only two horns, or tentacles, instead of four. There are nine species, all rather scarce, especially Vertigo moulinsiana, which was discovered by Mr. Gwyn Jeffreys, in I 845 , at Ballinahinch, in Ireland, its only yet known habitat. Our example of the genus was confined to the Pygmy Whorl-shell ( $V$.pygmaa).

VIII. Then follows the Moss-shell (Balia), for we have only one native species. Its shell is reversed, i.e., twists the wrong way.

IX. The Close-snails (Clausilia) are more interesting than the last three groups. Their distinguishing feature is the possession of a singular contrivance called the clausilium, which acts as a spring-door, to keep out uninvited visitors. It can only be got at by breaking up the shell. The large Laminated Closeshell is the best species to take for this pur- 
pose. The Wrinkled (C. rugosa) is the commonest, and may be found on damp rocks and stones almost anywhere. The Folded (C. biplicata) is very handsome, of a lovely cream colour, but very rare in England. The specimens in our museum I found on the enormous cyclopæan walls of Tarragona. The Laminated (C. laminata) is not so common but that its discovery is an event. It is an arboreal species, and I never found it in such abundance as on the beech trees of Selborne Hanger, in company with those two other beauties, the Rock-snail and the Mountain Bulimus. There is one other species, the very rare Clausilia Rolphii, which we never found ourselves, but a friend in Sussex, who one day captured above fifty, kindly shared his spoils with us.

X. The Varnished Shell (Cochlicopa or Zua lubrica) is that little glossy shell one finds under large stones in damp situations. Mr. Tate says it is a favourite food of the Starling. If so, I am afraid the Starling very seldom has the pleasure of tasting his favourite food, as it generally lies under stones much too large for him to turn, even if the thought of performing such a feat ever came into his head.

XI. The Agate-shells (Achatina), which in Africa grow to the length of eight inches, and lay eggs more than an inch long, are represented 
in Britain by but a single minute species, the Needle Agate-shell (Achatina acicula), which I never found, except on one occasion. There was lately discovered near Chichester what appears to have been an early British buryingground. Many skeletons were found, accompanied by pottery of the rudest description and short iron knives. One example of what is called "ring-money" was also turned up. The skulls are of the most debased type. The bones, which lay about three feet below the surface, were infested with Achatina acicula! It seems to prefer living under the earth rather than on it. It is related that once a gentleman in Hertfordshire turned up a considerable number while digging potatoes. At first they were mistaken for little white maggots.

Of the operculated land-shells there are only two genera indigenous to Britain, the first of

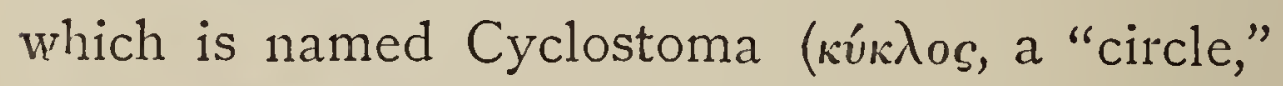

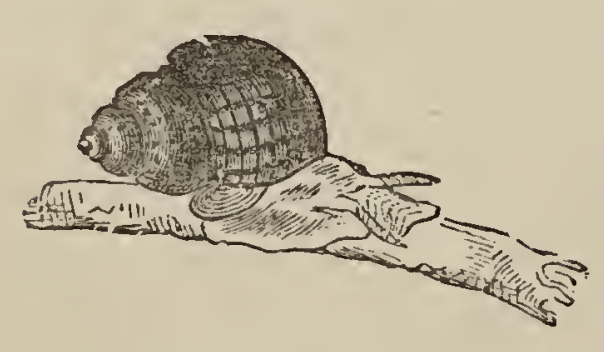

Cyclostoma elegans. and бrópa, "a mouth"). The most remarkable family feature is the shelly operculum with which it shuts out intruders. The Elegant Cyclostoma (Cyclostoma elegans) is the prettiest of all our British land-snails, and its sculptured shell is often still further adorned with pink, 
yellow, or purple streaks. It is only found in chalk or limestone districts, and is partial to sea air; at the same time it will thrive in confinement anywhere, and of all the native shells it is the best to keep as a pet. I kept some once in London, giving them pieces of limestone to crawl over, and lettuce to eat. As they walk up the sides of their glass prison, you can notice a phenomenon which no other English snail exhibits, and if you make a Common Snail (H. aspersa) walk up the glass by their side, you will see it all the better by comparison. The Snail moves along by muscular undulations extending across the whole of its stomach-foot, whereas in the Cyclostoma you will see that its foot is dual, acting in separate and independent halves, and that it walks with an alternate action of the two sides. Our friend the Cyclostoma is sadly troubled with shyness, and if you disturb bim while eating or walking, it takes him a long time either to forgive or forget the intcruption. A tablet of this shell in all stages of growth is a very pretty and interesting object: some of the specimens, however, ought to be cut in half, so as to show the spiral arrangement inside.

The other genus, Acme, is so rare that I have never seen a living specimen.

This sketch of our British land-shells as illus- 
trated in our museum will, I hope, be sufficient to indicate what pleasure and information may be gathered from collecting and studying land-shells. It adds yet another charm to the country ramble, and teaches one to feel what a world of interest may be lying unsuspected or even slighted at one's very feet. It gives also an additional interest to the visiting new districts and countries. Once, as I was journeying through that great and terrible wilderness. which lies north of the Atlas Mountains, the only signs of life which the burnt-up and barren region afforded were myriads of White Snails of species altogether strange to me, which clustered so thickly upon the parched thorn bushes as to look at a distance like masses of snow-white blossom. I made a selection of them as I travelled, and showing them on my return to England to Dr. Baird, the Keeper of the Conchological Department of the British Museum, had the satisfaction of hearing from him that one of them* was altogether new. So we see that even the play-science of boys, while it adds quickness to their observation and delicacy to their touch, may even ultimately add to the scientific knowledge of the age.

* Courteously named by Dr. Baird, Helix Housmani. 
List of Land Molluscs in our Museum.

Ear-shaped Testacella ...... Common Amber Snais ...... Elegant Amber Snail.......... Green Vitrina

Cellar Snailet

Garlic Snailet ..................

Dull Snailet.

Apple Snail

Common Snail

Wood SnaiI .....................

Garden Snail ..................

Shrub Snail...................

Kentish Snail .................

Rufous Snail ................

Bristly Snail .................

Zoned Snail......................

Wrinkled Snail ...............

Heath Snail .................

Radiaied Snail ..............

Wall Snail ....................

Pygmy Snail .................

Pretty or White Snail ......

Rock Snail ....................

Cheese Snail

Banded Twist-shell

Mountain Twist-shell.........

Dull Twist-shell ..............

Umbilicated Chrysalis-shell

Margined Chrysalis-shell ...

Pygmy Whorl-shell .........

Fragile Moss-shell ............

Folded Clausilia ...............

Laminated Clausilia ..........

Wrinkled Clausilia............

Rolph's Clausilia ............

Varnished Sheli

Elegant Cyclostoma
Testacella naliotidea

Succinea putris

- elegans

Vitrina pellucida

Zonites cellarius

- alliarius nitidulus

Helix pomatia

- aspersa

— nemoralis

— var. hortensis (?)

— arbustorum

- Cantiana

— rufescens

—_ hispida

— virgata

— caperata

- ericetorum

— rotundata

— rupestris

— pygmæa

- pulchella

_ lapicida

- obvoluta

Bulimus acutus

- montanus obscurus

Pupa umbilicata

— marginata

Vertigo pygmæa

Baìia perversa

Clausilia biplicata (foreign)

- laminata

— rugosa

- Rolphii

Cochlicopa (Zue) lubrica

Cyclostoma elegans 
I34 THE STORY OF OUR MUSEUM.

Books.--Beginners cannot do better than get "British Mollusca," by Ralph Tate, F.G.S., F.A.S.L. (Hardwick); afterwards Mr. J. Gwyn Jeffreys" "British Conchology," vol. i. (Van Voorsi $)$, should by all means be procured.

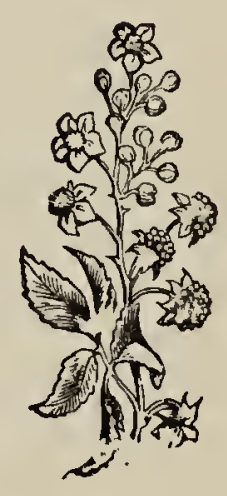




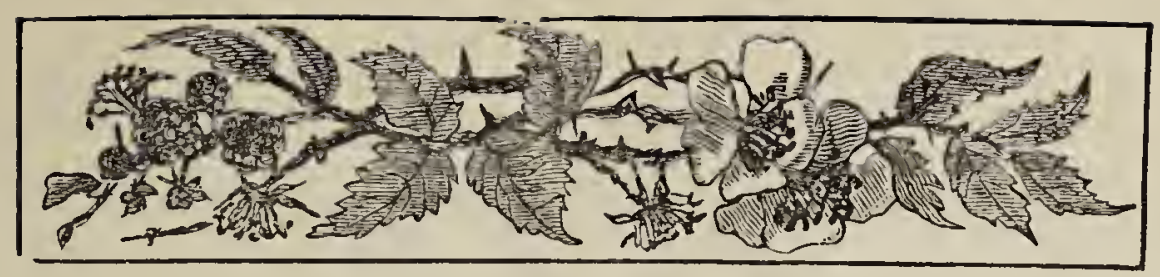

\section{CHAPTER XIII.}

THE BOTANICAL DEPARTMENT.

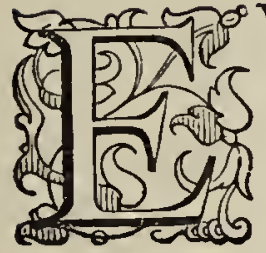

VERYBODY loves flowers, but not one in a hundred loves botany. It seems strange at first sight that, while flowers attract, their study should repel; yet so it is, and the reason is easy to be found in that, of all natural sciences, botany is the most beset with hair-splitting distinctions and technical words. For my own part, I do not see why English flowers should not be called by their pretty English names, and I am quite sure that a very good general knowledge of them may be acquired without any serious injury to the organs of pronunciation.

It was not till my brother went away to school, and I was left a good deal alone at Woodchester, that I paid much attention to 
wild flowers. Happily I had a work on the subject which made even the preliminaries of the study a pastime and a delight-a little green book with a red back, in two volumes, entitled "The Little Botanist," by Caroine A. Halsted.*

So far as the names of the parts of a flower are concerned, no one need be afraid of such obviously necessary words as calyx, corolla, stamens, pericarp, receptacle, etc., as there is nothing in them to alarm anybody. And even when we come to the Linnæan names of the classes and orders-e.g., Mon-andria, Di-andria. etc.-they are so appropriate and so musical in themselves, that they are worth while mastering. and if mastered early in life will savour-at least they have ever since boyhood savoured to menot of the lexicon, but of the sweet breath of the woods and meadows. $f$ In fact, being very much in love with flowers as a boy, I was getting on rather well with botany under the guidance of my little green book with the red back, when one unlucky day I was told that the Linnæan system which I had been following was exploded, and that the Natural was alone worthy of study.

* Published by Harris, St. Paul's Churchyard.

$\dagger$ As two-thirds of the difficulty about such words arise from not knowing their meaning and how to pronounce them, I print them with a hyphen, which will indicate their pronunciation, and often give a clue to their meaning. 
From that day I made no more progress. The new terminology bewildered me. I did not want to become a scientific botanist-both structural and physiological botany had no charms for me -all I wanted was to know the names of the flowers I met with, and, if I found any new ones, to be able to learn something about them in a book of botany. I felt ashamed not to know the names of the common flowers in a country walk-it was as bad as not knowing the names of one's friends. This feeling-the desire that is to know just as much as this, without plunging into the depths of scientific botany-is, I have since found out, shared by thousands. My advice to such-and I have talked the matter over with one of the most celebrated botanists in England-is this: begin with the Linnæan system; you can follow it up with the Natural afterwards if you like, but begin with the Linnæan. It has its disadvantages and its weak points, as you will in due time discover for yourself; but it has also the great advantage of enabling you to find out with ease and certainty the name of any British flower you may discover.

I should advise you to follow out the admirable plan of the little book I have named, which is as follows.

First make yourself thoroughly familiar with the various parts of an ordinary blossom-say a 
Primrose. Pick a Primrose, and then pull the blossom out of its cup. You have then the blossom in two parts, and all you have to do is to find out the component parts of each. The part you have pulled out is the corolla; the green cup out of which you pulled it is the calyx. Inside the corolla you will find five stamens, each consisting of two parts: the fine thread or filcment, and the anther at the top of it. The calyx, composed of sepals, or leaves, contains the ovary or seed-vessal, upon which stands the pistil, surmounted by the stigma. Once familiar with the

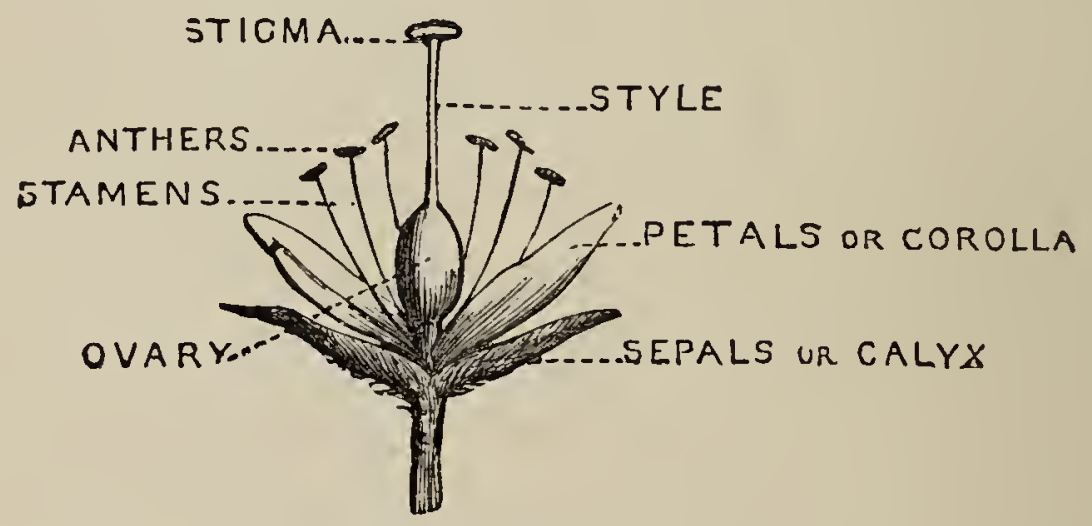

different parts of one blossom, it is easy to go on to those of others. Those of the Pea tribebutterfly flowers, as they are called-have a peculiar anatomy, and therefore require special terms for their description, but these are easily learned; and the same may be said of the grasses, and of the composite blossoms, such as the Daisy or Dandelion.

Thus in two or three hours you can master 
the component parts of an ordinary fower; and if you dry each part separately, and gum them on a card, each with its name written under, it will help you to remember all the more easily what you have learned.

Having, then, mastered the subject so far, you can go on to write out a list of the twenty-four Linnæan classes, leaving the orders for a future time. The names are long, but by carefully noting the Greek words of which they are compounded, and observing how they apply to the flowers in question, you need not be afraid of them.

What we did, having got on so far, was at once to begin to make a collection of dried flowers, aiming, in the first instance, at getting at least one flower to illustrate each class. The most difficult to get is an example of the first, as there are only three native plants belonging to it. For a long time the Mare's-tail, not uncommon in pools and ditches, was our only example, until one day we found the Jointed Glasswort on Hayling Island, at the mouth of Chichester Harbour. For the second class, flowers with two stamens, we had the pretty blue Germander Speedwell, so common in country churchyards, also the Privet, and Enchanter's Nightshade. For the third, the large Yellow Flag, a very handsome flower even when dried; and for 
the fourth, the sweet Wood-ruff. The fifth is a very large class, in fact the largest of all, as it is said to comprehend at least one-tenth of all known plants. The Primrose is as typical an example of it as any; the Brook-weed is very interesting, as being one of the few plants which are found in all latitudes, from the Arctic regions to the Tropics. The Daffodil and Bluebell are showy illustrations of the sixth class. But the seventh has only one native representative, the Chickweed Winter-green, which Linnæus used to call his "favourite little plant;" but as it is rare and confined to the North, we made the naturalized Horse-chestnut do in its place. All the Heaths belong to the eighth class, as well as the very common Willow-herb; while the ninth, like the seventh, has but one British example, the handsome Flowering-rush. The Ragged Robin is a good representative of the tenth class.

Coming next to the three classes which have the number of their stamens uncertain, they may be illustrated by the Purple Loosestrife, Wild Rose, and Celandine respectively. The fourteenth class comprises the lipped, or Labiate plants, of which the common White Dead-nettle is a good illustration, and to be found in any hedge ; while the class which follows it is equivalent to the Cruciferce, or cross-form flowers, such as the Wall-flower. 
The sixteenth and two succeeding classes are distinguished by the union of their stamens into one, two, or more parcels. The first contains the beaked plants, the receptacle being long and pointed like a bird's beak, as in the greenhouse you will see in a Pelargonium, and out of doors in the beautiful blue Crane's-bill of the meadows. The next class contains the butterfly, or Papilionaceous plants, like the Sweet-pea or Vetch; while the eighteenth contains only one genus indigenous to Britain, the St. Jolnn's-worts, possessing balsamic leaves. The nineteenth class comprises the compound flowers like the Dandelion and Daisy. The twentieth was a favourite class with us, as the calcareous soil about Woodchester abounded with orchises, which belong to it. On the hills were the Bee, in the woods the Fly, in the meadows the Early, and I dare say, had we known more about them, we should have discovered the greater number of the family. The Lady's-slipper we knew it was useless to look for, but I have since found it growing in abundance in Canada, near Quebec. The twentyfirst class, so curious from having the stamens and pistils on different parts of the same plant, like the Hazel-nut; and the twenty-second, with these parts still further separated on different plants like the Dog's-mercury and the Hop ; and the twenty-third, which accommodates flowers 
that won't go anywhere else, were all represented in our little herbarium. As for the last class, Cryptogamia, or the Ferns, they form a distinct branch of the science which we did not neglects always having an eye for ferns in our rambles.

'The above account of the Classes and their representatives makes dry reading, but it may be of use just to show how we began, and how I should recommend other lads to begin if they wish to avoid getting swamped with the technicalities of botany at starting. And after all, it is an exceedingly interesting thing to make a little collection in this way, aiming only-at least for the first year-at drying a few specimens of each class. But you must not think of making such a collection in the order of the classes; that is, do not think you must get an example of the first class before you go on to the second. For example, you can hardly look out too early in the spring for the Hazel, with its yellow catkins and crimson stigmas as your example of the Mon-œcious plants, Class XXI. Looking for the Dog's-marcury, too, illustrative of the twentysecond, or Di-œcious class, must not be delayed toc long. You will not find the one-stamened Mare's-tail in blossom till May or June, while the naked-flowering Crocus, which is as good an example as any other of Tri-andria, the third class, blossoms from September to November. 
As you zet familiar with the Linnæan system, you will be preparing for the Natural. At all events, its outlines are easily acquired, such as the

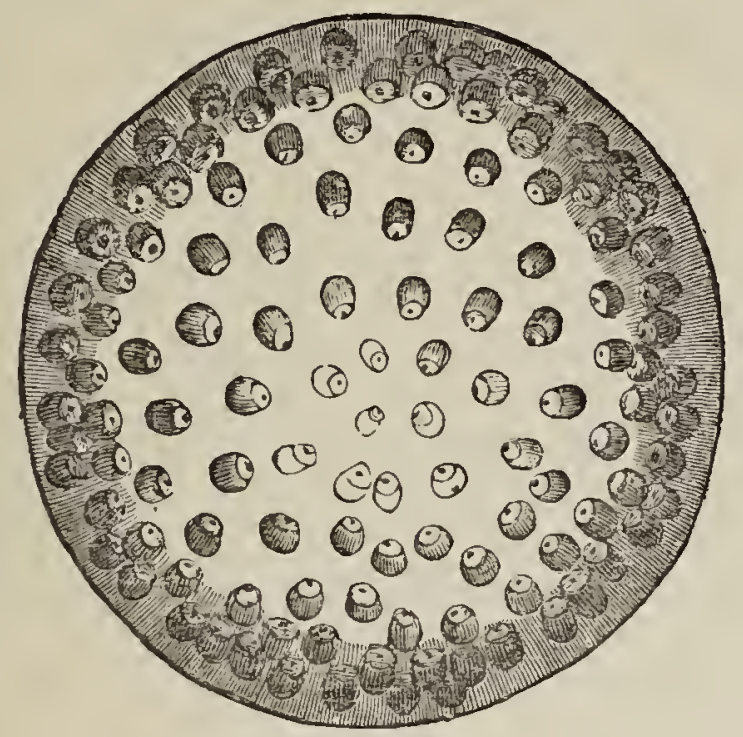

Section of Stem of Exogen.

two great divisions of Exogens and Endogens, readily remembered by the network structure of the leaves of the former, and the parallel veins

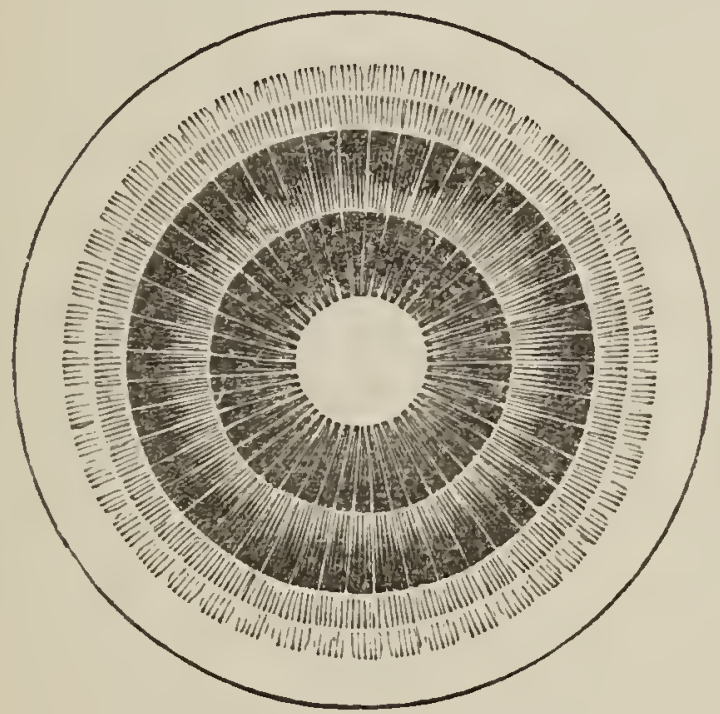

Section of Stem of Endogen.

of those of the latter. Hold up an oak leaf and a blade of grass to the light, and you will see the 


\section{I44 THF BOTANICA.L DEPARTMENT.}

distinction in an instant. The four orders of the Exogens are not very difficult to understand: Thalami-flore, i.e., having the stamens inserted upon the thalamus or receptacle; Calyci-florce,

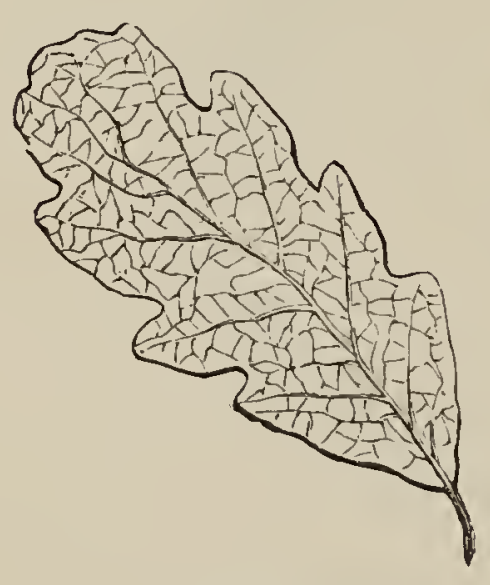

Leaf of Exoger.

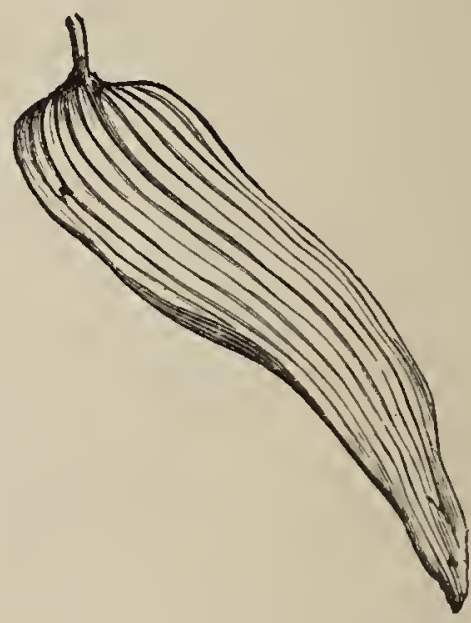

Leaf of Endogen.

with the stamens upon the calyx or ovary; Corolli-flore, with the petals united, and the stamens either inserted beneath the pistil or joined to the petals; and the Mono-chlamydece, which have only one floral envelope, or have neither calyx nor corolla.

You will see in time that some of the classes of the Linnæan arrangement are identical, or nearly so, with certain genera of the Natural. Thus, Order XIV., Di-dynamia, includes the Labiates, or lipped plants, and also a great part of the Fig-wort (Scrophulariaceæ) order; XV., Tetra-dynamia, coincides with the Cruciferæ, or cross-shaped flowers; and XIX., Syn-genesia, with the Compositæ. But again, I repeat, if you 
merely want to be able to find out the names of the wild flowers of your walks, and do not want to be disheartened with technical terms, stick to the Linnæan system, and at first avoid all books on structural or physiological botany. You can go on to these, of course, when you are well grounded in the first principles of the science; but if you take them up too soon, they will only discourage and overwhelm you. Avoid all technical terms which are not absolutely necessary; but the indispensable ones, such as the names of the classes, orders, parts of a plant, and the like, make a point of understanding thorouglily. I may also add, use the index of whatever book on botany you may have; look out Bell-flower, for example, and work back from the name to the characteristic marks of the plant ; then use both Linnæan and Natural systems as given in Johns' "Flowers of the Field," Babbington's "Botany," or any other good book.

The geographical distribution of plants is a very interesting subject, and helps to make you fond of geography and books of travels, and you will find the chapter on it in the "Gallery of Nature" one of the most delightful in the book; and it throws a tenfold charm over the beauties of a hothouse to look upon them as representatives of the various botanical regions from which they have been brought. I was quite 
surprised, when rambling for the first time about the Rock of Gibraltar, to observe the prevalence of the Labiates over all other orders; but on referring afterwards to the "Gallery of Nature," I saw that it ought not to have surprised me, as it is stated there that the Mediterranean flora is the region of the Labiate and Caryophilla. That region, the book goes on to say, is divided into five provinces, that of the Cistuses or Rock-roses, which make the hills about Tangier gay, even in winter; and the Labiate, which are said to abound still more towards the eastern end of the Mediterranean. The writer then goes on to speak of "the Atlantic province, including the north of Africa, of which Professor Schouw has ascertained no distinctive character." As I have travelled in those regions more, perhaps, than many Europeans, I would suggest that it be called "the province of the Argan." This is the tree from the berries of which the argan oil is expressed, and is exclusively confined to this region, never being found north of the Straits of Gibraltar or south of the Soudan.

The drying of flowers is a simple matter, yet it requires care and nicety of handling. You must avoid carrying home in your hand the specimens you intend to press, or the heat of your hand will make them droop before their time, and with some sorts, such as the Speedwells or Crane's- 
bills, cause the blossoms to drop off. If you happen to find anything interesting when unprovided with a box of any kind - the usual botanical tin box is the best-wrap plenty of large leaves or fern fronds round the stem, and carry it by the ends of the leaves or fronds thus used. To dry flowers, lay them carefully between sheets of blotting-paper, which must then be squeezed as tight as possible. This may be done in an ordinary clothes-press, or between two smooth pieces of board, upon the upper of which you can pile up books or bricks. Look at your specimens the next day, and put any petal or leaf straight that may have got doubled up, but on no account take the specimens out of the blotting-paper till they are perfectly dry. Then get what stationers call "soiled outsides," foolscap size, and place each plant, or group of the same plant it it is small, on the inside of a sheet, fixing it by little strips of gummed paper. Then write the English and botanical name of the plant on the outside, together with the locality and date, putting the number of the class and order in large Roman figures in the right-hand corner at the top. The specimens, thus arranged, can be kept in a cover or box, and the oftener you look through them, the firmer will the names of the flowers be imprinted on your memory. 


\section{List of some of our Dried Flowers.*}

Class I.-Mon-andria: I stamen.

Jointed Glasswort ......... $\mid$ Muddy sea-shores

Mare's-tail ................

Class II.-Di-andria: 2 stamens.

Privet

Speedivell (various) ......

Enchanter's Nightshade... $\mid$ Woods

Class III.-Tri-andria: 3 stamens.

Crocus

Yellow Flag

Meadows

Grasses $\dagger$ (various).........

CLASS IV.-Tetr-andria: 4 stamens.

Knautia

Corn-fields

Bed-straw (various)

Wood-ruff

Waste places

Woods

Class V.-Pent-andria: 5 stamens.

Viper's Bugloss Fields

Borage

Forget-me-not.

Waste places

Primrose

Cowslip

Banks of streams

Hedge-banks, etc.

Meadows

Henbane

Waste places

Periwinkle

Honeysuckle

Violet

Thrift

Banks

Hedges

Hedge-banks

Mud-banks in harbours

Sun-dew

Marshes

Class VI. - Hex-andria: 6 stamens.

Snowdrop

Daffodil

Lily of the valley

Star of Bethlehem

Bluebell
Woods

Meadows

Woods at Woodchester and Shrawley

Fishbourne, Sussex

Coppices

* Only a few of the more representative ones are given.

$\dagger$ It is best to treat the grasses like the ferns or mosses, and make a distinct collection and study of them. 
Class VII.-Hept-andria: 7 stamens.

Horse-chestrut .......... | Shrubberies (native of Asia)

Class VIII.-Oct-andria: 8 stamens.

Heaths (various)............ Hills

Willow-herb .............. Sides of streams

Spurge-laure1 .............. Beech woods

Persicaria (various)........

Class IX.-Enne-andria: 9 stamens.

Flowering-rush .......... | Canas

Class X.-Dec-andria: ro stamens.

Saxifrage (various)......... $\mid$ Rocky places

Bladder Campion ......... Road-sides

Stonecrop ................. Walls

Ragged Robin.............. Pastures

Class XI.-Dodec-andria: I2 to I 9 stamens.

Purple Loosestrife

Agrimony

Marshes

Wild Mignonette .........

Class XII. - Icos andria: 20 or more stamens on the calyx. (Natural order, Rosacece in part.)

Hawthorn

Cotoneaster.

Meadow-swect

Hedges

Rocks near Llancudno

Road-sides

Rose (various).............. Hedges

Bramble .................. Ditto

Strawberry ................ Woods

CLASS XIII - Poly-andria: many stamens on the receptacle.

(Natural order, Ranzmculacee and its allied orders.)

Poppy

Horned Poppy

Celandine

Green Hellebore.

'Traveller's Joy

Wood Anemone

Pheasant's-eye.

Marsh Marigold
Corn-fields

Sea-shore

Pastures and hedge-banks

Woods

Hedges

Woods

Corn-fields

Marshes 
CLASS XIV.-Di-dynamia: 4 stamens-2 long, 2 short.

(Natural order, Labiate and Scrophulariacce in part.)

Mint (various) .............
Penny-royal...............
Thyme ...................
Wood Sage ...............
Bugle ....................
Weasel-snout, or Arch.
angel...................
White Dead-nettle .......
Red Dead-nettle.........
Woundwort ...............
Yellow Rattle............
Toad-flax..................
Figwort ..................
Foxglove ..................
Sides of ponds

Ditto

Hills

Woods

Moist places

Hedges

Ditto

Ditto

Ditto

Hay-fields

Hedges

By streams

Coppices

C1.ASS XV.-Tetra-dynamia: 6 stamens-4 iong, e short. (Natural order, Cruciferce.)

\begin{tabular}{l|l} 
Shepherd's-purse........... & Gardens \\
Scurvy-grass $\ldots . . . . . . . . . .$. & Sea-coasts \\
Water-cress ................ & Streams and ponds \\
London Rocket $\ldots . . . . . .$. & Waste places \\
Charlock .................. & Corn-fields
\end{tabular}

Class XVI. - Mon-adelphia : filaments combined in one set.

Meadow Crane's-bill

Herb Robert

Common Mallow

\section{Meadows}

Waste ground

Ditto

ClAss XVII. - Di-adelphia : fiaments combined in troo sets.

Fumitory Milkwort

Furze, Whin, o, Gorse...

Broom

Rest-harrow

Vetch

\section{Corn-fields}

Hills and paistures

Hills

Heđges

Waste places

Fields

* After the Great Fire of London, in 1666, this plant sprang up everywhere among the ruins. 
Class XVIII.-Poly-adelphia: filaments combined in more than troo sets.

(Natural order, Hypericacce.)

St. John's-wort (various) | Hedges and waste places

CLASS XIX.-Syn-genesia: anthers united into a tube. Flower compound.

(Natural order, Composite.)

Hawk-bit (two species)...

Mouse-ear Hawkweed ...

Dandelion

Succory

Thistle (various species)..

Tansy .......................

Cudweed

Colt's-foot ................

Feverfew

Blue-bottle

CLASS XX.-Gyn-andria: stamens situated upon the style, above the germen.

(Naturai order, Orchidacea.)

Early Orchis

Marsh Orchis

Spottec Orchis

Fragrant Orchis

Frog Orchis

Bee Orchis

Fly Orchis

Lady's Tresses....

Tway-blade

Bird's-nest Orchis*

Helleborine (various).... .
Heaths

Dry places

Fields

Road-sides

Ditto

Ditto

Hills

Waste places

Ditto

Corn-fields 
Class XXII.--Di-ccia: stamens and pistils on different plants.

Willow (various) By water

Hop.

Biack Bryony .

Mercury

Frog-bit Hedges

Ditto

Under hedges

Ponds

CLASS XXIII.-Poly-gamia: stamens and pistils separate or united, on the same or on different plants, and having two different kinds of perianth.*

Spreading Orache ........ | Waste ground

Class XXII._Crypto-gamia: stamens and pistils not visible. The Ferns.

As I remarked before, we treated our Ferns as a distinct branch of collecting, and also the Mosses, which are most interesting, besides possessing the additional advantage of having to be sought in winter, when other plants are asleep. The Fungi are also well worth studying, and (with the help of Dr. M. C. Cooke's "British Fungi" $\dagger$ ) give you a new interest in the autumn woods. In fact, Ferns, Mosses, Fungi, and land-shells can all be hunted for together. Yet some people call the country dull! The dulness certainly is not on the part of the country; but to enjoy the country you must take an intelligent interest in the things of the country, and it is just to help you to see how interesting and how various they are, that this book has been written.

* When the calyx is coloured, and consists of only one piece, it is called a perianth.

+ Published by Hardwick, price 6 s. 
If the volumes in the Little Library series, entitled "The Little Botanist," are out of print, let the student by all means get "Flowers of the Field," by Rev. C. A. Johns (S.P.C.K.). It is carefully illustrated, and supplied with an introduction, together with the Linnæan system formed into a key to the Natural orders. Let him also obtain Bland's "Elementary Botany," Parts I. and II. (sixpence each), which are full of good woodcuts. As a further book of reference, he may consult Sowerby's "British Wild Flowers" (Van Voorst), or Miss Anne Pratt's "Wild Flowers" (S.P.C.K.), where he will find coloured illustrations of all our native flowers. Sowerby's "British Grasses" has coloured plates of every species : though expensive (one guinea) it is the best work to get on the subject.

It is not so easy to recommend books on Ferns, Mosses, and Fungi. Moore's shilling book on Ferns (Routledge), and Dr. Cooke's various works on Fungi, especially the Handbook, in two volumes, are all that can be desired. A good inexpensive book on Mosses is still a desideratum for a companion to the study of the vegetable kingdom in all its formis: there is nothing better than that dear old Loudon's “Encyclopædia of Plants," which may easily be bought second-hand. 


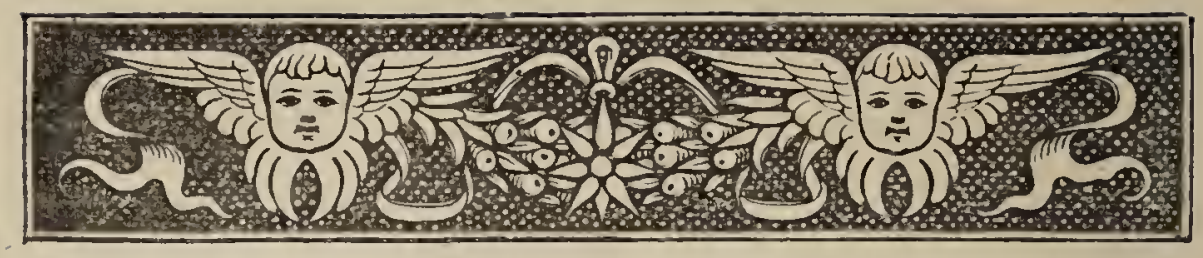

\section{CHAPTER XIV.}

FOSSILS.

gy HERE were two circumstances that led us very early in life to take a special interest in fossils: one was that Woodchester, from its peculiar geological situation, abounded with them; the other that a former Rector of the parish had been a geologist, and it had so happened that when the rectory changed hands at his death his specimens were left behind. One room in the house was set apart for this collection, and there was also a "fossil-house" in the garden, where the old gentleman cleaned and sorted his treasures before arranging them in his museum.

So between the "fossil-room" in the rectory and the "fossil-house" in the garden-which by the way was our school-room-and the fossil harvest out of doors, we were surrounded 
by the very atmosphere of fossils from our youth. What wonder, then, that the germs of fossil-fever entered into our souls, and infected us past any cure! Not that we knew much about geology at that time, but it was by loving fossils that we were preparing for geology, just as by loving flowers we were preparing for botany. In both cases the pictures of the science attracted us before the reading. All we could learn about the Terebratulas and Belemnites with which we came home laden from the quarries, was that they were the shells of fish which had formerly been alive, and that they had got washed into the ground at the Deluge! But we were quite satisfied with this explanation, and went on collecting as many sorts as we could find, and arranging them according to size in our museum. But when the "Gallery of Nature" came out, a new light burst upon us, and we saw, for the first time, in our fossils the remains of creatures which had been inhabitants of the earth in infinitely remote periods of its history. We found that the animals now existing had been preceded by an earlier and altogether different creation, and that by one still earlier and still more unlike the present; while that, ancient and strange as it was, had taken the place of an infinitely more ancient and more strange assemblage of creatures. It showed us that 
the Primary, Secondary, and Tertiary formations represented three vast ages which preceded the present, during each of which the living things upon the earth had undergone an entire change. No wonder such a revelation as this fascinated us ; and when we found that "fossils" was only another name for the shells or other remains of animals which had inhabited the world in those far-off ages, and that they had swum in the waters or lived on the ground in periods so remote that the earliest date in history seemed as yesterday in comparison, all our other collections were forsaken for a time, in our enthusiasm for the new world of wonders which had suddenly burst upon us.

At first, our only fossils were those of the Oolites of our own neighbourhood, but by exchanges, and by hunting in every new district we happened to visit, our range became largely extended, until it embraced specimens of each of the three great geological divisions. A lengthened stay in South Staffordshire gave me an intimate acquaintance, both with the Coal measures and with the Upper Silurian fossils of Dudley, and added a fine series of Trilobites to the collection.

Pernaps, as beginners, we could not have done better than to try, as we did, to obtain a few good representative fossils, not only of the Primary (as it was then called). Secondary, and 
Tertiary divisions, but of the more important subdivisions which each contains: it helped us to acquire a general knowledge of the subject. Afterwards we made this plan subservient to another system of arrangement, to be explained by-and-by.

It was a proud day for us when, through the kindness of the late Professor Jukes, we deposited in our mustum some specimens of the most ancient European fossil yet known-Oldhamia antiqua, from Bray Head, in Ireland; but prouder far when we received from Dr. Sterry Hunt, in Canada, two pieces of Laurentian limestone containing Eozoön, the oldest known fossil in the world. It was like gazing at the fount of life to hold in one's hand the very first sign of life upon the globe which has ever been discovered! At a later time we made a pilgrimage to St. David's, to search for the gigantic Paradoxides and the earliest fossil molluscs in the Menævian rocks. A day at Builth with the Field Club not only gave us some idea of the appearance of the Llandeilo formation, but enabled us to add to our stock specimens of the particular species of Trilobites for which they are celebrated. These Trilobites, which form so distinguishing a feature in the Palæozoic system, were creatures possessing a hard shelly back like a Crab's, divided lengthwise into three lobes -nence the name-more or less distinct ac- 
cording to the species, between two and three hundred of which have already been discovered in Britain.* The under side seems to have been quite soft, for in no instance has it been preserved. These creatures, ranging in size from that of the tiniest to the largest $\mathrm{Crab}$, and exhibiting an astonishing variety of shape, swarmed at the bottom of the primeval ocean as thick as Shrimps at Pegwell Bay; and, like the Shrimps, probably acted as the scavengers of those remote ages. Some were armed with spines, to intimidate the enemy; others at the approach of danger rolled themselves up into a ball, like the Armadillo Wood-louse. In one genus (Encrimurus) the eyes were raised above the head on footstalks; in another (Illcenus) they are scarcely perceptible; while in a third (Asaphus) they exhibit a beautiful faceted pattern like that of the Dragon-fly. So perfectly have these eyes in some instances been preserved, that in one of our specimens each facet can be distinctly discerned with the aid of an ordinary magnifying glass, showing in its dark centre the branch of the optic nerve! To collect these fossils, some as perfect as the day they died, was indeed to recall the past-not the past of time, but, if one may use the expression, the very past of eternity itself!

* See fig. p. 163. 
But these crustaceans were not the only tenants of the primeval seas, any more than are the Shrimps and Crabs the only inhabitants of our modern waters. There were shells also, and shells of such an old-world type that, with the exception of the few families which have survived all geological changes, and continue to the present day, they have long been erased from the roll of life, and been supplanted by others of different pattern, which in their turn have passed also to make room for a third series, after which those which now people our seabottoms began to appear. So strange and startling was it to be brought thus into contact with the inhabitants of what may almost be regarded as another world, that, had we suddenly been transported to Mars, Venus, or Jupiter, we could hardly have been more astonished with new and wcndrous forms of life.

Marvellous, too, are the pictures disclosed by a piece of coal. One cannot trace up its story without being led in imagination into vast swamps, destined to become the mining districts of the future. In the thick, steamy, heated atmosphere there rise up around us, in dense thickets, huge plants taller than our present trees-Mares'-tails, jointed Reeds, towering Palms, and Tree-ferns. Lying on the spongy ground, like immense serpents trail the stems of gigantic Club-mosses; 
while every available nook is festooned with the loveliest ferns; and all of a type and pattern which have died out of creation for ages! And

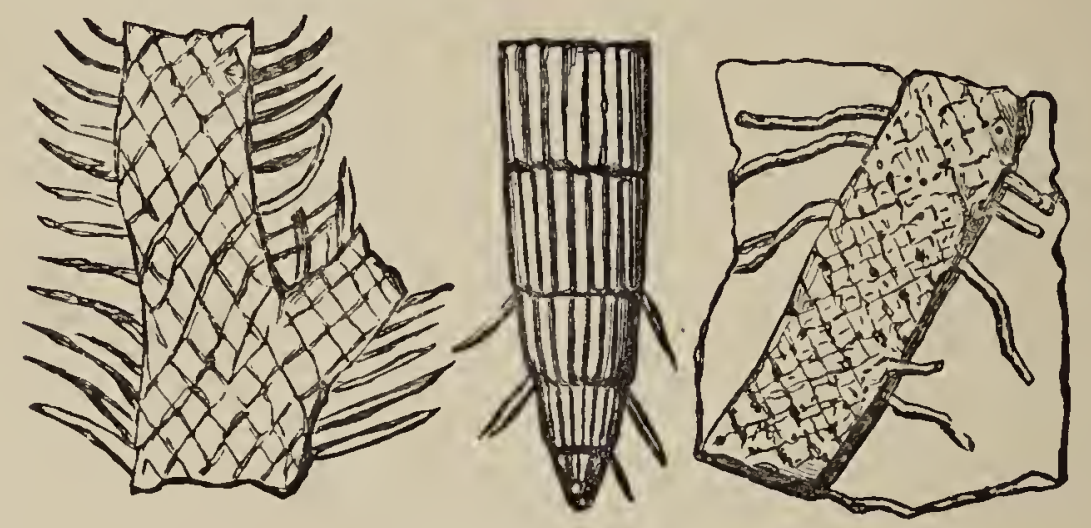

Plants from the Coal.

the wonder of it all is that this was no mere display of the Creator's power, but the evidence of His foreseeing care tor the comfort and welfare of the race which $\mathrm{He}$ would, at the last, introduce upon the earth, the completion and crown of creation.

But if the inhabitants of the Primary, or as it is now more appropriately termed the Palæozoic,

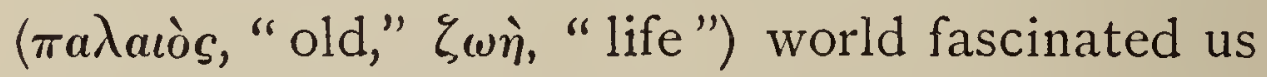
by the strangeness of their mysterious forms, those of the Secondary, or Mesozoic, period are equally marvellous in other respects. We had relations at Lyme Regis in Dorsetshire, and when visiting there, were invading the very stronghold of the old Sea-dragons-those marvellous monsters which lorded it over all other creatures during their comparatively short dynasty. As for the gigantic remains themselves, you can 
see more of them in a day at South Kensington or Jermyn Street than in a year at Lyme. Still, it is most interesting to walk under the cliffs (keeping a good look out for landslips overhead), and observe here and there a huge sea-washed bone protruding from the fallen slabs of Lias, or the traces of teeth terrible still to contemplate. What scenes have taken place on that now peaceful shore! Fancy the sea torn asunder by the onward rush of an Ichthyosaurus ( $\chi 0$ ìs, "fish," $\sigma a \tilde{v} \rho a$, " a lizard") at full paddle power, opening his terrific jaws to snap up some luckless Ganoid which he had marked for his prey; or the sight of the Plesiosaurus $(\pi \lambda \eta j \sigma \sigma \omega$, " to strike ") quietly paddling by as if at peace with bird, beast, and fish, when in an instant its long snake of a neck is darted out, and a too-

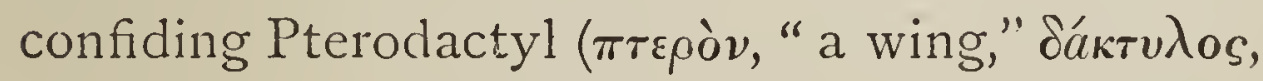
"a finger") is dragged screaming under the waves. But while the middle and the surface waters were vexed with these Sea-dragons, on the muddy bottom crawled the most lovely nacrousshells which the world had ever yet seen; lustrous Ammonites, from the diameter of a sixpence to that of the dial of a church clock, some ribbed, some striated, and some bristling with spines; while Gryphæas, with their great opercula, and many a smaller shell, bore witness to the exuberance of life in those days. 
Equally strange, too, was the tale which the Tertiary period had to tell, beginning. with a climate so tropical that even here in England Crocodiles basked, Palm trees ripened their fruits, and tropical shell-fish sparkled in the shallows; and closing in a reign of winter so terrible that mighty glaciers lay heavy on our British hills, and brought all animal life down to the very zero of existence. All this sounds wilder than a fairy tale, yet the silent fossils bear record to its truth.

With scenes such as these haunting us by day and colouring our dreams by night, no wonder we seized every opportunity of collecting the actual remains of the animals and plants which, living, had formed part in them.

To illustrate the earliest or Palæozoic period, besides the "dawn of life" fossil from the oldest sedimentary rocks (the Laurentian system of Canada), and the earliest British fossil from Ireland, we had a fine series of Trilobites, including the huge Paradoxides from St. David's, the beautiful fringed Trinucleus from the Llandeilo formation of Wales, the exquisite Trinucleus concentricus of the Caradoc, with its lace-like shield, terminating in delicate spines twice the length of the little creature's body. From the Upper Silurians, we could boast the Encrinurus punctatus, with its eyes on footstalks, its shield terminating in spines, and a strong sharp spine 
springing out of the middle of its back; the minute Cyphaspis, armed on the same principle, but with spines much longer in proportion to its size; the scarce Acidaspis, with its tail toothed like a comb; the Sphcerexochus mirus, its great smooth head looking as if it had water on the brain. Besides these, we had several species of Phacops, with faceted eyes; the solemn Illanus; and a pair of the great Homalonotus delphinocephalus, with no other means of defence than its own bulk. In addition, we had a large group of the common Calymene, some stretched out at full length, as if they had died in their sleep, and others coiled up into a ball, as though making the best defence they could to the last. But strangest of all was the Deiphon, its globular head being armed

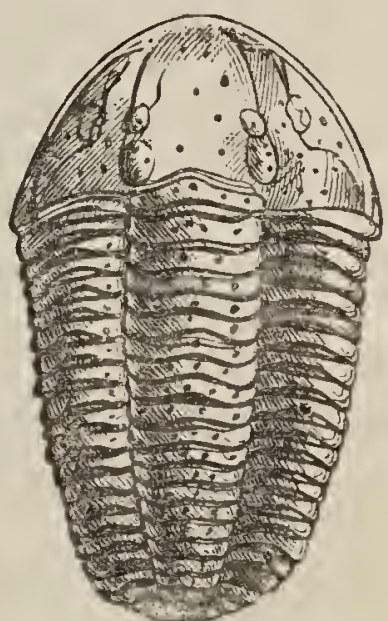

Calymene. with weapons of offence or defence. as the case may have been, like the horns of a Sitag-beetle. The body of this species must have been more than usually delicate, since only in a few instances has it been preserved. We had no Devonian species, and our series closed with one of the Carboniferous age, in which the dynasty which had ruled so long passed for ever off the stage of life. 
To illustrate the Secondary, or Mesozoic, period. we did not of course attempt to obtain the great Saurians, contenting ourselves with a few of their fragments and coprolites. Our main endeavour was to form a good series of shells, such as the Ammonites of the Lias, and the Terebratulas, Patellas, etc., of the overlying Oolites. Owing to the generosity of a friend at Brighton, we had a good series illustrative of the Chalk period, including, besides shells, many well-preserved fish and sponges.

For the Tertiaries, we had fruits and Sharks' teeth from the London clay; Miocene lignite from Bovey Tracey; and some fine shells from the Red crag of Suffolk, including the Whelk of the period (Fusus contrarius), which twisted the contrary way to the present fashion. Ascending to the post-Tertiary deposits, we had Tigers' teeth and other bones from Cefn cave; recent seashells from the raised beach of Torquay; closing the whole with a few flint instruments made by the prehistoric inhabitants of Britain. Thus, from the earliest known trace of life on the earth, to the appearance of man, we had a very fairly representative series of remains, and by collecting, arranging, and poring over these "pictures" of the science, we made some progress in geology. As for finding it dry, the very idea is absurd. It gave new life to our rambles, new 
joys to our visits in different parts of the country, while in later years it has always added fresh zest to travel or change of residence.

But, as I have already observed, this stratisraphical method of arranging our fossils in time gave place to a different one. In it, each great geological division seems isolated and separate from what preceded or followed. The past seemed severed from the present, and this did not appear to us altogether satisfactory. Its value in one sense is apparent, as the positions and relative ages of the strata, ever since the days of William Smith, the "father of geology," have been determined by their fossil contents; but what we felt was that the present is linked inseparably to the past, that the past is one with the present, and that the connecting links are fossils. Hence we concluded that it was not enough to take a fossil, a Brachiopod of the Oolite, for example, and say, "This is a Terebratula of the Oolitic period." It is simply one of a family. When did that family appear? When did it die out? or, if it has not died out, in what respects do its surviving representatives differ from the extinct? Surely if the family still exists, we shall get a clearer idea of what the former generations were by comparing them with the recent, or the light of the present is the illumination 
of the past; or, as Dr. Woodward remarks, "In whatever way geological history is written, its original investigators have only one method of proceeding-from the known to the unknown, or backwards in the course of time."* Now, as the same author tells us, that there are some families of shells still living which have existed in all the great geological systems, we felt how much more interesting would be a series of a few of these than a mere general assemblage of fossils in no way connected with each other save from living at the same periods. It was not difficult to decide which families of shells we should concentrate our attention upon, as some few are so much more conspicuous and important than others. We determined to confine ourselves to the Brachiopods-the first to appear in order of time-and of these, to devote our attention to three families only; for we felt that to study one branch of the science thoroughly was more satisfactory than to obtain a smattering of many. The three families thus selected were the Lingulas, Rhynconellas, and ' $\Gamma$ erebratulas.

The Lingula ("a spoon") is the earliest known shell. It rises, to use a geographical expression, deep down in the Cambrian rocks, the first to appear being the Lingula ferruginea of the Menævian formation of St. David's. It flourished 
through the whole of the Lower, Middle, and Upper Silurian periods; held its own during the great diminution of molluscan life which marked the advent of the Devonian age ; survived the still greater dangers of the passage into the Mesozoic, or Secondary, age; swarmed in countless profusion in the Liassic periods; suffered adversities as the age of the Chalk drew on, and though two species occur in the Greensand, in the Chalk itself it has not yet been discovered. It reappears in the Coralline crag; after which, disgusted it may be with the severity of the Glacial period, it forsook our latitudes, and betook itself to the more congenial waters of the Tropics. There it flourishes still in seven distinct species, waving its pretty green shell upon pedicles, or stalks, from an inch or two to a foot in length, and as bright and lively as Lingula. though it were the creation of yesterday, instead of being the survivor and representative of the oldest family in the world!

Only second in point of antiquity of pedigree are the Rhynconellas, so called from their turnedup beak ( $\rho \dot{v} \gamma \chi \varnothing \mathrm{s}$ ), through an aperture (foramen) in which passes the cable, or byssus, by which they moor themselves to rocks. Appearing 
first in the Lower Silurians, they became the prevailing form of shell-fish * throughout the Palæozoic age; holding a conspicuous place in the Mesozoic, where some species attained a large size ; flourishing in the days of the Chalk; after which the family is suddenly reduced in circumstances but not extinguished, for at the present day two species are still brought up by the deep-sea dredge-the one in the Arctic seas, the other off New Zealand. Dr. Woodward numbered the fossil species at two hundred and fifty, and more have been ascertained since his Manual was written. The Rhynconella psittacea, in our museum, is a black shell, and, like the Lingula, Discina, Crania, and Terebratula, which have survived a long series of geological changes, of a horny consistency.

Although not starting in the race of existence so early as the Lingulas and Rhynconellas, the Terebratulas are a more showy family, dating from the Devonian age, attaining a vast variety of size and form, very possibly of colouring also, during the whole of the Secondary period; attaining in the Oolites an extraordinary beauty of pattern; while the Terebratula grandis of the Crag is as long though not so deep as a Hen's cgg. Twc or three species still exist, one of

* Although I use this popular term, I am perfectly aware that no mollusc ought properly to be called a fish. 
FOSSILS.

which, the Terebratula caput-serpentis, was kindly given us by Dr. Woodward himself.

Of the Cranias and Discinas, both extending from the Lower Silurian ages to the present, we had a few specimens, but their flat, scaly shells are not conspicuous, while in numerical force they are very inferior to the three extensive families I have been speaking of.

Our aim, then, became latterly solely to collect these three--the Lingulas, Rhynconellas, and Terebratulas - and by exchanges, and now and then a purchase, we were able to form an interesting series. The recent species we had of course to buy, and, placing them at the head of each series, traced the family back in order of time as far as possible. Thus the recent shells gained a tenfold interest by being ex. hibited as living representatives of families which dated so far back in time; and from a study of these present forms we were enablea to form a better conception of the past.

Of course in a large museum every family of shells might be thus displayed, thus abolishing the ordinary divorce between the past and present; and enabling us to read, on a large and complete scale, the present with the past, and to judge of the extinct by the recent. 
Recent and Fossil Brachiopoda in our Museun.

1. - Terebratula.

Terebratula caput-serpentis

- australis ..............

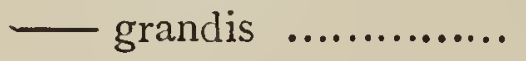

- sella .................

_ oblonga ..............

- lachrymosa............

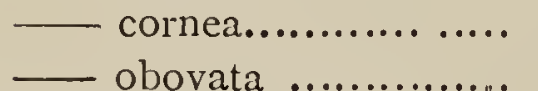

- digona..................

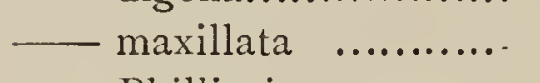

— Phillipsia ...........

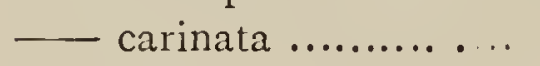

- fimbria ...............

- impressa ..............

- plicata................

- - perovalis..............

— quadrifida ........

- cornuta ..............

- — Edwardsil ...........

— virgoides.............

- hastata ...........
British Seas

Southern Ocean

Coralline and Red Crag

Lower Greensand

Ditto

Ditto

Upper Chalk

Cornbrash

Bradford Clay

Great Oolite

Inferior Oolite

Ditto

Ditto

Ditto

Ditto

Ditto

Middle Lias

Ditto

Ditto

Carboniferous Limestone

Devonian

\section{2.-Khynconella.}

\begin{tabular}{|c|c|}
\hline 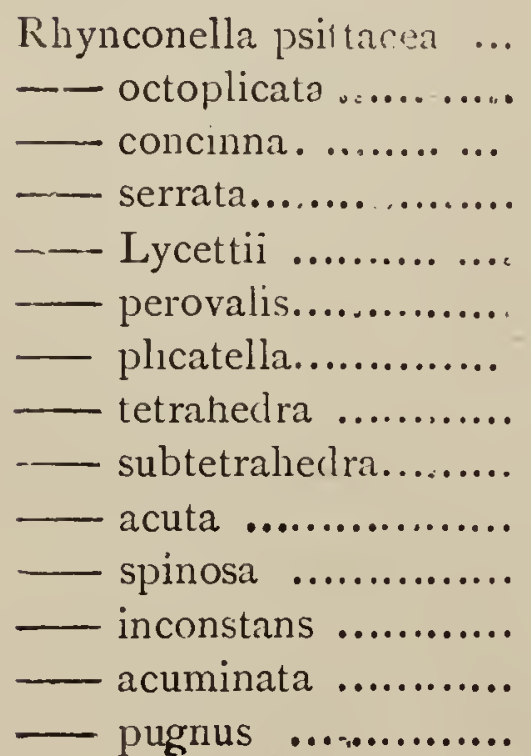 & $\begin{array}{l}\text { Greenland } \\
\text { Upper Chalk } \\
\text { Great Oolite } \\
\text { Inferior Oolite } \\
\text { Ditto } \\
\text { Ditto } \\
\text { Ditto } \\
\text { Middle Lias } \\
\text { Ditto } \\
\text { Ditto } \\
\text { Ditto } \\
\text { Lower Lias } \\
\text { Carboniferous Limestone } \\
\text { Ditto }\end{array}$ \\
\hline
\end{tabular}




\begin{tabular}{|c|c|}
\hline & \\
\hline Khynconella latecosta ... & Middle Devonian \\
\hline - nucula $\quad . . . . . . . . . . . . . .$. & Upper Ludlow \\
\hline — Wilsoni ............... & Aymestry Limestone \\
\hline - borealis $\ldots . . . . . . . . .$. & Wenlock Limestone \\
\hline — Stricklandi............ & Ditto \\
\hline - Lewisii ............. & Ditto \\
\hline - lacunosa ................ & Ditto \\
\hline - - deflexa $\quad . . . . . . . . . . .$. & Ditto \\
\hline — cuneata ......... & Ditto \\
\hline - Salteri.................. & Ditto \\
\hline — Buchii.................. & Ditto \\
\hline $\begin{array}{l}\text { — Barrandii ....... } \\
\end{array}$ & Woolhope Limestone \\
\hline
\end{tabular}

3.-Discina.

\begin{tabular}{r|l} 
Discina lamellosa ........ & $\begin{array}{l}\text { Recent seas } \\
\text { Upper Lias sands } \\
\text { reflexa................. }\end{array}$ \\
\hline nitida ............... & Coal measures \\
\hline rugosa ............... & Wpper Ludlow \\
Wenlock Shale \\
rugata ................
\end{tabular}

\section{4.-Lingula.}

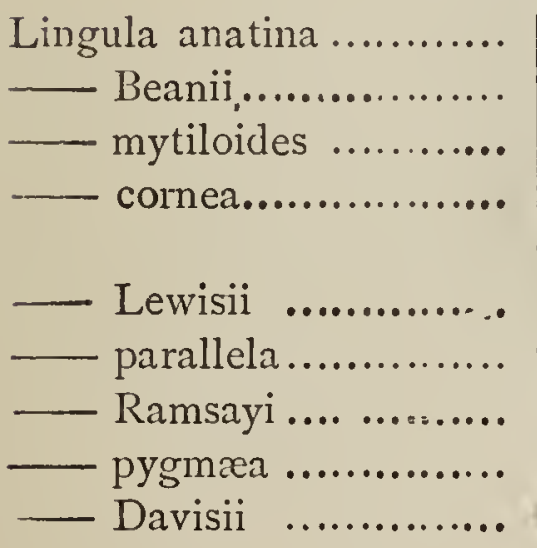

East Indian seas

Upper Lias sands

Coal measures

Lower Devonian and Upper Ludlow

Aymestry Limestone

Llandovery Sandstone

Llandeilo

Upper Lingula Flags

Lingula Flags

Besides several species in each family which we had difficulty in getting named. One species from the Holly-bush sandstone of Malverrs still remains undescribed. 
Books.-Professor Page's "Handbook of Geo$\operatorname{logy}$ " is the best for beginners. The Rev. T. G. Bonny's "Manual of Geology" (S.P.C.K.), though more elementary, is very good, and only costs one shilling. Then get Lyell's "Elements of Creology" for a more extended view of the whole subject. Most students will naturally turn their attention more particularly to the formation of their own neighbourhood, which will render works on particular systems or formations necessary, such as Murchison's "Siluria."

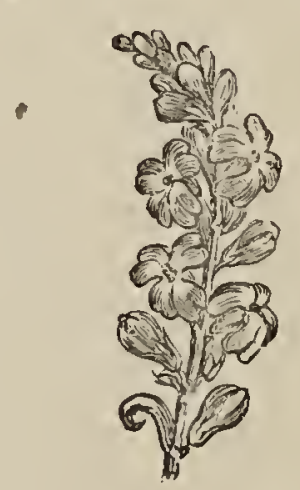




\section{CHAPTER XV.}

MINERALS.

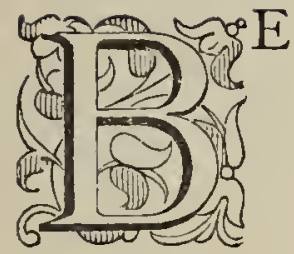

EFORE the "Gallery of Nature" had thrown such a wonderful light upon our fossils, we used to regard our minerals with no small pride and satisfaction. It is true we did not know anything about them beyond their names, but they were all more or less pretty. Some indeed, like the copper ores, were exceedingly showy, and therefore we gave them a conspicuous place in our museum, where they filled up three or four shelves. But when the above-mentioned book revealed to us the wonder and the mystery of fossils, the minerals soon sank to a secondary place in our affections. We found them want ing in just that very particular which gave so absorbing an interest to fossils,- they had no life-story to tell. They might be pretty and showy, they might represent many and most im- 
portant branches of commerce and industry; but for all that, a Trilobite which had actually crept along the bottom of the primeval ocean, a Lingula or R.hynconella which had been engaged in the struggle for a place in the world in the very twilight of the earth's creative morning, and whose descendants had maintained it through all the vicissitudes of geological time to the present hour; a Fern that had actually formed a part of the wondrous picture we loved to draw in imagination of the tangled swamps of the Carboniferous age, was fraught with a far intenser interest than the most gorgeous mineral which had never drawn the sacred breath of life.

Our eldest brother, from whom we inherited a collection of butterflies, had also left a small cabinet of minerals; and when we began to form our museum, we found them a valuable addition by way of making a display. Afterwards, when in London, we sometimes attended the sales at Messrs. Stevens's auction-rooms, where, for a small investment, we often secured a lot which filled our pockets with minerals and our hearts with joy.

When we began to collect fossils in earnest, we never neglected to bring home specimens of all the rocks we met with in our explorations, in order to become familiar with the various formations we read of in geological books. These 
were arranged in two divisions: the ipneous and the aqueous, or unstratified and stratified-..those which had been ejected from the bowels of the earth by volcanic agency, and those which had been formed by the accumulation of sediment at the bottom of the sea.

In the first of these groups we put granite, both red and white, choosing such specimens as exhibited most distinctly the three minerals, quartz, felspar, and mica, of which it is com posed. It is the peculiar colouring of the felspar which gives the warm rich hue to red granite. Syenite, so named from Syene, in Upper Egypt, is a species of granite in which hornblende takes the place of mica. The Malvern Hills are com posed of it, and from that locality we obtained many beautiful specimens, some of them coated with greenish epidote. Of other rocks of a kindred nature, we had diorite, or greenstone, the ornamental serpentine from Cornwall, and, hardest of all, porphyry; also felspar, both in its crystallized and decomposed states. In the latter it is called kaoline, and is the substance of which porcelain is made. Our specimen was given us in the porcelain manufactory at Wor.. cester, where it may be seen in every stage of its transformation, passing from friable rock to powder, from powder to mud, from mud to clay, from clay to porcelain. The name kaoline 
is said to be the English equivalent of the Chinese word kauling, = a high ridge, the name of a hill where the porcelain clay is dug.

Basalt, a remarkably hard and compact rock, sometimes assumes, when cooling, a columnar appearance, forming, that is, huge crystals, as may be seen at the Giant's Causeway, Staffa, and also on a smaller scale near Dudley. Sometimes the stream of molten basalt forced its way through the sedimentary formations in veins, causing singular changes in the strata. Near Dudley there is, or was some few years ago, a remarkable illustration of the effect of an intrusion of basalt into a mass of coal. Wherever the molten stream had touched the coal, it had converted it into coke, and the basalt itself had assumed a white colour, as though, in destroying the coal, it had destroyed itself. A specimen illustrating this is in my cabinet.

Of the sedimentary or aqueous rocks, the first group comprises what are called metamorphic rocks, that is, those which, although of sedimentary origin, have been so changed by heat and other causes, as to appear as hard and crystalline as those of true volcanic origin. Of these we had specimens of gneiss, mica, slate, and marble. Pure white marble certainly does not look as if it had once been mud, but that it was there is no doubt. It has been 
purified and changed by fire and other agencies, Surely this is one of the parables of nature!

Of sandstones we had specimens of the Caradoc, the Old Red or Devonian, Millstone grit, New Red or Trias, and Greensand, which latter owes both its colour and name to the presence in its composition of green particles of sand of a chloritic mineral. We had also examples of Conglomerates, that is, of rocks formed, not of sand, but of pebbles compacted together. When these pebbles are small the mass is called Conglomerate; when large and water-worn, Puddingstone; when angular, Breccia.

Limestones occur throughout the whole geological series, and their family feature is the presence of carbonate of lime. Our museum contained specimens from the Llandeilo, Wenlock, Aymestry, Carboniferous, Oolitic, and Eocene formations. In addition to these, we had several sorts of Coal-Anthracite, or nonbitumenous coal; Peacock-coal, showing iridescent colours; Cannel-coal, so compact that it can be turned in the lathe, and made into ornamental articles; Curly Cannel; Lignite, or vegetable matter only partly mineralized, from the Miocene beds of Bovey Tracey; Common Coal; Bitumen; a bottle of that mysterious liquid, Petroleum; and the small part of the branch of a tree converted into jet. Also a piece 
of Amber-a fossilized vegetable gum-with an insect in it.

All these were included under the general term "rock specimens," forming a sort of neutral ground between fossils and minerals. But it was when we began to arrange and classify minerals proper that our difficulties began. To understand them thoroughly you must know not only chemistry, but also the intricate science of crystallography, of both which subjects we were profoundly ignorant. Notwithstanding, we managed to fill a quantity of paper trays with illustrative specimens.

Beginning with the metals, there was a string of Native Copper, like a miniature cluster of grapes; a flat piece of the same metal from that wonderful district on the southern shores of Lake Superior, where the very rocks seem in places turned into copper too massive and tough to be worked; Red Oxide, or Ruby Copper, and Black Oxide; Cuprite; some beautiful pieces of Malachite, or Green Carbonate of Copper, for which Russia is so famous, both the solid or botryoidal and the fibrous varieties; and also Azurite, or Blue Malachite -a most beautiful mineral. Together with these were the Arseniates and Phosphates of Copper, Olivenite, Copper Glance, Copper Pyrites, and Tennantite. 
Of Tin-the chief attraction for visitors which this island of ours seems to have had in early times-we had some Black Crystals, Pyrites, and Cassiterite, or Tin-stone, from the Cornish mines.

Then came Bismuth, used in making solder, because it melts sooner than any other metal; the showy Arseniate of Cobalt; then Zincblende; Cadmium, a mineral often associated with Zinc; and the common variety of Calamine, or Carbonate of Zinc. After these, ores of Manganese and Antimony, both white and red - the latter a very pretty mineral, looking like tufts of the finest hair.

Our specimens of the precious metals were limited to a little Gold sand, a small string of Native Silver, and some grains of Platinumthe heaviest known substance.

Of Lead we possessed several pieces of Galena (Sulphide of Lead), showing its remarkable crystallization; and some Minium, or Red Oxide of Lead. Of Iron, Pyrites; Magnetic Iron ore; Hæmatite, or Red Iron ore; Pisolitic Iron ore; common Iron-stone from the Carboniferous formation; and some Iron ore showing a crystalline structure.

After the metals came a specimen of Native Sulphur from Vesuvius; Gypsum from Staffordshire, including the finer variety known as Ala- 
baster, Selenite or Crystallized Gypsum (Hydrous Sulphate of Lime), and Fibrous Gypsum or Satin Spar; then Barytes, or Heavy Spar; Fluor Spar - a beautiful group of large cubic crystals;

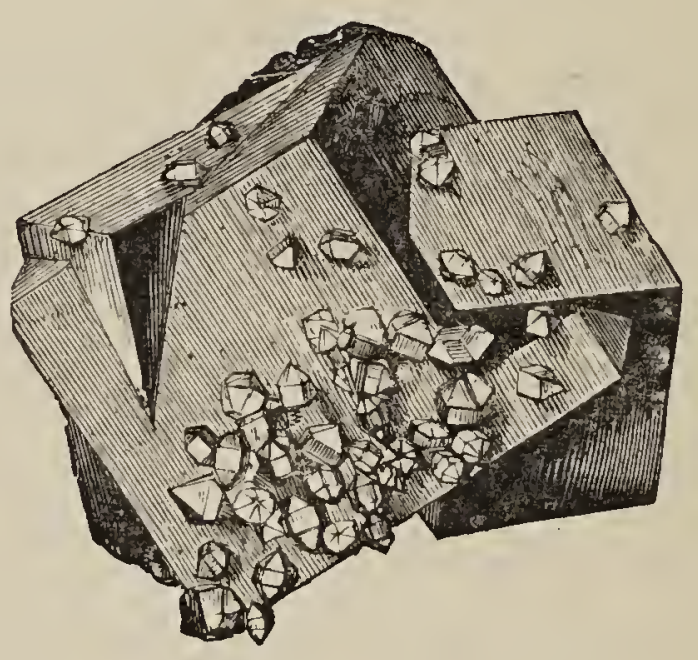

Fluor Spar.

Calcite, or Calcareous Spar; Stalactites and Stalagmite, the residuum of infiltration of water through calcareous soil (at Gibraltar, where ornaments are made of it, they call it " congealed water"); and Aragonite, a prismatic species of Carbonate of Lime. Next in order came Rockcrystal-a very pure piece from Switzerland; Quartz, Smoky Quartz; and a specimen of that lovely stone Rose Quartz, showing the most delicate blush-rose colour (I well remember our picking it up in an old muddle-shop near Drury Lane); also Chalcedony, Carnelian, and a beautiful series of Agates, which we found on the beach at Brighton, including what the Brighton lapidaries call Landscape, Moss, Sand Agates, 
and Madrepores; also Jasper and Blood-stone - the latter deriving its name, so it is said, not from its blood-red markings, but from the power which was once attributed to it of staunching blood.

Our show of precious stones, as may be guessed, was not extensive; comprising, in fact, only a Topaz in the rough; a crystal of Emerald; a piece of rock containing the very rare and beautiful crystals of Dioptase, (only found, I believe, in the Kirghese Steppes, Siberia); Garnets; and a group of crystals of Amethyst

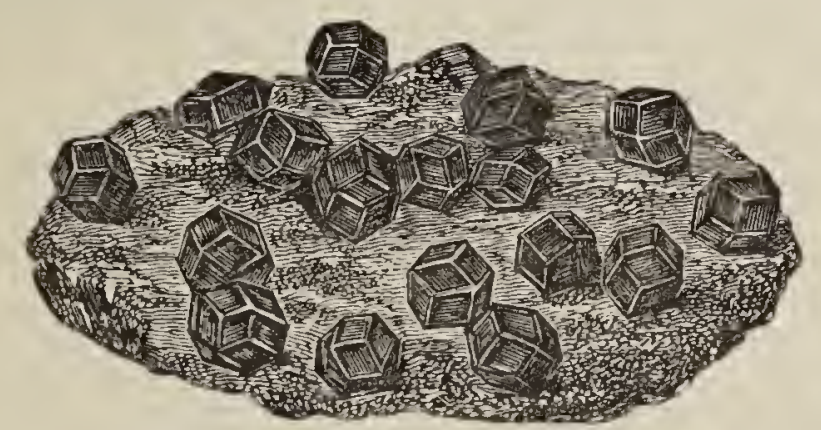

Garnets.

(from a', "not," $\mu \varepsilon \theta \dot{v} \omega$, "to be intoxicated,"-the gem being supposed to possess power to prevent intoxication). Among other anhydrous silicates, as they are technically called, we had examples of Labrador or Refracting Spar; Obsidian, or Volcanic Glass, looking like a chip off the bottom of a black wine-bottle; Lapis-lazuli, one of the most lovely blues in nature, and from which that most expensive of paints, ultramarine, is made. Its value is about five guineas the ounce, but 
happily, the artificial ultramarine, price sixpence per ounce, does well enough for most purposes. Then came Mica, Epidote, crystals of Augite, Hornblende, and that peculiar substance called Asbestos (from a, " not," $\sigma \beta \varepsilon ́ v \nu v \mu$, "to extinguish"). Few persons, seeing it for the first time, would take it for a mineral, as it is more like fibrous wood, or compressed hair. The

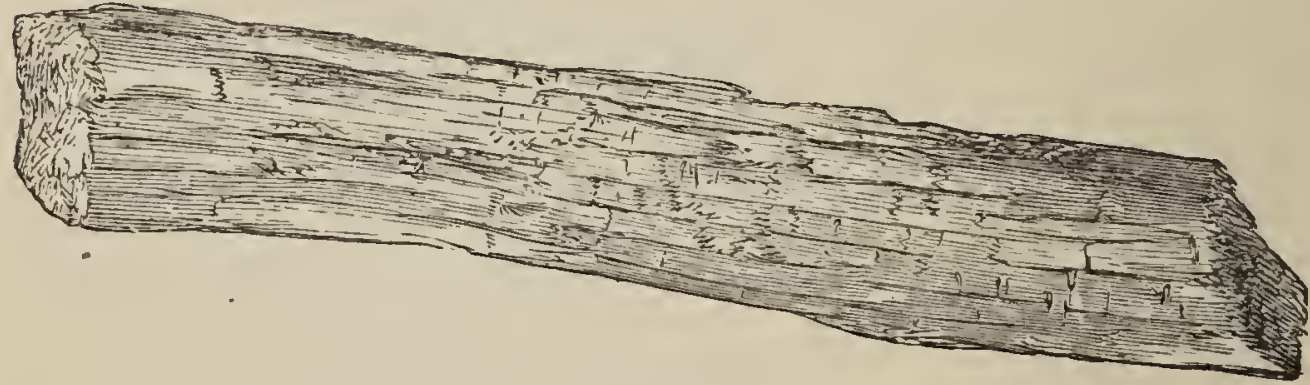

Asbestos.

Chinese, so Dana says, considered Asbestos cloth to have been manufactured of the hair of "certain rats that lived in the flames of certain volcanoes." One can only surmise that these "certain rats" must have lived upon toasted cheese, and were hunted with fire-dogs. Still, for all that, rat-hunting in the interior of a volcano must be warm work! Last of all, as examples of Hydrous Silicates, we had Talc in plates, Chlorite, Steatite or Soap-stone, and Heulandite -bought, by the way, at a sale of Mr. Heuland's minerals.

Such was our display of mineral specimens; not very extensive, it is true, but at the same time it taught us things which perhaps we could not 
have learned otherwise. We learned to regard, with admiration and reverence, the inorganic things of the earth, as fossils taught us to regard the organic; to realize that there was a world of beauty in the depths of the earth as well as on its surface, although of another description; but perhaps the lesson which impressed us most was the inexplicable wonder of the instinct of matter. The instinct of mind, or organized living creatures, is wonderful enough ; but, really I think what I must call-perhaps very unscientifically-the instinct of inorganic substances, is more mysterious still.

For example, why should one substance invariably assume the form of crystals of one form, and another substance a different one? What is there in the nature of Fluor Spar to make its crystals have their opposite sides and angles equal? Why, if Columnar Basalt is fused, as has been proved by experiment, should it, cooling, return to its prismatic form? Why should some minerals insist on having a square prism as their base? In fact, what is the instinct of matter which has laid down and cannot disobey the laws of crystallization? These are marvels and mysteries which throw a wonderful charm about the study of minerals, although they may not, like the fossils, have been fellow-sharers with ourselves of the breath of life. 
I84 THE STORY OF OUR MUSEUM.

Books.-“Mineralogy," by James Dana, A.M., one of Weale's Rudimentary Series, price two shillings, is an admirable introduction to the study of minerals. Sir Charles Lyell's "Elements of Geology" is more useful for an explanation of rocks. "Manual of Mineralogy" (S.P.C.K.). "In Search of Minerals" (S.P.C.K.). "Crystallography," by Henry Palin Gurney, M.A. (S.P.C.K.), is amply illustrated with woodcuts, and forms a trustworthy guide to the study of crystals.

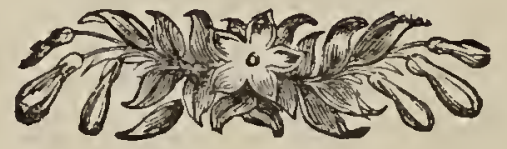




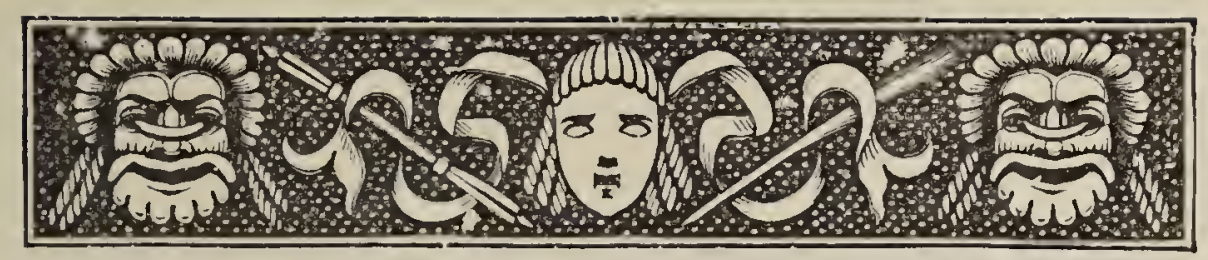

\section{CHAPTER XVI.}

\section{AUTOGRAPHS.}

wif course of time a small collection of autographs formed part of our museum. First one friend offered us a few, then another; and, since we never refused anything, we got a book, folio size, with blank leaves, into which we put them, and thus, by degrees, we obtained nearly a hundred, some being of no inconsiderable interest. It seemed to give a greater distinctness to the celebrated personages we met with in history, or read of in the papers, to see what their own hands had written. And in reading letters written by men who have made their names immortal, one seems to be admitted almost into their presence, to hear their voice, and see their face. When in London, we loved to mingle with the crowd that was always gathered before the 
autograph cases of the British Museum, and gazed with wondering curiosity upon the "marks" of the great Saxon and Norman kings. There was William the Conqueror's, who could use his sword better than his pen; another "Wm." written by the hand that wrote "Othello;" young Edward the Sixth's diary; Nelson's rough draft of the plan of the battle just commencing off the cliffs of Trafalgar; and many another treasure forming an actual part of the history of England! In contemplating these and other letters bearing the great names in literature, it is impossible not to feel one's self nearer the writers than if one only read the same things in print.

Once we summoned up courage to enter the mysterious private recesses of the Library, and asked to be shown the Rowley Manuscripts, in poor Chatterton's writing. One thing, indeed, always struck us when in the British Museum, and that was the wonderful kindness and courtesy we invariably met with from the officials of the various departments. No matter what our errand was-whether to ask the name of some rubbishy coin we had picked up, or of some common fossil or insignificant insect-had we been young princes we could not have received greater consideration and courtesy. Sometimes the gentleman whom we favoured with our little inquiries would take us from case 
to case, from specimen to specimen, teaching us more in one delightful hour than we could have learned from a month of reading; in fact, very often teaching us what was not at the time to be found in any book at all.

But to return to our autographs. We had an official document, signed top and bottom with "Charles P.;" that is, so we concluded, Charles II. Also three or four signatures of George III. to state papers of different dates; and it was melancholy to see the difference between the poor, weak autograph written during his malady, and the grand, bold, king-like "George R." of an earlier and happier date. These were all our royal autographs. Of the poets we had only two, one of them being a franked envelope of Byron. Among other franks we had Sir G. C. Lewis, Sir Hans Sloane, Lord Brougham, the great Duke of Wellington, besides a host of titled nobodies.

The following is a slip in the neat, clear hand of the celebrated Dr. Parr:-

"There is one Fault in George's Latinity, for Quando is never reflexive. We may begin a Sentence with Quando, but we cannot say, 'dies,' or 'Tempus quando.' Lowth, in his famous Verses on the Death of his Daughter, has fallen into this Error:- 
The following invitation to dinner, in the handwriting of John Wilkes, is, to say the least, out of the common:-

"I do not like either of the bow-rwood children - the elder is too grave, the younger is too wicked, and has forgotten all the promised subscriptions to the sunday schools at Kensington Gore. $\mathrm{He}$ has forgotten even the orthography of the celestial seats above, and talks only of a safe haven, where I shall never see him, and therefore would make much of him here below, and in consequence expect him to dine next sunday at the Gore, between three and four.

" thursday, Nov. I6."

We had found, amongst a lot of old papers which had been given us, some amusing manuscripts of Sir Joseph Jekyll, who was Master of the Rolls, if I recollect right, in the early part of the present century. Here is one :-

“ON MR. GREENWOOD'S GREEN DOOR IN SOUTH AUDLEY SQUARE.

" To tell a Man's Door by inscribing his Name

Was a Custom establish'd of yore,

But my Friend has contrived with his Green and his Woorl

How to tell a Man's Name by his Door. 


\section{Another is entitled}

\section{"A FAMILY DINNER.}

" Tho' thy Dinner, dear Viscount, was shabby enough, Part ragged, part raw, part rotten, part tough ; Tho' thy small single Fish, well accustom'd to Shore, Hath not seen the blue Sea for a fortnight or more; Tho' thy Lamb was as green as the Grass it had fed on, And thy Beef had an Odour enough to have sped one; Tho' thy Cutlets were cut from some dropsical Cow, And thy Cook had not heated the Carrion quite through ; Tho' thy Pickles were sweet, tho' thy Cheese it was mited, Tho' thy Wind-Falls call'd 'Peaches' the Pigs would have slighted ;

I never enjoyed a more exquisite Treat;-

Thy Wit made such ample amends for thy Meat."

\section{"ON A LADY AT BATH DETECTED IN STEALING}

\section{A BULBOUS ROOT.}

"For love of plants, which has the juster claimDarwin the Bard, or Bath's light-finger'd dame? Decide the cause, Judge Botany, we prayBe his thy Laurel, and be her's thy Bay!"

But this is the wittiest:-

"When I was confined to my Room at Paulton's last Month by the Gout, and my Nephew to his Bed by Illness; we could not meet.-J. J.

"Willy, severe and tantalizing is it When Neighbour Toe and Neighbour Hip can't visit! Two Bipeds make a Quadruped-a Bore When Quadrupeds have not one Leg in four!

"The Chelsea Pensioner at Martial Ease Gets Shade and Legs from his Horse-Chestnut Trees, 
The Greenwich Pensioner on Oaken Stumps, Like Witherington displays no doleful Dumps, Laughs at the long-lost Leg and Timber-Toe And quids the King's Tobacco ' Quid pro Quo.' Then why should you and I, dear Will, look glum, 'Tho' left, as Lilly sings, Supine in $u m$ ?

"Ye Shades of Paulton's, Beeches, Larches, Oaks! Why do you treat two Cripples with a Hoax? Within your Bark lie Legs commode and fair 'To waste their Toughness on the Desart Air;' How many useless Limbs you wave on high, For fifty Hospitals a full Supply!

Useless are Legs to you who never stalk A single Step from old Lord Mendip's Walk.

"Useless are Arms to you who ne'er indite The tuneless Trash that Album Poets write. $\mathrm{Oh}$; would your Nymphs afford one decent Crutch Such as the Belgians found would bang the Dutch, Or lend me but one pair of decent Pegs To run as well as did those Dutchmen's Legs, I'd build an Altar in each sacred GroveThe Haunt that Hampshire Hamadryads love Where they their Bacon cure, and gaily rove : Ten Legs of Pork the Sacrifice should be To Nymphs who granted but one Pair to Me!"

In the same handwriting is a table, which possesses considerable interest as showing the oratorical merits of the principal statesmen at a critical period of Parliamentary history-only six years before the passing of the first Reform Bill. 
Scale of Speakers in Parliament, Sept., 1826.

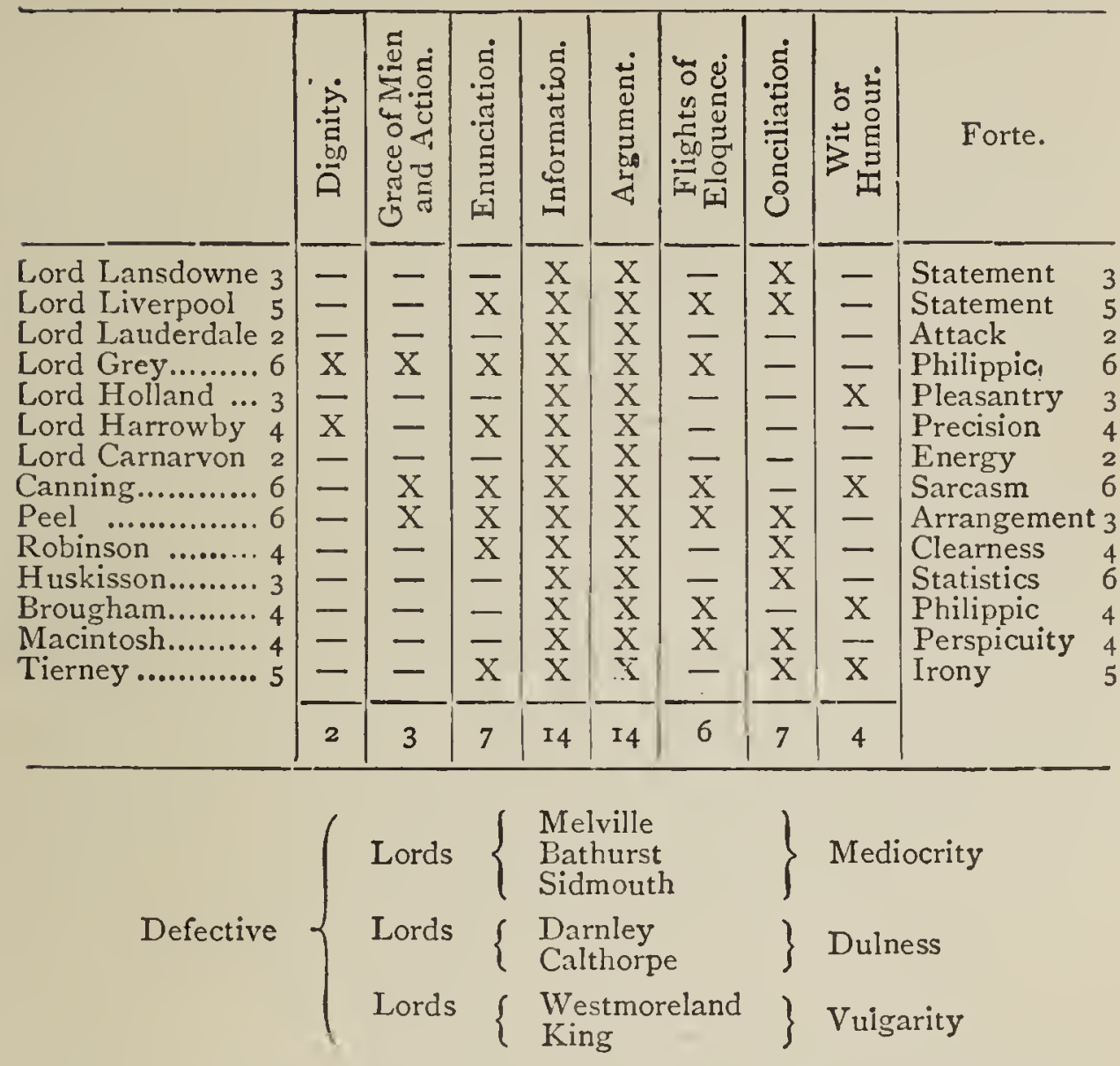

It would seem from this table, evidently carefully prepared by one familiar with Parliamentary life, that the two indispensable requisites for an orator are information and argument. Whatever else the grcat statesmen of that day might lack, they all possessed these two. Next in importance are enunciation and conciliation, both of which, however, Lord Brougham is described as wanting. Only six have marks for special eloquence.

The following letter of the Hon. Thomas Erskine, afterwards Lord Chancellor of England, 
upon the death of his wife, ${ }^{*}$ is very touching. It has neither address nor signature :-

"Your affectionate letter found me upon the bed of misery. Tho' her health was, to the view of others, plainly upon the decline, God, for some inscrutable reason, never permitted me to see it, or even to consider it as a possible event; so that it fell upon me like a stroke of thunder, but unhappily not with its mortal effect, for it has left me living. I can say nothing of what. I feel ; language has nothing that can touch it or approach it. Her whole soul was devoted to me in a manner quite unutterable. If she fell short in anything towards others, it was because there was no room in her mind for anything but me. I engrossed all her whole being, and it was my duty to have given up the world and all its concerns, and have lived only for her. But she knew, thank God, how truly I loved her, and I hope is able to see at this moment how impossible it is that I can ever be happy without her. I am afraid you. will not be able to read what I have written. Remember me kindly to Mrs. - and your worthy host.

"Lincoln's Inn Fields,

"Sunday, Decr. $29^{\text {th }}, 1805 . "$

* Frances, daughter of Daniel Moore, Esq., M.P. She died December 22, 1805 . 
How thoroughly characteristic of the man's loving nature is the following!-

\section{MY DEAR —,}

No man ever was more affectionately attached to you than I am. That you may depend on. If you are at Chambers to-morrow, call upon me; if not, I will come to you on my way from Buckingham House, about three.

$$
\begin{aligned}
& \text { "Yours most faithfully, } \\
& \text { "T. ERSKINE. }
\end{aligned}
$$

"Febr. 6, 1806."*

The following is the transcript of a letter in an official hand, but signed by James Stanhope, Secretary of State, First Lord of the Treasury and Chancellor of the Exchequer in the reign of George I. :-

" $\mathrm{S}^{\mathrm{r}}$

"I receiv'd yesterday by a flying Pacquett, the favour of your letter of the I8, with my Lord Southerland's letter to yourself. I have laid yours before the King, who is very well satisfied with your great zeal and application in his service, and very glad to hear that all the necessary preparations for the Execution of your project are in such forwardness. Having nothing at this time in Command from his $\mathrm{Maj}^{\text {ty }}$, I am

* Two months before his elevation to the peerage. 
only to wish you all possible success, and that nothing may fall in to obstruct our receiving good news from your parts.

"You will have see his Majty's speech to both houses, and their warm and vigourous resolution upon it. In persuance of which such orders are given for augmenting the Number of forces both here and in Ireland, as We hope will be sufficient to defeat the designs of the Pretender's friends in either of these Countries.

"The King approves of what the $E$. of Southerland has done in relation to Seaforth, whose submission is accepted of, provided he surrender himself at Inverness, and remain there upon his parole, of which by his Majties orders I have writt to the Earl of Southerland.

$$
\begin{aligned}
& \text { "I am, Sir, } \\
& \text { "With great haste, } \\
& \text { "Your most faithful humble serv", } \\
& \text { "JAMES STANHOPE." }
\end{aligned}
$$

The following letter from the poet Campbell, on his rheumatism, is amusing :-

$$
\begin{aligned}
& \text { "Clarence Club, } \\
& \text { "29th Dec, I840. }
\end{aligned}
$$

"My dEAR Ayrton,

"It would give me the greatest pleasure to dine with you but my Doctor has strictly forbidden me to be out after dark. Every time 
I have disobey'd this injunction my rheumatism has got worse. Of late I have taken more care of myself and I have reduced a rheumatic complaint which was once up to the scorching pointfirst of all down to the groaning and now at last down to the grunting point or pig rheumatism.

" $\mathrm{W}$ ishing however to eschew even grunting and walk only by daylight,

"With best regards to all at home,

"Yours very truly,

"Thomas CAMPBElL.."

Everything connected with Mendelssohn is so interesting, that, scrap as it is, we set great store on the following conclusion of a letter to William Horsley, the celebrated composer. It is written in a beautifully neat and clear hand, very like that of the Rev. F. W. Robertson, of Brighton :-

"With a thousand wishes for your and the whole famiily's health and happiness,

"F. M. B."

The last copy which I shall make from our autographical curiosities will be read with more interest than any of the others. We bought it at the sale of the Nelson correspondence by Messrs. Sotheby and Wilkinson, April, I853. It is the only autograph we ever bought, and cost 


\title{
I96
}

THE STORY OF OUR MUSEUM.

us eight and sixpence. It is the latter half of a letter, addressed-

\author{
"Lady Hamilton, \\ "Merton, \\ "Nelson and Bronte. \\ Surry."
}

and runs as follows :-

"however, what I have will be certain. I am glad Haslewood has rented Merton farm to Linton for another year it will give me time to think about my own affairs for God knows I have never done that justice to myself which I ought all my time and thoughts have been for the Public. I have not been so well as usual these several days past and I sincerely hope my successor is upon his rout for if they force me to stay here the Winter I shall certainly go home instead of coming out in the Spring, but a Spanish War which I fear it will be will produce plenty of Candidates. I think Lord Keith will try. God Bless you my Dearest beloved Emma. Kiss dear $\mathrm{H}^{a}$ for me.

"Ever for ever,

"Yours most faithfully and affectionat"

"NELSON and BRonte."

I need say nothing more about autographs; but I can assure any one who wishes to make a collection, that in getting up the history and 
lives of the celebrities whose writing he may acquire, he will be taught many things he might never learn any other way, and will find it a delightful way of increasing his store of general information.

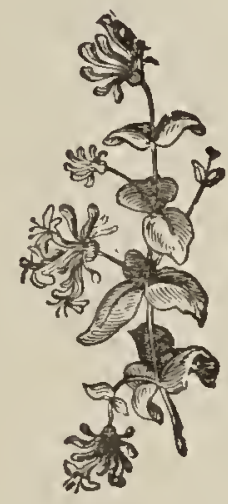




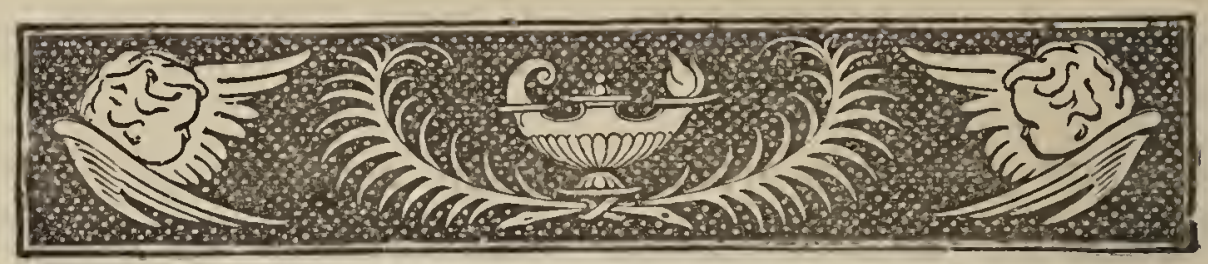

\section{CHAPTER XVII.}

POSTAGE STAMPS.

S departments of our little museum were formed that a corner was made for postage stamps, and perhaps they would never have been added at all had I not happened to pick up for fifteen pence at an old book-stall, Oppen's "Postage-Stamp Album," very fairly furnished.

The mania for collecting stamps is quite a thing of late years, but if intelligently indulged .in, may be made the vehicle for conveying a good deal of information. It is the easiest and pleasantest way of acquiring a knowledge of contemporary history and geography, and if a collection of the coinage current in the various countries from which the stamps issue accompany the album, the gain will be all the greater. Of coins I shall have something to say in the next 
chapter, but as our collection did not include many foreign ones, I may take this occasion of mentioning that they are very useful on two accounts : first, by giving one a nearer acquaintance with European and other rulers; and, secondly, by making one familiar with foreign currency-a very necessary branch of information when one comes to travel. Foreign coins are easily obtained; everybody who goes abroad generally has some on his return, and is pleased to give them to any lad who will value and make an intelligent use of them. With a few examples of the money and the stamps of each country, it is impossible not to gain some acquaintance with its history and geography.

Postage stamps, I need hardly say, are of very modern invention. They were first issued in London on the Ioth of January, I840, and for ten years were only used in England. They were adopted in France on the Ist of January, I 849; the Tour and Taxis Office introduced them into Germany in the following year; and they are now used in at least sixty-nine countries or states in Europe, nine in Africa, five in Asia, thirtysix in America, and ten in Oceania. More than fifty different stamps may be counted in the United States. Tasmania possesses its own; also Hayti, Natal, Honolulu, and Siberia.

The best way to arrange stamps in order to 
extract the most ihformation from them is to get Oppen's in expensive Album, and aim at filling it up. At the same time, they are not things to spend much money upon. Do it by exchanges. People are always pleased to give boys and girls the stamps off their foreign letters, and most boys have schoolfellows whose fathers Kave correspondents abroad, and no father/will refuse to save the empty envelopes for hlis son or his son's friend. Never refuse duplicates of stamps, or of anything else you h may be collecting, as they are always useful for e (changes. As you go on filling up your album, collect all the main facts of each country or sfate as it comes before your notice. Look it out in the map, and if you have a coin of it as Well, try to understand it -especially the meaning of the arms, if any, on the reverse. In this way geography will lose that dryness which it must inevitably have for every schoolboy, if it consist merely of a string of strange names and unrememberable dates.

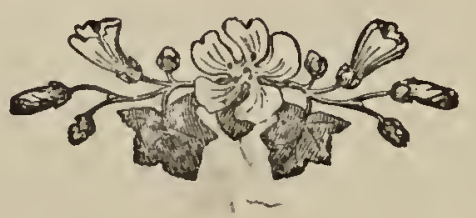




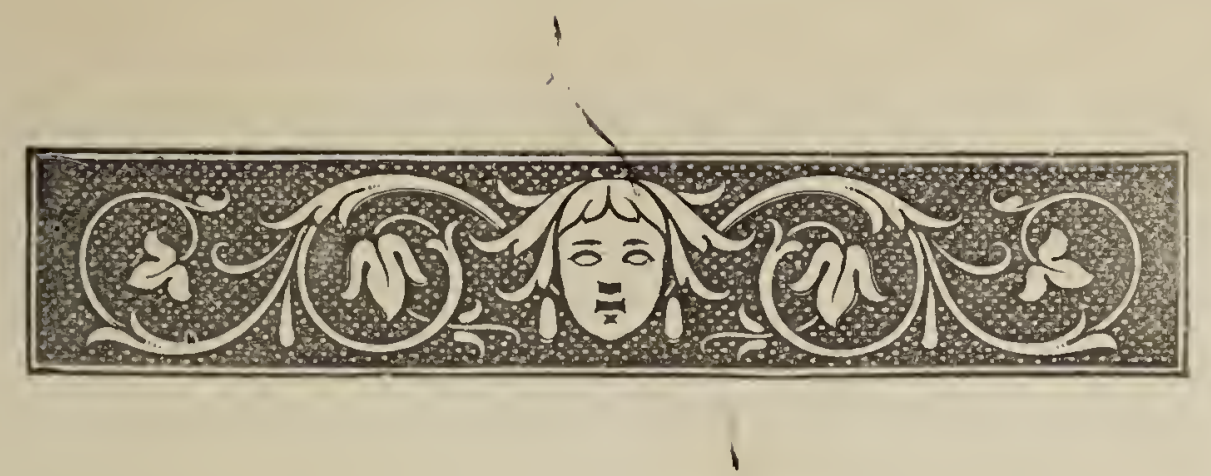

CHAPTER XVIII.

ROMANANTIQUITIES。

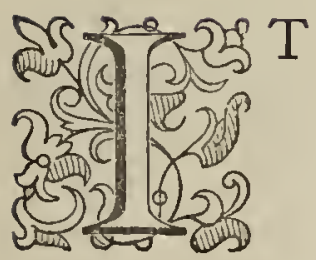

is no great wonder that we early imbibed a passion for antiquitites; the wonder would have been hä we not done so, seeing that Woodchester was itself classic ground. The remalns of one of the finest Roman villas ever discovered were the pride of the parish, and traces of the conquerors' residence abounded on all sides. Well as these conquerors could choose the most advantageous situations for their camps and towns, they had an equally keen eye for the best sites for their villas and palaces. Any one who has seen Bignor or Brading must have been struck by this, and it is equally evident at Woodchester, the site there chosen being the choicest in the neighbourhood. It is a level space on the western shoulder of the wooded hills which enclose the romantic vale of Rodborough. As you stand there, looking down on 
the valley, you see the brook, which, although now tarnished and discoloured by the refuse dyes of the cloth-mills, must formerly have appeared from this standing-point as a sparkling thread of silver winding among the willows-as sweet a spot as where the warlike god discovered poo: Silvia :-

___ "umbrosæ salices volucresque canoræ

Fecerunt somnos, et leve murmur aquæ;"

Ovid, Fast., iii. I 7 .

"Where birds invite, and warbling streams

'Neath willow shades, to quiet dreams;"

while opposite rose in graceful outlines the wooded hills of Rodborough, where now stands the picturesque mansion to which the late Earl Russell retired towards the close of his busy life. On the left, beyond the present Priory, a bright little brook has worn for itself a narrow gorge between the meadows, and runs to the larger brook of the valley, prattling of the home it has just left in the upland groves ; while behind lie the sheltering beech woods of Woodchester. One can fancy the wealthy Roman, probably some successful soldier who had seen many countries, repeating to himself, as he chose this spot as the site for his villa :-

"Puræ rivus aquæ, silvaque jugerum Paucorum et segetis certa fides meæ Fulgentum imperio fertilis Africæ;

Fallit corte beatior!"

Horace, Car., iii. I6. 
"A limpid stream-a grove of modest sizeProspects of plenty; fairer far a prize Than his who rules 'neath Afric's scorching skies;

More blest my lot!"

Here, on the very spot afterwards selected for the site of the Parish Church, one of the largest and most sumptuous villas of Roman Britain was erected. In digging the foundations for the Church and adjoining Priory, many remains of the villa must have been discovered, but they were probably regarded with superstitious horror, and immediately destroyed as heathen abominations. For, as Mr. Wright * tells us, "the early Saxons imagined that all statues and busts were implements of magic, and that the dangerous spell could only be broken by breaking them "- a superstition not yet wholly departed from country places. In later times the remains seem to have attracted some attention, and Mr. Wright mentions some old drawings made on former partial openings, but it was not until Mr. Lysons took the matter in hand, that any discoveries of importance were made. The excavations undertaken by this distinguished antiquary, extending from 1793 to I796, resulted in a complete or nearly complete disinterment of the whole villa, and the bringing

* See "The Celt, the Roman, and the Saxon," by Thomas Wright, Esq., M.A., F.S.A., M.R.S.L., etc., from which valuable work many of the above details are taken. 
to light of its beautiful mosaic pavements. It was unfortunate that the very ground covering the most important parts of the ruins should have been selected for the parish churchyard, as the village sextons have actually broken through the tesselated floor of the grand hall of the palace in digging graves. The following is $\mathrm{Mr}$. Wright's picture of the general view of the villa before its fall :-

"It covers an area of five hundred and fifty feet by above three hundred feet. The approach was by a level platform from the south, with outbuildings on the left, if not also on the right. Here the visitor approached apparently a long dead wall, with the grand portal in the centre. On passing through the entrance gateway, he found himself in an immense court, about a hundred and fifty feet square, with masses of buildings on each side. In front of him was another gateway, which led him into a second court, ninety feet square, surrounded on three sides by a gallery, or, as the ancients called it, cryptoporticus, which was, no doubt, either closed in, or capable of being closed in, as the bypocausts * under it show that it was intended to be warmed. Opposite the gate by which the visitor entered was probably another portal, that led him * I.e., flues. 
through the northern cryptoporticus into the grand hall, which was decorated with every kind of ornamentation, and perhaps with a fountain or basin of water in the middle. It is possible that beyond this there was another small court, surrounded by buildings, the foundations of which lie under the churchyard and church. It is useless to attempt to give any explanation of the mass of rooms which surround these different courts. It seems reasonable to suppose that the more elegant and private apartments were those built round the inner court. The apartments round the little side court were, perhaps, as Lysons supposed, baths and rooms for purposes connected with them. Perhaps those on the other (western) side of the court were rooms for recreation and conversing, and they seem to have been adorned with sculptures, and perhaps with pictures, ornamental pottery, and plants."

We had not returned to Woodchester more than two or three years, before it was announced that the Roman pavements were to be uncovered-a proceeding which only took place at rare intervals, when money was wanted with more than ordinary severity for parochial purposes. Of course, at the disinterring of remains so extensive, so beautiful, and so historically interesting, a perfect antiquarian fever broke out and infected the whole neigh- 
bourhood, and no one had it more severely than we two boys. For weeks together, while the excavations were going on, we thought and talked of nothing by day, dreamt of nothing by night, but the "pavement." All the other departments of our museum were neglected in the rage for antiquities. At school the only subject we could at all keep our minds to for five minutes together was Latin; but in this, inasmuch as it was the language of the men who had built and inhabited the villa, we made astonishing strides that summer. Even in Bible reading our favourite chapter, L.ev. xi., gave place to the Epistle to the Romans, which we diligently read, in the hopes that it would contain some allusions to the "pavement." Our spare time was no longer spent in fishing or butterfly hunting, but in observing the progress of the excavations in the churchyard, watching, as eagerly as any robin for worms, for fragments of pavement, bits of pottery, lumps of brick, or anything else which the spades of the labourers might throw up. Our dear old Rector must have had a hard time of it in answering the incessant questions with which we were teasing him; but the good old man, who was himself no mean antiquary and scholar, fully entered into our enthusiasm, and most patiently told us all he knew. 
Although this was so many years ago, I can perfectly recollect the general effect when the pavements were at last fully exposed. The central point of attraction was, of course, the pavement of the great hall of the villa in the churchyard. For details I must again refer to Mr. Wright, who thus describes them :-

"This pavement consisted of a central circular compartment of about twenty-five feet in diameter, consisting of an outer border formed of a Vitruvian scroll, edged on each side by a guilloche, and enriched with foliage proceeding from a mask of Pan, having a beard of leaves. Immediately within this border was a wide circular band containing representations of twelve different animals, on a white ground, with trees and flowers between them. Within this circle was a smaller band, separated from it by a guilloche and a border of acorns, and containing representations of birds on a white ground. Among them was a figure of a fox. On the southern side was a figure of Orpheus playing on the lyre. This band was bounded internally by a twisted guilloche, and within was a central hexagon, about ten feet in diameter. This centre had been entirely destroyed long before the time of the opening of the villa by Lysons, but some old drawings, made on former partial openings, show that the field was covered with figures of 
fish and sea monsters. I am inclined to think that it was a little lower than the rest of the pavement, and formed the floor of a shallow reservoir for water. The circular compartment I have been describing was inclosed in a square frame, consisting of twenty-four compartments, enriched with a great variety of guilloches, scrolls, frets, and other ornaments, edged on the inside with a braided guilloche, on the outside with a labyrinth fret, between a single fret and a braided guilloche. In the four angular spaces between the great border of this gorgeous pavement and the great circular compartment were the remains of female figures, two of which appear to have occupied each space: they had evidently been naĩads. At the four inner corners of the square were found sufficient indications that they had once been occupied by columns, which had no doubt supported the roof, which was probably vaulted. It was found that the pavement was supported by a hypocaust, or system of flues, intended to warm the room."

Besides this magnificent pavement in the churchyard, two smaller ones were uncovered in the Priory orchard, adjoining the churchyard. One of these was a representation of two boys holding up a basket of fruit and leaves, with the words BONVM EVENTVM under them, in large letters. Bonus Eventus, or "Good Luck," 
was naturally a favourite god with husbandmen-

$$
\begin{aligned}
& \text { "Eventûs belli non ignarus;" } \\
& \text { "Not ignorant of Good Luck"- }
\end{aligned}
$$

and he had an altar to himself and his obviously near relative, the Goddess Fortuna - so $\mathrm{Mr}$. Wright tells us-at Caerleon. Perhaps of all the gods and goddesses, these two have the greatest number of worshippers at the present day! In the other pavement, filling the opposite corner of the apartment, the words completing the inscription were partly visible, though much dilapidated. Originally they were $\mathrm{BHNH}^{*}$ COLITE, so that the entire sentence was "Worship well Bonus Eventus." None of the other parts of the villa, extending far into the field south of the churchyard, were uncovered at the time I am speaking of : they consist merely of masonry, without any tesselated pavements to attract the interest of the public.

The uncovering of these pavements enriched our museum with a variety of articles, which later on we should have thought poor rubbish, but which at the time were inestimable treasures. These were fragments of pavement, some containing as many as ten or twelve tesseræ cemented together, and handfuls of single cubes,

* The use of the Greek $\mathrm{H}$ for the Latin $\mathrm{E}$ is common in Roman inscriptions 
white, slate-coloured, and red, of sizes varying from an inch to about a quarter of an inch square; also a piece of the inside of one of the flues, with the soot still clinging to it, looking as if it had gathered there only the day before. One of our finds was very interesting: it was a piece of brick, bearing the impression of a finger and thumb, and set one a-thinking how many ages ago had the hand which had taken up that bit of clay before it was burnt turned into dust! Perhaps the impress of that finger-the texture of the skin was exactly preserved-was the only trace now remaining of some sturdy Roman brickmaker; and yet, perhaps, even the rich lord of the villa himself has not left so much as that! We had also many small shards of pottery, one bearing the letter $R$. We would have given our ears for a Roman vase-the one in the rectory, for example, which was found long ago, and, as tradition said, full of coinsbut Roman vases are not dug up every day, even in chesters, ${ }^{*}$ and it was not until many years had elapsed that we actually found ourselves in possession of a pair dug up at Regnum, the modern Chichester; and also what is far rarer, a perfect little lachrymatory of green glass,

* The word chester, which forms the ending of the names of so many places where the Romans established themselves in this country, comes to us from the Saxon ceaster, which, in turn, is a corruption of castrum or castra, "a camp." 
found near the same place. We discovered it in a curiosity shop, where it was described as a tear-bottle; for the old idea that the vasa unguentaria was for bottling the tears of mourners, instead of holding perfumes, is not yet dispelled. Our only other antiquarian treasures were, so far as I can remember, something we were pleased to label "A Roman axe," and a stylus from York. Of the prehistoric period, indeed, we had a splendid flint implement and a flint arrow-head: the former was eight inches and three quarters long, and seven inches and a half round the thickest part. It was found in Sussex.

Poor, however, as was the Roman department of our museum, it gave, as I said, a great zest to our study of Latin and mythology. The various figures in the mosaic pavements made Keightly sweeter than any book of fairy tales, for therein we found the stories of Pan and of Orpheus, who evidently inherited his taste for music from his mother, the sweet-voiced Calliope, and how the rivers forgot to flow, and tigers lost their savagery by the charm of his lyreaffording so picturesque a subject to the designers of the old mosaic pavements.

When we heard other boys say they hated Latin, we looked at them with surprise and compassion. We loved it, and our love for it dated from the day when we first gazed in astonish- 
ment and delight at the uncovered remains of the Roman villa at Woodchester.

Books.- "The Celt, the Roman, and the Sixon," by Thomas Wright, Esq., M.A., F.S.A. M.R.S.L. (Trübner and Co.), is a gold-mine of information upon the antiquities of our island. 


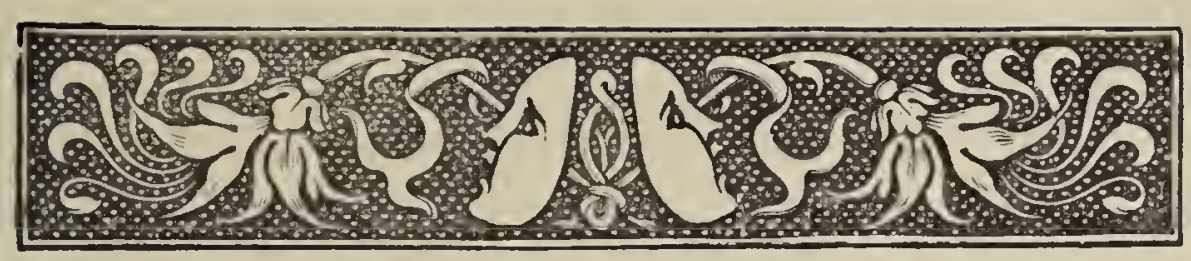

\section{CHAPTER XIX.}

\section{OUR COINS: BRITISH AND ROMAN.}

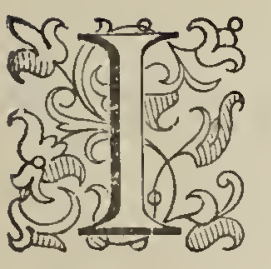

DID not mention our coins when speaking of Roman antiquities, as the subject deserves a chapter to itself. It was not for some considerable time after several other departments of our museum were begun that we were bitten by the coin mania. It happened thus. One day, as we were poking about the churchyard while a vault was being made, lying on the soil from which the turf had been removed, we espied a coin. We took it home rejoicing, washed it and scrubbed it, but could make nothing of it, save that it was a small brass or bronze, was very fairly preserved, and seemed to be Roman. As we happened to have a friend in London, an intelligent lad, and, like ourselves, fond of collecting, and who was ac- 
quainted with Mr. Roach Smith, the celebrated antiquary, we sent our treasure to him for interpretation, and in due time it was returned, with a full description, announcing, to our delight, that it was a small brass of Constantine the Great, struck at Lyons. On the obverse was the bust of the Emperor, with his name round it; and on the reverse two Roman soldiers standing on either side of an altar, with the words FLOR EXERCITVS, and some other letters. This was the foundation of our collection of coins, which in time grew to very respectable dimensions. Our dear friend and tutor, the Rector's youngest son, had a miscellaneous assemblage of coins, which he kept in an old sock, and on great occasions, or when we had got through our lessons earlier than usual, he would turn them out for our inspection, and, what was more to the point, give us some of the duplicates. Anything that might be given us we gratefully accepted, and before long found we had several dozens of coins of one sort or another, though the majority consisted of halfpennies and farthings from James II. downwards; but gradually we began to fly at higher game, and to look out for early English pennies and groats and large or first brass Roman. Ccin collecting is necessarily slow work, and it was years before we got any that a practised collector would have deigned 
to look at. Sometimes, at Messrs. Stevens's sales in London, we would buy "a speculative lot," as the auctioneer termed it, and it served our purpose well enough, for it was sure to contain many things we hadn't got, and duplicates were always useful for exchanges. Perhaps our entire collection, at its best, was worth very little from a money point of view; but if it did nothing else, it taught us history, for no sooner had we acquired a fresh coin, than we never rested until we had extracted from our school books all we possibly could of the king in whose reign it was issued-and. how could any detail of that king's reign fail to interest us, seeing that it was connected with a face we saw every time we opened our coin drawer? In this way each of our coins became, as it were, a nucleus round which the facts of history arranged themselves.

There are two ways of looking at coins: they may either be regarded as monuments of art or as evidences of history, and it is difficult to say which is the more interesting.

To examine a series of coins-say, those illustrative of English history, beginning with the rude copies from the Greek of the Britons, and passing on to the splendid first brass of Claudius, Hadrian, and Severus-what a contrast is there shown between the rude art of the conquered and the splendid civilization of the conquerors! 
Then, as we pass to the coins of the lower empire, that is, from the reign of Gallienus, how surely is the decline of the empire reflected in the decline of the coinage, until we come to the paltry brass money of the fourth and fifth centuries A.D. And when specimens of the Anglo-Saxon mint take the place of the Roman, what wretched objects of art they are, compared with pieces struck many centuries before in Greek and Roman mints! At all events, it is a suggestive fact that the Anglo-Saxon coins improve, while those of the later Roman empire grew worse and worse. The penny of Cnut or Harold II. is a higher work of art than most of the pennies of the Heptarchy. After the Norman Conquest the coinage declined. I cannot but think that a portrait was attempted, even if not achieved, on the Anglo-Norman pennies, but from the introduction of groats in the reign of Edward III., up to the time of Henry VII., all desire to represent the likeness of the king seems to have departed, as a thing hopeless to attempt-the same stiff conventional full-faced bust doing duty for all, the noble Henry V. and the villainous Richard III. alike. But in the eighteenth year of Henry VII. (I 503) art awakens; a portrait of the sovereign again appears on the coins, and by the time of Cromwell it attained, in the hands of the celebrated 
Thomas Simon, a perfection which no succeeding engraver has been able to surpass, possibly not even to equal.

The other way of looking at coins-the one which offered still greater attractions in our eyes - is to regard them as historical evidences and witnesses of the times to which they belonged, as actually parts of history; and the longer we collected, the deeper were we impressed by the feeling that we would confine our coins exclusively to such as illustrated English history only. Finding, however, that this, restricted though it was, threw open too wide and expensive a field for collecting, we reduced it still further by resolving to keep only one coin of each reign. This we soon found was much more satisfactory than gathering together a miscellaneous assemblage of anything or everything in the way of a coin, and set before us an end which we might well hope in time to attain.

Eventually our series of coins illustrative of English history, and by which I may almost say we learned English history, lay in four divisions -British, Roman, Anglo-Saxon, English.

I. The British was a very small department indeed, as it never contained more than three specimens, and at last only one. These three were the generous gift of a friend in Sussex, who had spared neither expense nor trouble in 
securing all that came to light on the neighbouring coast, where, from the numbers that have from time to time been discovered, it would seem that a British mint had formerly existed. They were all of gold, small in size, but wonderfully well preserved. The first, which we did not part with, was of the earliest type known, and therefore singularly appropriate for heading the series. On the obverse, or convex, side were those rude markings which numismatists have discovered to be the imitation of a Gaulish copy of a gold stater of Philip of Macedon; on the reverse, or concave, side was the figure of a horse, with a great star or sun above and another beneath it, and some indescribable object touching its breast. Its date may be about 150 B.C. The second was an inscribed, and therefore later coin. Obverse, the letters COMF., i.e., Comii filius = "the son of Comius;" reverse, a horse and the letters TiN. The third, also inscribed, bore on the obverse side the letters TINC., i.e., Tincomius? and on the reverse a Medusa's head. This Comius and the chief, the first four letters of whose name TINC. we are alone certain of, were apparently the contemporaries of Caractacus, the son of Cunobeline, or, as Shakespeare spells it, Cymbeline. According to Professor Rhys it should be spelt Caratacus; and, as Mr. Wright thinks, it was through 
the feuds between the sons of Cunobeline and the sons of Comius in the days of Claudius (4I54 A.D.), that Britain became an easy prey to the imperial troops under Aulus Plautius. Interesting as these two latter coins were, yet inasmuch as they did not bear the name or likeness of any recognized British sovereign, and, moreover, as they were worth at least two pounds each, we exchanged them for others of the series, reserving only the first and most ancient one.

With these gold coins before us, more particularly the earliest, the light is cast upon that well-known passage of Cæsar respecting the British coinage. It runs as follows :-

"Utuntur aut ære, aut nummo æreo, aut taleis ferreis ad certum pondus examinatis pro nummo" ("De Bell. Gal.," v. I2)—“They use either brass, or brass money or iron bars, adjusted to a certain weight, for money." This is the reading of some manuscripts, and is adopted by Professor Long, but not without misgivings, as the awkwardness of nummo areo coming directly after are strikes him as it must strike others.* But instead of areo, some manuscripts have nummo aureo, "gold coin," which certainly seems preferable, and is corroborated by the fact that

* Professor Long remarks that the words aut are seem to be unnecessary. It has been conjectured that instead of them we should read aut auro, but this reading is not supported, so far as I am aware, by any MSS. 
British gold coins of a date anterior to the landing of Cxsar are actually in existence.

At the same time, we must bear in mind that, at the period of the Roman Conquest, two distinct races were settled in Britain-the aboriginal Celts (the short-heads), who dwelt in the interior and more remote parts; and the more civilized Belgæ (the long-heads), who had appropriated to themselves the rich fertile districts of the south-east, where they could hold ready communication with their kinsfolk on the other side of the Channel.* Now, it is ascertained beyond doubt that the earliest British gold coins are not the work of the Celtic aborigines, but of the Belgic colonists, and that they took as their pattern copies of Greek gold struck in Gaul. So that either reading of the above famous passage is strictly consistent with what we know of the early history of our island, only if nummo cereo be the true reading, it refers to the Celtic part of the population; if mummo aureo, to the Belgic.

II. The Roman series in our museum was much larger and more important. We determined to get a large brass or sestertius of the four emperors who had actually been in Britain, namely, Julius Cæsar, who was in

* Other theories as to the early inhabitants of Britain are extant, but the above, which has the support of some of our best antiquaries and scholars, seems most in accordance with Cæsar's remarks on the subject. 
Britain for about three weeks in 55 B.C., and for six or seven weeks in the following year; Claudius, who landed in 43 A.D., and stayed sixteen days; Hadrian, who paid us a visit in I 20 A.D.; and Severus, who died at York on the $4^{\text {th }}$ of February, 2I I A.D. Also as large a brass coin as could be got of the succeeding
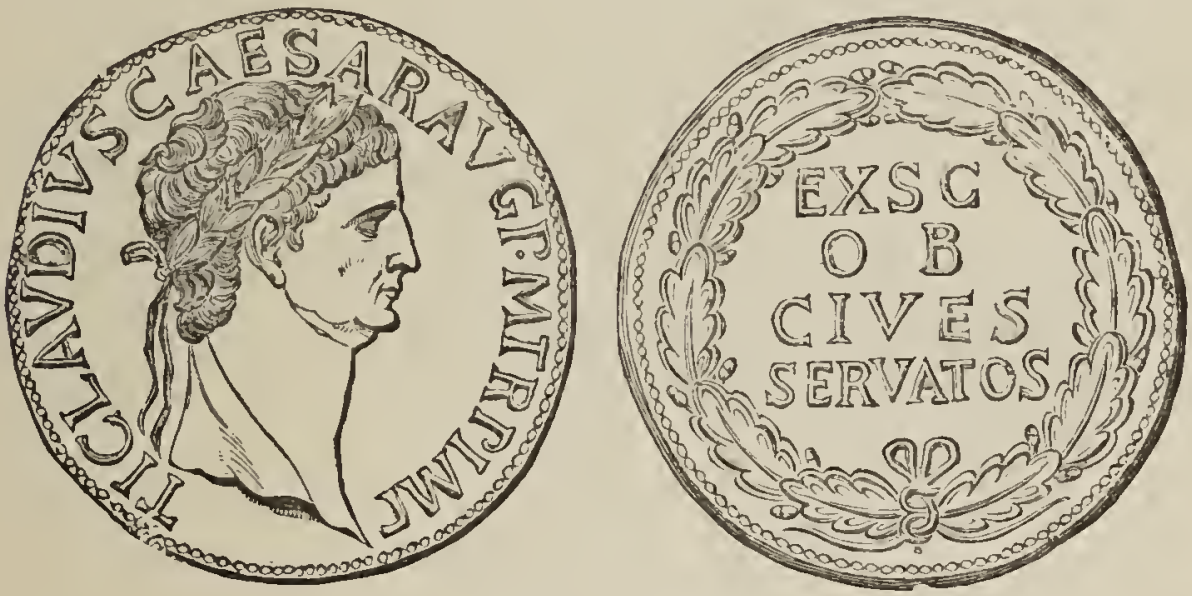

Coin of Claudius.

emperors who reigned after the rulers of the lower empire, when the larger brass were no longer issued. Also a second or middle brass of the emperors who had served in Britain before they had attained the purple, namely, Vespasian and his son Titus, who served under Plautius; Pertinax, Proprætor under Commodus; and also Albinus, the Proprætor who was made Cæsar by Commodus, and afterwards caused himself to be proclaimed Emperor, but was killed at the battle of Lyons, 197 A.D.

Had we been rich enough, we might have aimed at higher game, and included in our list 
of desiderata the Britannia type coins of Claudius, Hadrian, and Antoninus Pius; but these were too costly to hope for. The coin struck by the last-named Emperor, upon the pacification of Britain, is doubly interesting, as the reverse has the original figure of Britannia, which was adopted into the copper coinage of England in the reign of Charles II.

Accordingly, our series began with a fine sestertius of Julius Cæsar, which we obtained by

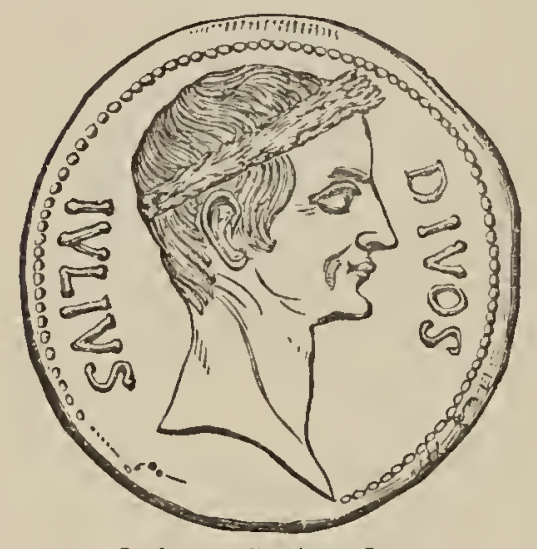

Coin of Julius Casar. exchange for a quantity of duplicates and coins not entering into the historical series. The obverse bore the bust of the great Dictator, and the reverse that of his adopted son, Augustus. Round the former were the words, DIVOS . IVLIVS. ; round the latter, CAESAR . DIVI . F., "Cæsar, son of the God."

Claudius: see fig. p. $22 \mathrm{I}$.

Hadrian: a beautifully preserved first brass or bronze, showing the head of the Emperor-a very type of manly beauty - the hair bound with a simple fillet of leaves; and on the other side, a full-length Roman soldier, holding a spear in the right hand, on either side of which were the letters S.C., i.e., Senatiis consulto, "by decree of the senate." 
Severus : first brass, a noble bearded face, hair bound like Hadrian. Reverse, a winged Victory.

Of the thirty tyrants or usurpers who split up the empire among themselves in the time of Gallienus (253-268 A.D.), Lollianus, Victorinus, Postumus, Tetricus (father and son), and Marius are supposed to have exercised authority in Gaul or Britain; and, if so, a coin of each would be necessary in a complete British series. We, however, had only a small brass of Victorinus and Tetricus, the faces of both being much alike.

One of our best coins was a small brass of Carausius, as perfect as when it was minted. The head is the beauideal of a brave, jovial sailor, such as history represents him. His story is one of the most interesting in Roman-British history. It opens at the time when the Saxons first began to cast longing eyes on our "snug little island," and to stretch out

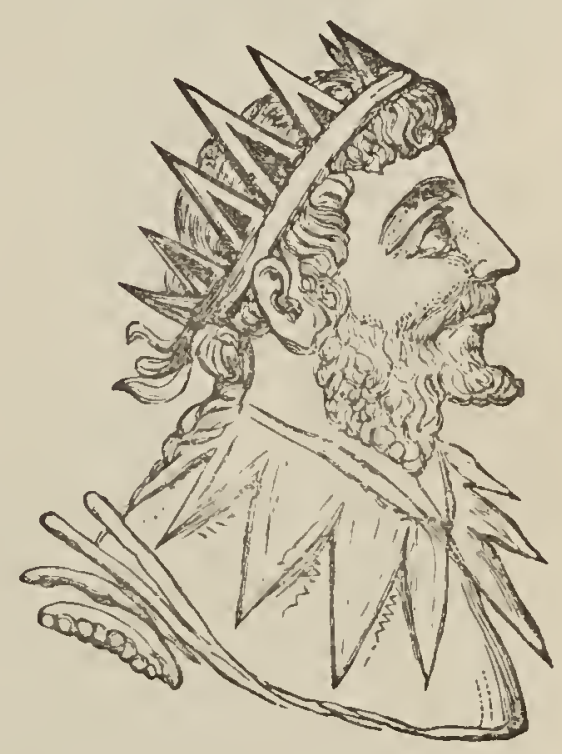

Carausius (from a coin). their itching palms to plunder it. To stop their game, the Romans manned a Channel fleet, giving the command of it to Carausius, a fine sailor, who, from being a common blue-jacket, had risen to the highest rank in his profession. Watched by 
the vigilant eye of this brave sailor, the Saxons found they had to disgorge their plunder as soon as seized; but a rumour got ashore, and travelled to Rome, that the booty thus recovered did not always find its way direct to the imperial coffers. Be this as it may, the admiral grew richer and richer, until the Emperor at head-quarters, thinking there must be something wrong about an admiral who accumulated his pay instead of spending it like a man and a sailor, mildly sent word that he was to be put to death. Strangely enough, Carausius appears to have objected to this proceeding, and cut the matter short by seizing Boulogne-the Portsmouth of the period -and proclaiming himself Emperor! But no man, especially if he be rich and powerful, is without friends, and the Emperor-admiral had. a bosom friend, whom he had assisted to rise to high office in the fleet. The name of this worthy was Allectus, the chosen.

Meanwhile Constantius, to whom as a Cæsar (i.e., heir-apparent of the empire) the command of the West had been entrusted by the joint emperors Maximian and Diocletian, came with a huge unwieldy force to reduce the self-created emperor to reason. But to catch him was obviously the first step, for Carausius was as difficult to catch as a conger, and, slipping out of the port of Boulogne, ingeniously added to the vexa- 
tions of his pursuer by blocking up the entrance with piles and stones; and Constantius the Pale grew paler than ever as he stood upon the abom. inable obstruction, and watched the ships of the admiral gaily passing up and down the Channel with the Saxon galleys, deep with plunder, in tow.

How the difficulty between the two commanders might eventually have been arranged, it is impossible to guess had the affair gone on ; but alas! Carausius, like another Julius Cæsar, had his "Brutus," in the person of the equally "honourable" Allectus. One day, the brave admiral found himself suddenly stabbed to the heart, and turning round on the assassin, saw it was the friend and shipmate he had loved, trusted, and raised to honour! He may have had just time to say his "Et tu, Allecte!" when

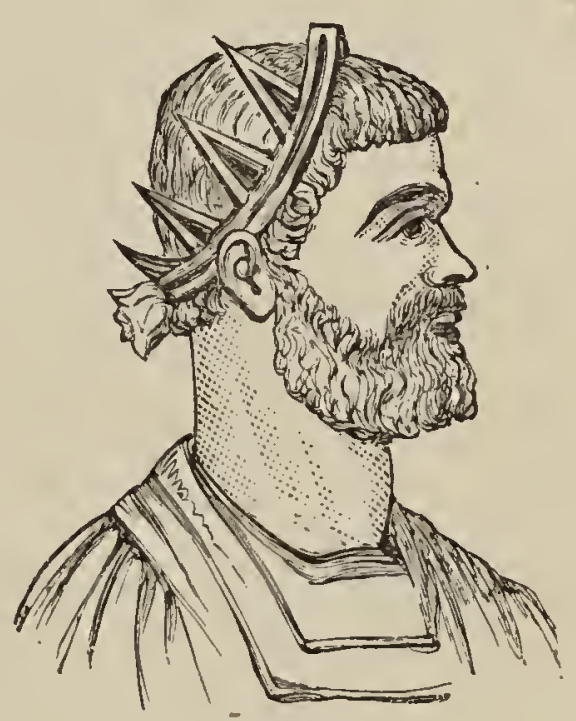

Allectus (from a coin). he fell a victim to the ruffian's cruel and perfidious ambition.

The only satisfactory part of the story is the retribution which overtook the murderer. For three years he sat on the throne his wicked soul had coveted. Whether his life during those three years was as happy as he had anticipated; 
whether there were no pangs of remorse by day, no haunting presence of his blood-stained victim by night, history does not inform us. It is a story Shakespeare might have dramatized. At last (286 A.D.) the messengers of vengeance were ready. At Boulogne, the harbour had been cleared, and there lay a squadron of Channelcrossing galleys, while another and yet larger expedition was waiting for orders at the mouth of the Seine. Constantius and his admiral, Asclepioditus, were with the former. Both weighed anchor at the same time, but a thick sea fog coming on, some of the ships lost their way, and eventually sailed up the Thames to London. The others, with the Cæsar and Asclepioditus, made for the coast near Portsmouth. Anticipating this, Allectus had stationed his fleet near the Isle of Wight, to intercept the enemy. But the powers of the world of nature ranged themselves on the side of the avenger against the murderer. A thick fog enabled Constantius to bring his forces to land without any hindrance from the squadron on the look out for him, and landing, like Taric when leading his Arabs into Spain, he burnt the ships that brought him over. Allectus, probably at Yortsmouth, heard with dismay of the nearness of the dreaded foe. He instantly commenced to march inland, pursued by the Romans. The 
actual spot where the battle, which restored Britain to her former masters and avenged the blood of Carausius, was fought, cannot be pointed out with certainty; but many circumstances make it very probable that it was in the immediate neighbourhood of Selborne, in Hampshire.*

We had a coin of each of these worthies, the one bearing the fine, bluff, sailor-like face of the admiral; the other the bullet-shaped head and cruel features of the friend who was so ready to slaughter him that he might seize his crown.

Of the Constantine family, we had a fairish second brass of Constantius Chlorus, or the Pale, who died at York, on the 25 th of July, 306 A.D.; and of his more illustrious son, Constantius the Great, who remained in Britain some six years after his father's death had given him the imperial throne. His coins

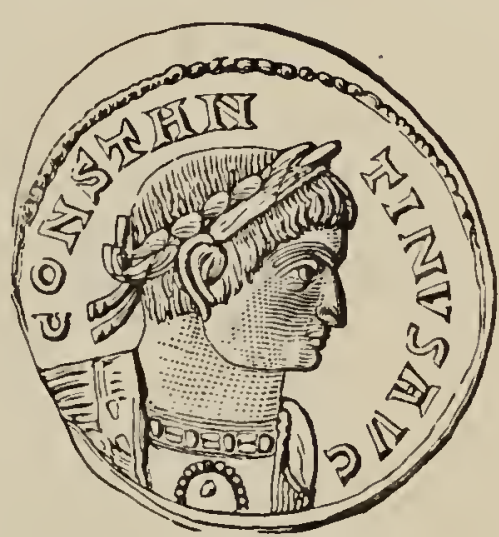

Coin of Constantine I. are by far the commonest of the Roman-British series. One of ours, found at Chichester, bore on the obverse the helmeted head of Mars, with

* In relating this coin-story, I have followed Lord Selborine rother than Mr. Wright. See Professor Bell's edition of White's "Selborne," Appendix on the Roman-British Antiquities, by Lord Selborne. 
the words, URBS ROMA; and on the reverse the wclf suckling the infants Romulus and Remus -a picturesque record of the familiar legend. Above the wolf were two stars, which I do not know the meaning of. This was one of the types introduced at the time of the dedication of Constantinople, in 330. Passing to his son Constantius I., we had a small well-kept coin, with the Emperor's head on one side, and a bird standing on what looks like a rock

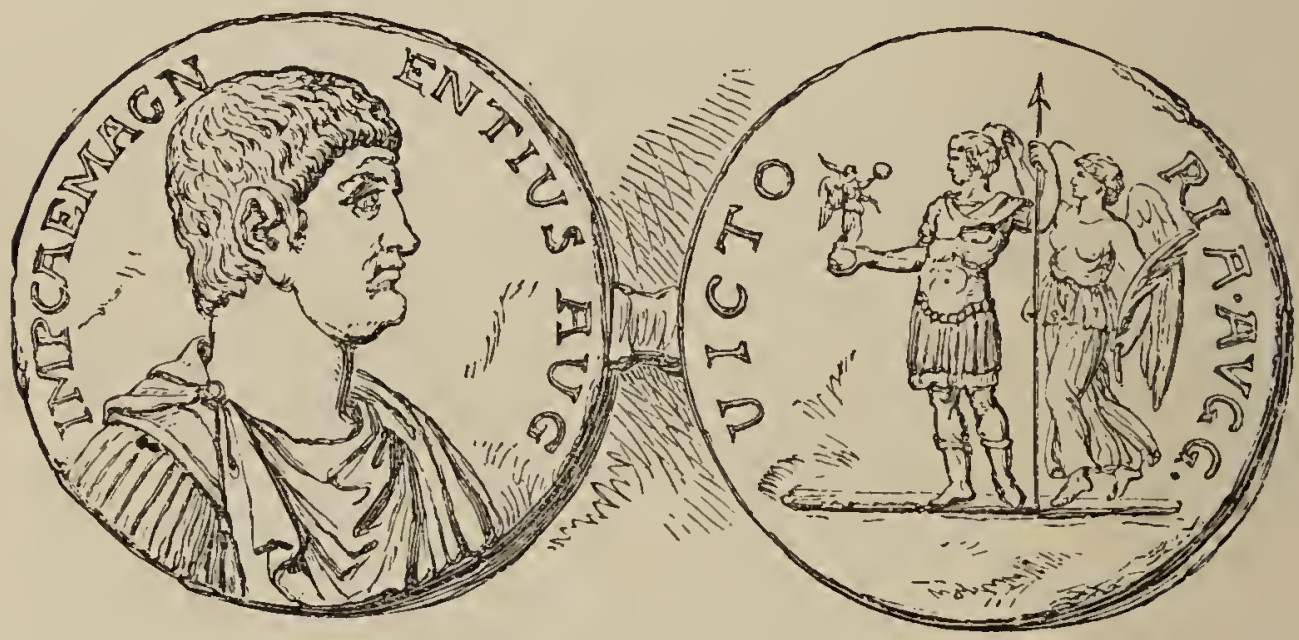

Coin of Magnentius.

on the other. Although not strictly within our prescribed limits, inasmuch as Constantius II. is not directly connected with British history, we had not the courage to turn out a bcautifully preserved coin of his, because it bore on the reverse the Christian emblem-its first appearance on the coinage. It shows the sacred symbol thus: $\mathrm{A} \mathbb{R}_{\Omega}$, with the Alpha and Omega at the side, showing that it may have been struck 
between 350 and $353^{*}$ The last of the family who figures in the annals of our island is Consiantius I., who paid a visit to Britain in 347 , and was assassinated, three years after his return, by Magnentius, one of his officers, repeating, as it seems, the tragedy of Carausius. On his coin the face of this murderer has just the morose, bull-dog expression one would expect of such a man.

The next in the series was a coin of Magnus Maximus, who had usurped the western division of the empire from Gratian upon the elevation of Theodosius the Great. For a time fortune smiled upon the usurper; the troops in Britain unanimously supported his cause, and crossing over to Germany, he found himself equally in favour there, and in a short period crowned his success by the murder of Gratian. Flushed with victory, he crossed the Alps, and entered Aquileia, where the armies of Theodosius overtook him, and immediately put him to death. The last resident ruler whose coins come into this series was Constantius III., a common soldier, who was elected merely because his name happened to be Constantine, for he was no member of that imperial family. He was beseiged and put to death at Arles by the troops of Honorius,

* See Art. "Money," by Frederic W. Madden, in Smith's "Dictionary of Christian Antiquities," vol. ii. p. 1287. 
that emperor having, in the preceding year, 410 , granted the people of Britain their independence. A coin of Honorius appropriately closed the series, illustrating the history of Britain under the Roman rule. 


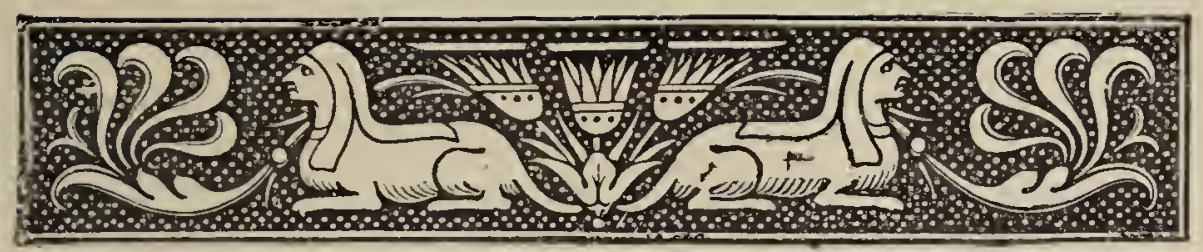

\section{CHAPTER XX.}

OUR COINS: SAXON AND ENGLISH.

Fur $\mathrm{F}$ our little collection of KomanBritish coins gave us an interest in a portion of the history of this island generally looked upon as dry and barren, a full series of Anglo-Saxon coins, had we possessed it, would have done the same with that still worse confused and difficult period which extended from the grant of independence in A.D. 4IO to the Norman conquest. As it was, we learned a good deal by merely making lists of what we should like, and reading in the catalogues of the sales of coins which we could not afford to attend.

III. This part of our historical series began with a couple of minimi. Minimi is the name given to those rude imitations of Roman coins which the people, after the final departure of the 
Romans, struck in order to provide themselves with some medium of exchange. Mr. Wright says they are of historical interest, because they seem to show the continued existence of the municipal government in the towns. One of ours was dug up at Chichester, and is copied apparently from a third, or small brass of Constantine. These coins are the connecting link between the Roman and the Anglo-Saxon.

The earliest mintage of the Saxons consisted of small silver coins, also generally imitated from Roman, called sceattas, sceat or scet being AngloSaxon for money or tribute. I don't think we ever managed to get one. We had a few stycas, those little coins of mixed metal which were only struck in Northumbria. The word sticce means a small piece or part, and two were equivalent to a farthing. Silver pennies, which continued, with occasional half-pennies, to be the only coin current in England till the reign of Edward III., first appear with certainty in the time of Eadbert, King of Kent, from 794 to 798 . Kent, Mercia, the East Angles, and Northumbria were the only kingdoms of the Heptarchy that issued them, and of these the Mercian coins, especially those of Offa, are the most beautiful. There is an explanation of this. Offa, after the foul murder at Hereford of Ethelbert King of the East Angles, on the eve of his marriage with 
Offa's daughter, the Princess Elfrida, made a pilgrimage to Rome, to obtain papal absolution for his crime. There, in the centre of Western civilization, he may have imbibed or increased some taste for the fine arts, and on his return brought with him skilled artists to improve his coinage. To possess an Offa was an ambition we never realized, as indeed was the case with most of the Anglo--Saxon coins.

The series of the sole monarchs begins with Egbert, or, as it is engraved on his pennies, "Ecgbeorht," although it is well known that the kingdom was not firmly and finally united until the reign of Edgar. Coins of all the AngloSaxon kings, with the exception of Ethelbald and Edmund Ironside, are in existence, but some are very rare, and consequently very expensive, especially those of Egbert, Ethelred I., Harold I. and II., and the Danish Harthacnut. In fact, the commonest of the series, Cnut and Edward the Confessor, are worth at least five shillings apiece, so it was no wonder that our collection did not advance beyond these two. I only once heard of an Harold II. within reach, but it sold for twenty-eight shillings. It is a coin of the greatest historical value, as closing the Saxon series, besides giving us a contemporary portrait of the uinfortunate king who fouglit so heroically at Senlac. 
IV. English. This fourth and last division of the historical series begins, of course, with the pennies of the Conqueror. They are of many types, but the commonest, and as I think by far the most interesting, are those cailed the "Pax" pennies, from having the letters PAXs in the angles of a cross on the reverse. It would seem that this word Pax, which means (I) "peace," (2) "compact or agreement," and which appears on some of the coins of Edward the Confessor, Harold II., William the Conqueror, and Rufus, has reference to two very opposite compacts. On the coins of the Confessor it is believed to refer to the compact or agreement which that monarch made with Earl Godwin, that the son of the latter should succeed to the kingdom; in which case we can at once understand why it should have been adopted by Harold, the son of Godwin. On the other hand, upon the Conqueror's coins, it may have reference both to the agreement which, according to William of Malmesbury, Edward made with him, promising the inheritance to him; and also to the oath upon the relics, which he extorted from Harold. So these "Pax" pennies are historical records of the very highest interest. On one minor point the minds of numismatists appear to be much exercised: on the pennies of the Conqueror "Pax" is spelt raxs. What does the $\mathrm{S}$ mean? 
Folkes suggests that it stands for subditis, "subdued," referring either to the subjugation of the kingdom, or of some particular city in which the coin was struck. For my own part, I should explain it in a much simpler way. The word PAX only contains three letters, yet it had to fill the four angles of the cross, so the problem to be solved was how to fill up four corners with three letters, and it was solved by the very obvious device of inserting some letter in the fourth angle, which should not interfere with the sound of the word when pronounced. The Confessor's moneyers got over the difficulty by spelling it PACX or Paxx; but whether spelt "Pacx," "Paxx," or "Paxs," the pronunciation is the same, and that was quite enough to satisfy the phonetic requirements of those days. *

We were very proud of our Rufus penny. It was a very fine one, and-not that we thought any better of it for that-of a very rare type (Hawkins, 244). We got it in exchange for one of our three small British gold, and the dealer who let us have it, well known for his moderate prices, as well as for his liberality in the matter of exchanges, and courtesy on all occasions, $\dagger$ had priced it at two pounds ten shillings.

* In Roman-British inscriptions $x$ is frequently written "xs." -Hübner.

+ W. S. Lincoln and Son, 462, New Oxford Street, London. 
Our Henry I. did not cost us nearly so much. One day, as we were exploring an old rubbish shop, asking of the woman who kept it if she had any coins, she produced a bag, which she emptied into a plate, ex. pressing her conviction that there was "nout there." But among the farthings of George IIJ., tradesmen's tokens, and brass buttons, we picked out a little coin we had never seen before, and quickly paid the sixpence at which the old lady priced it.

On getting home, and giving it a scrub with a little eau de Cologne and tooth-powder, we could read it more clearly. It turned out to be a Henry I. penny, of a very rare type (Hawkins, 264), bearing the profile to left with a rose in front, and the legend + HENRICVS RE. On the reverse was a cross, with an annulet in each angle. Now, as I have said before, we had made it a rule to prefer goodness of preservation to rarity of type. We only kept one specimen of each reign, but that one we tried to get as good as possible, especially a good portrait, or what was meant to be a portrait, of the king. Showing our new find to an experienced collector, he at once valued it at thirty shillings, and offered us another Henry I., equally good as to preservation, but of less rare type, together with a Richard III: groat (a scarce coin), and one or 
two others. I mention this as an illustration of the way in which we formed our collection, namely, by studying the subject sufficiently to know a scarce coin when we saw it, and, if we could buy it cheap, exchanging it for others we wanted more.

As a rule, all the pennies of Stephen are either poorly struck or badly preserved, and ours was no exception to this rule, although it cost us twelve shillings. In all these AngloNorman pennies an attempt seems to be made, however rudely executed, at producing a portrait. The Conqueror, stern and grim, looks one full in the face, grasping in the right hand the sceptre of his newly acquired kingdom. Rufus, with his sword drawn, looks hot and hasty, like most gentlemen of an extremely florid temperament. Henry I. appears muck. more like a refined gentleman, and his bust justifies his claim to the title of "the Beau Clerc." Stephen is simply a stolid-looking soldier. As, however, we pass on to the Plantagenet pennies, the likeness becomes an evident failure. Cœur de Lion did not coin money bearing his name and bust, and in place of the latter the Crusader's cross appears on the obverse of his pennies or deniers, for they were all struck in France. Ours had the letters PICTAVIENSIS (Poictou) arranged in three lines on the reversc. 
The series of groats* commences with Edward III. $\uparrow$ and continues to Henry VII., who, in his eighteenth year (1503) coined the first English shilling. $\neq$ These groats are all alike, save to the practised eye of the numismatist, and are the most uninteresting part of the whole series. 'They all show the same conventional full face, with the hair sticking out on either side, the very idea of attempting a portrait having utterly died out. Some, however, are rare and expensive, especially the two Richards, and I never could understand how it was that the groats of Richard II., who reigned twenty-two years, should be as scarce as, if not scarcer than, those of Richard III., who only reigned two. Groats believed to be of Edward V., who sat on the throne from April 9 to June 26, I483, are sometimes to be met with. They are like those of his father, but with the boar's head, the cognizance of his uncle-kin but not kind-as the usual mint-mark. This and Richard II. we never acquired.

We possessed all the Tudors, but had to put up with groats of Henry VII. and Henry VIII.,

* It may be well to mention that this word is pronounced grawt, the oa following the usage of the same letters in the word broad.

$\uparrow$ Edward I. struck a pattern groat.

† The shilling was (theoretically) a division of the pound, and is probably derived from the A.-S. scylan, "to divide." 
for the simple reason that a shilling of the former is worth from ten to fifteen pounds, and a good one of the latter cannot be got for less than one pound. We had a beautiful shilling of Edward VI.; a groat of Mary, who did not coin shillings, except in Ireland; a fine shilling of Philip and Mary, the two busts facing each other-

"Still amorous, fond, and billing,

Like Philip and Mary upon a shilling ;"

as Butler sings; and a shilling of Elizabeth, who, it is said, would allow of no shadows in her painted portraits, which may account for the extreme lowness of the relief of the bust in her coins, and in all that I have seen they are very slightly raised above the field of the coin. The Stuart and Hanover coins are mostly common, but as, after Charles I., the shillings were reduced to their present size, we completed our series in half-crowns, of which the only one at all difficult to get is George I. Of the Common wealth we had a shilling-a miserable object compared with the grand coins of Cromwell, to whose half-crown we aspired in vain: both this and the crown are the work of the celebrated Thomas Simon, and are justly regarded as crowning triumphs of the engraver's art. Our series closed with that magnificent piece which, on account of the costliness of its production. 
was never issued for circulation-the Gothic crown of Queen Victoria.

A series of the coins of England is, in fact, the history of England, and I can truly say we learned our history through our coins. There is no reason why any boy should not succeed in forming a complete series if he will be content with one coin only of each reign, and be indifferent as to type. We did what we did mainly by exchanges, by taking everything that might be given us, and by hunting about in curiosity shops, and, when we found a coin of rare type, exchanging or selling it, and so getting another of a commoner type and other coins to boot. Such rarities as a Chester penny of Edward I., groat and half-groat of Henry IV., groat of Edward V., half-groat of Richard IIl., penny and half-groat of Philip and Mary, or a Cromwell sixpence (which has sold for as much as thirtyfive pounds), we were always on the look out for. As a rule, the curiosity dealers and jewellers understand nothing of all this. They simply buy the coins for their value as old silver, and it pays them to sell at a small profit; but a few such finds go a long way towards completing the series. Then there is another advantage about coins: as education advances, and their historical interest becomes better appreciated, the numiber of collectors increases, but not the coins. 
and therefore the latter must rise in value; so that if you should ever want to sell your collection, you may be sure of getting more than you gave for it. They are not cumbersome like fossils, perishable like butterflies, or fragile like shells; and if kept under lock and key in a safe place, they are as sure and profitable an investment as any lad can desire.

And this brings the narrative of our museum to a close. I have endeavoured to conduct you, my dear reader, through all its "departments," although it was contained in a room some twelve feet square. I have shown you everything; told you how we came by all our specimens - how the collecting of them was the passion of our boyish, the remembrance of them the pleasure of our maturer, days. The only thing I have not told you is the varied information we insensibly acquired while gathering or studying our specimens, or how it wove itself into and coloured our after lives. But of all the benefits we derived from such pursuits the greatest was the habit of observing - the making use of our eyes, and not going through the world blind and deaf to the lovely things which lie around us all in our daily path, the many voices which speak from all the works of God's creating hand. It is impossible to love 
these, and stop short at loving them. The mysteries of the natural world are the parables of God, and the mind that gets into the habit of communing with these, stands nearer to the Father of all, and learns insensibly to connect His presence with the beauty and the wonder of the works of His hands. With this thought upon the heart as you ramble about the hills and woods, you will feel something of that reverence which falls upon you as you enter some majestic cathedral; and the deeper you examine into the wonders of the natural world, the more profound will this feeling become. In a word, the early study of nature not only bears fruit upward in the intellect, but strikes root downward in the heart.

Books.-The first book to get for the study of the English coins is unquestionably Henfrey's "Guide to English Coins," etc. ; while for a comprehensive view of the whole subject of numismatics, including Roman and Anglo-Saxon coins, Humphrey's "Coin-Collector's Manual" (Bohn) is most valuable.

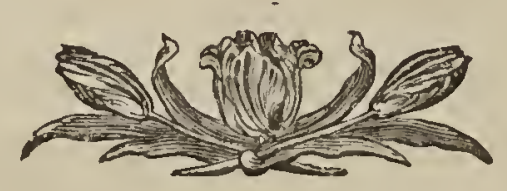




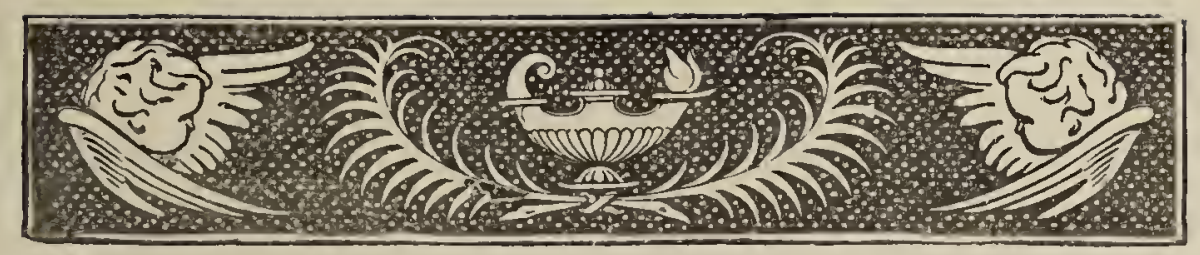

\section{CHAPTER XXI.}

\section{CONCLUSION.}

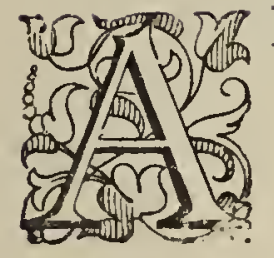

ND now the story of our museum is told. Although it comprised many departments, it must not be supposed that all were commenced at the same time. One thing led to another, and our borders enlarged by almost insensible degrees as we went on. At starting we had, as I have already said, some inheritances from an elder brother, consisting of a few minerals and fossils, and a collection of insects, and these we added to until they became sufficient to illustrate the leading outlines of mineralogy, geology, and entomology. Our own original collections began with birds and their eggs, followed by a few stuffed fish. It has not been worth while to speak of our stuffed quadrupeds, as we had only five or six in all - to wit, a Fox, which from 
some unexplained cause caught the mange soon after we had stuffed him. All his hair dropped off, and a piece of wire, with some shrivelled skin on it, was all that remained of his once bushy brush. Then there was a Hedgehog, from

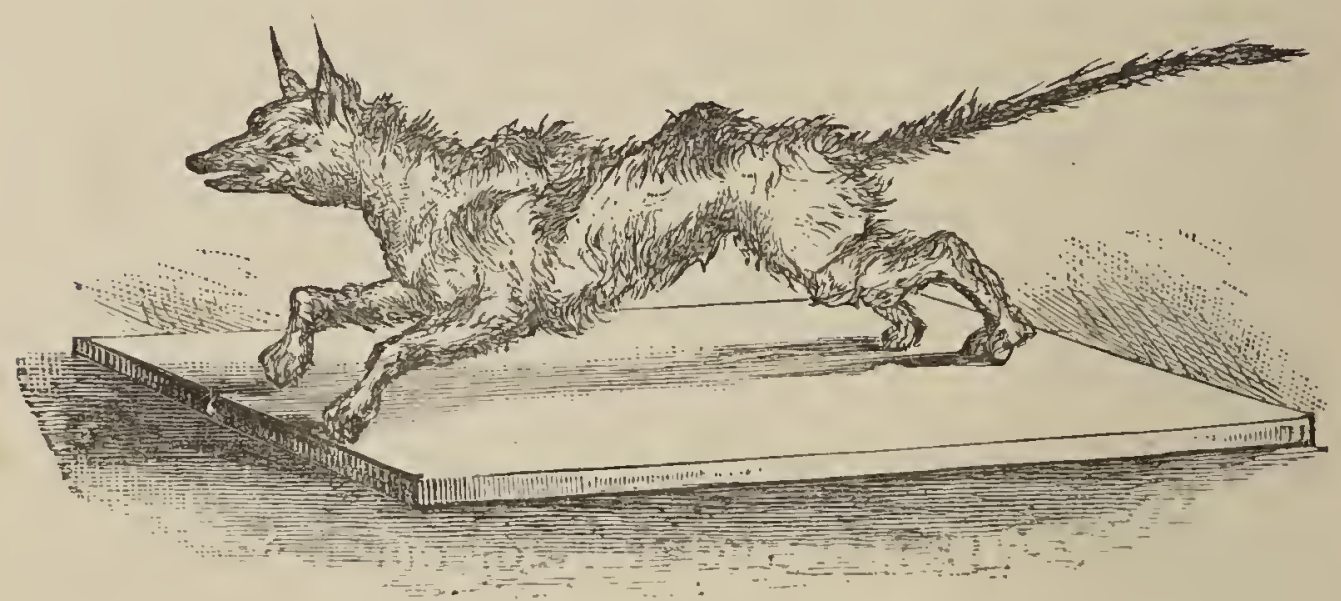

Our Fox!

the stuffing of which our hands did not recover for weeks; a Bat or two; and a Weasel. Once, indeed, a friend sent us a Polecat, which we began to skin; but although we plugged our noses with cotton, the stench was so utterly intolerable, that we buried the beast in disgust long before the operation was completed. So the less said about the mammalia department the better; - it was a failure.

Next in order of time came the present of sea-shells, after which we began to collect the land-shells of our own neighbourhood; then the dried flowers; while it was not until we häd collected for some years that we seriously 
applied ourselves to geology and study of fossils. Roman antiquities were one of our earlier subjects, in truth they were almost forced upon our notice by the mere fact of living at Woodchester. Every time we went to church the level depression on the left-hand side of the churchyard, with the base of a Roman pillar rising above the turf, reminded us of that glorious tesselated pavement lying beneath, which at last our eyes had the happiness to see uncovered.

About the last things we turned our attention to were autographs and postage stamps; and although we began early to think about coins, it was not until many years afterwards that our collection assumed the form of a regular historical series.

Now, were I asked, on looking back at these amusements of our boyhood, what we learned by them, I should say that coins taught us history; postage stamps, geography; and autographs, biography; while the general handling of specimens, stuffing birds, laying out butterflies, arranging shells, writing labels, etc., all taught us method, neatness, and nicety of touch. The pursuit of birds and their eggs inculcated endurance and presence of mind in the minor perils of boyhood; while the constant habit of looking for our recreations and pleasures 
to the world of nature begat within us a certain sympathy with everything we found there, and a reverence for the wonderful beauty we saw in everything we examined. As for the feeling of disgust which some people feel at this or that insect or reptile, we could not understand it; and the habit grew upon us of feeling there was sure to be something worth seeing and knowing even in the humblest weed or snail.

But before concluding I will just recapitulate the lines upon which we worked in forming our museum, and offer a few hints to those who may wish to follow in the same course. Since our facilities for acquiring specimens were limited, and money to spend upon them scarce, the following were the two main principles we observed.

I. The first and most important was the principle of exchange. It is impossible to collect for any length of time without an accumulation of duplicates. Now, since we never kept more than one, or one pair, or one tablet, as the case might be, of anything, the duplicates came in useful for exchanges. Almost every neighbourhood has some speciality in the way of natural history-that of ours was Oolitic fossils-and with these exchanges can be made for the specialities of other neighbourhoods. Once I 
was offered a fine series of Red crag fossils for duplicate postage stamps, and frequently a rare bird's egg or land-shell will find a willing exchanger for a good coin or fossil. In this way we made one branch of our museum play into the hands of another.

II. The other means upon which we relied for things which our own neighbourhood did not produce was hunting in old curiosity shops whenever we had the chance. In this way we picked up many a rare mineral-Dioptase, for example-and sea-shell, to say nothing of coins ; and whenever we happened upon anything which we knew could be exchanged or sold again with advantage, we did not hesitate to buy it. Also, when in London, we used to attend the curiosity sales at Messrs. Stevens's, and often at a ridiculously low price got a great trayful of fossils or minerals, or a handful of old coins. The excitement of bidding for these, and of arranging and naming them when got, was one of the supreme joys of our boyhood.

To those who may feel inclined to follow in a similar course of collecting, I would offer the following pieces of advice as the result of our own experience.

I. Collect, or rather keep, within narrow limits. The more subjects you aim at, the 
more is your museum liable to become unsatisfactory, and your own knowledge superficial. On looking back at the museum I have been describing, I feel sure we should have done much better in every way had we undertaken fewer subjects and mastered them more thoroughly. The result of our diffuseness was that, while we knew something of well-nigh everything, we knew nothing thoroughly and well about any one. At the same time, I would not discourage a general knowledge, or a general collecting which assists in gaining it; but at the same time would advise you to have one special subject which you are resolved to study to the very bottom. The well-known lines-

\section{"A little knowledge is a dangerous thing; \\ Drink deep, or taste not the Pierian spring"-}

are too often accepted without the qualifying grain of salt. A little knowledge is only dangerous when you mistake it for a large knowledge, and act accordingly. The knowledge I acquired in boyhood of most of the subjects on which I have been speaking, little as it is, has proved a source of many pleasures. It has enabled me to take an interest in and derive instruction from other people's collections of whatever kind they were, and to meet their possessors on their own ground; it has infinitely 
increased the charms of travelling; and has been the means of bringing me into personal contact with some of the greatest scientific men of the age. No; if its littleness is felt, a little knowledge is a very precious thing: it makes a new entrance to the mind, and through small apertures a good deal of light and sunshine can enter. So while you are endeavouring to gain a great deal of knowledge upon some particular branch of science, do not despise even a little upon other subjects which you may have neither the means nor the opportunity of following up. And I should take it as a general rule, that one cannot do better than try to make one's self completely master of that special subject which is most fully illustrated in one's own neighbourhood.

II. Never discard a specimen, however poor it may be, until you get a better : then you cannot get rid of it too quickly. A small series of really admirable specimens is more attractive than a multitude of poor ones.

III. Never allow a new specimen of anything to take its place in the collection and lose the attraction of novelty, until you have learned from it all you can. You might as well keep an old curiosity shop, as merely hoard up a quantity of specimens without taking the trouble to study and understand them. 
IV. If you have a microscope-a luxury we never attained to-you may make your observations much more profound and valuable than you possibly can otherwise. In fact, it is quite vain to expect to make any satisfactory progress without one.

V. Collect generously. Never be afraid of letting any one else have what they are really in want of to make up a set or a series, if you can spare it without absolutely injuring your collection. Remember that it is a far greater credit to you to have contributed something exceptionally fine, or it may be unique, to the National Museum, than to keep it bottled up in your own. A young man once, showing me his cabinet of fossils, drew my attention to a grand specimen of a particularly rare and beautiful fossil, and informed me, with an air of triumph, that there was nothing like it either in the British Museum or in Jermyn Street. I can only hope $I$ did not betray the contempt I felt at the meanness of spirit which could find a greater satisfaction in hoarding up such a specimen in a little unknown private collection, than in allowing the Government collectors to buy it (they always give a generous price), and place it where it would give pleasure to thousands, and be a real addition to the scientific treasures of the country. If the result of collecting is to 
beget in you a grasping, selfish spirit, you had better take your museum and throw it into the nearest pool. We may sometimes have felt a boy's foolish vanity in seeing our names upon the tablets of the British Museum as donors; but at all events, that was not so bad as gloating over a specimen and glorying in the ungenerous thought that there was not half so good a one in London.

VI. Observe accurately. Remember, collecting for the sake of having a collection is mere waste of time. The use of a collection is that it aids and illustrates observation. One new fact honestly observed and accurately recorded is worth a multitude of specimens; therefore, always be on the look out for facts. Observe accurately the minutiæ of the habits of the birds, insects, or other creatures you may come across ; mark if they correspond with what books tell you, and, if not, note the difference, and confirm your facts by repeated observations. Notice carefully the food of birds; when skinning one, open the crop, and examine minutely its contents. Everybody knows that the soft-billed birds are insectivorous, but information is much required as to the particular insects which are the favourite food of particular birds. This is a field of observation in which much still remains to be done. 
VII. Observe reverently. Cultivate a feeling of reverence for the beautiful things of this most beautiful world. Think of it as a vast temple wherein it is good to be. I well recollect once hearing that true naturalist, the late J. W. Salter, say, as he handled a group of wild flowers after a day's geologizing, "It does one good to touch them." Cultivate this reverent spirit, and you too may attain to the same exquisite sensibility to the spell which still lingers in the objects which the hand of God has planned, and the Spirit of God has breathed upon. I knew a man who used to say he could never bear to look through a microscope except upon his knees. Think of Linnæus kneeling down in admiration on seeing for the first time a common covered with Gorse in blossom!

VIII. Be careful never to let these studies which I have been recommending interfere with your duties. After all, they are only the lesser things of life-its graces and adornments-the recreations by which our powers are re-created for higher purposes; but duties are its greater things-the links which bind it to God. Don't let the hunt after a butterfly, be it the Purple Emperor himself, make you late for school, nor allow your collections to take up time which ought to be devoted to lessons. And I need hardly say, Don't let the pursuit of science in 
any form interfere with sacred things. You recollect the story of Horrocks, the wonderful mathematician and astronomer, who died when only twenty-two years old. By his own independent calculations, he had computed that the planet Venus would pass between the earth and the sun on a certain day. Such an event had never been observed by human eye. Conceive, then, the anxiety with which he must have awaited the day which would prove the accuracy of his labours, and the eagerness and impatience with which he would watch for the rising of the sun, on whose face, provided there were no flaw in his calculations, the planet would be visible as a dark spot. But it was Sunday. The following is his own account of the event:- "I observed from sunrise till nine o'clock, again a little before ten, and lastly at noon, from one to two o'clock; the rest of the day being devoted to higher studies, which might not be neglected for these pastimes." * I do not know a grander instance of the sacrifice of pleasure to duty than this.

Thus entering the great Temple of Nature with a reverent spirit, a humble and pure heart, and observant eyes, you will learn whấ no books can teach, and perceive that there is design and beauty enough to dazzle you in * See "Gallery of Nature," p. 68 . 
everything, down to the smallest insect or most insignificant weed; and so will you be enabled to comprehend the force of that profound saying of the great St. Augustine, "Not only is God in all His works, but the all of God is in eacis of His works." 


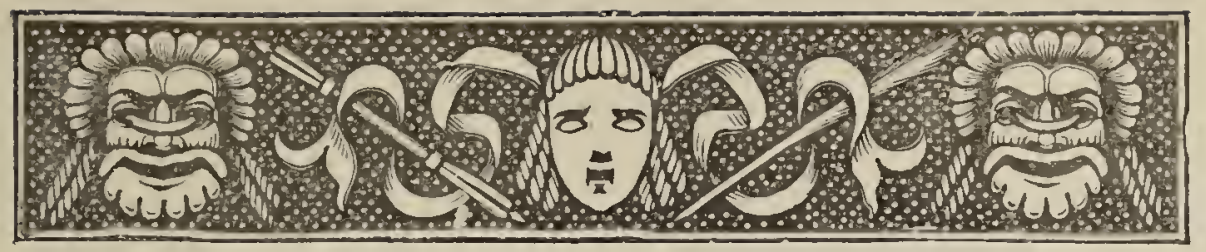

\section{APPENDIX A.}

\section{ON THE ARRANGEMENT OF NATURAL HISTORY COLLECTIONS.}

A Paper read before the West London Scientific Association.

IS THE ARRANGEMENT OF OUR NATURAL HISTORY COLLECTIONS SATISFACTORY?

THE decision which has been arrived at by Government to remove the Natural History collections from the British Museum to South Kensington offers a good opportunity for asking the question, "Is the present arrangement and display of those collections satisfactory?"

The answer will, of course, depend upon our notion of what is required of a Museum of Natural History. If we think that it has fulfilled its functions as a teacher and an educator by exhibiting so much as can be preserved of natural objects, without reference to the habits of those objects when living, or of their affinities, we rnust be prepared to answer that the present system of display leaves nothing to be desired. If, on the other hand, we have discovered that it is not only possible, but eminently practical, so to display specimens as to convey an adequate idea of their habits and surroundings in life, or of those affinities by which they are linked to other parts of creation, then I suggest that we cannot withhold the 
confession that our present system of arrangement and display is capabie of amendment to a degree almost startling to realise.

The two broad principles which I believe to be the true guides in this matter are :-

I. Specimens should be displayed so as to convey as full a conception as is practicable of the haunts and habits of the creatures exhibited, and of the circumstances under which their lives were passed. This will apply mainly to the quadrupeds, birds, and higher organisms.

II. Specimens should be displayed with the others of the same family or genus, whether now living or extinct. This will apply more especially to the shells and lower organisms.

I. Our first leading principle, then, is that objects should be exhibited so as to convey as full an idea as practicable of the haunts and habits of the creatures shown, and of the story of their lives. Just think how little we really do learn under the existing system. There, for example, we find our old friend the Sparrow. Everybody, except house-painters, loves the little cheery bird who prefers our society to the solitudes of mountain or forest, and we naturally want to learn a little about his private life and domestic arrangements. If he is a Sparrow, where is the partner of his joys? What is she like? how am I to distinguish her from her lord and master? What is the Sparrow's home like, and the Sparrow's eggs? How does the family get its living? Now, does not a Museum, as a means of education and instruction, fail if it merely gives us the Sparrow without the answer to any of these questions, or, at all events, one to be found in connection with the stuffed specimen? But lo ! there is our friend in taxidermal wretchedness, set upon such a pedestal as in life he could only have taken for some wicked trap for his feet. This, then, broadly illustrated, is the principle we must observe if specimens are to interest and instruct to the extent of which they are capable. It is not enough to set up a stuffed beast or bird. We must surround it as far as possible with the adjuncts of its natural state. 
Now, in itself, this principle is fully acknowledged, but most insufficiently carried out.

On entering the Mammal room at the top of the great staircase in the British Museum, we are at once met by a noble recognition of the principle in the group of Gorillas. How instinctively we feel that had these wonderful apes shared the fate of most of their companions in the Museum, and been simply allowed the conventional block of polished wood, the story of their lives, their fearful strength, their boundless savagery, as well as of their forest haunts, food, and manner of feeding, would have been entirely lost. Now, all is told as graphically and truthfully as could be desired.

We have read of late that of all the wonders which astonished the Shah of Persia on his visit to the Crystal Palace, none excited his admiration more than the group of two Tigers fighting. And with reason: for the animals are locked in an embrace so deadly, so desperate, so absolutely true to nature, that in them the difficult art of setting up the larger beasts does seem to have attained an excellence beyond which it will be hard indeed to pass. Now compare that group in the Palace with the specimens of the same animals in the British Museum, and you see in a moment the value of the principle which I submit must be carried out, if our Natural History specimens are to do the work of education and entertainment of which they are capable. When applied, for example, to the Squirrels, the Ant-eaters, and the Australian Platypus, how much we should then gather up, where now we pass from case to case uninstructed and unsatisfied.

On leaving the quadrupeds, we find ourselves in a long gallery devoted to birds and shells. The arrangers had doubtless a hard problem to solve when called upon to display two great collections in space quite insufficient for one ; and as it was impossible for both to have fair play, the birds had, in every sense of the phrase, to go to the wall.

How many attitudes prevail among living birds it is difficult to say; at all events two only are, as a rule, 
allowed them when stuffed, standing on curiously turned and polished pedestals, or on polished blocks-both, as all must admit, equally graceful and true to nature !

As we pass through this gallery, let us again ask ourselves the question, "Is the display of this part of our Natural History Collections satisfactory?" In other words, would it not be possible to display them so as to convey some better idea of what these birds are in life?

Now I believe that the principle already stated and considered in relation to the beasts, applies with equal force to the birds. You recollect it was this: "That objects should be exhibited so as to convey as full an idea as practicable of the haunts and habits of the creatures shown, and of the story of their lives." Let us take just three out of all the groups of birds, and notice how great is the loss occasioned by their onission. Let us look at the Swallows, the Woodpeckers, and the Humming-birds.

A. Some four or five species of Swallow annually visit our shores. Their peculiarity is that their lives in great part are spent on the wing, their feeble legs and feet presenting a striking contrast to the strength of their organs of flight.

If a person, knowing nothing of the Swallow tribe, were to go to the Museum for instruction, he would see nothing there to make him even suspect any difference between their habits and those of the Thrushes or of the Finches. There they sit in blank array, each on his several perch, from the bank-loving Sand-martin to the wonderful Swift, who, albeit he never sets foot upon ground, or tree, or housetop, is actually given a pedestal like the rest, and so is thus displayed in a position he never did occupy and never could occupy in his lifetime.

B. Well, then, let us pass on to the syivan tribe of Woodpeckers, and see how they have fared at the hands of our precious bird-stuffers. Their habits, as you know, are quite distinct from those of most other birds. They find their food, not in the air like the Swallows, nor on the ground like the Wagtails, but in the bark and decayed 
parts of trees, and search for it, clinging to the trunk. Now their construction shows very special and very beautiful adaptations to this sort of life. In order that he may gain the best possible hold, the four toes of the Woodpecker are set two in front and two behind, like the Parrot-not three in front and one behind, like most birds; so this fore-and-aft arrangement enables him to hold on with perfect security, while hammering or probing the tree for insects. But this is not all. He requires some firm support from behind while at work, and this is provided for in a tail of special construction. If it were of the same fashion as the tail of the Warbler or the Swallow, it would soon be worn down to a stump in performing an office for which it was not in the least adapted. As it is, he is furnished with a tail composed of short stiff elastic quills, and thus supported, he works away much to his own satisfaction, and the discomfiture of the various insects which infest, and, in some cases, injure the timber. Then there is another thing. Much of the prey he seeks lurks in cracks and crannies far beyond the reach of his beak, and where the insects would simply laugh at his efforts to get at them, were this beak, powerful as it is, his only weapon. All such merriment, however, is brought to a very sudden check indeed by the insertion into these harbours of a flexible clammy tongue, not unlike the proboscis of a butterfly, to which the insects stick, and are so conveyed to their assailant's crop. Now if the bird-stuffers of the Museum have resolved to suppress everything which could even suggest these peculiarities, they have been entirely successful; for, incredible as it seems, and discreditable to our scientific culture, these Woodpeckers are represented in just the same position and attitude as the Crows or the Doves. Only one is given a stick to cling to, which however he is careful not to touch with his tail. The rest sit in forlorn rows on their polished perches, suggesting falsehood by the suppression of every attitude and habit characteristic of the group.

C. The last family I shall mention, by way of illus- 
trating the importance of the principle I have stated, is that of the Humming-birds.

The habit of these living gems is strictly aerial. Around the trees and shrubs of the Western World they glance from flower to flower, with all the activity of our own Hawk-moths or Clearwings. As for sitting in the uncomfortable attitude usually assigned them by the birdstuffers, with beak painfully upraised, that the public may admire their throats, it may be true to nature, but I was never, when I was in America, fortunate enough to observe it.

These three groups, then, which I have mentioned, will be quite enough to illustrate my first principle, and to show that the mere possession of a specimen is only the first step towards conveying that instruction which we have a right to expect from our National Museum.

And if you ask, What mode of exhibition would you propose? I answer that, if I had to arrange the birds in that great Gallery, the first thing would be to remove the shells and their cabinets, and the next to take down the wall cases, to which the birds are at present condemned. I would then build up large roomy cases, on all sides of which you could walk with comfort, say one on either side of each partition of the gallery, while the central space in each might be laid out on the flower-bed principle, with cases of various sizes for the exhibition of special groups. Such cases I would then have fitted up according to the haunts of the birds to be seen. The first would naturally contain artificial rocks for the Vultures, Eagles, and some of the Falcons. Each species I would have, as far as practicable, assembled in groups-male, female, nest, and eggs. Now, as we all know, the birds are in one place, and the eggs form an exhibition by themselves in another. Birds have hearts as vell as feathers. One of the highest images of love we know of is that of a Hen gathering her chickens under her wings. Let, then, as far as possible, the birds' home-life be exhibited, for that is invariably the most touching side of bird nature.

When we come to the Swallows, it would be no hard task 
to represent them as sweeping round trees or buildings, or constructing their nests under the eaves. Each species should be seen in the attitude or at the work most characteristic of its individuality. The case for the Woodpeckers should be fitted up with stems and trunks of trees, and here the Nuthatch, Creeper, and Wryneck, as well as the Woodpecker proper, should be seen in such natural positions as would explain at once the use of the peculiar formation of their toes, tail, and tongue.

The case of Humming-birds would be very attractive. It should contain an artificial bush covered with bud and blossom, and the little creatures might be most easily arranged hovering about the flowers, while the branches would afford suitable positions for the nests.

On this principle, then, every group should be represented. The Goatsuckers should be seen sitting lengthwise on their boughs, not crosswise as at present. The Waterfowl should have something more agreeable to their feelings to stand upon than a polished board. The existing divorce between the parent birds and their nests and eggs should be annulled, and by these means the collection would assume a beauty to charm as well as a power to instruct, such as now is hardly thought possible.

The one thing required for all this is space. This, when once the collection gets to South Kensington, ought no longer to be considered as an obstacle to improvement; and it is in prospect of such removal that I have thrown out these few hints which I believe are not impracticable.

And why not apply the same plan to, at all events, some of the insects!

The present method of transfixing butterflies with a pin and sticking them in rows one after another, like policemen going on duty, should not be tolerated in great museums where there is space at command. If it is not enough to set up a stuffed bird, and say this is a Robin or Sparrow, as the case may be, without giving us an insight into its home and habits, still less is it sufficient to show us a butterfly, and say this is a Peacock or Emperor. We want to know in what form it has passed through the 
three stages of egg, caterpillar, and chrysalis, to the perfect insect. Why not, then, let us have cases of such artificial plants as the butterfly fed on in one stage or preferred in another? A few nettles and thistles would be sufficient for the Vanessa genus; here the Small Tortoise-shell might be placed on a blossom showing the upper surface of the wings, or in a position of natural rest to show the under, and not ignominiously stretched on its back, with a stake through its chest like an impaled suicide; there the eggs would be seen, and the caterpillar feeding on its accustomed food, and the chrysalis suspended in a sheltered position. Then all would be natural, beautiful, and instructive, where now all is stiff, formal, and teaching nothing. The arrangement might be extended to many groups, as, for example, the Fritillaries (Argynnidce), the Whites (Pierida), the Blues (Polyommatus), the Coppers (Lyccenas), and others. Space only is wanting, and this London is surely large enough to provide.

II. But if it is loss to exhibit birds, beasts, and insects apart from anything that tells of their habits or transformations, still greater is the loss to separate the shell-life of the present age from that of former ages. Very many of our shells belong to genera which reach back to a wonderful extent into geological time. There is no break whatever between the fossil world and the recent; and yet, as if to conceal this truth, the present creation is severed, in our greatest Museum, from the past. And here again the principle is admitted, for here and there a fossil shell is found associated with a recent, but much too timidly to assert what I conceive to be the true arrangement, that there should not be two collections of shells in the same building, the recent in this gallery, the fossil in that. Why put asunder what the Creator has joined together? Have conchological collections if you like, have geological collections if you like, but let us have one museum or one portion of a museum in which the past and present can be seen in their true relationship. As the ages succeeded one another, new types of life were introduced. Some soon fell in the great struggle for existence, some held their own 
through numberless changes, while of those which were first to appear a few have struggled on to the present hour. Is it not a study of the greatest interest to mark how it fared with these, to note how they must have adapted themselves to changes which were fatal to such as had not the same power? Think what questions as to the relation of sea and land, the atmosphere, light, climate, depth of sea, nature of sea bottom, can alone hope for an answer from noticing the changes which some families of shells exhibit, and comparing them with the habits of members of the same family still living. Why did one family perish so soon, and another, apparently weaker, last so long? Why did the Brachiopoda flourish more abundantly in the Palæozoic seas, Conchifera in the Secondary, and Gasteropoda in the Cainozoic and Recent? This one humble shell, Rhynconella, first appears in the Lower Silurians, is the prevailing form in the Upper Silurians, came to great dignity of size in the Oolitic oceans, diminished in the Tertiary, and still survives in the cold waters of Greenland. Surely we lose much by not assembling all the members of a family like this together, and regarding it in undivided unity, studying the past by the light of the present.

How instructive, too, would be a complete series of Pleurotomaria, so abundant in Palæozoic and Mesozoic seas, and of which the last surviving member seems to have died out in our own day; for so far as I know, only two or three specimens in the recent state exist, one of them being in a private collection. And in passing, let me say how unworthy, unpatriotic, and selfish it is to bottle up unique specimens in private collections. Every naturalist who has the education and instruction of the nation at heart, should look upon his collection as a feeder to the national museums, and count it his highest honour, not that he retains a unique specimen in his cabinet, but that his cabinet has contributed a unique specimen to the nation.

But to return. Of still more absorbing interest is the Lingula family. Here we see the very earliest of all known 
shells, it having been found by Dr. Hicks deep in the Menævian rocks of St. David's, and it still survives. Do we not all desire to trace the fortunes of a shell which, amid the rise and fall of countless dynasties, has so persistently held its own? 'It was already venerable in age when the great cuttle-fish of the Silurian sea made it afraid, and when the armour-clad fishes of the Devonian age brushed through the forests of its uplifted stems. It withstood the carbonladen atmosphere of the coal. It saw the greater light come forth to rule the day. It cowered beneath the overshadowing bulk of the Tanninim of the Liassic seas. It retired dismayed, not destroyed, while the diatoms and globergerinæ were raising the white cliffs of England, and reappeared with inextinguishable vitality in the Crag. And visitors to the sultry seas of the Phillipines tell us that, rooted in the mud of those Pacific waters, they can see waving to and fro in the currents large forests of this primeval mollusc, hale and hearty still, as though, having been the first of shells to appear, it had resolved to be the last to pass away!

Is it not tantalising, I say, that knowing this, and knowing the many interesting questions which arise from this, we look in vain for the complete series in any one of our national museums?

And here I will stop. Having enunciated the principles which I submit ought to be, but are not, carried out freely in our museums if they are to fulfil their object as teachers and educators, and illustrated them by many examples, the task I have set before me this evening is completed. And a pleasant task it has been, surrounded thus with the sympathy of congenial minds, to consider a subject of such national importance. It would be easy to extend these observations indefinitely. The labour has been to confine them. What I have omitted your own greater knowledge and experience will abundantly supply. I have merely suggested amendments which I believe the education of the nation requires, and the intelligence of the age demands. 


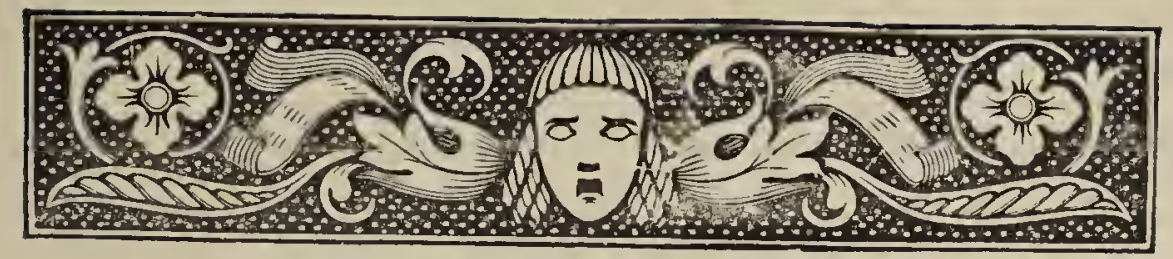

\section{APPENDIX B. \\ HOW TO COLLECT BUTTERFLIES AND MOTHS.}

By Joseph Anderson, Esq., Jun.

SUCCESS in collecting depends a great deal upon our remembering two things-when and where to go for our insects. Of course every one knows that butterflies fly by day and moths by night; but all are not aware that this knowledge is true only in part, for whilst no British butterflies are nocturnal, there are m.ny moths which are to be met with in the sunniest hours. It will be noticed that these diurnal moths rival butterflies in beauty of colour, and that in general the night moths are of sombre tints, as befitting such "children of the night." There are other moths which choose the twilight for their flight, and are named crepuscular in consequence. These belong to the Geometers, and seem to be a connecting link between butterfiies and the more characteristic moths. Amongst these may be found many lovely insects; and though the colours, except here and there, are not showy, they are exquisitely varied and blended, and the markings which adorn their wings will well repay hours of study and ohservation.

Well, now, you want to add some butterflies to your collection. Join me then in a little excursion. If in need of the Blues we must go to the downs; the Skippers we shall find in the lanes and by the roadside. You wish to get 
some Fritillaries, you say. Very good; it is July, the great month for them. Let us, then, wend our way to the nearest wood, for that is where the Silver-washed, the High-brown, and the Dark-green-three noble species - delight in disporting themselves, and we will start at once, because the morning is always the best time for butterflies. Just after noon they retire to rest till about three o'clock, hiding amongst the bushes and herbage, after which they come out again till the sun sets, though not in such numbers. To reach the wood we must go across this common. Ah! what are those glittering flashes of silver blue? See, I have one in my net-the Chalk-hill Blue. We may be pretty sure that the chalk is not far beneath the soil, as the little butterfly only frequents places where it occurs. This specimen is not in first-rate condition; it is getting late for them; so we will let it fly, and try after others. The females, you observe, are not like the males, on the upper surface the light blue colour being replaced by one of dull brown. Here is another Blue-the pretty little Silver-studded, known by the minute silver specks in the hind margin of the under side of the lower wings. These Meadow Browns and Heaths are too common for us to trouble about. We have reached the outskirts of the wood, over the hedge, and across this pasture-land. What numbers of beautiful black and white butterflies, some with a tinge of primrose yellow! These are the Marbled Whites; we must have some, as they are not to be met with everywhere. A little earlier, and we should have been certain of getting the Greasy. Fritillary, another local species.

We are now in the wood. Let us take our stand in one of these lovely glades; it is shady and very pleasant after our hot walk. Come to these brambles, where the sun shines through the trees overhead. I thought so. Look on the blossoms, at those quivering patches of burnished gold; the three sorts we want together. How lucky! Now then, strike cautiously. Ah! liot like that; the net is caught in the brambles, and away go the butterflies, laughing, it may be, at our awkwardness. They have 
settled again. Strike downzuard over the insect, which will try to fly upreards. Well done, three at one time. Do not laugh, gentle reader, or deem it improbable? What would you say, then, to netting thirteen butterflies at one stroke? and this I once had the fortune to do. We have as many Fritillaries as we want, so we will go to yon oak. Oh! see provokingly out of our reach a glorious Emperor in imperial robe of brightest purple; several more, and all too high for us to get at. What can be done? I have a piece of shining tin in my pocket. Throw it up. As I hoped, down come the pugnacious creatures to resent the intrusion upon their domains, and chase the rude intruder away. Sharp's the word and prompt the action. I have one; so have you, and yours a female, much rarer, though dressed so much more plainly. I may tell you that at Pulborough this season, nearly a dozen Emperors and Empresses were obtained in this way. Tomorrow we will come and nail to a tree a putrid carcass -cat's, dog's, or mole's-and I doubt not we shall secure many more, if the.weather continue fine.

It is a month later, and we are off for the Clouded Yellow and Sulphur. To the nearest clover-field then. From the fragrance with which "the air is lotus-laden from the perfumed breath of flowers," we cannot be far off one now, and there it is. Shall we get any to-day? I cannot say for certain; but I will tell you what I did in I 877, which will long be remembered by entomologists as the "Clouded Yellow year." The butterfly then swarmed throughout the length and breadth of the land, appearing too in places where it had never been seen before, even in the extreme north of England; and then, in one small field in the neighbourhood of Chichester, I and my brother took not only Clouded Yellows in profusion, but over forty of the white variety of the female, to which Haworth gave the name of Helice. Since that time hardly a Clouded Yellow has been seen, so irregular and uncertain are these insects in their visits.

Now we will try after some moths, and what a thing it will be if we can get them to come to us, which we may 
and will. I have prepared a mixture of sugar and beer boiled together to the consistency of treacle. A little rum may be added, and perhaps will render it more attractive; but I, as often as not, content myself with the beer and sugar only. Then I confine my sugaring to the trees surrounding our house, and am enabled to dispose of my captures readily ; otherwise, if carried some distance, I should advise the addition of the rum, as it will intoxicate the moths more speedily and effectually, and prevent them knocking about in the boxes and spoiling their appearance. I know a collector who adds, besides rum, some essence of pineapple to his preparation, making it truly delicious, and most potent and irresistible to the moth gourmands and epicures. From some mysterious cause, he finds that on occasions when he has the kind assistance of young friends the mixture disappears in a most unaccountable way. We shall want this evening plenty of chip boxes of various sizes, a lantern (not a bull's-eye), a sugaring net (which is of triangular shape, the base of the triangle being made of catgut, so that the net yields and fits round the tree trunks), a brush for the sugar, matches (always to be remembered), and we are complete. Stay ; it may be very dewy, and, walking through the herbage, our feet will get wet through, and we do not appreciate a cold, to lay us up for weeks. A pair of goloshes, and we defy the moisture.

Off we go to our wood. It is just dusk as we reach it, and the very time for applying the sugar. We choose our trees a few yards apart, avoiding all smooth trunks, which, for some inexplicable reason, do not pay, and paint the side to windward either in a broad patch or long streak, as we prefer. By the time we have made a tolerably long round it is quite dark and time to drof. in upon the company frequenting our "taverns" and enjoy. ing the nectariferous potions provided for them. Light the lantern, and give me the sugaring net. Turn the light gently on this tree, as the moths are often very skittish, and fly off immediately the light falls upon them. How 
they swarm-the moth aristocracy and ignobile vulgus, all "hail fellows well met" together! Give me a chip box, and hold the net just under that sugar patch, in case the moth should fall. I place the box beneath that glorious Crimson Under-wing : it tumbles obligingly into it, and the insect is safely boxed. And now for the next tree, and the next, till we complete our round and have obtained numbers of rare and beautiful moths. Of course such success is not always to be expected, and when the wind is in the east, or there is a very bright moon, it is of little use to go sugaring, such times apparently not falling in with moth ideas as to what constitutes good weather. Few then are to be seen about; but on a close dark night, with a gentle breeze from the south, we may count upon a good haul.

This evening we shall not sugar, and shall only require the sugaring net and a supply of chip boxes. Our mothhunting is to be conducted in the town, and we shall see the powerful attraction of light on many species of moths. The street lamps are to be our moth-traps, and will supply us, I doubt not, with many good things for our collection. Never mind the policeman-he will soon understand that we intend no mischief-or the compliments of admiring friends. As we have not a ladder, we must climb the lamp, holding on with one hand whilst we box with the other. Capital! The first lamp rewards us with a beautiful Feathered Thorn. And here is quite a rarity, a fine Plumed Prominent; both moths remarkable for their exquisitely plumose antennæ. Here is a fine Sprawler (euphonious name!), besides quite a number of common sorts. Well, that lamp yielded so well we are induced to try another.

"Gentle spring" has come, and with "ethereal mildness" too. It is a lovely night, early in April, soft and balmy as one could desire. Shall we sugar? No, it is of little use this side of June. However, I know another mode of collecting almost, if not quite, as advantageous. We shall want a large umbrella, a stout stick or two, and a lantern. During the day I have been hunting out and 
carefully marking some sallow trees (Salix caprea) in the wood. A brisk walk and we are there. The first thing is to light the lamp, and next, to open the umbrella. Hold it, please, under this sallow, laden with golden catkins. Now, shake and beat the bushes to your heart's content. A shower of catkins, leaves, spiders, earwigs ; yes, and something else, for look at these moths-they have such curious names-"Quakers" and "Hebrew Characters." And see these exceedingly pretty ones, the Pine Beauties. To-morrow we will come again, and in the autumn find out some ivy bloom, working it in the same manner.

I dare say you would like to breed some insects, bred examples being so especially bright and handsome. If you have a garden, search there first; you cannot tell what prizes may be there ready to hand. Two or three summers ago our elm trees swarmed with the caterpillars of the Large Tortoiseshell butterflies. On one small branch only, which I cut off, I counted fifty; and this year a friend and I have been round the gardens but a few times, and have taken from the apple trees more than fifty of the exquisite Eyed-hawk Moth caterpillars. You cannot fail to know this when you see it, as it has a blue horn at the end of its body. Besides these, a great prize, in the most curious and grotesque larva of the Lobster moth, rewarded our patient search. It was found feeding also upon apple. Privet Hawks, in plenty, upon privet, and some years a dozen or more of the monster Death'shead caterpillars have been secured from potatoes. Thus, you will see, even the limited space of a garden will yield numbers of insect treasures to those who will take pains to hunt for them. 


\section{NOTES ON PRESERVING LARVE.}

Make some blow-pipes of various sizes from glass tubing, the end to be melted and drawn to a fine point. Then bind two pieces of watchspring of about three inches in length to the sides, having previously heated them and bent the ends at right angles, so that they touch the tip of the pipe about a quarter of an inch from the end. A spirit lamp, tripod stand, and an oven-the latter can be easily made from a tin canister, and punching out of the lid a hole the size of a florin, and you are now set up, as far as apparatus goes. The next thing is to procure the caterpillars, and kill them in the same way as the perfect insects. When dead, take them out and place them for an hour or so in a solution of alum. Then lay theni between layers of blotting-paper, and squeeze out the contents of the body with the finger and thumb, beginning at the head, till all is forced out at the tail end. Now, just catch hold of a tiny
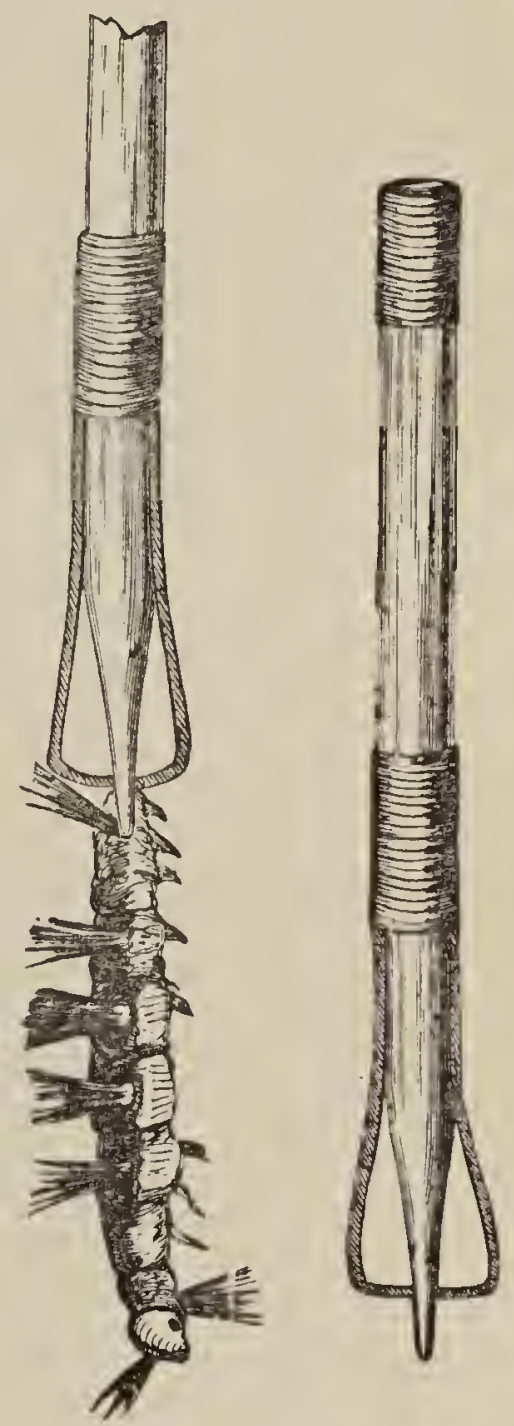
piece of the skin of the last segment, so that your caterpillar is securely fastened to the blow-pipe. Thus secured, it must be gently inflated, and kept distended whilst drying in the oven, which in the case of small specimens will occupy from one to two minutes, the heat not to be 
too great, for fear of spoiling the colour. When removed from the oven dry, the specimens are to be mounted on twigs, or on the food plant dried and preserved, or artificial flowers may be employed. For these instructions I am indebted to Mr. H. A. Auld, by whom they were furnished to the Entomologist, vol. ix. p. 8o, and previously to the pages of "Science Gossip," from which excellent periodical these illustrations are copied.

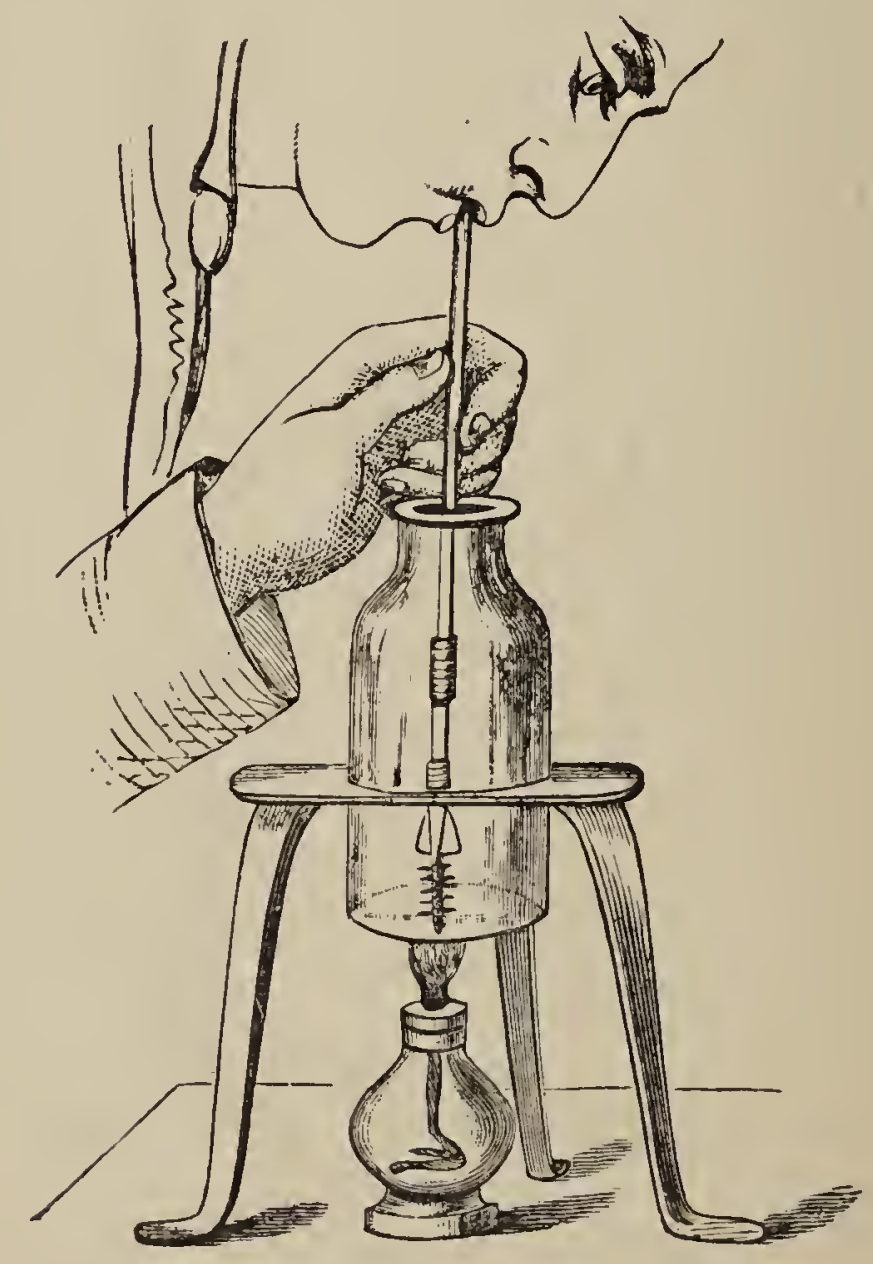




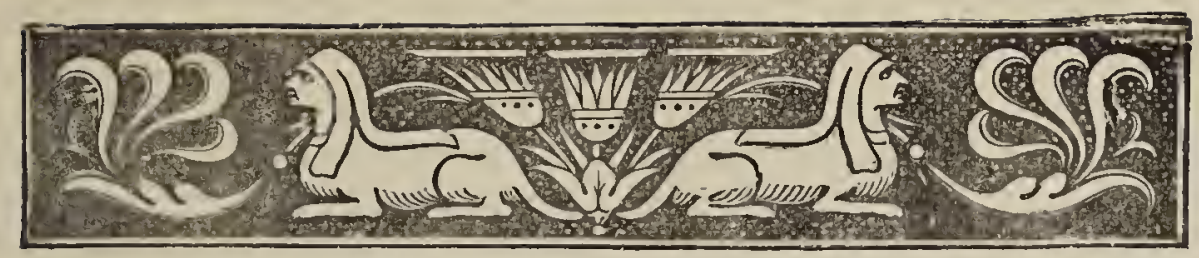

\section{N D E X.}

Accuracy in observing, 25I

Achatina acicula, I30

Acidaspis, $\mathbf{I}_{3}$

Acme, I3I

Agate-shell, I29

Agates, Brighton, r8o

Alabaster, I79

Allectus slays Carausius, 225

_- fate of, 226

Amber, I78

Amber-snail, I20

Amethyst, I8I

Ammonites of the Lias, I64

Anacharis alsinastrum, Ira

Anglo-Norman coins, portraits on, 237

Anglo-Saxon coins, 233

Anodon, IIO

Anthracite, I77

Antimony, I79

Antiquities, Roman, educational value of, 2 II

Apple-snail, I22

- mean conduct of an, I23

Aqueous rocks, I76

Aragonite, I80

Argan, proposed province of the, I46

Ark-shell, IO4

Arseniates of Cobalt, I79 of Copper, I 78

Artaxerxes butterfly, 83

Asaphus, 158

Asbestos, I82

Atcombe ponds, 22
Attitude of stuffed birds, 40, 255-259

Auger-shell, Ioo

Augite, I82

Augustine, St., on the works of God, 254

Autograph of Thomas Campbell, I94

Charles II., I87

George IJ I., 187

Mendelssolin, I94

—_ Lord Nelson, I96

- Dr. Parr, I87

- James Stanhope, I93

Autographs, educational value of, I85, 196

—_ in British Museum, I86

— of Lord Erskine, I9I

- of Sir J. Jekyll, I88

Azurite, I $^{8}$

Balia, 128

Banded Twist-shell, I26

Barbary, snails in, I32

Barytes, or Heavy Spar, I8o

Basalt, effect of its intrusion into Coal, I76

Bee Orchis, I4I

Bell-flower, good example for study, I45

Birds, list of our stuffed, 46

Birds' eggs, 50

— how to talie, 53

how to blow, 53

how to clean, 54 
Birds' eggs, how to arrange, 54 Birds' nests, interesting, 55

Birds'-nesting, delights of, 50

- not nccessarily cruel, $5 \mathrm{I}$ 52

Bird-stuffing, how learned, 36-38

- - poetry of, 40

Bismuth, I79

Blackbird, a tortured, 59

Blackcock, group of, 44

Black Oxide of Copper, I78

Black-veined White, or Hawthorn butterfly, 8I

Blood-stone, origin of the name, I8I

Bluebell, r40

Blues (Lyccence), 83, 88, 262, 266

Boat-shell, roo

Bonus Eventus, 209

Books: our, 26

- on Birds' Eggs, 55

on Botany, 153

— on British Antiquities, 2 I2

- - Birds, 49

- Fishes, 78

- on Butterflies and Moths,

91,92

- on Coins, 242

- on Crystallization, 184

on Fungi, ${ }_{52}$

on Geology, I72

on Land and Fresh-water

Shells, I34

- on Mineralogy, r84

— on Mosses, I 53

- on Sea-shells, ro7, 108

Botanical terms, not all difficult, I35, I36

Botany, why its study repels, I35

- how to begin the study, r37

Boyhood, 68

“ Boys' Own Book," 73

Brachiopoda, ro2 I70

Breccia, I77

Britain, early inhabitants of, 2ro

British coins, 217

—- Museum, autographs in, 186

r86

— pearls, Bede on, xro

Brook, lading a, 62
Brook-weed, I 40

Brown Argus, 83

Bubble-shells, I I5

Bulimus, r26

Bullfinch, difficult to skin, 37

Butterflies, fate of most collections, 79

- how to catch, 85,266

how to set, 86

how to display, $86,26 x$ old method of catching, setting, and displaying, 84

Butterflies, list of our, 89 books on, 90

Butterfly-net, how to use, 266

Cadmium, 179

Cæsar on British money, 2I9 coin of, 222

Calamine, I79

Calcite, or Calcareous Spar, I80

Calycifforæ, I44

Calymene, 163

Camberwell Beauty, its abundance in Canada, 80

Campbell, Thomas, autograph letter on his rheumatism, I94

Carausius, coin of, 223

- story of, 223

Carboniferous swamp, a, I59

- Trilobites, $16_{3}$

Carnelian, 180

Carp, strange freak of a, 72

Cassiterite, or Tin-stone, I79

Caterpillars. See Larvæ

Cefn Cave, bones from, I64

Celandine, r40

Cellar Snailet, r22

Cephalopoda, 97

Cerites, roo

Chalcedony, 180

Chalk fossils, I64

Chalk-hill Blue, 266

Charles II., signature of, I87

Chickweod Winter-green, I40

Chiton, IOI

Chlorite, 182

Chrysalis Snails, I 28

Cistus, province of the, 146

Clausitia (Close-snails), I 28

Close-snails (Clansilia), 128

Clouded Yellow, abundance in I877, 267

Coal, marvels of the, 159 
Coal, various sorts of, I77

Cochlicopa, or Zua, I29

Cockles, IO4

Coil-shells (Planorbis), I I4

Coins, how our collection of, began, 2I3

- two ways of looking at, 2I5 throw light on a disputed passage in Cæesar, 219

- sacred emblem on, 228

- why increasing in value, 24I rare, 240

Coins, books on, 242

Collecting, uses of, 25

Conchifera, I03

Conchology, 95

Cones, roo

Conglomerate, what it is, I77

Constans I., coin of, 228

Constantine the Great, coins of, 214, 227

Constantine III., story of, 229

Constantius Chlorus, coin of, 227

Copper, Glance, 178

- Native, I78

— Pyrites, I78

- Ruby, or Red Oxide of, I78

Copper butterfly, scarce, 82

Corollifloræ, I 44

Corrosive sublimate, 37

Cotswolds, the, I8

Country, dulness of the, $I_{52}$

Cowries, I00

Crane's-bill, I4I

Creeper, difficulty of skinning, 37

Crocus, I42

Cromwell, Oliver, beauty of his coins, 239

Cryptogamia, I 42

Crystallization, wonders of, 183 book on, 184

Ctenoids, 76

Cuprite, I78

Curiosities in our museum, 93

Curiosity shops, to be explored, 247

Cycladidæ, I09

curious power of the, IIO

Cyclas, IIO

how it differs from Pisidizm, I IO

Cycloids, 76

Cyclostoma, I 30

Cyphaspis, $16_{3}$
Daffudil, I fo

Daisy, I4 I

Dandelion, I4I

Death's-head moth a nuisance, 83

"Decus et tutamen," 98 note

Deiphon, I63

Delicacy of touch, 65

Dentalium, or Tooth-shell, IOI

Diøcious plants, $\mathrm{I}_{42}$

Dioptase, I8I, 247

Diorite, or Greenstone, I75

Dog's-mercury, I42

Dreissena, a usurper, II2

Dreissenidæ, I I I

Dull Snailet, I22

Dull Twist-shell, remarkable instinct of, I27

Dulness of the country, I52

Duty not to be sacrificed to pleasure, 67,253

Early Orchis, I4I

- tastes, 24

Ear-shell, or Ormer, Ioo

Edward V., groats of, $23^{3}$

Edward VI., shilling of, 239

Eels, how to hold, 62

Elegant Cyclostoma, its curious method of walking, I3I

Elephant Hawk-moth, 83

Elizabeth, Queen, lowness of relief of bust of on coins accounted for, $\Sigma 39$

Emerald, I8I

Emperor Purple, how to catch, 267

Enchanter's Nightshade, I 39

Encrinurus punctatus, $\mathrm{I}_{5} 8,16_{2}$

Endogen, section of stem, I43 leaf of, I44

Endogens and Exogens, I43

Entomological Exhibition in 1878,89

Eozoön, I 57

Epidote, I75, I82

Erskine, Lord Chancellor, auto. graph letters of, I9I

Evil of too diffuse knowledge, 248

Exchange of specimens, 246

Exogen, section of stem, I43

—_leaf of, I44 
Exogers and Endogens, I43

Eyed Hawk-moth, 83

Failures, dismal, 35, 244

Felspar, I75

Ferns, I52

Finches, group of, $4 \mathrm{I}$

Fishes, four orders of, 75

- of Woodchester, 72

- how to stuff, 74

British, books on, 78

Fishing at Shrawley and Woodchester, 60,69

Flat Coil-shell, II4

Flower, how to dissect, ${ }_{3} 38$

Flowering-rush, I40

Flowers, how to collect, I42

- how to dry and arrange, I47

list of our dried, 148

Fluor Spar, I80

Fly Orchis, I4I

Folded Close-shell, I29

Fossil and recent shells to be arranged together, 160

Fossils, why interesting, I54

two ways of arranging, 165

Fox, our unfortunate, 244

Fresh-water Shells, Io8 Limpets, I 15

Friend, a new, 64

Fritillaries, 8I

- how to group, 88

Frog-shell, Ioo

Fungi, books on, I52

Fusus, Iо0

- contrarius, $\mathrm{I}_{4}$

Galena, I79

"Gallery of Nature," what it was

to us, 26,155

— on fossils, I55

- on plants, 145

Ganoids, 76

Garden-snail, I24

Garlic Snailet, I22

Garnets, I8I

Gasteropoda, 99

Generosity in collecting, 250

Geographical distribution plants, I45

Geological periods, 156

Geology not dry, I64
Geology, books on, I72

George III., signatures of, I87

Germander Speedwell, I39

Gibraltar, flora of, I 46

Glasswort, Jointed, I39

Glassy Snail, I2I

Goatsucker, stuffed, how to place, 44

Gold sand, I79

Gorillas in British Museum, 257

Granite, I75

Grayling butterfly, 82

Greenstone, or Diorite, 175

Groats, when first coined, 238

- show no true portrait, 238

Gryphæas, I6I

Gun, importance of boys learning how to use a, 60

Gypsum, I79

Hadrian at Woodchester? 20

- coin of, 222

Hæmatite, I79

Hair-strealss, 82

Hanover coins, 239

Harold II., coins of, 233

Harp-shell, roo

Hawk-moths, 83

Hawthorn butterfly, 8I

Hayhen, the, new British bird ! 66

Hazel, I4I, I42

Heath butterflies, 82

- Snail, I25

Heaths, I40

Heavy Spar, or Barytes, I8o

Hedgehog, pleasures of stuffing, 244

Helix, I22

- hybrida, I24

Housmani, I32

Helmet-shell, roo

Henry I. penny, where found, 236

Henry VII. coins the first English shilling, 238

Henry VIII., shilling of, 239

Heulandite, 182

Hoarding valuable specimens in private collections, 263

of Homalonotus delphinocephalus, I63

Honorius grants independence to Britain, 230 
Hop, I4I

Hornblende, I82

Horny Coil-shell, II 4

Horrocks the astronomer, a story of, 253

Horse-chestnut, I40

Hospitality, rustic, 23

Hugh Miller on the order of the introduction of fishes, 77

Humming-birds, how to display, $26 I$

Humming-bird Hawk-moth, 83

Hydrous Silicates, 182

- Sulphate of Lime, I82

Ichthyosaurus, I6I

Igneous rocks, 175

Illanus, 163

Iron ore, Pisolitic, I79

- - Red, or Hæmatite,

$$
\text { I79 }
$$

Iron-Stone, I79

Jack, taught experience by a, 70

- an invalid, 7 I

Jasper, I8I

Jekyll, Sir J., autograph poems, I88-I90

Jet, 177

Kaoline, I75

Kentish Snail, I24

Kestrel, shooting a, 42

Kestrels, group of, 4I

Kingfishor's nest, 54

Knowledge, a little, not necessarily a dangerous thing, 248

\section{7}

Labiates at Gibraltar, I46

Labrador, or Refracting, Spar, I8I

Lachrymatory, Roman, 2II

Lading a brcok, fun of, 62

Lady's-slipper, I4I

Laminated Close-snail, I29

Lamps, street, moths in, 269

Land-shells, ir8

- interest of, $\mathrm{I}_{32}$

list of, in our museum, 133

Lapis-lazuli, I8I
Larvæ, how to collect, 270

- notes on preserving, 27I

Lead, I79

- Sulphide of, or Galena, I79

Red Oxide of, or Minium,

I79

Lias, monsters of the, $16 \mathrm{I}$

Lignite, I64, I77

Lime Hawk-moth, 83

Limestones, $\mathrm{I} 77$

Limpets, I00

fresh-water, II 5

Lingula, 103,263

rast antiquity and geological history of, 166

Linnæan system of botany, advantages of, 137,145

List of our Birds and Eggs, 46 Recent and Fossil Brachio-

poda, I70

Butterflies, 89

Dried Fowers, I48

- Fishes, 78

- Fresh-water Shells, II6

Land-shells, I33

- Moths, 9 I

Lysons, excavations of, at Woodchester, 203

Mactra, IO4

Madrepores, I8 I

Magnentius, coin of, 229

Magnetic Iron ore, 179

Magnus Maximus, story of, 229

Malachite, $\mathbf{I}_{7} 8$

Manganese, 179

Marathon, arrow-heads from, 94

Marble, I76

Mare's-tail, I39, I42

Margined Chrysalis Snail, I28

Marsh-shell, Common, II3

Mary I., groat of, 239

Mediterranean flora, character of, 146

Melanice, roo

Mendelssohn, scrap of writing of, 195

Mesozoic period, I60, I64

Metamorphic rocks, I76

Mica, 182

Microscope, value of the, 250

Mineralogy, books on, I84

Minerals, lessons taught by, I83

— their interest, I73 
Minimi, 23I

Minium, or Red Oxide of Lead, I79

Mitre-shells, roo

Mollusca, how classified, 96

Money Cowry, Ioo

Monochlamydeæ, I44.

Monœecious plants, I42

Moss-shell, 128

Mosses, I 52

Mountain Twist-shell, I26

Mummy, wheat, and bread, 93

Murex, too

Museum, our, its beginnings, 24,

$243-$ described, 28
24 I, 245
-
British, on the arrangement
of Natural History specimens
in, 255
I86 courtesy of officials of,

Natica, Ioo

Natural system of botany, I 43

Naturalists' shops recommended, 9r

Needle Agate-shell, found in human bones, I 30

Nelson, Lord, part of an autograph letter, Ig6

Nerite, River, II3

Nests, interesting, 4I, 54

New British bird! 66

New Snail, I 32

Nineveh, seal from, 94

Obsidian, I8I

Octopus, adventure with an, 98

Offa, beauty of his coins, accounted for, 232

Oldhamia antiqua, I57

Olive-shells, Ioo

Olivenite, 178

Operculated Land-shells, I30

Orange-tip, 8I

Owl, difficult to skin? $3^{8}$

Painted Lady, 82

Palreozoic fossils, $\mathrm{x} 57, \mathrm{x} 62$

Paludina, II 3

Papilionaceous plants, I4I
Paradoxides, I 57, I62

Parliamentary orators, scale of, I9I

Parr, Dr., on the use of Quando, I87

Pax, meaning of, on coins, 234

Pea-shell (Pisidium), IIo

Peacock-coal, I77

Pearl-oyster, I04

Pearls, British, I Io

Pectens, IO4

Pelargonium, I4I

Penny, when first coined, 232

Perch, catching a large, 72

Petrolcum, I77

Phacops, 163

Philip and Mary, shilling of, 239

Pholas, I0.4

Phosphates of Copper, I78

Pinnæ, pair of gloves made fronı the byssus of, IO4

Pisidium (Pea-shell), how it differs from Cyclas, IIo

Pisolitic Iron ore, I79

Placoids, 75

Planorbis, II 4

Platinum, I79

Plesiosaurus, I6I

Pleurotomaria, almost or quite extinct, Ioo

Polecat, delights of stuffing a, 244

Poplar Hawk-moth, 83

Porphyry, I7 5

Postage stamps, educational value of, 200

— introduction of, 199

- how to arrange, I99

Prehistoric flint instruments, I64

Pretty, or White Snail, I25

Primrose, I40

- dissected, I38

Privet, I 39

- Hawk-moth, 83

Pterodactyl, I6I

Pteropoda, IoI

- Dr. Woodward on, IoI

Pudding-stone, I77

Puimoniferce, II 4

Pupa, I28

Purple Emperor, 8I, 267

Loosestrife, I 40

Purples (Purpurce), Ioo 


\section{INDEX.}

Pygmy Snail, I25

Pyranid-shells, Ioo

Quando, Dr. Parr un, I87

Quartz, various sorts, 180

Ragged Robin, I40

Razor-shell, I04

Red crag, shells of the, 164

Red Iron ore (Hamatite), I79

Reverence in observing, 252

Rhynconella, geological history of, 167

- psittacea, I68

Richard I., penny of, 237

Richard II. and III., searcity of groats of, 238

Rock Crystal, I74

— Snail, I26

- specimens, $\mathbf{1} 78$

Rodborough, vale of, I8

Roman antiquities, 20r, 209

-__ villas, sites of, 201

——at Woodchester, 20I

—- site of, I9

- - description of, 204

- mosaic pavements, 207

Round-spired Coil-shell, II4

Sandstones, I77

Satin Spar, I80

Sceattas, Anglo-Saxon, 232

Scorpion-shell, roo

Sea-shells, 93

Seal from Nineveh, 94

Selenite, I80

Seraphs, 99

Serpentine, I75

Severus, coin of, 223

Sharks' teeth from London clay, I64

Shells, qualified interest of, in themselves, 95

- value of the study of, I05

- land, II8

- fresh-water, II5

- how to display, II5, 262

- list of, in our museum, Ir6

Shelsley Hill, 2I, 82

Shrawley, fishing at, 60

Grove, 61

Wood, 56 butterflies of, 63
Silver, Native, I79

Skippers, 82, 255

Slugs, I 18

Snail-hunting, I08

Common, 123

Snailets (Helicella), I22

Snails (Helix), I22

- classification of, I09, I20 in Barbary, 132

Specimens, how to display, $2 j 6$

_ to be studied as soon as obtained, 249

- what to keep, 249

Sphcerexochus mirus, $\mathrm{I}_{3}$

Spindle-shell, Ioo

St. John's-wort, I4I

St. Paul at Woodchester? 20

Stalactite and Stalagmite, I8o

Stanhope, James, autograph letter of, I93

"Stank," a good local word, 62

Starling, difficulty of getting his favourite food, I29

Steatite, or Soap-stone, 182

Steel traps, cruelty of, $5^{8}$

Stephen, pennies of, 237

Stream Bubble-shell, II5

Strombs, 99

Stroud, 18

Stuart coins, 239

Stuffed birds, attitude of, 40, 4.5 . $257,258,260$

Stycas, 232

Sugaring for moths, 2.68

Sulphur, Native, I79

Swallow-tail, 80

- Scarce, 80

Sweet-pea, I4I

Syenite, 175

Talc, 182

Taxidermy, difficulties of, 35

Tellens, I04

Tennantite, I78

Tentacled Bithinia, II4

Terebratula, geological history of, 168

- caput-serpentis, 169

- grandis, 168

Tertiary period, climate of, $\mathrm{I} 62$

- - fossils, $\mathrm{r} 64$

Testacella, character of, cleared, II9

Thalamiforæ, I44 
Tin, crystals of, Pyrites, Tinstone, I79

Tinez and Tortrices, 89

Titmice, group of, 4I

Tooth-shells (Dentalium), ror

Top-shells, roo

Topaz, I8I

Travel, pleasures of, how increased, 26

Trilobites, 157,162

Trinucleus concentricus, $\mathrm{I} 62$

Trochi, or Hoop-shells, roo

Tudor coins, 238

Tunicata, ro5

Turritellæ, roo

Tyrants, the thirty, coins of, 223

Umbilicated Chrysalis Snail, I28

Unio, I Io

Uses of collecting, 25

Valvatida, or Valve-shells, II4

Vanessa, group of, 8I

Varnished Shell, I29

Vegetable ivory, 94

Venus-shells, I04

Vertigo, 128

Vetch, I4I

Victoria, Gothic crown, 240

Violet-shells, roo

Virgil, the nightingale's lament, 52

Virina, I2I

Volutes, Ioo
Wall-cases bad for stuffed birds, 46

Wall-flower, 140

Walton's "Angler," 26

Wandering Mud-shell, II5

Waterton's works, 26

Well-trap in Shrawley Wood, 57

Whelks, I0o

White Admiral, 8I

- Dead-nettle, I40

White's "Selborne," 26

Whorl-snails (Vertigo), I28

Wild Rose, I40

Wilkes, John, autograph letter of, I88

William I. and II., portraits on coins of, 237

Willow-herb, I 40

Woodpecker, stuffed, attitude of, $25^{8}$

Wood-pigeon, stuffing a, 3I

Wood-ruff, I40

Wood-snail, I24

Woodward's "Manual of the Mollusca," 27, 94, 96, 107

Wood White, 8I

Wrinkled Close-snail, I29

Yellow Flag, I39

Zinc-blende, I79

Zinc, Carbonate of, I79

Zoned Snail, I24

Zua, or Cochlicopa, I29

THE END. 


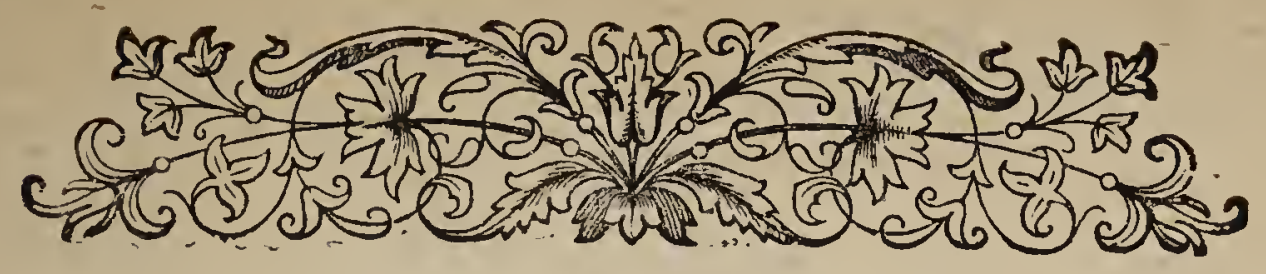

\section{PUBLICATIONS}

OF THE

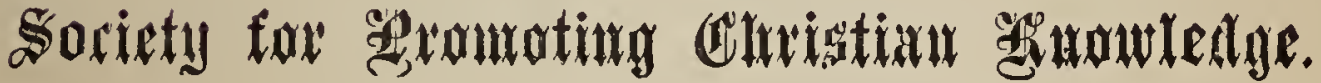

A "LEAL LIGHT HEART." By AnnetTe Lyster, author s. d. of " Northwind and Sunshine," \&c. With Four page Illustrations. Crown 8vo. .....................Cloth boards

A LITTLE CAPTIVE MAID. With Three page Illustrations. Crown 8vo. ............................... Cloth boards

a MEssage FROM THe SEA. By A. Eubule-Evans. With Three page Illustrations. Crown 8vo. Cloth boards

A PROMising BOY. By Annette Lyster. With Three page Illustrations. Crown 8vo.................Cloth boards

ADVENTUROUS VOYAGE OF TEE " POLLY," AND OTHER

YARNS (THE). By the late S. W. SADLER, R.N. With Three page Illustrations. Crown 8 ro. Cloth boards

ALONE AMONG THE ZULUS. By a Plain Woman. The Narrative of a Journey through the Zulu Country. With Four page Illustrations. Crown 8 vo....... Cloth boards

ANIMAL CREATION (THE). A Popular Introduction to Zoology. By Thomas Rymer Jones, Esq. With nearly 500 Engravings. Post 8vo............ Cloth boards 76 
ANOTHER MAN'S BORDEN. A Tale of Love and Duty.

By Austin ClaRe. With Four page Illustrations. Crown 8vo.......................................Cloth,boards

AUNT KEZIA'S WILL. By S. M. SitwelL, author of "The Andrews Family," \&c. With Three page Illustra. tions. Crown 8vo. ...........................Cloth boards

AUSTRALIA'S HEROES : being a slight Sketch of the most prominent amongst the band of gallant Men who devoted their lives and energies to the cause of Science and the development of the Fifth Continent. By C. H. EDEN, Esq. With Map. Crown 8vo.......Cloth boards

BELFRY OF ST. JUDE (THE). A Story. By EsMÉ STUART, author of "Mimi." With Three page Illustrations. Crown 8vo. ..........................Cloth boards

BIBLE PLACES; or, The Topography of the Holy Land. By the Rev. Canon Tristram. With Map. Post 8vo. Cloth boards

BRAVE MEN OF EYAM (THE); or, A Tale of the Great Plague Year. By the Rev. E. N. HOARE, M.A., author of "Two Voyages," \&c. With Three page Illustrations. Crown 8vo. .................... Cloth boards

BRITISH BIRDS IN THEIR HAUNTS: being a Popular Account of the Birds which have been observed in the British Isles, their Haunts and Habits. By the late Rev. C. A. Johns, B.A., F.L.S. Post 8vo. Cloth boards

CAPTAIN JAPP; or, The Strange Adventures of Willie Gordon. By Gordon Stables, C.M., M.D., R.N. With Five page Illustrations. Crown 8vo. Cloth boards

CHEMISTRY OF CREATION (THE) : being a Sketch of the chief Chemical and Physical Phenomena of Earth, Air, and Ocean. By Robert Ellis, M.R.C.S. A new edition, revised by Professor Bernays, F.C.S., \&c. With numerous Illustrations. Fcap. 8vo....Cloth board's

CHINA. By Professor R. K. Douglas, of the British Museum. With Map and Eight page Illustrations and several smaller Woodcuts, Post 8vo, ......Cloth boards 
CHRISTIANS ONDER THE CRESCENT IN ASIA. By the s. 2

Rev. Edward L. CutTs, B.A., author of "Turning Points of Church History," \&c. With numerous Illustrations. Post 8 vo. .............................Cloth boards

CHRISTOPHER. By HeLen SHipton. With Four page Illustrations. Crown 8vo.....................Cloth boards

CHRYSSIE'S HERO. By ANNETTE LYSTER, author of "Fan's Silken String," \&c. With Three page Illustrations. Crown 8vo. .............................Cloth boards

CICELY'S MISTAKE. The Story of a Lost Treasure. By A. Eubule-Evans. With Three page Illustrations. Crown 8vo.........................................Cloth boards

CROWN AND SCEPTRE: a West Country Story. By G. Manville FenN. With Five page Illustrations. Crown 8vo...................................... Cloth boards

DICK DARLINGTON, at Home and Abroad. By A. H. ENGELBACH. With Three page Illustrations. Crown 8vo. ................................................Cloth boards

EVENINGS AT THE MICROSCOPE; or, Researches among the Minuter Organs and Forms of Animal Life. By the late P. H. Gosse, Esq., F.R.S. Post 8vo. Cloth boards EVERYDAY HEROES. Stories of Bravery during the Queen's Reign, 1837-I888. With numerous Woodcuts.

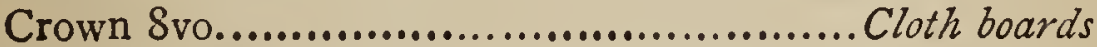

FIFTH CONTINENT, WITH THE ADJACENT ISLANDS (THE): being an account of Australia, Tasmania, and New Guinea, with Statistical Information to the latest date. By C. H. Eden, Esq. With Map. Crown 8vo. Cloth boards

FISHES, NATORAL HISTORY OF BRITISH: their Structure, Economic Uses, and Capture by Net and Rod. By the late FrANK BUCKLAND. With numerous Woodcuts. Crown 8vo. .......................Cloth boards

FLOWERS OF THE FIELD. By the late Rev. C. A. Johns, F.L.S. A New Edition, with Appendix on Grasses, by C. H. JoHss, Esq. With numerous Woodcuts. Fcap. 8vo. Cloth boards 
FOREST TREES. By the late Rev. C. A. Johns. With numerous Woodcuts. Post 8vo................Cloth boards

FREAKS AND MARVELS OF PLANT LIFE; or, Curiosities of Vegetation. By M. C. Cooke, M.A., LL.D. With numerous Illustrations. Post 8 vo..............Cloth boards

FROZEN ASIA. A Sketch of Modern Siberia. Together with an account of the Native Tribes inhabiting that Region. By C. H. EdeN, Esq., F.R.G.S. With Map. Crown 8vo.... ..................................Cloth boards

GIL THE GONNER; or, The Youngest Officer in the East. By G. Manville Fenn. With Five page Illustrations. Crown 8vo. .................................... Cloth boards

GREAT-UNCLE HOOT-TOOT. By Mrs. MOLESWORTH, author of "Carrots." With numerous Illustrations. Small 4to. ......................................Cloth boards

HARRY WILDE. A Tale of the Brine and the Breeze. By Gordon Stables, C.M., R.N. With Four page Illustrations. Crown 8vo. .................... Cloth boards

HASSELAERS (THE.) A Tale of Courage and Endurance. By Mrs. Frank Cooper. With Three page Illustrations. Crown 8vo. .............................Cloth boards

HER FATHER'S INHERITANCE. By CRONA TEMPLE, author of "Through the Rough Wind," \&c. With Four page Illustrations. Crown 8vo. ...... Cloth boards

HEROES OF THE ARCTIC AND THEIR ADVENTURES (THE.) By Frederick Whymper, Esq. With Map, Eight page Woodcuts, and numerous smaller Engravings. Crown 8vo................................Cloth boards

HISTORY OF INDIA, from the Earliest Times to the Present Day. By L. J. Trotter. With a Map and Twenty-three Engravings. Post 8vo.........Cloth boards

JEWISH NATION (A HISTORY OF THE), from the Earliest Times to the Present Day. By the late E. H. Palmer, M.A. With Map of Palestine, and numerous Illustrations. Crown 8 vo. Cloth boards 
RATE, THE PRIDE OF THE PARISH. By ELIZABETH

HARCOURT Mitchell, author of "Engel the Fearless."

With Three page Illustrations. Crown 8vo... Cloth bds.

RING'S MARDEN. By the author of "Our Valley," \&c. With Four page Illustrations. Crown 8vo.... Cloth $b d s$.

LAND OF ISRAEL (THF). A Journal of Travels in Palestine, undertaken with special reference to its Physical Character. By the Rev. Canon Tristram. With Two Maps, Four page Coloured Plates, Eight page Illustrations, and numerous other Engravings. Large post 8 vo. Cloth boards 10

MARCEL'S DUTY. A Story of War-Time. By MARY E. PALGRAVE, author of "John Holbrook's Lessons." With Three page Illustrations. Crown 8 vo... Cloth bds.

MASS' GEORGE; or, A Boy's Adventures in the Old Savannahs. By G. MANville Fenn. With Five page Illustrations. Crown 8vo................... Cloth boards

MATE OF THE "LILY" (THE); or, Notes from Harry Musgrave's Log-book. By the late William H. G. KIngston. With Three page Illustrations, Crown 8 vo. Cloth boards

MIKE. A Tale of the Great Irish Famine. By the author of "Between the Locks," \&c. With Three page Illustrations. Crown 8vo. .........................Cloth boards

MIMI. A Story of Peasant Life in Normandy. By Esmé STUART, author of "The Little Brown Girl." With Three page Illustrations. Crown 8vo...... Cloth boards

MISCELLANIES OF ANIMAL LIFE. By ELIZABETH SPOONER, author of "Daily Readings for a Year," \&c. With Illustrations. Post Svo..................Cloth boards

MISSY AND MASTER. By M. BRAMSTON, author of "The Snowball Society," \&c. With Three page Illustrations. Crown 8 vo...... ... .ar.......................... Cloth boards

MRS. DOBBS' DULL BOY. By ANNETTE LySTER, author of "Northwind and Sunshine," \&c. With Three page Illustrations. Crown 8vo, ....................Cloth boards 
NATURAL HISTORY OF THE BIBLE. By the Rev. Canon TRISTRAM, author of "The Land of Israel," \&c. With numerous Illustrations. Post 8 vo. ...Cloth boards

NOT A SUCCESS. By the author of "Our Valley," "The Children of Seeligsberg," \&c. With Three page Illustrations. Crown 8vo. .......................... Cloth boards

OCEAN (THE). By the late P. H. Gosse, F.R.S. With Fifty-one Illustrations. Post 8vo.............Cloth boards

OUR NATIVE SONGSTERS. By ANNe PRATT. With Seventy-two Coloured Plates. I6mo. ...... Cloth boards 4 o

PERCY TREVOR'S TRAINING. By the Rev. E. N. HOARE, author of "Two Voyages," \&c. With Three page Illustrations. Crown 8vo. ............. Cloth boards

PHILIP VANDELEUR'S VICTORY. By C. H. EDEN, author of "Australia's Heroes," \&c. With Three page Illustrations. Crown 8vo.................... Cloth board's

RICK RALTON'S RECONCILIATION. By the Rev. E. N. HOARE, M.A. With Four page Illustrations. Crown 8vo. ..............................................Cloth boards

ROBINSON CRUSOE (THE IIFE AND SURPRISING ADVENTURES OF.) With Five page Illustrations and several smaller Woodcuts. Post 8vo.......... Cloth board's

RUSSIA, PAST AND PRESENT. Adapted from the German of Lankenau and Oelnitz. By Mrs. Chester. With Map and Three page Woodcuts and Vignettes. Post 8vo.........................................Cloth boards

SAIL Ho! or, a Boy at Sea. By G. Manville Fenn. With Five page Illustrations. Crown 8vo. Cloth boards 5 o

SAILING AND SEALING. A Tale of the North Pacific. By F. Franikfort Moore. With Four page Illustrations. Crown 8vo. .............................Cloth boards

SECOND SIGHT. By A. Eubule-Evans. With Three page Illustrations. Crown 8 vo. Cloth boards 
FOR PROMOTING CHRISTIAN KNOWLEDGE.

SLAVER OF ZANZIBAR (THE). BY F. FRANKFORT s. $d$.

MOoRe. With Four page Illustrations. Crown 8vo. Cloth boards

SLAVERS AND CRUISERS. By the late S. W. SAdLER, R.N., author of "Marshall Vavasour," "The Slave Dealer," \&c. With Four page Illustrations. Crown 8 vo. Cloth boards

SOME HEROES OF TRAVEL; or, Chapters from the History of Geographical Discovery and Enterprise. Compiled and rewritten by the late W. H. DAvenpor'T AdAMs. With Map. Crown 8vo. ......... Cloth boards

SPITEWINTER. By Helen Shipton. With Three page Woodcuts. Crown 8vo. ......................Cloth boards

SQUIRE OF BRATTON (THE). By the author of "The Dean's Little Daughter." With Three page Illustrations. Crown 8 vo......................................Cloth boards

ST. ANNE'S COURT. By C. E. M., author of "Adam Gorlake's Will." With Four page Illustrations. Crown 8vo. ...............................................Cloth boards

STORIES FROM ITALIAN HISTORY. By the late B. Montgomerie Ranking. With Two page Illustrations. Crown 8 vo..............................Cloth boards

SWEET WILlIAM. By Mrs. Thomas ERskine. With Three page Illustrations. Crown 8vo. ...... Cloth boards

THREE MARTYRS OF THE NINETEENTH CENTURY. Studies from the Lives of Livingstone, Gordon, and Patteson. By Mrs. Rundle Charles, Crown 8vo. Cloth boards

THROUGH THE ROUGH WIND. A Story of the Collieries. By Crona Temple, author of "Etta's Fairies," \&c. With Three page Illustrations. Crown 8vo. Cloth boards

TO The West. By G. Manville Fenn. With Five page Illustrations. Crown 8vo. ...............Cloth boards 
TWO CLIPPERS (THE). By F. FRANKForT MOORE. With Four page Illustrations. Crown 8vo. Cloth boards. 36

"TWO FRIENDS AND A FIDDLE." By Helen SHIPTON. With Five page Illustrations. Crown 8vo. Cloth boards s. $d$. 50

ONTO HIS LIFE'S END. A Book for Choir-Boys. By URsula, author of "Little Things," \&c. With Three page Illustrations. Crown 8 vo. Cloth boards

UNDER THE TREES. By H. L. ChILdE-PEMBERTON, author of "Round My Table." With Three page Illustrations. Crown 8vo. .................... Cloth boards

UNSETTLED FOR LIFE; or, What shall I be? By the Rev. Harry Jones, M.A. Crown 8vo. ... Cloth boards 26

VAST ABYSS (THE). By G. MANville FenN. With Five page Illustrations. Crown 8 vo................ Cloth boards

WHITE CHAPEL (THE). A Story. By Esmé STUART, author of "Mimi," \&c. With Three page Illustrations Crown 8 vo.......................................Cloth boards

WHITE GIPSY (THE). By ANNETTE LYSTER. With Four page Illustrations. Crown 8vo..........Cloth boards

WITCH'S DEN (THE). By PHœBE AlLEN. With Three page Illustrations. Crown 8vo............... Cloth boards

WRECKED LIVES; or, Men who have Failed. First and Second Series. By the late W. H. DAvenPorT ADAms. Crown 8vo. ............ Cloth boards, each series 



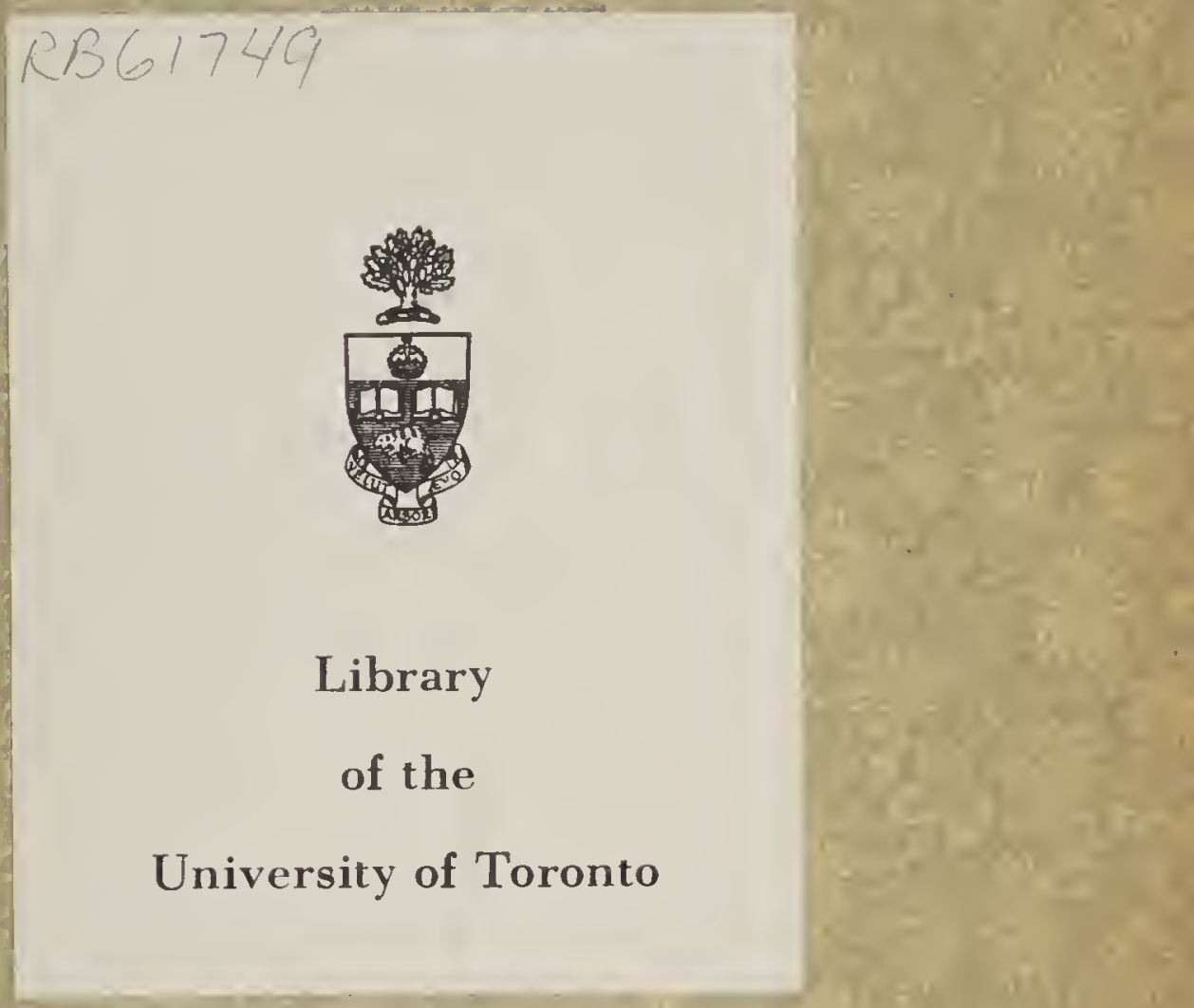
